\title{
ISSN 2226-3365
}

www.vestnik.nspu.ru

DOI: 10.15293/2226-3365.1405

\section{$\mathscr{B E} C \mathscr{T H} \mathcal{H} \mathcal{K}$}

Новосибирского государственного педагогического университета

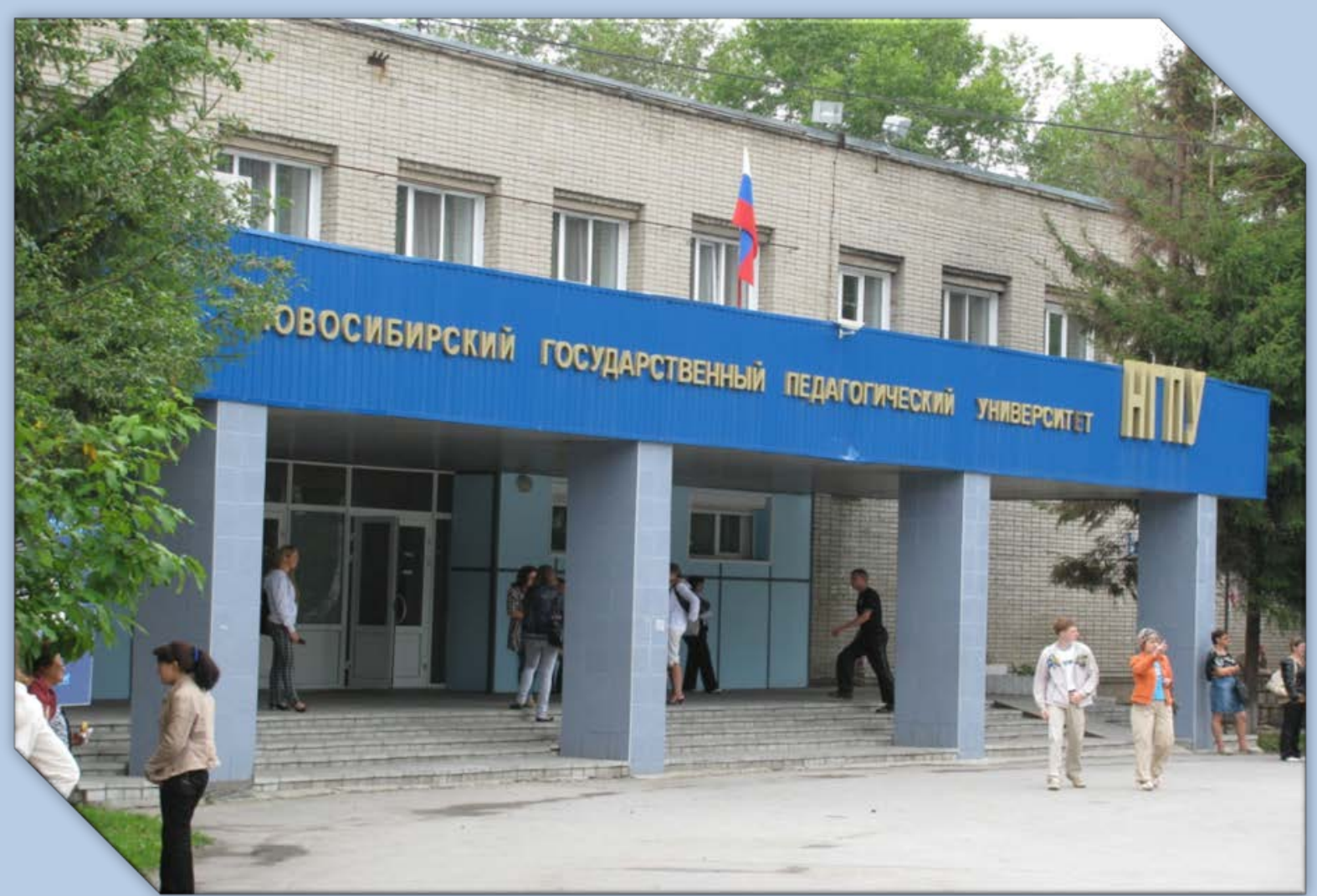

Novosibirsk State

Pedagogical University

$$
\begin{aligned}
& \text { BULLETIN } \\
& \text { 5(21) } 2014
\end{aligned}
$$


Учредитель журнала:

ФГБОУ ВПО «Новосибирский государственный педагогический университет»
Электронный журнал «Вестник Новосибирского государственного педагогического университета» зарегистрирован Федеральной службой по надзору в сфере связи, информационных технологий и массовых коммуникаций (Роскомнадзор)

ЭЛ № ФС77-50014

\section{РЕДАКЦИОННАЯ КОЛЛЕГИЯ И СОВЕТ НАУЧНОГО ЭЛЕКТРОННОГО ЖУРНАЛА «ВЕСТНИК НОВОСИБИРСКОГО ГОСУДАРСТВЕННОГО ПЕДАГОГИЧЕСКОГО УНИВЕРСИТЕТА»}

\section{Редакционная коллегия}

главный редактор

Пушкарёва Е. А., д-р филос. наук, проф. заместитель главного редактора Майер Б. О., д-р филос. наук, проф.

педагогические и психологические науки Синенко В.Я., д-р пед. наук, профессор Богомаз С. А., д-р психол. наук, проф. (Томск) философские и гуманитарные науки Майер Б. О., д-р. филос. наук, проф. Зверев В. А., д-р ист. наук, проф. науки о земле; физико-математические и технические науки

Трофимов В. М., д-р физ.-мат. наук, проф. социильно-экономические науки

Ряписов Н. А., д-р экон. наук, проф., биологические, химические, медицинские науки Айзман Р. И., д-р биол. наук, проф., член-корр. МАНВШ, заслуж. деят. науки РФ

Просенко А. Е., д-р хим. наук, проф. культурология и искусствоведение

Чапля Т. В., д-р культурологии, проф. филологические науки

Трипольская Т. А., Д-р. филолог. наук, проф.

\section{Международный редакционный совет}

Айзман О., д-р филос., д-р мед., Каролинский институт (Стокгольм, Швеция)

Ангелика Ригер, д-р, проф. (Ахен, Германия) Анна Паола Бонола, проф. славистики, Миланский университет (Милан, Италия) Балгимбеков Ш.А., д-р мед. наук, проф, (Алматы, Казахстан)

Бухтова Б., д-р наук, Университет им. Масарика (Брно, Чехия)

Валькенхорст Ф., д-р наук, проф., университет Кельна (Кельн, Германия)

Винго Чарльз С., д-р мед. наук, проф., ун-т Флориды (Гейнсвилль, Флорида, США) Либерска Х. д-р психол. наук, проф., ун-т им. Казимира Великого (Быдгощ, Польша) Логунов Д., н.с., ун-т Манчестера (Великобритания)

Мауриция Калузио, д-р наук, ст. исследов. по русс. лит. (Милан, Италия)

Мукатаева Ж.М., д-р биол. наук (Павлодар, Казахстан)

Чагин А., д-р филос., н. с., Каролинский институт (Стокгольм, Швеция)

Челси Д., Д-р филос., проф., (Уппсала, Швеция) Шмайс Й., Д-р наук, Университет им. Масарика (Брно, Чехия)

Юй Вень Ли, д-р политического образования, Пекинский университет (Пекин, Китай)

\section{Редакционный совет}

председатель редакиионного совета

Герасёв А. Д., д-р биол. наук, проф. (Новосибирск)

Афтанас Л.И., д-р мед. наук, проф., акад. РАМН, вицепрезидент РАМН, Президент СО РАМН (Новосибирск) Баликоев В.3., д-р экон. наук, проф. (Новосибирск) Безруких М.М., Д-р биол. наук, проф., почетный профессор НГПУ, академик РАО (Москва)

Бережнова Е.В., д-р пед. наук, проф. (Москва) Винокуров Ю.И., д-р геогр. наук, проф. (Барнаул) Галажинский Э.В., д-р психол. наук, проф., академик РАО (Томск)

Дымарский М. Я., Д-р филолог. наук, проф. (СанктПетербург)

Жафяров А.Ж., д-р физ.-мат. наук, проф., член.-корр. РАО (Новосибирск)

Жукоцкая 3.Р., д-р культурол., проф. (Нижневартовск)

Иванова Л.Н., д-р мед. наук, проф., акад. РАН

(Новосибирск)

Казин Э.М., д-р биол. наук, проф., заслуж. деят. науки РФ, академик МАНВШ (Кемерово)

Клочко В.Е., Д-р психол. наук, проф. (Томск)

Князев Н.А., д-р филос. наук, проф. (Красноярск)

Кондаков И.В., д-р филос. наук, проф., акад. РАЕН, почетный работник общего образования (Москва) Краснорядцева О.М., д-р психол. наук, проф. (Томск) Кривощеков С.Г., д-р мед. наук, проф. (Новосибирск) Кудашов В.И., д-р филос. наук, проф. (Красноярск) Кустова Г.И., д-р филолог. наук, проф. (Москва) Медведев М.А., д-р мед. наук, проф., академик РАМН, заслуж. деят. науки РФ (Томск)

Мокрецова Л.А., д-р пед. наук, проф. (Бийск)

Овчинников Ю.Э., д-р физ.-мат. наук, проф.

(Новосибирск)

Печерская Т.И., д-р филолог. наук, проф.

(Новосибирск)

Пузырев В.П., д-р мед. наук, проф., академик РАМН

(Томск)

Серый А.В., д-р психол. наук, проф. (Кемерово)

Федоров В.И., д-р биол. наук, проф. (Новосибирск)

Чупахин Н.П., д-р филос. наук, проф. (Томск)

Шошенко К.А., Д-р мед. наук, проф. (Новосибирск)

Основан в 2011 году, выходит 6 раз в год

Редакционно-издательский отдел: 630126, г. Новосибирск, ул. Вилюйская, д. 28 тел. +7(383)244-34-50

E-mail: vestnik.nspu@gmail.ru 


\section{EDITORIAL BOARD AND EDITORIAL COUNCIL OF SCIENTIFIC ELECTRONIC JOURNAL «NOVOSIBIRSK STATE PEDAGOGICAL UNIVERSITY BULLETIN»}

\section{Editorial Board}

Editor-in-chief

Pushkareva E.A.,Dr. of philosophical Sc.,Prof.of the NSPU Deputy editor-in-chief

Mayer B.O., Dr. of philosophical Sc., Prof. of the NSP Pedagogical Sciences and Psychology

Sinenko V.Ya, Dr. of Pedagogical Sciences, Professor Bogomaz S.A., Dr. of Psychological Sc., Prof. (Tomsk) Philosophy and Humanities Sciences

Mayer B.O., Dr. of philosophical Sciences, Professor Zverev V.A., Dr. of Historical Sciences, Professor Earth Sciences. Physics, Mathematics, Engineering Sciences

Trofimov V.M., Dr. of Physical and Mathematical Sciences, Professor

Social and Economics Sciences

Ryapisov N.A., Dr. of Economic Sciences, Professor Biological, Chemical Sciences and Medicine

Aizmam R.I., Dr. of Biological Sciences, Prof. of the NSPU, Corr-Member of IASHS

Prosenko A.E., Dr. of chemical Sciences, Professor Cultural and Art Sciences

Chaplya T. V., Dr. of Cultural Sciences, Professor Philology Sciences

Tripolskay T. A., Dr. of Philological Sciences, Prof.

\section{International Editorial Council}

Aizman O., Ph.D., M.D., Karolinska Institute, (Stockholm, Sweden);

Angelica Rieger, Dr., Professor (Aachen, Germany)

Anna Paola Bonola, Professor Università Cattolica del Sacro Cuore (Milan, Italy)

Balgimbekov Sh.A., Dr. of Medical Sciences, Professor (Almaty, Kazakhstan)

Buhtova B., Ph.D., Masaryk University (Brno, Czech Republic)

Chagin A., Ph.D., Karolinska Inst. (Stockholm, Sweden) Charles S. Wingo, M. D., Professor, University of Florida (Gainesville, Florida, USA)

Gianni Celsi, Ph.D., Professor, Uppsala University, (Uppsala, Sweden)

Liberska H. Dr. of Psychol. Sciences, Prof., Kazimierz Wielki University (Bydgoszcz, Poland)

Logunov D., Ph.D., University of Manchester (Manchester, United Kingdom)

Maurizia Calusio, Senior Researcher in Russian Literature, $\mathrm{PhD}$ (Milan, Italy)

Mukataeva Zh.M., Dr. of Biological Sciences (Pavlodar, Kazakhstan)

Walkenhorst Philipp, Dr., Professor, University of Cologne (Cologne, Germany)

Šmajs Jozef, Dr. of Philosophy, Professor, Masaryk University (Brno, Czech Republic)

Yu Wen Li, Ph.D., Professor Peking University (Peking, People's Republic of China)

\section{Editorial Council}

Chairman of Editorial Council

Gerasev A.D., Dr. of Biological Sc., Prof. (Novosibirsk)

Aftanas L.I., Dr. of Medical Sc., Prof., Acad. of RAMS (Novosibirsk)

Balikoev V.Z., Dr. of Economical Sc., Prof. (Novosibirsk) Bezrukih M.M., Dr. of Biological Sc., Prof. (Moscow) Berezhnova E.V., Dr. of Pedagogical Sc., Prof. (Moscow) Chupahin N.P.,Dr. of Philosophical Sc., Prof. (Tomsk) Dymarski M.J., Dr. of philological Sciences, Professor (St. Petersburg, Russia)

Fedorov V.I., Dr. of Biological Sc., Prof. (Novosibirsk) Galazhinsky E.V., Dr. of Psychological Sc., Professor, the academician of RAE (Tomsk)

Ivanova L.N., Dr. of Medical Sc, Prof., Academ. of RAS, Institute of Citology and Genetics (Novosibirsk)

Kazin E.M., Dr. of Biological Sc., the academician of IASHS, Professor (Kemerovo)

Klochko V.E., Dr. of Psychological Sc., Prof. (Tomsk) Knyazev N.A., Dr. of Philosophical Sc., Prof. (Kasnoyarsk) Kondakov I.V., Dr. of Philosophical Sc., Prof., Academ. of Russian Academy of Sciences (Moscow)

Krasnoryadstceva O.M., Dr. of Psychological Sciences, Professor (Tomsk)

Krivoshekov S.G., Dr. of Medical Sc., Prof. (Novosibirsk) Kudashov V.I., Dr. of Philosophical Sciences, Professor (Kasnoyarsk)

Kustova G.I., Dr. of philological Sciences, Professor (Moscow, Russia)

Medvedev M.A., Dr. of Medical Sc., Prof., the Academic. of RAMS, Institute of Medical Genetics (Tomsk, Russia)

Mokretsova L.A., Dr. of Pedagogical Sciences, Professor (Biysk, Russia)

Ovchinnikov Yu.E., Dr. of Physical and Mathematical Sciences, Professor (Novosibirsk, Russia)

Pecherskaya T.I., Dr. of philological Sciences, Professor (Novosibirsk, Russia)

Puzirev V.P., Dr. of Medical Sc., Prof., the Academician of RAMS, Institute of Medical Genetics (Tomsk, Russia) Seryi A.V., Dr. of Psychological Sc., Prof. (Kemerovo) Shoshenko K.A., Dr. of Medical Sc., Prof. (Novosibirsk) Vinokurov Yu.I., Dr. of Geography Sc., Prof. (Barnaul) Zhukotskaya Z.R., Dr. of Cultural Sciences, Professor (Nizhnevartovsk)

Zhafyarov A.Zh., Dr. of Physical and Mathematical Sc., Prof., Corr.- Member of the RAE (Novosibirsk)

The journal leaves 6 times a year The academic journal is established in 2011

Editorial publishing department: 630126, Novosibirsk, Vilyuiskaya, 28 tel. +7(383)244-34-50

E-mail: vestnik.nspu@gmail.ru 


5(21)2014 www.vestnik.nspu.ru ISSN 2226-3365

\section{СОДЕРЖАНИЕ}

\section{ПЕДАГОГИЧЕСКИЕ И ПСИХОЛОГИЧЕСКИЕ НАУКИ}

Айзман Р.И. (Новосибирск, Россия). Проблемы подготовки преподавателя ОБЖ и пути их

решения

Репин Ю. В. (Екатеринбург, Россия). Современное состояние проблемы формирования культуры безопасности жизнедеятельности в образовательных организациях общего и высшего образования

Хуснутдинова 3. А. (Уфа, Россия). К вопросу подготовки специалистов по организации антинаркотической профилактической работы в образовательной среде

Зуев А.М (Сергиев Посад, Россия). Наиболее актуальные проблемы преподавания предмета ОБЖ в свете требований ФГОС

\section{ФИЛОСОФСКИЕ И ГУМАНИТАРНЫЕ НАУКИ}

Павлова В.Д., Чупахин Н.П. (Томск, Россия). От философии смысла к философии культуры ......... Жукоикая 3.Р., Фаненштыль О.А. (Нижневартовск, Россия). Инженерно-техническая интеллигенция тюменской области в современном историографическом анализ ...

\section{НАУКИ О ЗЕМЛЕ. ФИЗИКО-МАТЕМАТИЧЕСКИЕ И ТЕХНИЧЕСКИЕ НАУКИ}

Бакаев В. А. (Новосибирск, Россия). Экологическое состояние лимносистем северо-запада Барабинской низменности

\section{СОЦИАЛЬНО-ЭКОНОМИЧЕСКИЕ НАУКИ}

Сулима С. В. (Актобе, Казахстан), Чернобай О.Л. (Новосибирск, Россия). Международные экономические отношения регионов и государств (на примере России и Казахстана)

Ионова Н. В. (Новосибирск, Россия). Малое предпринимательство в Сибирском Федеральном Округе: современное состояние и тенденции развития

Латуха О. А., Пушкарева Е. А. (Новосибирск, Россия). Экономика общества знания: научнообразовательные приоритеты развития (обзор проблемы)

\section{БИОЛОГИЧЕСКИЕ, ХИМИЧЕСКИЕ, МЕДИЦИНСКИЕ НАУКИ}

Халфина Р.Р., Кислицьлн М.Н., Минуллин А.З. (Уфа, Россия). Актуальность поиска новых методик отбора курсантов в служебно-прикладные виды спорта

Головин М. С. АйзманР.И. (Новосибирск, Россия). Повышение психо-функциональных резервов организма студентов под влиянием аудиовизуальной стимуляции

Хайбуллина 3.P. (Ташкент, Узбекистан). Проявления метаболического синдрома у больных мультифокальным атеросклерозом

Хайбуллина 3. Р., Баженов Л. Г., Косникова И. В. (Ташкент, Узбекистан). Характеристика метаболических нарушений у больных с различными типами поражения коронарных артерий при ишемической болезни сердца 


\section{КУЛЬТУРОЛОГИЯ И ИСКУССТВОВЕДЕНИЕ}

Цюй Чуньлэй (Шаньдун, Китай), Е. В. Тихомирова (Новосибирск, Россия). Языковые репрезентации универсалии срединный путь в русской и китайской культуре

\section{ФИЛОЛОГИЧЕСКИЕ НАУКИ}

Бычихина О.В. (Новосибирск). Анализ основных коммуникативных моделей российского и китайского бизнес-дискурсов ....

Пермякова Т.Н. (Новосибирск, Россия). Лексикографическое портретирование служебных слов (на примере частицы-союза только)

Бачурина Е.Б. (Новосибирск, Россия). Стилистическое варьирование дискурса Л.Н. Гумилева при использовании им компаративных тропов

Катенева И.Г. (Новосибирск, Россия). Способы самопрезентации в публицистических текстах Дмитрия Быкова (на материале «Новой газеты») 


\section{CONTENTS}

\section{PEDAGOGICAL SCIENCES AND PSYCHOLOGY}

Aizman R. I. (Novosibirsk, Russian Federation). Problems of preparation of teacher of «safety of life» and ways of their decision

Repin Y. V. (Yekaterinburg, Russian Federation). Current status of the problem of formation of culture of safety in educational institutions of secondary and higher education

Khusnutdinova Z. A. (Ufa, Russian Federation). Training of specialists on organization of antinarcotic prophylactics within the educational media

Zuev A. M. (Sergiev Posad, Russian Federation). The vital problems of the teaching of object basics of safety of life in light of the requirements state federal educational standard

Smoleusova T. V. (Novosibirsk, Russian Federation). Topical issues of implementation of the state federal educational standard

\section{PHILOSOPHY AND HUMANITIES SCIENCES}

Pavlova V. D., Chupahin N. P. (Tomsk, Russian Federation). Philosophy of meaning to philosophy of culture

Zhukotskaya Z. R., Fanenshtyl O. A. (Niznevartovsk, Russian Federation). Engineering and technical intelligentsia of the Tyumen region in modern historiographical analysis ...

\section{EARTH SCIENCES. PHYSICS, MATHEMATICS, ENGINEERING SCIENCES}

Bakaev V. A. (Novosibirsk, Russian Federation). Environmental status limnosistems NorthWest Baraba lowland

\section{SOCIAL AND ECONOMICS SCIENCES}

Sulima S. V. (Aktobe, Republic of Kazakhstan), Chernobay O. L. (Novosibirsk, Russian Federation). International ties of the subjects of the Siberian Federal District in the economic sphere (on the example of the Novosibirsk region and the Republic of Kazakhstan)

Ionova N. V. (Novosibirsk, Russian Federation). Small business in Siberian Federal District: current state and tendencies of the development

Latuha O. A., Pushkareva E. A. (Novosibirsk, Russian Federation). Business knowledge society: scientific and educational development priorities (overview of the problem) 


\section{CONTENTS}

\section{BIOLOGICAL, CHEMICAL SCIENCES AND MEDICINE}

Halfina R. R., Kislitsyn M. N., Minullin A. Z. (Ufa, Russian Federation). Relevance of search of new techniques of selection of cadets in office and applied sports

Golovin M. S., Aizman R. I. (Novosibirsk, Russian Federation). Increase of psycho-functional reserves of student's organism under influence of audiovisual stimulation

Khaybullina Z. R., Kosnikova I. V. (Tashkent, Uzbekistan). Components of the metabolic syndrome at patients with the multifocal atherosclerosis

Khaybullina Z. R., Bajenov L. G., Kosnikova I. V. (Tashkent, Uzbekistan). Characteristic of metabolic disorders at patients with ischemic heart disease with various types of coronary arteries damage

\section{CULTURALSCIENCEANDARTCRITICISM}

Qu Chunlei (Shandong, People's Republic of China), Tikhomirova E. E. (Novosibirsk, Russian Federation). Language representation of the universal middle path in the Russian and Chinese culture

\section{PHILOLOGICAL SCIENCES}

Bychikhina O. V. (Novosibirsk, Russian Federation). Analysis of the main communicative models of Russian and Chinese business discourses

Permyakova T. N. (Novosibirsk, Russian Federation). Lexicographical portraying functional words (by the example of the particle-conjunction tol'ko)

Bachurina E. B. (Novosibirsk, Russian Federation). Stylistic variation of I. N. Gumilyov's discourse by comparative tropes

Kateneva I. G. (Novosibirsk, Russian Federation). Methods of self-presentation in mass media texts by Dmitry Bykov (on materials of the «New newspaper») 


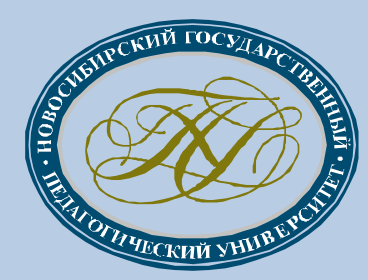

\title{
www.vestnik.nspu.ru
}

\section{ПЕДАГОГИЧЕСКИЕ И ПСИХОЛОГИЧЕСКИЕ}

\author{
НАУКИ
}




\title{
УДК 378.1
}

\section{ПРОБЛЕМЫ ПОДГОТОВКИ ПРЕПОДАВАТЕЛЯ ОБЖ И ПУТИ ИХ РЕШЕНИЯ}

\author{
Р. И. Айзман (Новосибирск, Россия)
}

В статье представлен доклад, сделанный на совещуании руководителей кафедр и факультетов профиля «Безопасность жизнедеятельности» в рамках заседания УМК по безопасности жизнедеятельности УМО по образованию в области подготовки педагогических кадров 2-3 октября 2014 г. в г. Новосибирске. Статья состоит из трех разделов. В первом разделе освещзется актуальность изучения данной дисциилины в образовательных учреждениях в связи с внутренними и внешними угрозами национальной безопасности странь (социальноэкономическими, политическими, военньми, технологическими и т. д.), а также проблемами в системе образования (ухудшение здоровья учащихся, низкий уровень охраны труда, высокие риски суицидности и психологических проблем). В то же время имеется ряд нормативноправовых документов разного уровня, определяюших формирование здорового и безопасного образа жизни всех участников образовательного процесса. Во второй части статьи анализируются недостатки в изучении дисииплины и предлагаются варианты их решения. Особое внимание уделяется вопросам преемственности изучения разделов, содержанию курса, формированию межпредметных связей, кадровому потенциилу преподавателей организащий общего и среднего образования, материально-технической базе, учебно-методическому обеспечению дисииплиныл. В третьем разделе излагается опьт кафедры анатомии, физиологии и безопасности жизнедеятельности по развитию преподавания безопасности жизнедеятельности в НГПУ и НИИ здоровья и безопасности, в организации системы подготовки и переподготовки педагогических кадров по профилю «Безопасность жизнедеятельности» и решении подняmых вопросов.

Ключевые слова: безопасность жизнедеятельности, здоровый и безопасный образ жизни, подготовка и переподготовка кадров, нормативно-правовые документы.

Необходимость расширения и уточнения позиции безопасности жизнедеятельности, как учебной дисциплины на уровне среднего и высшего образования диктуется ее актуальностью в современном обществе
[7; 13]. Это, во-первых, высокая смертность и травматизм в обыденных ситуациях, а не в чрезвычайных ситуациях и катастрофах. Так, ежегодные людские потери в России составляют:

\footnotetext{
Айзман Роман Иделевич - доктор биологических наук, профессор, заслуженный деятель науки РФ, заведующий кафедрой анатомии, физиологии и безопасности жизнедеятельности, директор НИИ здоровья и безопасности, Новосибирский государственный педагогический университет.

E-mail: aizman.roman@yandex.ru
} 
1. На дорогах: 32 тыс. человек; 200 тыс. человек получают телесные повреждения (10-15 \% умирает).

2. На пожарах: 19 тыс. человек; 20 тыс. человек получают телесные повреждения.

3. От криминальных действий: 34 тыс. человек; 50 тыс. человек - пропавших без вести (50 \% из них - убитые).

4. От неумеренного употребления алкоголя и наркотиков:

5. 50 тыс. человек от передозировки наркотиков; 40 тыс. чел от отравления алкоголем.

6. От утопления: 20 тыс. человек.

7. От суицидов: 50 тыс. человек. Подростковый суицид захлестнул некоторые регионы страны. Если для каждой страны условный норматив суицидов не должен превышать 20 на 100 тыс. населения, то средняя цифра по России сейчас превышает 36/100 тыс., а по некоторым регионам, например, как Тува 66-69/100 тыс.

8. От бытового и производственного травматизма: 100 тыс. человек.

К сожалению, эти данные, представленные около 10 лет назад, мало изменились за последние годы. Более того, распространяющаяся наркомания и токсикомания привела к тому, что сейчас на учете состоит около 2,5 млн людей, преимущественно молодого возраста, регулярно потребляющих наркотические и другие психотропные вещества, что, по мнению специалистов, примерно в 4-5 раз меньше реальных величин.

Кроме этого, существуют и другие очень актуальные на сегодняшний день проблемы для страны и системы образования. Это депопуляция страны, особенно в условиях Сибири. По данным академика В. П. Казначеева, для того чтобы Сибирь была экономически и социально значимым регионом, надо чтобы здесь проживало не менее 50 млн человек. Сейчас за Уральскими горами проживает менее 25 млн человек, причем, тенденция такой внутренней миграции в Европейскую часть продолжается. С момента введения ЕГЭ и возможности поступления по его результатам в вузы, отмечается отток наиболее отличившихся выпускников школ Сибири и Дальнего Востока в европейские вузы страны. Эта депопуляция, конечно, значительно снижает возможности экономического, социального, культурного и научного развития страны, особенно регионов Сибири.

В числе актуальных проблем, влияющих на безопасность России и общества, следует выделить многочисленные внутренние и внешние угрозы национальной безопасности: коррупция, социальное расслоение, низкий технологический уровень промышленности, недостаточное для обеспечения продовольственной безопасности состояние сельского хозяйства, перманентные реформы в образовании, реформирование научной сферы, военные действия на Украине, межрелигиозные и межнациональные конфликты, терроризм, и т. д.), которые, к сожалению, возрастают, а не уменьшаются.

Таким образом, проблема формирования безопасного поведения становится проблемой национального масштаба, что нашло отражение в Стратегии национальной безопасности РФ до 2020 года, требует системного изложения в современных учебниках и изучения в образовательных учреждениях.

Актуальность имеет также проблема здорового и безопасного образа жизни обучающихся и студентов [2-3]. Так, по данным Министерства здравоохранения (2012 г.), состояние здоровья учащихся школ за последние пять лет ухудшилось на 16-32 \% в зависимости от возрастной группы, категории и т. д. Среди выпускников школ только 10-15 \% можно считать практически здоро- 
выми, а среди призывников, по данным медицинских комиссий военкоматов, 40-45 \%. В некоторых районах до 50 \% призывников не могут быть призваны на военную службу по состоянию психического и физического здоровья. Немаловажную роль в создании такой ситуации играют те образовательные системы и технологии, которые вызывают школьную зависимую патологию, а также неразвитость системы организации медикопсихологической и социальной помощи участникам образовательного процесса [6]. Как это не парадоксально, но с переходом на подушевое финансирование в системе образования, многие образовательные организации начали отказываться от услуг школьных психологов, социальных педагогов, полагая, что предметы естественнонаучного, физикоматематического, гуманитарного циклов значительно важнее, чем проблемы, связанные с психическим и социальным здоровьем учащихся. Следует также указать на неэффективную службу охраны труда в системе образования: большинство преподавателей образовательных учреждений не владеет знаниями основ охраны труда. Это, наверное, уже вопрос законодательства, который должен обязать всех преподавателей в системе образования овладеть знаниями охраны труда, для того чтобы уметь правильно организовать образовательный процесс и систему защиты.

Bce указанные проблемы вызывают беспокойство общественности и руководства страны. Можно привести целый ряд нормативно-правовых документов, определяющих направления формирования здорового и безопасного образа жизни в образовании.

Государственная политика в сфере сохранения здоровья и безопасности обучающихся опирается на следующие документы:
- Указ Президента РФ № 537 «О Стратегии национальной безопасности РФ до 2020 г.», утвержден 12 мая 2009 г.

- Концепция долгосрочного социальноэкономического развития страны до 2020 г., раздел 3.4. «Образование»:

- формирование здорового образа жизни;

- формирование новых экологических стандартов жизни.

- Основные направления модернизации образования на 2011-2015 гг.:

- формирование норм поведения здорового и безопасного образа жизни детей, подростков и молодежи;

- разработка соответствующих учебных программ для подготовки, переподготовки и повышения квалификации специалистов общеобразовательных учреждений.

- Санитарно-гигиенические требования и требования к безопасности (Санитарноэпидемиологические требования к условиям и организации обучения в общеобразовательных учреждениях - СанПиН 2.4.2.2821-10).

- Приказ Министерства образования и науки РФ от 28 декабря 2010 г. № 2106 «Об утверждении федеральных требований к образовательным учреждениям в части охраны здоровья обучающихся, воспитанников».

- Приказ Министерства образования и науки РФ от 16 июня 2014 г. № 658 «Порядок проведения социальнопсихологического тестирования лиц, обучающихся в общеобразовательных организациях и профессиональных образовательных...»

Конечно, это далеко не все документы, касающиеся данной проблемы, но в них об- 
ращается особое внимание на эти вопросы, и они должны быть основополагающими в работе образовательного учреждения любого уровня. Однако за этими приказами отсутствует технология их реализации, поэтому каждый регион поступает по своему разумению.

В настоящей статье хотим остановиться на тех проблемах, которые, на наш взгляд, возникают в преподавании дисциплины безопасности жизнедеятельности в образовательных организациях разного уровня, а также некоторых предлагаемых вариантах их решения.

Во-первых, если говорить о самом содержании курса в системе подготовки учащейся молодежи, то независимо от того, как его правильно называть - «Основы безопасности жизнедеятельности» (ОБЖ) или «Безопасность жизнедеятельности» (БЖ), - принципиально важно, что это касается всех уровней образования. На мой взгляд, проблема, заключается во фрагментарности изложения многих разделов курса или отсутствие важных для современной жизни разделов. Так, отсутствуют, особенно в школьном курсе, вопросы семейной и психологической безопасности, слабо отражены проблемы информационной, социальной безопасности и т. д. Очень часто разделы не связаны ни логической цепью, иногда даже не отвечают возрастным особенностям учащихся. Всё это требует пересмотра образовательных программ для учебных заведений всех уровней, в которых должны быть отражены на современном уровне указанные вопросы. Причем, они должны иметь выраженный региональный характер, отражая те проблемы, которые наиболее актуальны для данного региона.

Во-вторых, недостаточное количество часов на изучение курса. За 36 часов аудиторных занятий в вузе невозможно дать тот минимум знаний, умений и навыков, которые необходимы для правильного поведения в той или иной ситуации. И конечно, то количество часов, которое заложено в школьных программах, тоже абсолютно недостаточно. В результате отмечается низкий уровень у обучающихся практических навыков и умений, которые связаны также с недостаточной материально-технической базой образовательных организаций и, к сожалению, с недостаточной подготовкой школьных учителей. Отсутствуют четкие комплексные качественные и количественные критерии, которые позволяют оценивать уровень освоения курса, как на школьном, так и среднем и вузовском уровнях. Поэтому необходимо определить минимум часов на изучение курса ОБЖ/БЖ: для вуза это должно быть не менее трех зачетных единиц, т. е. 108 академических часов для всех профилей педагогического образования, а для системы общего образования до 225 часов. Нужно разработать программы, которые обеспечили бы преемственность изучения курса с дошкольного и до общего среднего образования, разработать критерии оценки уровня компетентности студента и учителя в области здорового и безопасного образа жизни. Для характеристики здоровьесберегающей деятельности образовательного учреждения и комплексной оценки состояния здоровья учащихся в соответствии с Приказом № 2106 от 28 декабря 2010 г. и новыми ФГОС, в курс безопасности жизнедеятельности следует ввести раздел «Мониторинг физического и психического здоровья человека и здоровьесберегающей деятельности образовательной организации». Считаем необходимым значительно расширить раздел, касающийся освоения практических навыков в области оказания первой и неотложной помощи в различных ситуациях. Разработка модульной унифицированной для педагогиче- 
ских вузов основной образовательной программы по БЖ позволит решить многие вопросы академической мобильности студентов.

Следующая проблема, на которой следует остановиться, это педагогические кадры. Сегодня курс БЖ преподают до 85 \% учителей без специального образования: биологи, историки, географы и т. д. и военные отставники. Это понятно, потому что количество учебных часов по ОБЖ в школе недостаточно, чтобы обеспечить нагрузку учителя на полную ставку, часто ставка преподавателяорганизатора ОБЖ или заместителя директора по безопасности, которая рекомендуется Министерством образования и науки, директора отвергают, и поэтому ОБЖ становится дополнением к другому предмету. В этих условиях, естественно, качественно на высоком уровне преподавать дисциплину невозможно. Поэтому мы выносим следующее предложение: условием преподавания курса ОБЖ в школе должно стать профильное образование преподавателя по БЖ. Понятно, что невозможно подготовить такое количество учителей сразу, поэтому необходимо расширять и внедрять систему повышения квалификации и переподготовки кадров по профилю «Безопасность жизнедеятельности» в рамках педагогического образования. При вузах должны быть созданы центры такой подготовки, в качестве которых могут быть профильные кафедры и региональные центры по развитию преподавания БЖ. Для повышения статуса и престижа учителя ОБЖ мы уже два года проводим региональный конкурс на звание «Лучший учитель ОБЖ» с оценкой теоретических знаний и практических навыков, что позволяет стимулировать интерес учителей к своей профессиональной деятельности. Мы считаем, что такой конкурс должен стать общероссийским.
Важная проблема в преподавании ОБЖ/БЖ - это отсутствие межпредметных связей. Отсутствие таких взаимосвязей на уровне программ и содержания создает целый ряд затруднений в формировании широкого мировоззрения по безопасности. Поэтому одним из вариантов решения может быть подготовка педагогов-бакалавров по двум профилям, что позволит, с одной стороны, выпускника педвуза обеспечить достаточной подготовкой для преподавания в школе нескольких предметов и работой на полную ставку, а с другой стороны, создать предпосылки для развития межпредметных связей. Ряд вузов ведет сейчас такую подготовку бакалавров, объединяя профили безопасности жизнедеятельности и физической культуры, БЖ и географии, БЖ и биологии и т. д. Поиск сочетаний профилей подготовки должен быть функцией самих вузов и зависеть от материально-технической, у учебно-методической, кадровой базы, потребностей региона и т. д. Большую роль в повышении квалификации учителей ОБЖ могут сыграть магистратуры по БЖ в вузах, имеющих соответствующие возможности. Некоторые учителя школ идут обучаться в такую магистратуру, имея возможность получить степень магистра по соответствующему профилю.

Одним из вопросов в подготовке педагогических кадров по БЖ является обеспечение слушателей учебно-методической литературой. До 2011 г. все предметы специальности БЖ изучались по одному или двум учебникам, в которых излагались основные вопросы общей и техносферной безопасности [14], а также по внутренним учебнометодическим материалам. С 2011 по 2013 гг. коллективом авторов Новосибирского, Московского, Оренбургского, Уральского вузов под руководством Р. И. Айзмана (НГПУ) и С. В. Петрова (МПГУ) было создано и издано 
29 учебников по различным аспектам безопасности жизнедеятельности, в которых, по сути, раскрыты основные вопросы всех дисциплин основной образовательной программы подготовки бакалавра по БЖ [1, 5, 8-13]. Конечно, они не лишены недостатков: нет учебников по семейной безопасности, требуют расширения учебники по информационной и социальной безопасности, в связи с расширением социальных угроз и т. д., но они стали базой для углубленного изучения различных аспектов здоровья и безопасности.

В этом году по нашей инициативе на базе Новосибирского государственного педагогического университета организован первый международный отраслевой конкурс «Университетская книга-2015» по направлению «Здоровье и безопасность». Конкурсу идет с 1 сентября 2014 г. по 5 февраля 2015 г. Вся информация об этом конкурсе опубликована в журналах «Университетская книга» и «Вестник НГПУ», а также на сайте www.niizib.ru Это позволит создать информационно-методическую базу по БЖ, провести инвентаризацию того учебного и научного материала, который накопился в России и странах СНГ.

Завершая обсуждение проблем преподавания БЖ, следует упомянуть также важность материально-технической базы, которая во многих вузах и школах не отвечает современным требованиям. Следует разработать стандарт оснащения курса БЖ, который необходим для образовательных организаций разного уровня. Нужны современные отечественные тренажёры, приборы и оборудование для отработки различных практических навыков, которые сейчас, к сожалению, очень дорого стоят, и поэтому многие учебные заведения не могут себе позволить использовать эти комплексы.
Решение поставленных в настоящей статье вопросов позволит дать новый импульс развитию курса БЖ, изучение которого с каждым годом становится все более актуальным для учащейся молодежи [3-4, 7, 13].

Многие из аспектов преподавания БЖ, поднятые в данной статье, реализованы в НГПУ благодаря вниманию ректората к этому направлению [4]. В чем же специфика подготовки студентов по БЖ в нашем вузе? Так, за 14 лет после открытия специальности БЖ, а затем профиля бакалавриата и магистратуры, мы уделяли большое внимание глубокой медико-биологической подготовке студентов, что, с одной стороны, связано с традициями кафедры, ее кадровым потенциалом, с другой, - с нашим убеждением в том, что хорошая медико-биологическая подготовка является основой знаний о человеке, его возможностях, резервах, а, следовательно, о здоровье и безопасности. Даже при резком сокращении учебных практик мы сохранили учебную практику совместно с МЧС в лагере «Юный спасатель», где в реальной ситуации студенты осваивают различные навыки выживания в автономных условиях, а также в условиях, которые приближены к естественным. Кроме того, это участие студентов в олимпиадах. Студенты нашего вуза приняли участие во всех региональных, республиканских олимпиадах. И за последние три года они всегда привозили первые места в общекомандном зачёте. Это возможность получения специализации, дополнительного образования, продолжения обучения по профилю послевузовского образования, которую мы можем предоставить студенту по его желанию. Очень важным является сотрудничество кафедры с другими вузами и центрами МПГУ, Уральским ГПУ, СанктПетербургским ГПУ им. А. И. Герцена и др., которое позволяет расширять возможности 
привлечения преподавателей и студентов для обучения. Хорошие творческие связи, которые имеются с ГУ МЧС по г. Новосибирску и Военным институтом МВД им. Яковлева, на базе которых мы часто проводим студенческие олимпиады, позволили создать и оборудовать экспериментальную площадку по БЖ. НГПУ имеет факультет повышения квалификации, региональный центр СФО по развитию преподавания БЖ, а также созданный четыре года назад, научно-исследовательский институт здоровья и безопасности (НИИЗиБ), который играет важную роль в разработке и интеграции программ работы с системой образования в целом. Благодаря этим структурам в настоящее время мы осуществляем повышение квалификации и профессиональную переподготовку по трём направлениям: мониторинг здоровья субъектов образовательного процесса, безопасность жизнедеятельности и адаптивная физическая культура. Те материально-технические условия, которые созданы, позволяют вести обучение в дистантной форме, а не только в очной, заочной или комби- нированной, что расширяет географию наших слушателей и позволяет охватить многие регионы Сибири этой системой подготовки.

Сотрудники кафедры стали основными авторами при подготовке учебных пособий по БЖ, большинство из которых завоевали девять золотых медалей разных конкурсов, а вся серия книг удостоена Золотой медали конкурса «Университетская книга - 2012», три учебника по медико-биологическим направлениям безопасности были удостоены звания «Лучший учебник 21 века» и награждены на Международной московской ярмарке (2009) золотыми медалями. На кафедре разработаны электронные паспорта здоровья и физической подготовленности субъектов образовательного процесса, для оценки риска развития психических зависимостей, которые уже широко используются в разных регионах страны для мониторинга здоровья учащихся, студентов, призывников, преподавателей, выявления аддикций, выбора профессионального маршрута и т. д. (рис. 1,2$)$.

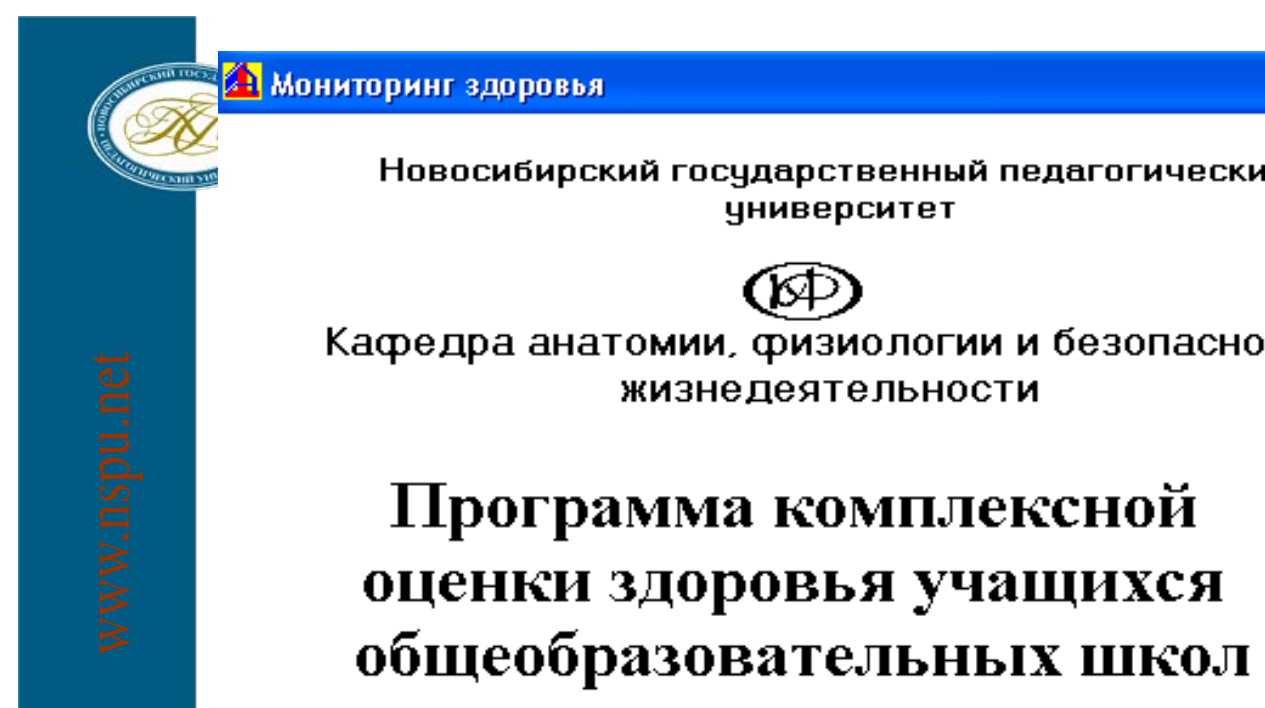

г. Новосибирск 


5(21)2014 www.vestnik.nspu.ru ISSN 2226-3365

Рисунок 2.

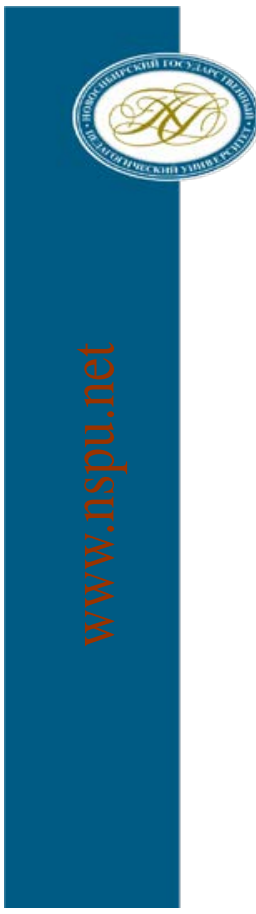

Вид тестовой программы



Такая широкая подготовка будущих педагогов, на наш взгляд, связана с тем, что функции педагога ОБЖ в школе значительно расширяются по сравнению с общепринятым мнением. Мы считаем, что среди функций надо выделить системно-деятельностный nодxод, когда учитель должен овладеть новыми функциями в области формирования культуры здоровья и безопасного образа жизни у обучающихся. Это компетентност- ный подход, под которым мы понимаем, что сам учитель должен владеть всеми теми качествами, знаниями и навыками, которые он хочет формировать у обучающихся. Это медико-психологический подход, заключающийся в разработке и внедрении в практику критериев оценки методов здорового и безопасного образа жизни учащегося. Эта цель и определила задачи ректората и кафедры в подготовке будущих педагогов по ОБЖ.

\section{СПИСОК ЛИТЕРАТУРЫ}

1. Айзман Н. И., Айзман Р. И., Зиньковская С. М. Психологические основы безопасности человека: учебное пособие. - Новосибирск: АРТА, 2011. - 272 с.

2. Айзман Р. И. Современные представления о здоровье и критерии его оценки // Сибирский педагогический журнал. - 2012. - № 9. - С. 85-90.

3. Айзман Р. И. Здоровье педагогов и обучающихся - ключевая задача современной школы // Вестник Новосибирского государственного педагогического университета. - 2012. - № 3 (7). C. 24-35.

4. Айзман Р. И. Подготовка бакалавров и магистров педагогического направления по профилю «Безопасность жизнедеятельности» в НГПУ // Проблемы и пути совершенствования гражданской обороны в субъектах Российской Федерации Сибирского федерального округа: Материалы научно-практ. конф. 26.09.2012. - Новосибирск. - С. 34-38. 
5. Айзман Р. И., Бубнов В. Г., Рубанович В. Б., Суботялов М. А. Основы медицинских знаний: учебное пособие. - Новосибирск: АРТА, 2011. - 224 с.

6. Айзман Р. И., Казин Э. М., Федоров А. И., Шинкаренко А. С. Проблемы и задачи здоровьесберегающей деятельности в системе образования на современном этапе // Вестник Новосибирского государственного педагогического университета. - 2014. - № 1 (17). - С. 9-17.

7. Айзман Р. И., Королёв В. А. Значение курса «Основы безопасности жизнедеятельности» в современной подготовке школьников // Сибирский педагогический журнал. - 2012. - № 7. - С. 210-215.

8. Айзман Р. И., Петров С. В., Ширшова В. М. Теоретические основы безопасности жизнедеятельности: учебное пособие. - Новосибирск: АРТА, 2011. - 208 с.

9. Айзман Р. И., Шуленина Н. С., Ширшова В. М. Основы безопасности жизнедеятельности: учебное пособие. - Новосибирск: АРТА, 2011. - 367 с.

10. Гиренко Л. А., Петров С. В., Слинькова И. П. Опасности социального характера и защита от них: учеб.-метод. комплекс. - Новосибирск: НГПУ, 2010. - 264 с.

11. Михайлов А. А., Петров С. В., Кисляков П. А. Опасности социального характера и защита от них: учеб. пособие. - М.: Русский журнал, 2009. - 252 с.

12. Петров С. В., Айзман Р. И., Лысова Н. Ф. Безопасность образовательного учреждения: учебное пособие. - Новосибирск: АРТА, 2012. - 272 с.

13. Репин Ю. В., Ширшов В. Д., Гафнер В. В. Образовательная концепция предмета «Основы безопасности жизнедеятельности. - Екатеринбург: УрГПУ, 2014. - 25 с.

14. Русак О. Н., Малаян К. Р., Занько Н. Г. Безопасность жизнедеятельности: учеб. пособие; 3-е изд., испр., доп. - СПб: Лань, 2000. - 448 с. 
Aizman Roman Idelevich, Doctor of Biological Sciences, Professor, Head of Department of Anatomy, Physiology and Safety of Life, Director of Scientific Research Institute of Health and Safety of Life, Novosibirsk State Pedagogical University, Novosibirsk, Russian Federation.

E-mail: roman.aizman@mail.ru

\title{
PROBLEMS OF PREPARATION OF TEACHER OF "SAFETY OF LIFE" AND WAYS OF THEIR DECISION
}

\begin{abstract}
In article the report made at meeting of heads of departments and faculties of a profile "Safety of life" within the limits of session of teacher-methodic commission on safety of life by training in the field of preparation of pedagogical shots on October, 2-3 ${ }^{\text {nd }}, 2014$ in Novosibirsk is presented.

The article consists of three sections. In the first section the urgency of studying of the given discipline in educational institutions in connection with internal and external threats of national safety of the country (social and economic, political, military, technological, etc.), and also problems in an education system (deterioration of health of pupils, low level of a lab our safety, high risks of suicides and psychological pressure etc.) At the same time there is a number of standard-legal documents of the different level defining formation of a healthy and safe way of life of all participants of educational process. In the second part of the report lacks of studying of discipline are analyzed and variants of their decision are offered. The special attention is given to questions of continuity of studying of sections, the course maintenance, formation of intersubjective communications, personnel potential of teachers of the organizations of the general and secondary education, to material base, educationalmethodical maintenance of discipline. In the third section experience of Department of anatomy, physiology and safety of life on development of teaching of safety of life of NSPU, and scientific research institute of health and safety in the organization of system of preparation and retraining of pedagogical shots on a profile "Safety of life" and the decision of the lifted questions is stated.
\end{abstract}

\section{Keywords}

safety of life, a healthy and safe way of life, preparation and retraining of personnel, standardlegal documents

\section{REFERENCES}

1. Aizman N. I., Aizman R. I., Zin'kovskaya S. M. Psychological foundations of human security. Novosibirsk, ARTA Publ., 2011, 272 p. (In Russian)

2. Aizman R. I. Modern ideas about health and criteria for its evaluation. Siberian Education Journal. 2012, no. 9, pp. 85-90. (In Russian)

3. Aizman R. I. Health educators and students - key task of the modern school. Novosibirsk State Pedagogical University Bulletin. 2012, no. 3, pp. 24-35. (In Russian)

4. Aizman R. I. Bachelor's and master teacher direction in the profile "Safety" in Novosibirsk State Pedagogical University. Problems and ways to improve the civil defense in the Russian Federation in the Siberian Federal District. Materials science and practical conference. Novosibirsk, Novosibirsk State Pedagogical University Publ., pp. 34-38. (In Russian) 
5. Aizman R. I., Bubnov V. G., Rubanovich V. B., Subotyalov M. A. Fundamentals of medical knowledge. Novosibirsk, ARTA Publ., 2011, 224 p. (In Russian)

6. Aizman R. I., Kazin E. M., Fedorov A. I., Shinkarenko A. S. Problems and challenges of healthrelated activities within the education at the present stage. Novosibirsk State Pedagogical University Bulletin. 2014, no. 1, pp. 9-17. (In Russian)

7. Aizman R. I., Korolev V. A. Meaning of course "Basic Life" in the modern preparation of students. Siberian Education Journal. 2012, no. 7, pp. 210-215. (In Russian)

8. Aizman R. I., Petrov S. V, Shirshov V. M Theoretical foundations of life safety: a tutorial. Novosibirsk, ARTA Publ., 2011, 208 p. (In Russian)

9. Aizman R. I., Shulenina N. S, Shirshov V. M. Basic of life safety. Novosibirsk, ARTA Publ., 2011, 367 p. (In Russian)

10. Guirenko L. A., Petrov S. V., Slinkova I. P. Danger of social and protection against them. Novosibirsk, Novosibirsk State Pedagogical University Publ., 2010, 264 p. (In Russian)

11. Mikhailov A. A., Petrov S. V., Kisliakof P. A. Danger of social and protection against them. Moscow, Russian magazine Publ., 2009, 252 p. (In Russian)

12. Petrov S. V., Aizman R. I., Lysova N. F. Safety educational institution. Novosibirsk, ARTA Publ., 2012, 272 p. (In Russian)

13. Repin Yu. V., Shirshov V. D., Gafner V. V. Educational concept of the subject Fundamentals of safety. Yekaterinburg, Ural State Pedagogical University Publ., 2014, 25 p. (In Russian)

14. Rusak O. N, Malayan K. R., Zanko N. G. Life Safety. St. Petersburg, Lan Publ., 2000, 448 p. (In Russian) 
УДК 378.1

\title{
СОВРЕМЕННОЕ СОСТОЯНИЕ ПРОБЛЕМЫ ФОРМИРОВАНИЯ КУЛЬТУРЫ БЕЗОПАСНОСТИ ЖИЗНЕДЕЯТЕЛЬНОСТИ В ОБРАЗОВАТЕЛЬНЫХ ОРГАНИЗАЦИЯХ ОБЩЕГО И ВЫСШЕГО ОБРАЗОВАНИЯ
}

\author{
Ю. В. Репин (Екатеринбург, Россия)
}

\begin{abstract}
В статье анализируются основные проблемы развития предмета обучения «Основы безопасности жизнедеятельности» в системе общего образования, которые необходимо решить руководству образовательных организаций, органам управления образования по внедрению в образовательный проиесс федеральных государственных образовательных стандартов начального, основного и среднего общего образования. Отмечается, что в современных условиях необходимо обратить серьезное внимание на формирование культуры безопасности жизнедеятельности подрастающего поколения. В статье выделяются основные направления подготовки учителя безопасности жизнедеятельности - учителя ХХІ века, способного научить и убедить молодое поколение в необходимости соблюдения правил современной жизни, ведении здорового и безопасного образа жизни, обращая особое внимание на личную и общественную безопасность. В качестве выводов отмечаются вопросы необходимости разработки и внедрения в образовательный прочесс унифищированной основной образовательной программы подготовки студентов педагогических вузов по профилю «Безопасность жизнедеятельности», приемлемой во всех регионах России, а также внесение предложений для разработки проекта профессионального стандарта учителя безопасности жизнедеятельности.
\end{abstract}

Ключевые слова: предмет "Основы безопасности жизнедеятельности», учитель безопасности жизнедеятельности, здоровый и безопасный образ жизни, образовательный кластер безопасности жизнедеятельности.

Последние изменения в системе образования производят впечатление, что образование нашему государству нужно только на бумаге: ФГОСы, ГОСы, Закон об образовании.
Требования документов только для разработчиков. Где начинается практика - там возникают проблемы.

Репин Юрий Викторович - кандидат педагогических наук, профессор, декан факультета безопасности жизнедеятельности, Уральский государственный педагогический университет, почетный работник высшего профессионального образования РФ, действительный член Академии наук экологии, безопасности человека и природы.

E-mail: repin19502706@mail.ru 
Закон «Об образовании в Российской Федерации» представлен в таком объеме, что его сложно изучить, а тем более соблюдать. Например, на наш взгляд, в законе не целесообразно иметь статью о задолженностях студентов и переводе их с курса на курс. Все это можно отразить в различных разработанных положениях. В тексте закона много разъяснительного материала. Мы считаем, что закон должен содержать основные положения, закрепляющие процесс, и долго использоваться. Остальное всё можно отразить в нормативных актах.

Возьмем ФГОС общего образования. Разработанная ранее Образовательная концепция образовательной области «Безопасность жизнедеятельности» предполагает обучение учащихся вопросам безопасности с 1 по 11 классы. В начальной школе в виде «Окружающего мира», в основной и старшей школе - курс ОБЖ. Ввиду нехватки учителей безопасности жизнедеятельности было принято решение передать учителям начальных классов проведение занятий по этой тематике. Но учителя начальных классов сделали этот предмет своим, не всегда выполняя требования стандартов. Это можно исправить.

А вот когда мы начнем рассматривать требования ФГОС, то увидим, что образовательная область «Безопасность жизнедеятельности» в них почти отсутствует. «Окружающий мир» отнесли к естествознанию, в основной школе ОБЖ - к образовательной области «Физическая культура и ОБЖ» и только в среднем образовании есть «Основы безопасности жизнедеятельности». А где же основной предмет обучения ОБЖ? Ранее, когда ОБЖ был в национально-региональном компоненте, у него было свое определенное место. Там было все понятно.

До сих пор нет ни одного документа, который бы определил место образователь- ной области «Безопасность жизнедеятельности» в системе образования, даже высшего. Куда во ФГОС ВПО отнесли бакалавра профиля «Безопасность жизнедеятельности»? К естественнонаучному направлению педагогического образования, вместе с географией, биологией, экологией. С одной стороны, это можно понять, ведь безопасность жизнедеятельности зиждется на этих знаниях. Где же свое собственное начало? Оно растворилось во всех дисциплинах. Хотим напомнить, что основная цель предмета ОБЖ - это формирование у учащихся культуры безопасности жизнедеятельности. Думаем, не нужно напоминать сложность этого процесса. От случая к случаю, на редких мероприятиях, во второстепенных условиях это не сделаешь. Это сложный педагогический процесс, и отношение к нему должно быть серьезное, а не примерное, что нам предлагают в некоторых программах. Формирование знаний, умений и навыков нам понятно, а вот как формировать убеждение в соблюдении норм и правил безопасности жизнедеятельности - этому почему-то многие не учат. Для этого в учебном плане есть дисциплина «Методика обучения и воспитания безопасности жизнедеятельности» с большим объемом лекционных, практических и лабораторных занятий.

Разрозненность учебных программ, как в образовательных организациях общего, так и высшего педагогического образования приводит к различному толкованию самого образовательного процесса. Недопонимание значимости предмета ОБЖ руководителями образовательных организаций приводит к хаосу в процессе обучения. Хотя все хотят видеть положительный результат. Он будет тогда, когда будет квалифицированный учитель и четко организованный образовательный процесс. Где его взять? Ведь кадровая политика в 
образовательных организациях относительно учителей ОБЖ на низком уровне.

В современных условиях только та нация, которая сумеет создать более совершенную систему «Учитель», сделается лидером XXI века (Н. Н. Моисеев). По сути, речь идет о качественно новой работе учителя в изменяющихся социально-педагогических условиях.

Каким должен быть преподавательорганизатор ОБЖ? Наверное, в идеале, это, прежде всего, человек, повидавший трудности, испытавший на себе влияние опасных ситуаций, имеющий основание учить по принципу: делай, как я. Он должен сам любить детей и убеждать в необходимости быть осторожными и предусмотрительными. Нужны большой объем знаний, умение творчески донести их до обучаемых, увлечь ребят, азартность энергичность.

Процесс обучения курсу ОБЖ, независимо от его структуры, содержания и направленности, является творческим процессом формирования собственного отношения учащихся к предмету, событиям и явлениям действительности. Каждое занятие и встреча с обучаемыми не должны быть похожи друг на друга. Всякий раз они строятся с учетом многих, как постоянных, так и приходящих обстоятельств и являются творчеством преподавателя. Творчество невозможно без глубокого знания педагогики, психологии, передового опыта обучения и воспитания. Преподаватель-организатор ОБЖ - это личность уникальная, имеющая опыт и знания во всех образовательных дисциплинах, способная творчески анализировать любую ситуацию, найти и подсказать обучаемым их действия в процессе жизнедеятельности.

Нам вспоминается диалог с одним из докторов наук из Германии, который присутствовал на одном из семинаров в Московском педагогическом государственном университете (еще жив был Валерий Васильевич Марков). Он говорил о процессе обучения безопасности в быту у себя в стране. В Германии должность этого учителя высокооплачиваемая, допускаются к ней только специалисты, проходящие специальный конкурс каждые два года.

У нас же пока не пройдет этот стереотип военного руководителя, многими отвергаемый, успеха не будет. Кто идет учиться на профиль «Безопасность жизнедеятельности»? Выпускники в основном сельских школ, в большей степени женского пола. В селе больше понимают необходимость нашего сложного процесса. Понимание идет с окраин.

Что касается учебников и учебных пособий. Казалось бы, с этим все хорошо. Много учебников, утвержденных Министерством образования и науки РФ, но они зачастую отдалены от учебного процесса. Возьмите примерную программу ОБЖ для 5-9 классов, соответствующую ФГОС. Вопросы пожарной безопасности, изучаемые в 5 классе; может кто-то найдет их содержание в учебниках для 5 класса? Такое же состояние и в высшем педагогическом образовании. Самостоятельность образовательных организаций в определении основной образовательной программы все-таки должна еще и поддерживаться административным ресурсом, регулирующим эту деятельность. Как можно это осуществить, если нигде в органах управления образованием нет специалиста, способного это организовать. Например, учебно-методическое объединение в Российском государственном педагогическом университете им. А. И. Герцена и учебно-методическое объединение Московского педагогического государственного университета стоят на разных позициях и, наверное, никогда не будут иметь единого мнения. 
Вот и остались мы со своими проблемами наедине. Учитель с учащимся; декан со студентами и т. д. Каждый пытается справиться по-своему. А чиновники, издав стандарты, остаются сторонними наблюдателями и проверяющими. Мы же на «передовой» педагогического образования.

Получается, мы начинаем все сначала, как было 20 лет назад - населению и педагогическим работникам нужны грамотные и полезные для общества люди, а чиновники снова поставили нам задачи и остались в стороне. Хотя уже в некоторых регионах находится взаимопонимание благодаря МЧС РФ.

Свердловская область в этой трудной работе имеет свои успехи и опыт развития регионального образования по новому стандарту. Например, в лицее № 110 г. Екатеринбурга: «Окружающий мир» - в 3 и 4 классах, ОБЖ - в 5, 8 и т. д. Формирование культуры не может быть с перерывами, оно должно быть непрерывным в учебной и внеклассной деятельности. Мы работаем по региональным программам (1992 г., 2006 г.), где бюджет учебного времени составлял - 400 часов с 1 по 11 классы. А по ФГОС, оказывается, времени не хватает! Общеизвестно выражение: «Добрая школа - хорошо, умная школа - великолепно, но ребенок должен быть подготовлен к жизни». Цель школы сейчас подготовить выпускника к ЕГЭ, а родителей - чтобы ребенок поступил в вуз, неважно куда, лишь бы получить высшее образование.

Мы ведь с вами имеем государственную позицию и, наверное, все-таки убеждением и методическим руководством способны, хотя бы каждый на региональном уровне, попробовать исправить ситуацию. В России в каждом федеральном округе есть центры по развитию преподавания в области безопасности жизнедеятельности. В чем заключается эта работа? Мы в Уральском государственном педагогическом университете на факультете безопасности жизнедеятельности осуществили следующее:

- разработали образовательную концепцию предмета ОБЖ для образовательных учреждений Свердловской области;

- организовали встречу по этому вопросу с руководством Министерства образования области - нас только услышали, а поддержки мы не получили, т. к. нет финансирования;

- организовали с несколькими директорами школ встречи и разъяснительную работу - ровно 80 \% школ нас поддержали;

- начали разработку новой региональной программы по ОБЖ, определили направления.

Эту работу ведет Уральский региональный учебно-методический центр по развитию преподавания в области безопасности жизнедеятельности (в его составе директор и два специалиста по учебно-методической работе). Активную работу ведет вновь созданная научная школа безопасности жизнедеятельности, которая зарегистрирована в академии естественных наук и имеет сертификат соответствия. Научную деятельность школы возглавляет доктор педагогических наук, профессор В. Д. Ширшов. Опробовав эту деятельность в своем регионе, мы действительно готовы к выходу за рамки области, а именно в Челябинскую, Курганскую, Тюменскую области. Хотя уже в некоторых вопросах мы имеем их поддержку.

И вот на основании объема знаний и компетенций учащихся мы планируем создать портрет студента-выпускника, определив его знания и компетенции, способность к педагогической работе по формированию полезного человека для общества. Правда, тут нам все время встречаются трудности. Работали по одному стандарту, появился другой. Пытаемся сами создать профессиональный 
стандарт учителя безопасности жизнедеятельности. Не тот, что определяют сверху, а приближенный к образованию. Учитель должен быть подготовлен одинаково к профессиональной деятельности. Он ведь и в Екатеринбурге, и в Новосибирске, и в Хабаровске, и в Москве выполняет одну и ту же миссию.

Таким образом, объединившись, мы можем без помощи чиновников, в своих регионах, организовать нормативную деятельность по формированию единого образовательного пространства культуры безопасности в России, выполнив требования ФГОС общего образования и ФГОС ВПО по безопасности жизнедеятельности, что не выпол- нила ранее созданная Ассоциация специалистов в области безопасности жизнедеятельности, возглавляемая Л. И. Шершнёвым. Большая работа в методическом руководстве выполняется и в вашем университете, она заслуживает высокой оценки.

Каждая образовательная область имеет свою научную основу, устоявшуюся программу обучения в школе и в вузе, учебники и учебные пособия по этим программам, безопасность жизнедеятельности не должна стать исключением. Считаем, что общими усилиями мы также можем решить и эти вопросы. Ведь перед нами стоит государственная задача.

\section{СПИСОК ЛИТЕРАТУРЫ}

1. Мельникова Н. Ф. Теория и методика обучения безопасности жизнедеятельности: уч. пособие; Урал. гос. пед. ун-т. - Екатеринбург, 2011. - 140 с.

2. Репин Ю. В. Безопасность и защита человека в чрезвычайных ситуациях: уч. пособие для студентов пед. вузов. М.: Дрофа, 2005. - 191 с.

3. Гафнер В. В. Культура безопасности: аналитический обзор диссертационных исследований (педагогические науки, 2002-2012 гг.). Урал. гос. пед. ун-т. - Екатеринбург, 2013. - 200 с.

4. Образовательная концепция предмета «Основы безопасности жизнедеятельности» для образовательных организаций общего образования Свердловской области / Авт.-сост. Репин Ю. В., Ширшов В. Д., Гафнер В. В. - Урал. гос. пед. ун-т. - Екатеринбург, 2014. - 25 с.

5. Ширшов В. Д., Репин Ю. В. Создание научно-педагогической школы «Образовательный кластер формирования культуры безопасности» // Педагогическое образование в России. № 2. - 2014. - С. 124-128.

6. Ширшов В. Д. Духовно-нравственное воспитание: уч. пособие. Урал. гос. пед. ун-т. - Екатеринбург, 2013. - 222 с.

7. Репин Ю. В. ОБЖ - фундамент качественного образования // Педагогическое образование в России. - № 1. - 2012. - С. 119-126.

8. Репин Ю. В. Индивидуальный проект школьника // ОБЖ. Основы безопасности жизни. № 6. - 2011.

9. Репин Ю. В. Подготовка бакалавров в области безопасности жизнедеятельности // ОБЖ. Основы безопасности жизни. - № 7. - 2011.

10. Репин Ю. В. Магистерская программа в действии // ОБЖ. Основы безопасности жизни. № 7. -2011. 
DOI: $10.15293 / 2226-3365.1405$

Repin Yuri Viktorovich, Candidate of Pedagogical Sciences, Professor, Dean of the Faculty of Safety, Ural State Pedagogical University, Honorary Worker of Higher Professional Education of Russian Federation, Full Member of Academy of Sciences of Ecology, Man and Nature, Yekaterinburg, Russian Federation.

E-mail: repin19502706@mail.ru

\title{
CURRENT STATUS OF THE PROBLEM OF FORMATION OF CULTURE OF SAFETY IN EDUCATIONAL INSTITUTIONS OF SECONDARY AND HIGHER EDUCATION
}

\begin{abstract}
The article analyzes the main problems of development of the main subject "Basics of life safety" in the General education system that need to be addressed by educational institutions, education authorities on the implementation in the educational process of the Federal state educational standards of primary and secondary education. It is noted that in modern conditions it is necessary to pay serious attention to the creation of a culture of safety the younger generation. The article highlights the main areas of teacher preparation, safety - teachers of the XXI century, able to teach and convince the younger generation in compliance with the rules of modern life, maintaining a healthy and safe lifestyle, paying particular attention to personal and public safety. The conclusions are issues of development and implementation in the educational process unified the main educational program of training of students of pedagogical universities on the profile of "safety" that is acceptable in all regions of Russia, as well as making proposals for project development of professional standards for teachers of safety.
\end{abstract}

\section{Keywords}

subject "Basics of life safety", the teacher of life safety, healthy and safe lifestyle, educational cluster safety

\section{REFERENCES}

1. Melnikova N. F. The Theory and methods of teaching life safety. Manual. Ekaterinburg, 2011, 140 p. (In Russian)

2. Repin Y. V. Security and protection of human rights in emergency situations. Manual for students of the Institute. Moscow, Drofa Publ., 2005, 191 p. (In Russian)

3. Gafner V. V. Safety Culture: analytical review of dissertation research (pedagogical science, 2002-2012). Ekaterinburg, 2013, 200 p. (In Russian)

4. The educational concept of the subject "Basics of life safety" for educational institutions of General education of Sverdlovsk region. (Ed.) Repin Y. C., Shirshov C. D., Gafner V. V. Ekaterinburg, 2014, 25 p. (In Russian)

5. Shirshov V. D., Repin Y. V. The Creation of scientific-pedagogical school "Educational cluster formation safety culture”. Pedagogical education in Russia. no. 2, 2014, pp. 124-128. (In Russian)

6. Shirshov V. D. Spiritually-moral education. Textbook. Ekaterinburg, 2013, 222 p. (In Russian)

7. Repin Y. V. Life safety - the Foundation of quality education. Pedagogical education in Russia. no. 1, 2012, pp. 119-126. (In Russian) 
8. Repin Y. V. Individual project student. Life safety. The basics of life security. no. 6, 2011. (In Russian)

9. Repin Y. V. Preparation of bachelors in the field of security of life. Life safety. The basics of life security. no. 7, 2011. (In Russian)

10. Repin Y. V. Individual student project. Life safety. The basics of life security. no. 7, 2011. (In Russian) 


\title{
К ВОПРОСУ ПОДГОТОВКИ СПЕЦИАЛИСТОВ ПО ОРГАНИЗАЦИИ АНТИНАРКОТИЧЕСКОЙ ПРОФИЛАКТИЧЕСКОЙ РАБОТЫ В ОБРАЗОВАТЕЛЬНОЙ СРЕДЕ
}

\section{3. А. Хуснутдинова (Уфа, Россия)}

\begin{abstract}
Цель статьи выделить и охарактеризовать основные проблемы, существующче в системе высшего образования, способствующие наркотизации студенческой молодежи и требуюшчие незамедлительного их решения. По разным данным от 12 до 30 \% российских студентов имеют опыт употребления различных видов психоактивных вещчеств (ПАВ). Важным элементом в общей системе предупреждения употребления ПАВ несовершеннолетними и молодежью и формирования здорового образа жизни в обществе является организация первичной профилактической работь в образовательной среде, включающая педагогчческую профилактику. Данной работе препятствует отсутствие подготовленных специилистов - организаторов профилактической работы в образовательных организациях. Подготовка таких специалистов ведется в Башкирском государственном педагогическом университете им. М. Акмулль по магистерской программе «Профилактика сочиальных отклонений (превентология)». Однако не решенным остается вопрос трудоустройства превентологов из-за отсутствия такой должности в Общероссийском классификаторе профессий рабочих, должностей служаших.
\end{abstract}

Ключевые слова: антинаркотическая профилактическая работа, образовательная среда, педагогическая профилактика, студенты, превентологи.

Конечный фундаментальный смысл современной антинаркотической политики сбережение народа. Данное положение напрямую вытекает из анализа сложившейся ситуации в стране. Масштабы наркотрагедии в стране являются поистине устрашающими. По информации НИЦ наркологии более 70 \% лиц, состоящих на учете в специализированных наркологических учреждениях, составляют молодые люди в возрасте до 30 лет. По данным Центра социологических исследований в 2010 году в возрастной группе 11-24 года, опыт употребления наркотиков имеют порядка $13 \%$ российских граждан (18 млн человек), а численность регулярно потребляющих наркотики (с частотой не реже 2-3 раз в месяц) составляла 9,6 \% от общей численности данной возрастной группы (2,6 млн человек).

\footnotetext{
Хуснутдинова Золя Аслямовна - доктор медицинских наук, профессор, заведующий кафедрой охраны здоровья и безопасности жизнедеятельности, Башкирский государственный педагогический университет им. М. Акмуллы.

E-mail: zoly50@mail.ru
} 
Удельный вес потребляющих алкогольные напитки, включая пиво, составил 50,5 \% несовершеннолетних и молодежи или 13,7 млн человек, а курящих табачные изделия - 45,6 \% (12,3 млн человек).

Широкий спрос на наркотики, помимо формирования высокой смертности среди молодёжи и существенного влияния на здоровье населения, во многом формирует криминогенную обстановку в стране, что создает угрозу национальной безопасности и социально-экономическому развитию страны. По данным правоохранительных органов, 49 \% лиц, совершивших в 2010 году преступления, связанные с незаконным оборотом наркотиков, являются молодыми людьми возрасте от 14 до 30 лет. По экспертным оценкам, каждое десятое преступление данной категории совершается в состоянии наркотического опьянения ${ }^{1}$.

Наркомания приобрела характер эпидемии. По статистике каждый наркопотребитель - это автономный источник, инструмент социального инфицирования наркоманией своего окружения - от 3 до 5 человек ежегодно.

В данной ситуации абсолютно недостаточно заниматься полицейской работой и информированием людей - пугать их страшными последствиями наркомании. Проблема лежит гораздо глубже. Представления о природе аддиктивного (зависимого) поведения развивались параллельно с развитием культуры и до сих пор не могут считаться исчерпывающими [1]. На сегодня приоритет отдается комплексной - биопсихосоциодуховной модели аддиктивного поведения, рассматривающей зависимость как следствие нарушений в функционировании сложной многоуров-

${ }^{1}$ Статистика распространения наркомании в России в 2000-2010 гг. Справка [Электронный ресурс]. Режим доступа: невой системы «социум - личность - организм» [2]. Это значит, что аддиктивное поведение должно одновременно рассматриваться в нескольких планах: культурологическом, социальном, правовом, психологическом, медико-биологическом. Именно эта модель, обеспечивающая системный подход к проблеме, позволяет специалистам разного профиля найти свое место в профилактике наркомании. Причины аддиктивного поведения подрастающего поколения по-разному распределены в городах и провинции. В мегаполисах наблюдается их поливариантность. Инвариантом причин приобщения к наркомании можно считать влияние двух групп - семьи и групп ровесников [3]. Влияние микросреды (ближайшего окружения индивида), куда, безусловно, включаются близкие родственники с индивидуально присущими социально-психологическими характеристиками, аддиктивность их поведения, в том числе их алкоголизация, в ряде случаев являются основным патогенным фактором в генезе наркологических заболеваний [4].

Немедицинское распространение наркотиков проникло во все сферы общества, включая учреждения высшего профессионального образования. По данным различных исследователей, удельный вес наркопотребителей среди студентов вузов составляет 12-16 \% от всей студенческой молодежи, а по заявлению на одной из пресс-конференций главного нарколога Министерства здравоохранения России Е. Брюна сегодня до 30 \% российских

http://www.rian.ru/spravka/20100422/2254386 45.html. 
студентов имеют опыт употребления наркотиков $^{2}$.

Сами студенты, оценивая наркотическую ситуацию в вузах, ставят проблему наркомании и нехимической зависимости на третье место в рейтинге актуальных проблем современной молодежи ( $35 \%$ ответов), опережая проблемы, связанные с обучением, трудоустройством и здоровьем [5]. В этих условиях, очевидно, назрела необходимость перехода к новой комплексной антинаркотической модели, доминанта которой ориентирована, прежде всего, на борьбу со спросом на наркотики в молодежной среде, в том числе в условиях образовательных учреждений [6].

В Стратегии государственной антинаркотической политики Российской Федерации до 2020 года отмечено, что одной из основных проблем, влияющих на эффективность государственной антинаркотической политики, является низкий уровень организации первичной профилактики, хотя профилактическая работа в России осуществляется на всех уровнях образования - от дошкольного до высшего профессионального ${ }^{3}$. Однако, к сожалению, множество предпринимаемых сегодня мероприятий в области профилактики наркозависимостей на различных уровнях не приносят желаемого результата.

Данные международных исследований на примерах реализации программ профилактики показывают, что профилактическая работа наиболее эффективна внутри местного сообщества, каковым традиционно для детей и молодежи является образовательное учреждение (одновременно являясь и зоной риска).

${ }^{2}$ Минздрав: Употребляющих наркотики школьников не будут ставить на медучет: [Электронный ресурс]. Режим доступа: http://www.vz.ru/news/2011/9/7/520553.html.

${ }^{3}$ Стратегия государственной антинаркотической политики Российской Федерации до 2020
Профилактика в образовательной среде является важным компонентом общей системы предупреждения употребления психически активных веществ (ПАВ) несовершеннолетними и молодежью и формирования здорового образа жизни в обществе ${ }^{4}$. Как отмечено в Концепции профилактики употребления психоактивных веществ в образовательной среде цель профилактики в образовательной среде - развитие на постоянной основе инфраструктуры и содержания профилактической деятельности, направленной на минимизацию уровня вовлеченности в употребление ПАВ обучающихся, воспитанников путем развития личностных, социально-средовых и этико-правовых ресурсов.

Профилактика аддиктивного поведения учащейся молодежи должна быть направлена на формирование установки личности на избегание первичного приема психоактивных веществ, решение которой возможно, прежде всего, педагогическими технологиями, которые направлены на формирование у обучающихся, воспитанников представлений, норм поведения, оценок, снижающих риск приобщения к психоактивных веществ, а также на развитие личностных ресурсов, обеспечивающих эффективную социальную адаптацию.

Стратегическим приоритетом профилактических мероприятий следует рассматривать создание системы позитивной профилактики, которая ориентируется не на патологию, не на проблему и ее последствия, а воспитание психически здорового и личностно развитого человека, способного самостоятельно справ-

года. Утв. Указом Президента Российской Федерации N 690 от 9 июня 2010 года.

${ }^{4}$ Письмо Минобрнауки РФ от 05 сентября 2011 г. N МД-1197/06 "О Концепции профилактики употребления психоактивных веществ в образовательной среде" [Текст]. М., 2011. 
Вестник Новосибирского государственного педагогического университета

5(21)2014 www.vestnik.nspu.ru

ISSN 2226-3365

ляться с собственными психологическими затруднениями и жизненными проблемами, не нуждающегося в приеме ПАВ, т.е. личности безопасного типа поведения [7]. Потому в воспитательной деятельности образовательных учреждений актуализируется задача формирования здорового образа жизни.

Главным содержанием первичной профилактики в образовательной среде является педагогическая профилактика. Она представляет собой комплексную систему организации процесса обучения и воспитания детей и молодежи, обеспечивающую снижение риска употребления ПАВ за счет расширения социальных компетенций, формирования личностных свойств и качеств, повышающих устойчивость к негативным влияниям среды. Однако на сегодня в системе образования сохраняется дефицит педагогических и управленческих кадров, обладающих необходимой квалификацией для организации полноценной профилактической работы с использованием вышеперечисленных технологий. Решение проблемы подготовки кадров должно осуществляться в рамках профессионального и послевузовского профессионального образования [8-9].

К сожалению, мониторинг принятых на различных уровнях решений по обсуждаемой проблеме показывает, что до сих пор важнейший системный вопрос - вопрос подготовки кадров для антинаркотической деятельности обходится стороной. Как в целом по России, так и в Башкортостане, до сих пор не создана система целевой подготовки педагогических кадров для работы с наркозависимыми лицами, среди которых подавляющее большинство - молодежь. Большинство педагогических работников образовательных учреждений признают свою неосведомленность в области предупреждения и коррекции аддиктивного поведения у детей и молодежи. В системе повышения квалификации педагогических кадров и иных работников социальной сферы представлено минимальное количество курсов, ориентированных на профилактику наркомании в молодежной среде, и практически отсутствуют специальные учебные программы [10-11].

Первичная и базовая подготовка специалистов образовательной сферы по профилактике употребления ПАВ несовершеннолетними и молодежью должна иметь такую структуру подготовки специалистов, которая была бы направлена на окончательный отказ от сохранившегося до настоящего времени информационно-образовательного подхода, имеющего низкую эффективность.

Башкирский государственный педагогический университет имени М. Акмуллы, как социальный институт, обладает рядом возможностей для организации антинаркотической профилактической работы. В частности, вуз имеет достаточный опыт в решении образовательных задач в сфере профилактики различных социальных отклонений, в том числе наркомании, в подготовке конкурентоспособных специалистов. Так, с 2011/2012 учебного года в соответствии с решением АНК Республики Башкортостан, утвержденного протоколом № 17 от 14 июня 2011 года в БГПУ им. М. Акмуллы начата подготовка специалистов по организации профилактической работы по образовательной программе «Профилактика социальных отклонений» - магистров-превентологов. На сегодня осуществлено два выпуска таких специалистов. Однако мы столкнулись с другой сложностью - трудоустройство в соответствии с их уровнем квалификации. Данное явление объясняется не только нерешенностью в целом по стране статусом магистра, но и отсутствием в Общероссийском классификаторе профессий рабочих, 
должностей служащих должности превентолога, хотя в отдельных субъектах России, в частности в Москве, данная проблема решена на уровне местного правительства по инициативе УФСКН России по г. Москва.

На заседании АНК в сентябре сего года мы инициировали вопрос с трудоустройством превентологов. Было принято решение рассмотреть данный вопрос на межведомственной основе, а также выйти с ходатайством перед Министерством труда и социальной защиты России о включении должности «превентолог» в Общероссийский классификатор.

Высшая школа и другие социальные институты, занимающиеся проблемами воспитания и предупреждения асоциального поведения, ставят своей целью, не только формирование общекультурных качеств, но и формирование установок на сохранение здоровья и здоровый образ жизни. В связи с последним, на заседании АНК Республики Башкортостан также принято решение о включении в основные и дополнительные образовательные программы не только педагогических вузов, но и всех учреждений высшего и среднего профессионального образования, специальных дисциплин и разделов по профилактике употребления психоактивных веществ. Это является, как отмечено в Стратегии государственной антинаркотической политики Российской Федерации до 2020 года, одним из предпочтительных направлений антинаркотической деятельности. Такая практика осуществляется в нашем вузе. В учебных планах образовательных программ всех профилей и направлений предусмотрена специальная дисциплина «Профилактика аддиктивного поведения», а для студентов профиля «Безопасность жизнедеятельности» - дисциплина «Реабилитация зависимых личностей».
Резюмируя изложенное, еще раз следует подчеркнуть, что на сегодня в системе высшего образования, существует целый ряд проблем, способствующих наркотизации студенческой молодежи и требующих незамедлительного решения:

- образовательные учреждения по-прежнему остаются одними из мест распространения наркотиков и приобщения детей и молодежи к их употреблению;

- в системе образования сохраняется дефицит педагогических и управленческих кадров, обладающих необходимой квалификацией для организации полноценной профилактической работы;

просветительский подход в профилактике, когда профилактическая работа обеспечивается за счет регулярных, но недостаточно эффективных мероприятий (чтение лекций, проведение антинаркотических акций, конкурсов плакатов, рисунков);

- нуждается в улучшении организация индивидуальной профилактической работы с молодыми людьми, включая обеспечение доступности программ отдыха, оздоровления и занятости, а также реабилитационных программ;

- в профилактической работе недостаточно используется воспитательный потенциал родителей обучающихся и т. д.

Таким образом, учитывая сложившуюся наркотическую ситуацию в молодежной среде, необходимо выработать новые подходы к борьбе с наркоманией, куда были бы интегрированы все лучшие практики в сферах медицины, педагогики, психологии, социальной и духовной работы. Эффективность антинаркотической деятельности достижима лишь при её системной организации и с участием всего общества. 


\section{СПИСОК ЛИТЕРАТУРЫ}

1. Короленко Ц. П., Дмитриева Н. В. Факторы, способствующие развитию химических аддикций // Психологические и социокультурные аспекты профилактики нарко-алкогольной зависимости: сб. науч. работ / под. ред. М. С. Яницкого. - Кемерово, 2000. - С. 88-97.

2. Руководство по аддиктологии / под ред. проф. В. Д. Менделевича. - СПб: Речь, 2007. - 768 с.

3. Джексимбекова Л. К. Молодежные наркомании в Республике Калмыкия (Опыт социологического анализа): автореф. дис. ... канд. мед. наук. - Волгоград, 2003. - 22 с.

4. Хуснутдинова 3. А., Туляков М. Д. Медико-социальная и индивидуально-психологическая характеристика подростков-наркоманов и их здоровых сибсов // Бюллетень ВСНЦ СО РАMH.-2013.- № 3 (91). - Ч. 1. - С. 126-130.

5. Бохан Н. А. Как обойти смертельную опасность? Проблемы мониторинга и перспективы профилактики наркомании в вузах // Медицинская газета. - М., 2011. - № 78.

6. Пономарев А. В., Лопаева Н. С. Модель организации первичной профилактики наркомании в УГТУ-УПИ // Организация антинаркотической профилактической работы в студенческой среде: сборник научно-методических статей и материалов. - Казань, 2008. - С. 19-36.

7. Михайлов Л. А., Корчагина Г. А., Шатрова О. В. Единый комплексный подход: реабилитация - профессионализация - трудоустройство - социальное сопровождение несовершеннолетних, прошедших лечение от наркозависимости в рамках антинаркотических региональных программ: метод. пособие / под ред. В. П. Соломина. - СПб: Изд-во РГПУ им. А. И. Герцена, 2004. - 139 с.

8. Модель подготовки специалиста по профилактике наркоманий в системе высшего профессионального образования: учебные программы / под науч. ред. Л. М. Шипициной. - СПб: Образование - Культура, 2003. - 216 с.

9. Хуснутдинова 3. А. Необходимы подготовленные специалисты // Не будь зависим. - № 11. - 2012. - C. 54-55.

10. Хуснутдинова 3. А., Евлентьев Д. С. Современные проблемы профилактики наркотизации студенческой молодежи // Педагогический журнал Башкортостана. - № 1 (44). - 2013. С. $158-164$

11. Хасан Б. И., Дюндик Н. Н., Федоренко Е. К., Кухаренко И. А., Привалихина Т. И. Образование в области профилактики наркозависимости и других аддикций: организационно-методич. пособие. - Красноярск: Красноярск. гос. ун-т., 2003. - 335 с. 
DOI: $10.15293 / 2226-3365.1405$

Khusnutdinova Zolya Asliamovna, Doctor of Medical Sciences, Professor, Head of Department of Health and Safety, M. Akmulla Bashir State Pedagogical University, Ufa, Russian Federation. E-mail: zoly50@mail.ru

\title{
TRAINING OF SPECIALISTS ON ORGANIZATION OF ANTI-NARCOTIC PROPHYLACTICS WITHIN THE EDUCATIONAL MEDIA
}

\begin{abstract}
Purpose of this article is to allocate and characterize main problems existing in the system of higher education, which contribute to narcotization of students and demand immediate decision. According to different studies from 12 to $30 \%$ of Russian students have experience in use of various psychoactive substances. An important element in the general system of drug use prevention and formation of a healthy lifestyle attitude among minors is the organization of primary prophylactics including pedagogical prevention. It is interfered by the absence of trained staff - organizers of prevention work in the educational organizations. Training of such experts is conducted at the M. Akmulla Bashkir State Pedagogical University according to the magister program "Prevention of Social Deviations (Preventology)". However, question of employment of these professionals is not solved due to the absence of such position in the Russian qualifier of professions of workers, positions of employees.
\end{abstract}

\section{Keywords}

drug-abuse prophylactic work, educational media, pedagogical prophylactics, students, preventologists

\section{REFERENCES}

1. Korolenko Ts. P., Dmitrieva N. V. Factors inducing chemical addictions. Psychological and sociocultural aspects of alcohol and drug addiction prophylactics: science work digest. (Ed.) M. S. Yanitskii. Kemerovo, 2000, pp. 88-97. (In Russian)

2. Manual of addictology. Ed. V. D. Mendelevych. St. Petersburg, the Speech Publ., 2007, 768 p. (In Russian)

3. Jeksimbekova L. K. Youth drug addictions is Republic of Kalmykiya. Social study experience. Volgograd, 2003, 22 p. (In Russian)

4. Khusnutdinova Z. A., Tylyakov M. D. Medical-social and individual psychological characteristics of drug addicted kids and their healthy relatives. Bulletin Of Eastern-Siberian Scientific Center. 2013, no. 3 (91), vol. 1, pp. 126-130. (In Russian)

5. Bokhan N. A. How to evade lethal danger? Problems of monitoring and perspectives of prophylactics of drug addiction in higher education institutions. Medical newspaper. Moscow, 2011, no. 78. (In Russian)

6. Ponomarev A. V., Lopaeva N. S. Primary prophylactics organization model UGTU-UPI. Organization of anti-narcotic prophylactic work among students. Digest of sci.-methodic. works and articles. Kazan, 2008, pp. 19-36. (In Russian) 
7. Mikhailov L. A., Korchagina G. A., Shatrova O. V. United complex approach: rehabilitation - professionalization - employment - social escort of the minors who passed treatment from drug addiction within anti-narcotic regional programs: methodical textbook. (Ed.) V. P. Solomin. St. Petersburg, A. I. Gercen RGPU Publ., 2004, 139 p. (In Russian)

8. Training model of drug abuse prophylactics specialists in the field of higher professional education. Educational programs. Sci. editor L. M. Shipitsina. St. Petersburg, Education. Culture Publ., 2003, 216 p. (In Russian)

9. Khusnutdinova Z. A. In need of trained specialists. Don't be addicted. no. 11, 2012, pp. 54-55. (In Russian)

10. Khusnutdinova Z. A., Evlentiev D. S. Modern problems of narcotization prophylactics among student youth. Pedagogical magazine of Bashkortostan. no. 1 (44), 2013, pp. 158-164. (In Russian)

11. Khassan B. I., Djundik N. N., Fedorenko E. K., Kukharenko I. A., Prevalikhina T. I. Education in the field of prophylactics of drug and other addictions. Organization methodical textbook. Krasnoyarsk, Krasnoyarsk State University Publ., 2003, 335 p. (In Russian) 
УДК 372.016:614.8 + 371

\title{
НАИБОЛЕЕ АКТУАЛЬНЫЕ ПРОБЛЕМЫ ПРЕПОДАВАНИЯ ПРЕДМЕТА ОБЖ В СВЕТЕ ТРЕБОВАНИЙ ФГОС
}

\author{
А. М. Зуев (Сергиев Посад, Россия)
}

В статье анализируются основные проблемы преподавания предмета ОБЖ в свете требований ФГОС. Цель статьи - выделить и охарактеризовать основные проблемы преподавания ОБЖ в школе на современном уровне развития образования. Отмечается, что в современных условиях обучения ОБЖ можно выделить пять основных проблем: первая касается организачии и проведения занятий по чрезвычайным ситуачиям природного и техногенного характера; вторая - пересмотра содержания по разделу обеспечения безопасности дорожного движения; третья - внедрения информационно-коммуникаиионных технологий; четвертая методов работы, которые должны быть практико-ориентированными, познавательными; и пятая - летние сборы необходимо проводить в специально созданных при действующих войсковых частях региональных учебных центрах. ФГОС нового поколения ставит перед преподавателями ОБЖ важные и серьёзные задачи опережающего качественного обучения учащихся и студентов.

Ключевые слова: ФГОС, проблемы преподавания ОБЖ, современные условия обучения, методы работы, организачия и проведение занятий.

Выпускники учреждений среднего профессионального образования (СПО) кроме специальной подготовки должны освоить общепрофессиональную дисциплину «Основы безопасности жизнедеятельности» (ОБЖ). Новые требования ФГОС ставят перед преподавателем ряд проблем по обеспечению качественного обучения учащихся и студентов, в целом [2, 7], по предмету ОБЖ, - в частности [1, 3-4].

\section{Первая проблема}

На уроках по чрезвычайным ситуациям (ЧС) природного и техногенного характера необходимо, чтобы студенты поняли, что безопасность человека во многом зависит от уровня культуры безопасности, т. е. осведомленности о возможных бедствиях, правилах действий в ЧС, готовности противостоять опасностям, которые подстерегают нас в природе, в городских условиях - повсюду, где мы живем, трудимся, отдыхаем. Необходимо осознавать, что оценки по ним выставляет жизнь и «пятерка» - это спасение, а «двойка» - беда.

Зуев Алексей Михайлович - кандидат технических наук, почётный работник среднего профессионального образования РФ, преподаватель ОБЖ, Московский областной профессиональный колледж.

E-mail: mopk@spnet.ru 
Организацию и проведение занятий по ЧС природного и техногенного характера, выбор форм, методов и средств обучения необходимо осуществлять исходя из специфики содержания изучаемых тем, возрастных особенностей и учёта для данного района негативного характера природных явлений и наличия опасных производств в регионе.

Основным вкладом предмета ОБЖ в достижение целей ФГОС становится формирование у студентов умения применять полученные знания в повседневной жизни для объяснения, оценки и прогнозирования разнообразных природных, социальноэкономических и экологических процессов и явлений, приобретение опыта адаптации к условиям окружающей среды, экологически сообразного поведения в ней и обеспечения безопасности.

Перечислим основные ЧС природного и техногенного характера, присущие для Подмосковья: метеорологические и гидрологические опасные явления, лесные и торфяные пожары, аварии с выбросом радиоактивных и химических опасных веществ. В частности, при анализе конкретного ситуационного задания на уроке, например, с возможным разливом радиоактивных отходов в городе при транспортировке до места захоронения в организацию «Радон» позволяет в ходе обсуждения выработать студентам безопасные действия. Полезны для рассмотрения ситуационные задания - аварии на объектах, использующих хлор в пос. Скоропусковский или аммиак в дер. Наугольное с целью проверки действий обучающихся: остаются на месте в кабинете ОБЖ на втором этаже, поднимаются на четвертый этаж или опускаются в подвал.

Гражданская оборона - раздел программы ОБЖ для подробного изучения всех шести поражающих факторов ядерного взрыва, включая электромагнитный импульс и сейсмовзрывные волны. Уроки Чернобыля, Фукусимы должны нас учить правильным действиям в подобных ситуациях в мирное время. Контроль знаний безопасных действий осуществляется через составление синквейна, решение типовых задач и тестирование. Изучение дезактивации, дегазации и дезинфекции обязательно проводится с привлечением знаний из области химии, физики, математики.

\section{Вторая проблема}

Одной из основных задач современности стало обеспечение безопасности дорожного движения. Около 75 \% всех аварий на автомобильном транспорте происходит из-за нарушения водителями правил дорожного движения. Особенность дорожнотранспортного происшествия (ДТП) состоит в том, что $80 \%$ раненых погибает в первые три часа из-за обильных кровопотерь, т. к. подготовка инспекторов ГИБДД, населения и водителей в оказании первой медицинской помощи оставляет желать лучшего. Вот почему смертность от ДТП В России в 10-15 раз выше, чем во всём мире. Перед выходом студентов на практические занятия по вождению мы проводим факультативное практическое занятие по теме «Безопасная езда на автомобиле», включая анализ причин ДТП, тормозных качеств, условий заноса и опрокидывания транспортного средства [5-6].

Своевременно оказанная и правильно проведенная первая помощь подчас не только спасает жизнь пострадавшему, но и обеспечивает его дальнейшее успешное лечение, предупреждает развитие тяжелых осложнений. Эффективность помощи оценивается по величине предотвращения смертности: если ее оказывают через 30 мин. после воздействия, то осложнения уменьшаются в два раза, через один час осложнения уменьшаются на 30 \%. А сколько зрителей в это время сто- 
ит около пострадавшего и беспомощно переминается с ноги на ногу? Большинство!

В конечном счёте, роль предмета ОБЖ в ближайшем будущем (по ФГОС нового поколения) - владение практическими навыками по оказанию первой помощи пострадавшим всеми выпускниками образовательного учреждения: потеря сознания, обильное кровотечение, отсутствие дыхания, переломы конечностей и т. п. Напрашивается вопрос: «Где эти навыки приобретать?» В связи с этим, мы считаем необходимым обратиться к Министерству образования и науки РФ с предложениями. Для выполнения требований стандартов ФГОС нового поколения необходимо централизованно обеспечить кабинеть ОБЖ всех образовательных учреждений техническими и информационными средствами обучения - робот-тренажёр «Витим» или «Илюша» с соответствующим программным обеспечением, что позволит выпускнику образовательного учреждения наряду с дипломом получить удостоверение о праве оказания первой медицинской помощи (например, выдача ГИБДД прав автовладельцам) ${ }^{1}$.

\section{Третья проблема}

Еще один аспект изменений в практике преподавания - это готовность преподавателя к широкому внедрению информационнокоммуникативных технологий, работа с электронными продуктами. Издательство «Просвещение» перешло на выпуск учебников с электронным приложением, потому что этого требует ФГОС. Переход на новый стандарт осложнен тем, что часть преподавателей слабо владеет ИКТ. А у молодых учителей

\footnotetext{
${ }^{1} \mathrm{C}$ полным перечнем учебного оборудования и технических средств обучения по предмету ОБЖ можно познакомиться на сайте www.fondedinstvo.ru
}

наблюдается бездумное, бессистемное использование компьютерных технологий.

Какие дополнительные возможности для педагогов появляются в связи с развитием информационно-коммуникативных технологий? Это применение в учебном процессе интерактивных моделей природных и общественных явлений и процессов, использование электронных карт, электронных вариантов тестирования и выполнения практических работ, активное использование ресурсов сети Интернет. По ОБЖ таких ресурсов особенно много. Применение компьютера на уроках не дань моде, не способ переложить на него многогранный творческий труд преподавателя, а действенное средство интенсификации образовательного процесса, активизации познавательной деятельности учащихся, повышения их мотивации к изучению ОБЖ и эффективности урока.

\section{Четвёртая проблема}

ФГОС не определяет количество учебных часов по предметам. Поэтому нужно полностью перестраивать методы работы делать их практико-ориентированными, познавательными, переходить на сотрудничество со студентами. Выход один - необходимо ребят заинтересовать, убедить, увлечь. Заинтересовать обучающегося предметом можно через внеаудиторную работу, проектную деятельность, участие в открытых уроках и конференциях, написание рефератов, докладов и др.

Проектная деятельность - это возможность развития способности студентов определять дальнюю и ближнюю перспективу, находить ресурсы, намечать план и достаточно долго удерживать цель действий, оценивать результат, соотносить его с поставленной целью. Проектный тип мышления - это залог дальнейшего успеха в жизни. Учебные проекты по ОБЖ могут готовиться в рамках 
любого курса, при этом их тематика должна быть привязана к изучаемому материалу. По мере освоения содержания и приобретения навыков на изучаемом материале студенты могут разрабатывать самые разнообразные типы проектов: интеллектуальноэвристические, практико-внеаудиторные, ориентированные, творческие, аналитические, исследовательские и т. д.

В МОПК в течение пяти лет функционируют рабочие проекты: «Здоровый образ жизни», «Город - источник опасностей: аварии, криминал, экология», «Военнопатриотическая тематика»; проводятся КВН, заседания клуба знатоков ОБЖ; экскурсии по военно-патриотической тематике в городах Ярославль, Рязань, Москву (музей Вооружённых сил), Бородинское поле с выходом некоторых работ студентов на Всероссийские конкурсы: «Национальное достояние России», «ЮНЭКО», «Меня оценят в ХХІ веке», «Патриот России», 17 наших студентов стали лауреатами [5].

\section{Пятая проблема}

Практика проведения пятидневных летних сборов на базе войсковых частей в соответствии с приказом Министра обороны РФ № 96 и Министерства образования и науки РФ от 24 февраля 2010 года показывает, что в современных условиях войсковые части, количество которых значительно сократилось, отказываются согласовывать программу сборов с образовательными учреждениями, аргументируя тем, что не способны обеспечить выполнение её в необходимом объёме из-за отсутствия кадров, материальной базы, казарменных помещений для размещения студентов в количестве двух рот одновременно.

Летние сборы необходимо проводить в специально созданных при действующих войсковых частях региональных учебных иеентрах
[6]. Количество и места дислокации таких центров должны определить Министерство образования области совместно с Министерством обороны. Сборы целесообразно проводить для всех образовательных учреждений области в течение всего учебного года (по графику). Создание региональных учебных центров позволит: улучшить и скоординировать учебный процесс (главное - его практическую составляющую), упростить и повысить эффективность целевого финансирования; повысить ответственность учебных центров за подготовку допризывников.

Современный во многом формальный процесс проведения летних сборов без создания выездной лагерной атмосферы не устраивает никого. Использование региональных учебных центров позволит превратить данные сборы в действенные практические занятия по подготовке будущих защитников Отечества. Учебно-материальная база для проведения пятидневных учебных сборов на базе региональных учебных центров должна включать: музей боевой славы воинской части; классы тактической подготовки и по общевойсковым уставам; строевой плац, огневая штурмовая полоса и стрельбище (тир); химический и инженерный городок; полигон с тактической полосой; штатная боевая техника и стрелковое оружие с боеприпасами.

За последние годы был принят целый ряд государственных законодательных и нормативных актов, в которых в той или иной степени затронуты вопросы образования в области безопасности и военнопатриотического воспитания подрастающего поколения $^{2}$. И, тем не менее, несмотря на осознание в обществе необходимости формирования культуры безопасности, ещё многие преподаватели жалуются на плохое отноше-

\footnotetext{
${ }^{2}$ Распоряжение Правительства РФ № 134-рг от 03.02.2010 г.
} 
ние к предмету со стороны отдельных руководителей образовательных учреждений и местных чиновников. Качество обучения студентов основам военной службы и безопасности в рамках предмета ОБЖ не может быть высоким без должного финансирования и создания современной учебно-материальной базы, постоянного кадрового обеспечения летних сборов в том числе.
ФГОС нового поколения ставит перед преподавателями ОБЖ важные и серьёзные задачи опережающего качественного обучения учащихся и студентов: от приоритета защиты в сложившихся ситуациях к приоритетному предотвращению этих ситуаций, устранению причин угроз, обеспечению безопасности своей жизнедеятельности, и решать их надо по государственному.

\section{СПИСОК ЛИТЕРАТУРЫ}

1. Айзман Р. И. Здоровье педагогов и обучающихся - ключевая задача современной школы // Вестник Новосибирского государственного педагогического университета - 2012. - № 3. C. 24-35

2. Айзман Р.И., Казин Э.М., Федоров А.И., Шинкаренко А.С. Проблемы и задачи здоровьесберегающей деятельности в системе образования на современном этапе // Вестник Новосибирского государственного педагогического университета - 2014. - № 1. - С. 9-17

3. Айзман Р. И., Королёв В. А. Значение курса «Основы безопасности жизнедеятельности» в современной подготовке школьников // Сибирский педагогический журнал. - 2012. - № 7. C. 210-215.

4. Епоян Т.Г., Плахутина Ю.Б. Фактологический обоснованный подход к профилактическому образованию // Вестник Новосибирского государственного педагогического университета. 2012. - №5. - С. 5-13.

5. Зуев А. М. Проектная деятельность в образовательном процессе // ОБЖ. Основы безопасности жизни. - № 1. - 2014. - С. 36-41.

6. Зуев А. М. Учебные сборы в Сергиев Посадском районе // ОБЖ. Основы безопасности жизни. - № 7. - 2011. - С. 8-11.

7. Смолеусова Т.В. Проблемы реализации требований ФГОС НОО на уроке и внедрение инноваций // Вестник Новосибирского государственного педагогического университета. 2012. - № 6. - C. 5-10. 
Zuev Aleksey Mikhaylovich, Candidate of Technical Sciences, Honorable worker secondary professional education of Russian Federation, Instructor of basics of safety of life, Moscow provincial professional college, Sergiev Posad, Russian Federation.

E-mail: mopk@spnet.ru

\title{
THE VITAL PROBLEMS OF THE TEACHING OF OBJECT BASICS OF SAFETY OF LIFE IN LIGHT OF THE REQUIREMENTS STATE FEDERAL EDUCATIONAL STANDARD
}

\begin{abstract}
In the article are analyzed the basic problems of the teaching of object basics of safety of life in light of the requirements State Federal Educational Standard. Purpose of article - to isolate and to describe the basic problems of the teaching basics of safety of life in the school at the contemporary level of the development of formation. It is noted that under the contemporary conditions for instruction basics of safety of life it is possible to isolate five basic problems: the first problem concerns organization and conducting occupations according to the extraordinary situations of natural and technogenic nature; the second - revision of the content within the division of providing safety of road motion; the third - introduction of information communication line technologies; the fourth - methods of operation must be practice oriented, cognitive and the fifth - summer collections must be carried out in the specially created with the acting troop units regional training centers. State Federal Educational Standard of new generation poses before the instructors of basics of safety of life the important and serious problems of the anticipating qualitative instruction of students and students.
\end{abstract}

\section{Keywords}

State Federal Educational Standard, the problem of teaching basics of safety of life, the contemporary conditions for instruction, methods of operation, organization and conducting occupations

\section{REFERENCES}

1. Aizman R.I. Health of teachers and schoolchildren is a key problem of modern school. Novosibirsk State Pedagogical University Bulletin, 2012, no. 3, pp. 24-35. (In Russian)

2. Aizman R.I., Kazin E.M., Fedorov A.I., Shinkarenko A.S. Problems and aims of health care activity in the education system at the present stage Novosibirsk State Pedagogical University Bulletin, 2014, no. 1, pp. 9-17. (In Russian)

3. Aizman R. I., Korolev V. A. Meaning of course "Basic Life" in the modern preparation of students. Siberian Education Journal. 2012, no. 7, pp. 210-215. (In Russian)

4. Yepoyan T. A., Plahutina Yu. B. The factological proved approach to preventive education and use of information-communication technologies in informal education. Novosibirsk State Pedagogical University Bulletin, 2012, no. 5, pp. 5-13. (In Russian)

5. Zuev A. M. Design activity in the educational process. Bases of Life Safety, no.1, 2014, pp. 36-41. (In Russian) 
6. Zuev A.M. The training assemblies in Sergius Posadskiy region. Bases of Life Safety, no.7, 2011, pp. 8-11. (In Russian)

7. Smoleusova T.V. Problems of implementation of the requirements of Federal State Educational Standards primary education in class and innovation. Novosibirsk State Pedagogical University Bulletin, 2012, no. 6, pp. 5-10. (In Russian) 


\title{
УДК 37.014.3
}

\section{АКТУАЛЬНЫЕ ВОПРОСЫ ВНЕДРЕНИЯ ФГОС}

\author{
Т. В. Смолеусова (Новосибирск, Россия)
}

\begin{abstract}
В статье проанализированы актуальные вопросы четвертого года внедрения требований федерального государственного образовательного стандарта начального общего образования, года подведения первых результатов. Представлена их связь с инновачиями в начальной школе. Обоснована актуальность вопросов сентября 2014 учебного года - начала четвертого года внедрения нового стандарта в начальном образовании. Они связанны с системой оценки достижения новых планируемых результатов в условиях реализаџии нового стандарта. Представлены их основные особенности. В первую очередь вопросы всех участников образовательного проиесса (учителей, родителей, руководителей школ и систем образования) связаны со спецификой измененных контрольно-измерительных материалов для контроля и оценки метапредметных результатов: познавательных, регулятивных, коммуникативных. Проанализирована динамика актуальных вопросов внедрения стандарта в разные периоды: разработки стандарта «второго поколения», знакомства педагогов со структурой и содержанием ФГОС, начала реализачии требований ФГОС, первого выпуска обучающихся в условиях реализачии требований ФГОС НОО. Все актуальные вопросы педагогов сгруппированы: о контроле и оценке достижения результатов, о методике обучения в реализации стандарта, об условиях, о первых результатах контроля качества образования, подготовки школ своих основных образовательных программ. Перечислены направления использования актуальных вопросов, связанных с внедрением стандарта для развития образования, планирования методической работы и поиска способов решения этих вопросов.
\end{abstract}

Ключевые слова: актуальность, федеральный государственный образовательный стандарт начального общего образования, инновации, методические инновачии, методическая работа.

Актуальные вопросы необходимо выявлять на каждом этапе развития для того, чтобы своевременно и адекватно реагировать, находить ответы на них. Психологи утверждают, что мышление «включается» в ответ на вопрос. Это вопросы, на которые в каче- стве самоконтроля должны ответить учителя и руководители образовательных учреждений. Как известно, актуальность - это важность, значительность чего-либо для настоящего момента.

Смолеусова Татьяна Викторовна - кандидат педагогических наук, профессор кафедры начального образования, Новосибирский институт повышения квалификации и переподготовки работников образования, Почетный работник общего образования РФ.

E-mail: smoleusova@mail.ru 
Настоящий момент российского образования характеризуется развитием в условиях новой системы ценностей глобального общества [5-6], социально-экономических изменений, внедрением федерального государственного образовательного стандарта на всех уровнях общего и профессионального образования ${ }^{1}$. Даже в дошкольном образовании появился ФГОС [8]. Для начального общего образования сентябрь 2014 года - особое время. Начался четвертый учебный год работы по ФГОС НОО - год подведения первых результатов внедрения федерального государственного образовательного стандарта в начальном общем образовании. Поэтому для всех учителей, работающих в четвертых классах, для организаторов и руководителей школ и систем образования самыми актуальными вопросами в этом году является следующие: «Как будут оценивать достижение планируемых результатов обучающихся первого выпуска по ФГОС НОО?», «Какие измерительные материалы будут использовать?», «Какие будут первые результаты первого выпуска достижения новых планируемых результатов?», «Как будут контролировать и оценивать достижение обучающимися метапредметных результатов: познавательных, регулятивных, коммуникативных?», «Будет ли контроль или мониторинг сформированности у обучающихся личностных результатов? Если да, то, как и кто это будет делать?»

Федеральные государственные образовательные стандарты выдвигают новые социальные требования не только к результатам реализации основной образовательной программы, но и к системе школьного обучения, к структуре и условиям реализации ООП. По-

\footnotetext{
${ }^{1}$ Федеральный государственный образовательный стандарт общего образования: текст с изм. и доп. на 2011 г., 2012 г. / М-во образования и науки РФ. - М.: Просвещение, 2014. - 33 с.
}

этому актуальные вопросы в современном образовании связаны с внедрением ФГОС от всех участников образовательного процесса: учителей с разным стажем, выпускников педагогических вузов и колледжей, вопросы на курсах повышения квалификации и в сети Интернет, выявленные в ходе анкетирования и мониторингов: «Какая школа наиболее готова к введению стандарта?», «Какие разделы ООП НОО менее разработаны?», «Учтены ли в ООП НОО школы изменения ФГОС $\mathrm{HOO}$ 2012 г.?», «Как провести современный урок?», «Как реализовать основной подход реализации ФГОС $\mathrm{HOO}$ - системнодеятельностный подход?», «Какие еще подходы заложены в ФГОС НОО?», «Какие инновационные технологии помогут реализовать ФГОС НОО на уроках?», «Как эффективно использовать все виды условий реализации ФГОС НОO?», «Какова динамика актуальных вопросов, связанных с внедрением за последние несколько лет?»

Стремительные изменения в обществе и экономике требуют от человека умения быстро адаптироваться к новым условиям, находить оптимальные решения сложных вопросов, проявляя гибкость и творчество, не теряться в ситуации неопределенности, уметь налаживать эффективные коммуникации с разными людьми и при этом оставаться нравственным. Задача современной школы - подготовить выпускника, обладающего необходимым набором современных знаний, умений и качеств, позволяющих ему уверенно чувствовать себя в самостоятельной жизни. Какой должна быть школа, чтобы выполнить задачу, поставленную перед ней государством? Какие вопросы, связанные с ФГОС задавались, обсуждались, решались в разные периоды?

Рассмотрим следующие периоды внедрения ФГОС: 
1. Период разработки стандарта «второго поколения».

2. Период знакомства педагогов со структурой и содержанием ФГОС.

3. Период начала реализации требований ФГОС.

4. Период - год первого выпуска обучающихся в условиях реализации требований ФГОС НОO.

ФГОС НОО из всех стандартов появился первым. Поэтому по его внедрению и реализации появились уже вопросы. В первые три периода внедрения ФГОС НОО актуальными были вопросы вида:

- Что такое федеральный государственный образовательный стандарт?

- В чём его отличие от прежнего стандарта и почему образование нуждается в подобных переменах?

- Что изменится в жизни школьников и их родителей в связи с введением нового стандарта?

- Предполагается ли, что с введением нового стандарта школы будут оснащены новым оборудованием?

На данном этапе внедрения ФГОС $\mathrm{HOO}$ имеются свои вопросы кроме системы оценки. Методологические публикации помогли школьным учителям и преподавателям системы повышения квалификации осознать необходимые изменения, дидактику, принципы и идеи. Трудно не согласиться с академиком В. С. Лазаревым, который утверждает, что достичь требуемых ФГОС результатов образования на основе сегодняшнего содержания образовательных программ и ассоциативно-репродуктивной технологии обучения невозможно. Таким образом, введение нового стандарта образования требует взаимосвязанных качественных изменений во всех компонентах образовательной системы школы, т. е. необходимость системной модернизации. Для успешного решения таких сложных задач опоры на опыт, здравый смысл и интуицию совершенно недостаточно, нужно применять специальные технологии инновационной деятельности [4]. Как убеждает анализ практики большого количества уроков, анкет учителей, их вопросов, специальные технологии инновационной деятельности необходимы на методическом уровне. Чаще других вопросов, учителя задают методические вопросы. «Как реализовать на уроке ФГОС?», «Как формировать УУД?», «Как решать основные задачи по каждому учебному предмету?», «Как реализовать разные востребованные новым стандартом инновационные подходы?», «Как использовать ИКТ для реализации требований ФГОС?»

Таким образом, изучение федерального государственного образовательного стандарта востребовано на разных уровнях: нормативно-правовом, дидактическом, методическом, прикладном. Автором данной статьи введено понятие «методические инновации», разработана концепция проектирования и развития методических инноваций в начальном математическом образовании, разработаны конкретные инновационные технологии, методические инновации для реализации требований ФГОС НОО в математическое образование, формировании УУД в начальном математическом образовании [7-8].

Разработка методических рекомендаций еще не поспевает за спросом на них. Необходимые изменения в образовании не могут происходить, если педагоги не будут стремиться совершенствовать свою профессиональную деятельность. Время и усилия, которые требуются, чтобы новые идеи и новые способы образования вошли в практику, в большой степени зависят от готовности и способности учителей, воспитателей изменять свою деятельность, осваивая новшества 
и становясь со-творцами новой практики [3]. Для учительского творчества стимулирующим фактором является участие в муниципальных, региональных и федеральных семинарах и конференциях, к которым они серьезно готовятся, консультируются с экспертами. Директора гимназий и лицеев для помощи учителям в подготовке инновационных уроков приглашают к сотрудничеству научных консультантов из числа авторитетных специалистов, преподавателей институтов повышения квалификации, авторов учебников и учебных пособий для современной начальной школы.

Наступил период контроля качества образования, разработанных основных образовательных программ. Появляются вопросы, связанные с мониторингом и контролем готовности школ к реализации ФГОС НОО:

1. Какая школа наиболее готова к введению стандарта?

2. Какие разделы ООП НОО менее разработаны?

3. Учтены ли в ООП НОО школы изменения ФГОС НОО 2012 г.?

Работа автора в качестве эксперта позволяет дать ответ на два из этих вопросов. В школьных ООП НОО наименее разработанными являются: программа формирования универсальных учебных действий; система оценки достижения обучающимися планируемых результатов. В разделе ООП НОО, связанном с кадровыми условиями не отражаются индивидуальные маршруты профессионального роста учителей школы (план повышения квалификации с указанием предпочитаемой темы, план выхода на аттестацию, план распространения своего профессионального опыта через планирование участия в конференциях, подготовки публикаций, организации семинаров на разных уровнях). Какие темы методической работы школы, само- образования и самоанализов учителей необходимо выбрать? Этот вопрос важно обсуждать на методическом объединении, с научным консультантом. Например, большое значение в ФГОС НОО его разработчиками уделено учету индивидуальных и возрастных особенностей обучающихся. Все ли учителя готовы к реализации этого требования? Как это отражено в ООП? Все актуальные вопросы педагогов можно сгруппировать и разделить. Вопросы о контроле и оценке достижения результатов, о методике обучения в реализации стандарта, об условиях, о первых результатах контроля качества образования, подготовки школ своих основных образовательных программ.

Таким образом, можно говорить о своеобразном списке из десяти актуальных вопросов внедрения ФГОС НОО на период сентябрь 2014 г.:

1. Как будут оценивать достижение планируемых результатов обучающихся первого выпуска по ФГОС НОО и как к этому готовиться?

2. Какая школа наиболее готова к введению стандарта?

3. Какие разделы ООП НОО образовательных учреждений менее разработаны? Учтены ли в ООП НОО школы изменения, внесенные в ФГОС НОО 2011г., 2012 г.?

4. Как реализовывать на уроке ФГОС HOO?

5. Как провести современный урок, соответствующий требованиям ФГОС НОО?

6. Как реализовать на уроках основной подход реализации ФГОС $\mathrm{HOO}$ - системно-деятельностный подход?

7. Какие еще подходы заложены в ФГОС НОO?

8. Какие инновационные технологии, методика помогут учителю формировать 
УУД и реализовать требования ФГОС НОО на уроках?

9. Как эффективно использовать все виды условий реализации ФГОС НОО?

10. Какие темы методической работы школы, самообразования и самоанализов учителей выбрать?

Указанные актуальные вопросы и поиск на них ответов могут и должны быть положены в основу планирования методической работы школы, района, города; планирования внутришкольного контроля; выбора тематики самоанализов учителей и направлений дальнейшего развития образования; повышения эффективности внедрения требований ФГОС HOO в массовую практику. Ответы на перечисленные и многие другие актуальные вопросы внедрения требований ФГОС $\mathrm{HOO}$ в практику урока активно ищут ученые и учителя-практики. Уже имеется многолетний опыт по реализации методических инноваций, индивидуализации, дифференцированному обучению в начальном математическом образовании [1, 9-12].

\section{СПИСОК ЛИТЕРАТУРЫ}

1. Истомина Н. Б., Заяц Ю. С. Практикум по методике обучения математике в начальной школе: Развивающее обучение. - Смоленск: Ассоциация XXI век, 2009. - 144 с.

2. Кларин М. В. Новая развивающая практика - коучинг. Новая профессия - коуч // Образовательные технологии. - 2014. - № 1. - С. 71-80.

3. Лазарев В. С. Формирование познавательных действий в учебной деятельности // Педагогика. - 2014. - № 6. - С. 3-12.

4. Лазарев В. С. Что нужно знать об инновационной деятельности учителя, чтобы она была успешной? // Инновации и эксперимент в образовании. http://www.in-exp.ru/component/ content/article/16-teor-in-exp-dejat/54-in-dejat-taecher.html (дата обращения: 3.07.2014)

5. Латуха О.А., Пушкарёв Ю.В. Роль высших учебных заведений в создании инноваций // Вестник Новосибирского государственного педагогического университета. - 2013. - № 3. C. 66-72.

6. Пушкарёв Ю. В., Пушкарёва Е. А. Развитие образования в условиях новой системы ценностей глобального общества // Вестник Новосибирского государственного педагогического университета. - 2012. - № 4. - С. 20-25.

7. Смолеусова Т. В. Состояние профессиональной готовности учителей начальной школы к внедрению инноваций // Вестник Новосибирского государственного педагогического университета. - 2012 - № 3. - С. 5-18.

8. Смолеусова Т. В. Время методических инноваций // Начальная школа. - 2014. - № 2.

9. Смолеусова Т. В. Проекты по математике как методическая инновация // Начальная школа - 2013. - № 8 .

10. Смолеусова Т. В., Кривцова Л. А. Новая роль учителя в организации проектной деятельности учащихся // Сибирский учитель. - 2010. - № 3. - С. 42-44.

11. Смолеусова Т. В., Петровская Е. А. ТРИЗ для инновационной начальной школы в условиях перехода на ФГОС // Эффективность модернизации образования: методология, опыт, перспективы: сб. мат. Всерос. науч.-практ. конф. - Т. 3. - Новосибирск: Изд-во НИПКиПРО, 2010. - 388 с. - С. 61-65.

12. Смолеусова Т. В., Мазунина Е. А. Инновационность раздельно-параллельного обучения класса хоккеистов // Сибирский учитель. - 2010. - № 5. - С. 5-14. 
DOI: $10.15293 / 2226-3365.1405 .05$

Smoleusova Tatiana Viktorovna, Candidate of Pedagogical Sciences, Professor of Department of Primary Education, Novosibirsk Institute of Training and Retraining of Educators, Novosibirsk, Russian Federation.

E-mail: smoleusova@mail.ru

\title{
TOPICAL ISSUES OF IMPLEMENTATION OF THE FSES
}

\begin{abstract}
The paper analyzes the current issues of the fourth year of implementation of the requirements of federal state educational standards elementary general education, summarizing the first year results. Represented their relationship with innovation in elementary school. The urgency of the issues of the school year in September 2014 - the beginning of the fourth year of the adoption of new standards in primary education. They are connected with the system to assess the achievement of planned results in the new conditions of the implementation of the new standard. Presented their basic features. The first issues of all participants in the educational process (teachers, parents, school administrators and education systems) are related to the specifics of the modified test materials for monitoring and evaluating the results of a meta: cognitive, regulatory, communication. The dynamics of topical issues of implementing the standard in different periods: development of the standard, "second generation", looking for teachers with the structure and content of the educational standards, beginning of implementation of the requirements of the educational standards, first issue studied in the conditions to implement the requirements educational standards.

All current issues of teachers grouped as follows: on monitoring and evaluation of achievement of the teaching methods in the implementation of the standard, the conditions, the first results of the quality control of education, training schools of their basic educational programs. Listed uses of topical issues related to the implementation of the standard for the development of education, planning and methodical work and find ways to address these issues.
\end{abstract}

\section{Keywords}

relevance, federal state educational standards elementary general education, innovation, methodological innovations, methodical work

\section{REFERENCES}

1. Istomin N. B., Zayats Y. S. Workshop on teaching math in elementary school: Developmental education. Smolensk, XXI century Association Publ., 2009, 144 p. (In Russian)

2. Clarin M. V. Developing new practice - coaching. A new profession - coach. Educational Technology. 2014, no. 1, pp. 71-80. (In Russian)

3. Lazarev V. S. Formation cognitive actions in training activities. Pedagogy. 2014, no. 6, pp. 312. (In Russian)

4. Lazarev V. S. What you need to know about the innovative work of the teacher to make it successful? Innovation and experimentation in education. (In Russian) http://www.in-exp.ru/ component/content/article/16-teor-in-exp-dejat/54-in-dejat-taecher.html (accessed: 3.07.2014)

5. Latuha O.A., PushkarevYu.V. Role of higher educational institutions in creation of innovations. Novosibirsk State Pedagogical University Bulletin, 2013, no. 3 (13), pp. 66-72. (In Russian) 
6. Pushkarev Y. V., Pushkareva E. A. Development of education in conditions of new system of values of the global society. Novosibirsk State Pedagogical University Bulletin. 2012, no. 4, pp. 20-25. Available at: http://vestnik.nspu.ru/article/210 (accessed: 3.07.2014) (In Russian)

7. Smoleusova T. V. State of professional readiness of primary school teachers to innovate. Novosibirsk State Pedagogical University Bulletin. 2012, no. 3, pp. 5-18. Available at: http://vestnik.nspu.ru/article/195 (accessed: 03.07.2014) (In Russian)

8. Smoleusova T. V. Time methodical innovation. Elementary School. 2014, no. 2. (In Russian)

9. Smoleusova T. V. Projects in mathematics as a methodical innovation. Elementary School. 2013, no. 8. (In Russian)

10. Smoleusova T. V., Krivtsova L. A. Novaya the teacher's role in the organization of project activities of students. Siberian teacher. 2010, no. 3, pp. 42-44. (In Russian)

11. Smoleusova T. V., Petrovskaya E. A. TRIZ for the innovative elementary school in the transition to the GEF. Efficiency modernization of education: methodology, experience, perspective. Vol. 3, Novosibirsk, Novosibirsk Institute of Training and Retraining of Educators Publ., 2010, 388 p., pp. 61-65. (In Russian)

12. Smoleusova T. V., Mazunina E. A. Innovation separately - Parallel-parallel-training class players. Siberian teacher. 2010, no. 5, pp. 5-14. (In Russian) 


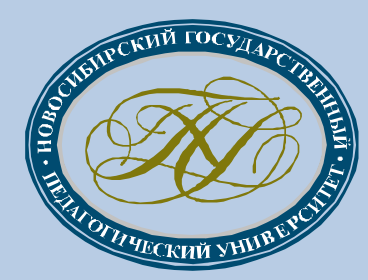

\section{www.vestnik.nspu.ru}

\section{ФИЛОСОФСКИЕ И ГУМАНИТАРНЫЕ НАУКИ}


Вестник Новосибирского государственного педагогического университета

5(21)2014 www.vestnik.nspu.ru ISSN 2226-3365

(C) В. Д. Павлова, Н. П. Чупахин

DOI: $10.15293 / 2226-3365.1405$

УДК 141.1

\title{
ОТ ФИЛОСОФИИ СМЫСЛА К ФИЛОСОФИИ КУЛЬТУРЫ
}

\author{
В. Д. Павлова, Н. П. Чупахин (Томск, Россия)
}

\begin{abstract}
Применяя алгоритм смыслообразования в области знания, находим четыре базисных уровня культуры - сочиальная, духовная, материальная и понятийная. Они объединяются смыслом взаимно однозначного соответствия потребностей и возможностей. С этой точки зрения, смысл философии культуры на схеме смыслообразования культур определяется пятым уровнем соответствия безграничных потребностей и возможностей. Он называется Vista перспектива, открыт В. Д. Павловой. Это понятие культуры является вершиной пирамиды культурного мира человечества, а исходящее из точки Vista ребра пирамиды определяют изменения направления времени внутреннего (логического) и внешнего (прошлого, настоящего и будущего), а грани пирамиды и плоскости основания пирамиды представляют информационные поля возможностей для объяснения и удовлетворения заданных потребностей.
\end{abstract}

Ключевые слова: философия, смысл и культура.

Философский дискурс смысла в конце II тысячелетия новой эры начался с великих открытий, сделанных в XIX и XX столетиях Г. Фреге, Р. Бартом, Л. Витгенштейном, Э. Гуссерлем, К. Юнгом, М. Хайдеггером, Г. Гадамером, Ж.-П. Сартром, Ж. Деррида, Ж. Делезом, Г. Шпетом, М. Бахтиным, А. Лосевым и другими философами. Они заложили основы и открыли такие разделы философии, как аналитическая философия, феноменология, герменевтика, экзистенциализм, постмодернизм. В каждом из разделов предметом изучения стал смысл.

\section{Смысл как соответствие}

Современное определение понятия смысла базируется на потребностях и возможностях самого объекта осмысления, а, именно: смысл - это взаимно однозначное соответствие между множествами потребностей и удовлетворяющих их возможностей [1, с. 63].

Процесс обретения смысла представляет собой актуализацию потенциальных возможностей потребностей, с помощью взаимно однозначно соответствующих им актуальных возможностей. Сущность смысла - в актуализации потенциала, т. е. в обретении новых актуальных возможностей.

Павлова Валентина Дмитриевна - соискатель, Томский государственный педагогический университет.

E-mail: chnp45@mail.ru

Чупахин Николай Петрович - доктор философских наук, профессор, Томский государственный педагогический университет.

E-mail: chnp45@mail.ru 
Образование смысла - четырехступенчатый процесс. Множество смыслов зависит от четырех параметров:

Первый параметр $\boldsymbol{A}$ (от англ. after после) - послеопределенность явления, феномена, имеющего потенциальные возможности удовлетворять потребности. Овладение потенциалом этого феномена становится целью-потребностью. С философской точки зрения послеопределенность характеризуется как мироосвоение.

Второй параметр $\boldsymbol{N}$ (от англ. nothing ничто) - неопределенность - это универ- сальное множество всех возможностей мира. $\boldsymbol{N}$ характеризуется как мировосприятие.

Третий параметр $\boldsymbol{B}$ (от англ. before - до) - предопределённость - множество гипотез абстрактного представления о явлении $\boldsymbol{A}$, характеризуется как миропонимание.

Четвертый $\boldsymbol{G}$ (от англ. general - общий) - всеопределенность - это бытие известных феноменов, с которыми сравнивается $\boldsymbol{A}$, характеризуется как мировоззрение.

Описание и характеристика шагов алгоритма смыслообразования описана в других работах авторов [1-4] (рис. 1).

Рисунок 1.

Интерпретация алгоритма смыслообразования

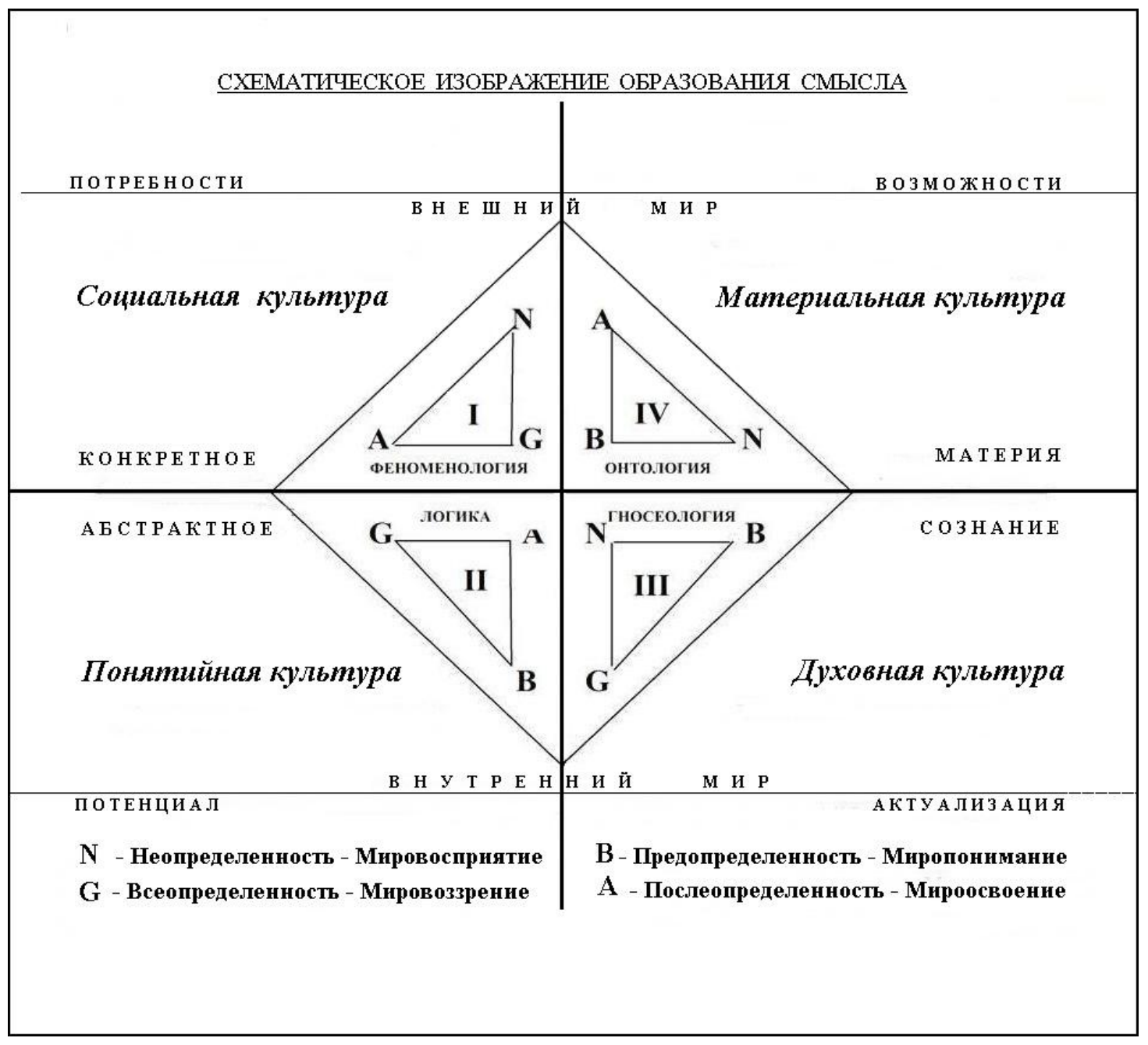


Вестник Новосибирского государственного педагогического университета

5(21)2014 www.vestnik.nspu.ru

ISSN 2226-3365

Верхняя часть области определения смысла соответствует внешнему миру по отношению к человеку, а нижняя - его внутреннему миру.

Первый шаг алгоритма смыслообразования (I) - в левой половине верхней части схемы, посвящен возникновению перед человеком явления послеопределенности $\boldsymbol{A}$ и изучается в феноменологическом разделе философии как проблема сочиальной культуры.

Социальная культура определяется с помощью функционального разделения общества по общественной значимости людей, материальной принадлежности и духовного осознания жизненной стратегии разума, веры, права и справедливости, искусства, эстетического чувств и этических норм.

Второй шаг алгоритма (II) в левой нижней части схемы - это понятийная культура, которая определяется логикой исследования явления $\boldsymbol{A}$.

Понятийная культура включает в себя дискурсивную логику структуры мышления человека для удовлетворения абстрактного и конкретного обозначения понятий, т. е. названий любого явления или предмета, выделяя его из общего ряда определений, в каждой из культурных областей человеческого мира.

Обе части левой половины схемы характеризуют понятие потребности, как потенциала явления $\boldsymbol{A}$. В правой части (III-IV) отображены возможности, актуализирующие потенциал тех же потребностей.

С философской точки зрения, понятие духовной культуры обосновано в гносеологии (III) (см. в нижней правой части рис. 1).

Духовная культура - это отображение внутреннего мира человека посредством материальных предметов и социальных явлений, включая религиозные верования; для удовлетворения его чувственных и психических потребностей и их воплощения через идейные и реальные возможности.

Материальная культура в ее онтологической интерпретации занимает верхнюю правую часть схемы смыслообразования (IV).

Материальная культура - воплощение в предметной сфере бытия идейного смысла сознания для удовлетворения духовных и социальных потребностей при помощи реальных возможностей.

Заметим, что верхняя половина области - социальная и материальная культура относится к множеству конкретного в материи. Нижняя половина - понятийная и духовная культура - является абстракцией сознания.

\section{Смысл философии культуры}

Исторически наибольшие изменения испытывает идеологическая составляющая культурных течений. Легче и проще всего изменить идею или мысль, если таковая возникает, т. к. она не требует материальных средств и временных затрат. Вместе с тем, именно материальная культура, существуя продолжительное время во внешнем мире, для изменения требует больших средств и времени, и поэтому изменяется не так быстро в сравнении с другими культурными течениями. Но, заметим, что для трансформации элементов и социальной, и материальной, и духовной культуры необходимо возникновение новых понятий или изменение определений и смысла уже используемых понятий во всех этих культурах [5-9].

Таким образом, смеем утверждать, что понятийная культура является 
неотъемлемой и вместе с тем необходимой и значимой частью всех названных культур данной схемы смыслообразования.

«Культурфилософия», как назвали её в самом начале образования понятия культуры, возникла вместе с определением понятия человека как биологического вида, наделенного сознанием и абстрактным мышлением. К этому моменту многообразие явлений - интегрированная культурная система (собрание или комплекс языков, наук, религий, искусства, этики и права) существовал в виде носителей смысла в период двадцати тысячелетий, претерпевая различные мировоззренческие подходы, соответствующие периодам создания культуры современным рефлексивным человеком на Западе, Востоке, Индии и Китае. Философские воззрения легли в основу культурного мира, созданного универсальным рациональным мышлением. Впервые перед человеком открылась проблема ответствен-ности за своё существование в глобальном пространстве его разума.

Если мы вернемся к схеме смыслообразования, то увидим, что на первом шаге основным параметром смысла в культуре является неопределенность (N) (рис. 1). В такой неопределенности человек обращается к мировоззрению, доступному тезаурусу своих знаний на уровне мистикототемического менталитета вместо естественных причин наследственных связей, приспосабливая душевный опыт веры к объяснению всех явлений. Система мифов мистическим мышлением компенсировала недостаток представлений в силу отсутствия логики. Позднее эмпирический опыт способствовал возникновению понятий и логических операций, позволяющих отрицать мифические представления. Так, на втором эmane алгоритма смыслообразования мы видим, что предопределенность (B) миропонимания, наращивание понятийных, не мифологических элементов, ведет к появлению логики. Всеопределенность (G), рассматриваемая как теоретические размышления на третьем шаге схемы смыслообразования, в эмпирическом миропонимании находит ментальное основание для духовной культуры в виде культурного мира личности.

И, наконец, культурные формы совместной деятельности людей, направленные на жизнеобеспечение, обогащенные идеями логики и теоретического исследования рождают хозяйственно-экономическую, политическую, социальную и правовую культуру. Они стали основными в современной цивилизации информационными носителями смысла, такими, как СМИ, литература, сетевая культура, компьютерная графика, гипер-тексты, сеть Интернет и т. д. Четвертый этап - послеопределенность (А) мироосвоения - это носители информации о смысле, созданные посредством доступных современных достижений техники - а именно, всеобщей коммуникации и компьютеризации всех социальных слоев населения в цивилизованном мире.

Такова, в общих чертах, картина смыслообразования в культуре с точки зрения философии смысла знания.

Вершиной схемы смыслообразования философии культуры следует назвать новый, открытый В. Д. Павловой, пятый уровень культуру потребностей и возможностей. Культура потребностей и возможностей определяется для всего существующего как объективно реального, так и субъективноличностного мира людей, животных и самой природы. Одним из феноменологических примеров субъектов понятийной культуры в 
современном мире являются люди, условно называемые - индиго, иные, экстрасенсы и т.п.

Только на основании исторического развития социального, духовного, материального и понятийного аспектов культурного мира человечества возник новый параметр смыслового соответствия безграничных потребностей и возможностей ( $\boldsymbol{V}$ - от англ. vista - перспектива), как интегрированный переход от общего к частному. Эта культура как обобщенный образ культурного мира существовала на протяжении всех исторических этапов цивилизации, но именно в XXI в. она проявила себя как реально существующая данность для отображения и использования безграничных потребностей и возможностей. Осознание и желание личности использовать эти невероятные возможности для осуществления насущных потребностей развивают способности человеческого разума определять смысл существования цивилизации в целом. Таким образом, вершиной пирамиды культурного мира человечества $(\boldsymbol{V})$, определяющей в схеме смыслообразования перспективу Vista, мы назовем новую культуру потребностей $u$ возможностей.

Схематическое расположение Vista относительно других культур можно рассмотреть на рис. 2. Точка Vista на схеме может перемещаться в любую точку пространства и при этом не изменяет своих функций относительно других культур. Значок $\circlearrowleft$ обозначает на схеме эффект перемещения, наложения и проникновения культур во время их пространственного, а также временного вращения в их развитии.

При взаимодействии культур друг с другом, изменения в одной из них влекут за собой изменения в другой. Плоскости, ограничивающие грани пирамиды смысла философии культуры, являются носителями информационных полей таких возможностей, которые уже могут не только назвать, но и объяснить и удовлетворить заданные потребности.

В схематическом изображении культурных плоскостей на рисунке можно проследить соотношения и зависимости в их взаимодействии, если последовательно или в любом порядке условно накладывать одну плоскость культуры на другую или исключать из рассмотрения одну из культур. Интересно проследить развитие этих отношений или их невозможность существования друг без друга.

Следует понимать, что точек Vista существует бесконечное множество (на схеме изображена только одна точка $V$ для простоты чтения). Ребра перспективы Vista, являясь направлениями времени, обозначают: VA -внешнее прошлое; VB внутреннее (логическое) время; VG (реальное) настоящее и $\boldsymbol{V N}-$ (возможное) будущее. Они пересекаются с основанием и определяют информационные поля граней развития и изменения как выше указанных, так и других культур, обозначаемых через $\boldsymbol{V}$ с индексом.

Социальная культура определяет личностные отношения. Понятийная культура призвана определить виртуальное существование явлений феномена. Духовная культура это знания, доказанные опытом или принятые на веру. Материальная культура является реальным воплощением (носителем) духовных ценностей. А именно, культура потребностей и возможностей есть основа существования всех названных культур, которую можно определить, назвать, логически объяснить и изменить при их взаимодействии друг с другом [10-12]. Каждая из этих культур (социальная, понятийная, духовная, мате- 
риальная), может функционально существовать только, если выполняется факт присутствия культуры потребностей и возможностей.

Рисунок 2.

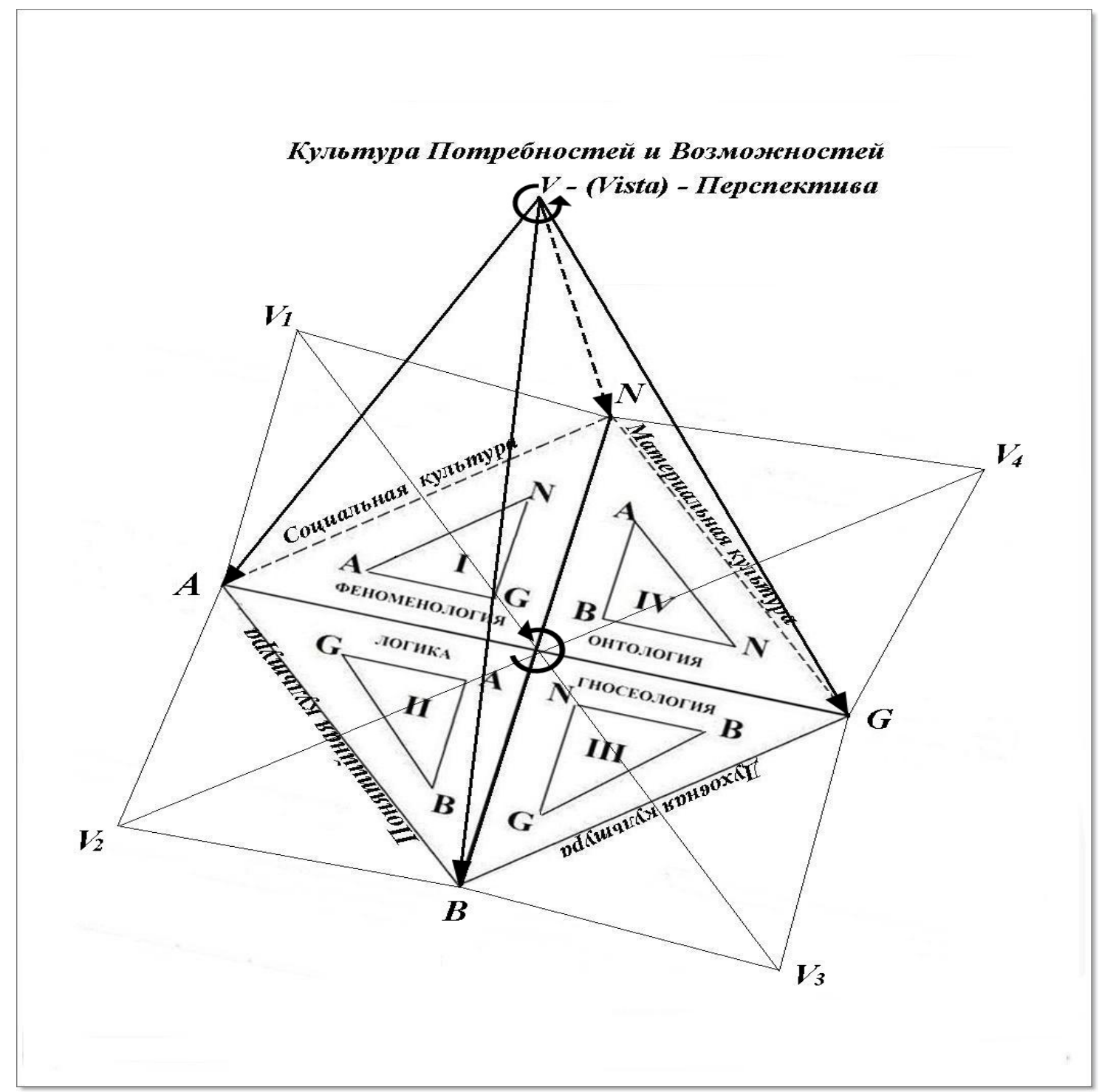

\section{СПИСОК ЛИТЕРАТУРЫ}

1. Чупахин Н. П. Философские основания и математическая модель смысла знания: монография. - Saarbrücken: LAP LAMBERT Academic Publishing, Germany, 2011. - 341 c.

2. Чупахин Н. П. Введение в философию и математику смысла. - Томск: Изд-во ТГПУ, 2004. $-172 \mathrm{c}$. 


5(21)2014 www.vestnik.nspu.ru ISSN 2226-3365

3. Чупахин Н. П. Математика и философия смысла культурного мира. - Томск: Изд-во ТГПУ, 2004. - $156 \mathrm{c}$.

4. Чупахин Н.П. Семантический треугольник Готлоба Фреге и семантический тетраэдр в философии смысла // Вестник Новосибирского государственного педагогического университета - 2012. - № 1 (5). - С. 59-67

5. Заречнева Н.Г., Чупахин Н.П. Структура теоретического знания и языковая коммуникация // Вестник Новосибирского государственного педагогического университета. - 2012. № 6. - C. 32-36.

6. Лелюшкина К.С., Чупахин Н.П. Понимание субъективно личностного смысла как предпосылка обучения иноязычному общению // Известия Томского политехнического университета. - 2011. - № 6. - С. 146-151.

7. Чупахин Н.П. Расслоенное пространство возможностей как модель смысловой структуры теоретического знания // Вестник Алтайской науки. - 2009. - № 4 (7) - С. 125-130.

8. Чупахин Н.П. Культура научного поиска. - М.: НИА «Наследие Отечества», 2010. - 24 с.

9. Чупахин Н.П. Потенциал и актуализация знания как основания культуры научного поиска // Вестник Томского государственного педагогического университета. - 2012. - № 4 -c. $226-228$.

10. Пушкарев Ю. В., Пушкарева Е. А. Информатизация как средство интеграции науки и образования // Философия образования. - 2008. - № 2. - С. 201-207.

11. Пушкарева Е. А. Знание как основа науки и образования: специфика современного состояния // Философия образования. - 2007. - № 3. - С. 31-35.

12. Пушкарёва Е. А. Философское мышление для формирования рефлексивности познания в образовательном процессе // Вестник Новосибирского государственного педагогического университета - 2012. - № 1 (5). - С. 74-78 
DOI: $10.15293 / 2226-3365.1405$

Pavlova Valentina Dmitrievna, Post Graduate, Tomsk State Pedagogical University, Tomsk, Russian Federation.

E-mail: chnp45@mail.ru

Chupahin Nikolai Petrovich, Doctor of Philosophical Sciences, Professor, Tomsk State Pedagogical University, Tomsk, Russian Federation.

E-mail: chnp45@mail.ru

\section{PHILOSOPHY OF MEANING TO PHILOSOPHY OF CULTURE}

\section{Abstract}

Applying the algorithm of meaning in the knowledge there are four basic levels of culture - social, spiritual, material and conceptual. They unite meaning one correspondence needs and opportunities. From this perspective, the meaning of the philosophy of culture in the scheme of meaning defined cultures fifth level of compliance unlimited needs and opportunities, called Vista, open V. D. Pavlova. This concept of culture is the pinnacle of the pyramid of the cultural world of mankind, and emanating from the edges of the pyramid point Vista detect changes time direction internal (logical) and external (past, present and future), and the faces of the pyramid and the plane of the base of the pyramid represent the information field of possibilities to explain and to meet specified needs.

\section{Keywords}

philosophy, meaning and culture

\section{REFERENCES}

1. Chupakhin N. P. Philosophical base and mathematical model of the meaning of knowledge. Monograph. Saarbrücken, LAP LAMBERT Academic Publ., Germany, 2011. (In Russian)

2. Chupakhin N. P. Introduction to philosophy and mathematics sense. Tomsk, Tomsk State Pedagogical University Publ., 2004. (In Russian)

3. Chupakhin N. P. Mathematics and philosophy of the world cultural sense. Tomsk, Tomsk State Pedagogical University Publ., 2004. (In Russian)

4. Chukpahin N. P. Semantic triangle by Gotlob Frege and semantic tetrahedron in philosophy of sense. Novosibirsk State Pedagogical University Bulletin, 2012, no. 1, pp. 59-67. (In Russian)

5. Zarechneva N.G., Chupakhin N.P. The structure of theoretical knowledge and language communication. Novosibirsk State Pedagogical University Bulletin, 2012, no. 6, pp. 32-36. (In Russian)

6. Lelushkina K.S., Chupakhin N.P. Comprehension of "Subject-Personal" Sense as a Prerequisite for Foreign Communication Teaching. Tomsk Polytechnic University Bulletin, 2011. no. 6, pp. 146151. (In Russian)

7. Chupakhin N.P. Foliated space of possibility as a model of meaning structure for a priori knowledge. Bulletin of Altai scientific, 2009. no. 4, pp. 125-130. (In Russian)

8. Chupakhin N.P. Culture of scientific search. Moscow: NIA Legacy of fatherland Publ., 2010, 24 p. (In Russian).

9. Chupakhin N. P. Potential and actualization of knowledge as basement of scientific search. Tomsk State Pedagogical University Bulletin, 2012, no. 4, pp. 226-228. (In Russian) 
10. Pushkarev Yu. V., Pushkareva E. A. Features of modern development of a science in high school: the theoretical-methodological analysis. Novosibirsk State Pedagogical University Bulletin, 2012, no. 5 (9), pp. 28-36. (In Russian)

11. Pushkareva E.A. Knowledge as a basis of a science and education: specificity of a modern condition. Philosophy of education, 2007, no. 3 (20), pp. 31-35. (In Russian)

12. Pushkareva E.A. Philosophical thinking for formation of reflexivity of knowledge of educational process. Novosibirsk State Pedagogical University Bulletin, 2012, no. 1, pp. 74-78. (In Russian) 


\title{
ИНЖЕНЕРНО-ТЕХНИЧЕСКАЯ ИНТЕЛЛИГЕНЦИЯ ТЮМЕНСКОЙ ОБЛАСТИ В СОВРЕМЕННОМ ИСТОРИОГРАФИЧЕСКОМ АНАЛИЗЕ
}

\author{
3. Р. Жукочкая, О. А. Фаненштыль (Нижневартовск, Россия)
}

В статье предложен совокупный историографический анализ современных исследовательских работ, посвященных истории советской инженерно-технической интеллигенции Тюменской области, который выделяет круг ключевых проблем, свойственных современному интеллигентоведению. Особое внимание автор обращает на региональный аспект проблемы.

Во-первых, это проблемы определения обобщающих критериев, закладывающих основы научной дефиниции, вызванные, с одной стороны, всплеском интереса к изучению основ этой сочиально-профессиональной группы и многообразием взглядов исследователей постсоветского периода, а с другой, неизбежно возникающей противоречивостью эмпирического и культурологического направлений исследований, где усиление морально-нравственных, этических позиций меняет сущңность социологических определений и довлеет над иченностно-нейтральными, сознательно избегающими моральных устоев.

Во-вторых, проблемы поиска новых научно-методологических подходов изучения истории интеллигенции и ее инженерно-технической социально-профессиональной группы. Среди приоритетных в статье выделяются конщепщии С. А. Красильникова, В. Ш. Назимовой, А. В. Квакина. Различные по своей направленности теории представленных авторов позволяют абстрагироваться как от сочио-исторического, так и философско-культурологического подходов, придержсиваясь более широких, междисииплинарных, синергетических принципов.

В третьих, проблемы, связанные с механизмами исследований истории интеллигенции регионов, и в частности инженерно-технической интеллигенции Тюменской области.

Ключевые слова: историографический анализ, комплексные исследования, инженернотехническая интеллигенция, региональный аспект.

Жукоцкая Зинаида Романовна - доктор культурологии, профессор кафедры культурологии и философии, Нижневартовский экономико-правовой институт (филиал), Тюменский государственный университет.

E-mail: vlad@nv-study.ru

Фаненштыль Ольга Александровна - кандидат исторических наук, доцент кафедры культурологии и философии, Нижневартовский экономико-правовой институт (филиал), Тюменский государственный университет.

E-mail: fanenshtyl_olga@mail.ru 
За последние десятилетия произошли существенные изменения в характере исследовательских работ по истории интеллигенции, в том числе и инженерно-технической группы. Исследования советской эпохи, учитывая их партийно-государственную риторику, сознательно замалчивались или отвергались, в то же время появились работы, характерные для постсоветского периода. Многообразие взглядов, возникших в постсоветский период, породило дискуссионные обсуждения проблемы. Прежде всего, они коснулись самого понятия «интеллигенция», обобщающих критериев, закладывающих основы научной дефиниции. Усилился приоритет морально-нравственных, этических подходов к определению, где основополагающим являлся постулат Д. С. Лихачева: «Интеллигенты - это не просто люди, занятые умственным трудом, имеющие знания или даже просто высшее образование, а воспитанные на основе своих знаний классической литературы, исполненные духа терпимости к чужим ценностям, уважения к другим» [1, c. 252].

В то же время ценностно-нейтральные, социологические определения интеллигенции, отодвинулись на второй план, хотя именно они определяют критерии для сопоставления эмпирических характеристик интеллигенции, сознательно опуская моральноэтический подход, который не инструментален для конкретно-исторических исследований, тем более, если исследования касаются отдельных групп интеллигенции.

По мнению В. Р. Веселова в любом практическом (эмпирическом) исследовании в качестве объекта изначально будут фигурировать инженеры, врачи, учителя, т. е. конкретные социально-профессиональные группы. При этом характеристика нравственноэтических качеств интеллигенции будет осу- ществляться органично: не запрограммированная заранее идеальная схема вечных добродетелей, а противоречивый облик земных людей в единстве их духовных взлетов и грехопадений [2, с. 7].

А. Н. Севастьянов в монографии «Диктатура интеллигенции против утопии среднего класса» заключает: «Интеллигенция может делиться на нравственную и безнравственную, творческую и косную, блистательную и серую: но самый высоконравственный человек, не имеющий образования и не занятый умственным трудом не интеллигент» [3, c. 16].

Решая проблему противопоставления понятий интеллигенция и интеллектуалы, В. С. Меметов видит больше сближающих, чем разъединяющих начал. Так, в процессе развития любая социальная группа создает собственную интеллигенцию, представляющую из себя интеллектуальный слой данной группы [4, с. 65]. В этой связи интеллектуал является составной частью интеллигенции или оба эти понятия, по мнению А. В. Квакина, тождественны [5, с. 168].

Своеобразным итогом полемики можно считать позицию В. Г. Ледяева. Он выводит одну из ключевых аналитических проблем современной историографии: «Чем больше параметров и критериев включается в определение интеллигенции, тем меньше у него шансов быть принятым научной общественностью» [6, с. 14].

Другим направлением развития современной историографии советской инженернотехнической интеллигенции стал поиск новых научно-методологических подходов изучения истории этой социальнопрофессиональной группы. Так, С. А. Красильников рассматривает интеллигенцию через вводимое понятие интеллектуального потенциала общества. По мнению В. Ш. Нази- 
мовой, проблема места и роли интеллигенции внутри отдельных регионов может раскрываться на основе историко-статистической модели, «отраслевой», соединенной с «деятельностной» и социокультурной (междисциплинарной) [7, с. 31].

Продолжая идею, А. В. Квакин указывает на узость постановки задач изучения истории интеллигенции, как сторонниками социо-исторического, так и философскокультурологического подходов, исключающую возможность видеть интеллигенцию не только как предмет, но и как объект. Можно констатировать, заключает А. В. Квакин, что интеллигенцию как объект еще предстоит исследовать [8, с. 32]. Одним из наиболее продуктивных современных подходов в изучении истории интеллигенции он называет синергетику и рассмотрение данного социального явления через хаос. Синергетика позволяет с современной точки зрения рассмотреть природу генезиса и эволюции такого сложного явления общественно-социальной жизни, как интеллигенция. Сложность может заключаться в объективности самого исследователя интеллигенции, т. к., пытаясь созерцать свой объект исследования со стороны, он не перестает быть его частью [9, с. 33].

В действительности, только комплексный анализ исследований, посвященных инженерно-технической интеллигенции России может дать объективную картину подходов к анализу развития этой социальнопрофессиональной группы.

Опираясь на концептуальные исследования и подходы, большая часть современных исследователей истории инженернотехнической интеллигенции, тем не менее, идя опытным путем, сосредоточилась на изучении облика советского инженера, его профессиональной и бытовой повседневности, творческого и культурного потенциала, его взаимоотношениями с властью, роли в формировании «инженера советского типа».

На рубеже 1980-1990-х гг. в работах историков нарастает тенденция к критической оценке деятельности КПСС по руководству инженерно-технической интеллигенцией. В поздних работах А. К. Булкина, В. С. Волкова, М. Е. Главацкого, прослеживается критический взгляд на деятельность партийных органов. Так, А. К. Булкин, обобщив большой фактический материал, пришел к заключению о несоответствии общего стиля работы партийных органов требованиям времени. При всем положительном значении партийного влияния на техническую интеллигенцию уже к концу 1970-х гг. становились все более типичными бюрократический подход, директивные методы руководства. Проблему преемственности и новаций в функциях и облике технической интеллигенции России различных исторических эпох раскрывает в своих публикациях В. С. Волков. Автор подчеркивает: «Роднили разные поколения российских инженеров патриотизм, сознание значимости своего труда, верность профессиональному долгу» [10, с. 52].

В работах А. К. Калинина, И. В. Бутенко привлекает отсутствие идеологических штампов, объективная оценка партийногосударственной политики по формированию и организации советского инженерного корпуса. Аналогичных подходов к проблеме формирования интеллигенции в рамках развития региона придерживаются в работах В. С. Терехова, Л. И. Лактионова, А. Н. Радиченко [11-13]. Попытку раскрыть производственную повседневность инженерного корпуса содержит исследование Т. Г. Чебоксаровой [14]. Анализируя материальное положение и организацию труда инженернотехнического персонала на промышленных предприятиях Западной Сибири в период но- 
вой экономической политики, автор приходит к выводу, что отсутствие свободного времени на отдых приводило к хронической усталости специалистов, к падению их сил и здоровья, а также сказывалось на образовательном и профессиональном уровне.

С созданием крупнейшего в стране Западно-Сибирского нефтегазового комплекса историки стали проявлять интерес к проблемам формирования инженерно-технической интеллигенции в Тюменском регионе.

Существенный вклад в исследование социальной структуры населения Тюменской области 1960-1980-х гг. (в том числе инженерно-технической интеллигенции) внесли Л. В. Алексеева, Н. Ю. Гаврилова, В. П. Карпов, Д. И. Карякин, Г. Ю. Колева, Н. М. Пашков и другие ученые, чьи работы были посвящены проблеме освоения природных ресурсов Западной Сибири или отдельным аспектам данного процесса. Исследовательский интерес представляет вывод Н. Ю. Гавриловой и В. П. Карпова о возможной реализации комплексного подхода в освоении нефтегазовых богатств региона, одним из важных компонентов которого считалось создание благоприятных жизненных условий для тружеников края, в особенности квалифицированных специалистов. Они же одними из первых в регионе высказались критически о некоторых методах «партийно-советского руководства» в освоении нефтегазовых богатств на севере Тюменской области.

К истории формирования инженернотехнической интеллигенции в аграрном секторе экономики Тюменской области в 19601980-е гг. обратилась О. В. Афонасьева, внимание которой привлекли количественные и качественные изменения в составе данной социальной группы, еe жилищно-бытовые условия и некоторые другие вопросы. Кадровые проблемы подсобных аграрных хозяйств промышленных предприятий и организаций края в начале 1980-х гг. изучал В. П. Лисин.

Анализируя роль инженерно-технической интеллигенции в развитии промышленности Зауралья в 1950-1960-х гг., О. Н. Гончаренко затрагивает проблему реализации творческого потенциала инженеров и техников Тюменских предприятий через научно-технические общества. «Изобретатели и рационализаторы сделали значительный вклад в комплексную механизацию и автоматизацию цехов, участков и линий, в освоении новых машин, приборов и аппаратов», заключает автор [15, с. 198-201].

Изменениям в структуре населения Сибири (в том числе и Тюменской области) посвящены работы Е. Д. Малинина, К. Н. Мисевича, А. К. Ушакова, В. И. Чудиновой, которые еще в 1970-е гг. показали, что на первых этапах создания Западно-Сибирского нефтегазового комплекса главную роль в формировании кадров нефтяной и газовой промышленности играли трудовые ресурсы из старых нефтегазопромысловых районов Поволжья и Северного Кавказа. На примере объединения «Главсибтрубопроводстрой» пути решения кадровых проблем в нефтегазовом строительстве Сибири проанализировали В. В. Алексеев, Е. В. Логунов и П. П. Шабанов.

Определенное место в историографии проблемы занимают труды, посвященные различным аспектам подготовки специалистов с высшим образованием, которые после завершения процесса обучения в вузах становились важным источником пополнения инженерно-технической интеллигенции Тюменской области. В 1980-е гг. к этим вопросам обращались Ю. М. Каськов, М. М. Савицкий, А. И. Трусь, С. Г. Щеглов.

Совокупность исследований рубежа XX-XXI вв., посвященных развитию советской интеллигенции, в том числе инженерно- 
технической группы, показывает преемственность исследовательских позиций авторов позднего советского и постсоветского периодов. Несмотря на критический анализ, облик советского инженера в сознании исследова- телей, по-прежнему неразрывно связан с промышленным подъемом, осознанием значимости своего труда, верностью профессиональному долгу.

\section{СПИСОК ЛИТЕРАТУРЫ}

1. Лихачев Д. С. Я вспоминаю. - М., 1991. - 256 с.

2. Веселов В. Р. Интеллигенция на рубеже эпох: проблемы исторического выбора и преемственности // Интеллигенция и мир. - 2001. - № 1. - С. 7.

3. Севастьянов А. Н. Диктатура интеллигенции против утопии среднего класса. - М., 2009. 192 c.

4. Сверчкова Л. П. Субъект духовного производства: методологический анализ. - Л., 1988. $127 \mathrm{c}$.

5. Квакин А. В. Интеллектуальная элита - интеллектуалы/интеллигенция: еще раз о соотнесении понятий // Интеллигенция и мир. - 2001. - № 2-3. - С. 168.

6. Ледяев В. Г. Понятие интеллигенции: проблемы концептуализации // Интеллигенция и мир. - 2001.- № 1. - С. 14.

7. Ледяев В. Г. Понятие интеллигенции: проблемы концептуализации // Интеллигенция и мир. - 2001.- № 1. - С. 31.

8. Квакин А. В. Интеллигенция России и выбор путей общественного развития // Интеллигенция России и Запада в XX-XXI вв.: поиск, выбор и реализация путей общественного развития. Материалы научной конференции 28-29 мая 2004 года. - Екатеринбург, 2004. C. 32 .

9. Квакин А. В. Интеллигенция России и выбор путей общественного развития // Интеллигенция России и Запада в XX-XXI вв.: поиск, выбор и реализация путей общественного развития. Материалы научной конференции 28-29 мая 2004 года. - Екатеринбург, 2004. C. 33 .

10. Волков В. С. Техническая интеллигенция России: традиции и новации в функциях и облике // Интеллигенция и мир. - 2001. - №. 1. - С. 52.

11. Терехов В. С. Инженерно-техническая интеллигенция Урала в 1930-е годы: автореф. дис. ... канд. истор. наук. - Екатеринбург. 1998.

12. Рачковский Ю. А. Роль интеллигенции в укреплении научно-технического потенциала СССР в годы Великой Отечественной войны: (На материалах государственных и партийных организаций): автореф. дис. ... канд. истор. наук. - СПб, 1995.

13. Лактионов В. В. Техническая интеллигенция в 1970-1980-х годах: (На материалах Центрального Черноземья): автореф. дис. ... канд. истор. наук. - Воронеж, 1995.

14. Чебоксарова Т. Г. Производственная повседневность технической интеллигенции в годы НЭПа: автореф. дис. ... канд. истор. наук. - Омск, 2007.

15. Гончаренко О. П. Роль интеллигенции в развитии НТО в Зауралье в 50-60-е гг. XX в. // Культура и интеллигенция России. Личности. Творчество. Интеллектуальные диалоги в эпоху политических модернизаций. Материалы VIII Всероссийской научной конференции с международным участием. - Омск. - 2012. - С. 198-201. 
DOI: $10.15293 / 2226-3365.1405 .07$

Zhukotskaya Zinaida, Doctor of Cultural Sciences, Professor of Cultural Sciences and Philosophy, Nizhnevartovsk Economics and Law Institute (branch) of Tyumen State University, Niznevartovsk, Russian Federation.

E-mail: vlad@nv-study.ru

Fanenshtyl Olga, Candidate of Historical Sciences, Associate Professor of Cultural Sciences and Philosophy, Nizhnevartovsk Economics and Law Institute (branch) of Tyumen State University, Niznevartovsk, Russian Federation.

E-mail: fanenshtyl_olga@mail.ru

\title{
ENGINEERING AND TECHNICAL INTELLIGENTSIA OF THE TYUMEN REGION IN MODERN HISTORIOGRAPHICAL ANALYSIS
}

\begin{abstract}
This paper investigates the problems of complex approach to modern historiographical analysis of the history of Soviet engineering and technical intelligentsia. The regional aspects of the problem are being of special attention. Firstly, these are the problematic issues to define the generalizing criteria which make the basis of the scientific definition. On the one hand, these issues are caused by the splash of interest to studying the fundamentals of this social professional group and by the various points of view of the researchers of the post soviet period. On the other hand, the issues mentioned above are closely connected with the appearing discrepancy of empiric and cultural research, when the increasing moral and ethical attitudes are changing the basics of sociological definitions and prevailing over the value neutral ones, which conscientiously avoid moral principles.

Secondly, there is the challenge to search new scientific and methodological approaches to study the history of intelligentsia and its engineering and technical professional group. The concepts by S. A. Krasilnikov, V. Sh. Nazimova, A. V. Kvakin are valued the most. They are original and help to distract from both social historical and philosophical cultural approaches. These concepts are based more on interdisciplinary synergetic principles.

Thirdly, there are the problems connected with the methods of studying the history of regional intelligentsia, in particular, engineering and technical intelligentsia of Tyumen region.

\section{Keywords}

historiographical analysis, complex approach, engineering and technical intelligentsia, case studies, historical and philosophical analysis, regional studies
\end{abstract}

\section{REFERENCES}

1. Likhachev D. S. Ya vspominayu [I remember]. Moscow, 1991, 265 p. (In Russian)

2. Veselov V. R. Intelligentsia at the turn of epochs: the problem of historical choice and continuity. Intelligentsia i mir [Intelligentsia and the world]. 2001, no. 1, p. 7. (In Russian)

3. Sevastianov A. N. The dictatorship of the intelligentsia against the utopia of the middle class. Moscow, 2009, 192 p. (In Russian) 
4. Sverchkova L. P. The subject of intellectual production: methodological analysis. Leningrad, 1988, 127 p. (In Russian)

5. Kvakin A. V. Intellectual elite - the intellectuals / intelligentsia: once again on the concepts. Intelligentsia i mir [Intelligentsia and the world]. 2001, no. 2-3, 168 p. (In Russian)

6. Ledyaev V. G. The concept of the intelligentsia: problems of conceptualization. Intelligentsia $i$ mir [Intelligentsia and the world]. 2001, no. 1, p. 14. (In Russian)

7. Ledyaev V. G. The concept of the intelligentsia: problems of conceptualization. Intelligentsia $i$ mir [Intelligentsia and the world]. 2001, no. 1, p. 31. (In Russian)

8. Kvakin A. V. Russian intelligentsia and the choice of ways of social development. Intelligentsia in Russia and the West in the XX-XXI centuries: search, select and implementation of ways of social development. Proceedings of the Conference on 28-29 May 2004. Yekaterinburg, 2004, p. 32. (In Russian)

9. Kvakin A. V. Russian intelligentsia and the choice of ways of social development. Intelligentsia in Russia and the West in the XX-XXI centuries: search, select and implementation of ways of social development. Proceedings of the Conference on 28-29 May 2004. Yekaterinburg, 2004, p. 33. (In Russian)

10. Volkov V. S. Technical intelligentsia in Russia: traditions and innovations in features and appearance. Intelligentsia i mir [Intelligentsia and the world]. 2001, no. 1, p. 52. (In Russian)

11. Terekhov V. S. Engineering and technical intelligentsia of the Urals in the 1930s. Yekaterinburg, 1998. (In Russian)

12. Raczkowski Y. A. Strengthening the role of intellectuals in the scientific and technical potential of the USSR in World War II (On materials of state and party organizations). Saint Petersburg, 1995. (In Russian)

13. Laktionov V. V. Technical intelligentsia in 1970-1980's (On materials of the Central Chernozem). Voronezh, 1995. (In Russian)

14. Cheboksarova T. G. Daily production and technical intelligentsia in the years of the NEP. Omsk, 2007. (In Russian)

15. Goncharenko O. P. The role of intellectuals in the development of STS in the Urals in 50-60 years of XX century. Culture and Russian intelligentsia. Personalities. Creativity. Intellectual dialogues in an era of political modernization. Proceedings of the VIII All-Russian scientific conference with international participation. Omsk, 2012, pp. 198-201. (In Russian) 


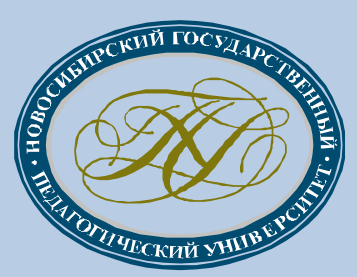

\section{www.vestnik.nspu.ru}

\section{НАУКИ О ЗЕМЛЕ}

\section{ФИЗИКО-МАТЕМАТИЧЕСКИЕ И ТЕХНИЧЕСКИЕ НАУКИ}


УДК $556.551+550.4$

\title{
ЭКОЛОГИЧЕСКОЕ СОСТОЯНИЕ ЛИМНОСИСТЕМ СЕВЕРО-ЗАПАДА БАРАБИНСКОЙ НИЗМЕННОСТИ
}

\author{
В. А. Бакаев (Новосибирск, Россия)
}

\begin{abstract}
Для диагностики современного состояния и разработки прогнозов возможных изменений экосистем, необходимы наблюдения, позволяющче качественно оценить их экологическое состояние. Интегральным выражением экологического состояния лимносистем выступают особенности химического состава вод, знание которых необходимо для решения вопроса интенсивного использования всех озерных ресурсов. Состав вод формируется под совокупным влиянием внутри- и вневодоемных прочессов (физических, химических и биологических), определяемых ландшафтными факторами лимногенеза, отражая зональную специфику условий формирования и внутризональную вариабельность. Взаимосвязь и взаимозависимость озера с водосбором, выражается в составе и количестве элементов химического состава вод, их распространении во времени, условиях миграции и трансформации. В статье на примере одного из районов Барабинской низменности рассмотрены возможности использования ландшафтноэкологического и геосистемно-лимнологического подхода к оценке состояния мальх водоемов. В качестве экологических параметров состояния разнотипных озер используются характеристики макрокомпонентного состава и основных гидрохимических показателей (рН, общей жесткости, минерализацчи), величины валовой концентрации элементов в воде озер и степень их геоэкофильности, особенности водной миграции. Отмечена роль факторов, обуславливающуих местные различия. В заключении отмечаются характерные черты региональной экологической обстановки в лимносистемах.
\end{abstract}

Ключевые слова: лимносистемы, экологическое состояние, Барабинская низменность, макрокомпоненты, водная миграция.

В условиях естественных и антропогенно-индуцированных изменений природы всё более актуальным становиться изучение динамики и функционирования экогеосистем основных зональных подразделений террито- рии и крупных геоморфологических образований, их устойчивость и восприимчивость внешнему воздействию [1]. Барабинская низменность (Бараба) представляет особый интерес с позиций контрастности природных

Бакаев Владимир Александрович - аспирант кафедры физической географии и туризма, Институт естественных и социально-экономических наук, Новосибирский государственный педагогический университет

E-mail: bakaev_dgn@mail.ru 
факторов, обусловленных географическим положением на стыке гумидной, семиаридной и аридной зон увлажнения. Типоморфные для неё озёрные геосистемы, как накапливающие элементы ландшафтов, являются наиболее чуткими индикаторами экологической обстановки в регионе, а разнообразие и сезонная цикличность свойств озёрных вод позволяет использовать количественные и качественные гидро- и геохимические параметры для диагностики состояния, как самих водоёмов, так и сформировавшей их ландшафтной среды.

Объектом исследования являлись лимносистемы трех озерных ландшафтов ОмьТартасского междуречья: Притарского редкоозёрного (оз. Данилино, Большой Карбалык, Кыштово), Омь-Тартасского озерноболотного (оз. Байдово) и Барабинского гривно-многоозерного (оз. Большой Агучак, Малый Агучак, Угуй) - приуроченные к району перехода от гидроморфных условий лесоболотной зоны к семиаридным типично лесостепным.

Озёра разнотипны по своему происхождению: Бол. Карбалык, Бол. Агучак, Угуй и Мал. Агучак относятся к генетическому типу суффозионных, Кыштово и Байдово - материковых, Данилино - долинных [2-3]. По параметрам морфометрии соответствуют трём морфолимническим типам, выделяемым В. В. Богдановым - литоральному (Бол. Агучак, Угуй, Мал. Агучак), литоральнопрофунтальному (Кыштово, Бол. Карбалык, Байдово) и профундальному (Данилино) [34]. Черты гидрологического режима определяют все вышеотмеченные водоемы как озера стоковой группы [5-6].

Пробы воды отбирались в летний период (июль - август 2013 г.). Анализ химического состава проводился в стационарных условиях на базе аккредитованной лаборато- рии «Аналитический центр» ФГБОУ ВПО «НГПУ» по известным методикам ${ }^{12345}$.

Теоретико-методологической основой исследования послужили фундаментальные работы в области гидрохимии и классификации природных вод О. А. Алекина [7], О. П. Оксиюк с соавторами [8], озероведения Б. Б. Богословского [5], В. В. Богданова [4], геохимии ландшафтов А. И. Перельмана [9], а

${ }^{1}$ ГОСТ 23268.3-78 Воды минеральные питьевые лечебные, лечебно-столовые и природные столовые. Методы определения гидрокарбонат-ионов (с Изменением № 1). - М.: Госком СССР по стандартам, 1978. - 5 с.

${ }^{2}$ ПНД Ф 14.1:2.159-2000 Количественный химический анализ вод. Методика выполнения измерений массовой концентрации сульфатионов в пробах природных и сточных вод турбидиметрическим методом. - М.: Госком РФ по охране окруж. среды, 2000. - 14 с.

${ }^{3}$ ПНД Ф 14.1:2:4.135-98 Количественный химический анализ вод. Методика выполнения измерений массовой концентрации элементов в пробах питьевой, природных, сточных вод и атмосферных осадков методом атомноэмиссионной спектрометрии с индуктивно связанной плазмой. - М.: Госком РФ по охране окруж. среды, 1998 (Изд. 2008). - 27 с.

${ }^{4}$ ПНД Ф 14.1:2:4.143-98 Количественный химический анализ вод. Методика измерений массовых концентраций алюминия, бария, бора, железа, калия, кальция, кобальта, магния, марганца, меди, натрия, никеля, стронция, титана, хрома и цинка в питьевых, природных и сточных водах методом ИСПспектрометрии. - М.: Федеральная Служба по надзору в сфере природопользования, 2011. $-18 \mathrm{c}$.

${ }^{5}$ ПНД Ф 14.12.96-97 Количественный химический анализ вод. Методика выполнения измерений массовой концентрации хлоридов в пробах природных и очищенных сточных вод аргентометрическим методом. - М.: Госком РФ по охране окруж. среды, 1997. - 9 с. 
Вестник Новосибирского государственного педагогического университета

5(21)2014 www.vestnik.nspu.ru ISSN 2226-3365

также частные региональные лимнологические изыскания [10-12].

Основные гидрохимические показатели ( $p H$, общая жесткость и минерализация) и особенности макрокомпонентного $\left(\mathrm{Ca}^{2+}\right.$, $\left.\mathrm{Mg}^{2+}, \mathrm{Na}^{+}, \mathrm{HCO}_{3}{ }^{-}, \mathrm{SO}_{4}{ }^{2-}, \mathrm{Cl}^{-}\right)$состава вод рассматриваемых озер представлены в табл. 1.

Активная реакция среды изменяется от нейтральной $(7,4$ ед. $p H)$ в материковых озеpax, до слабощелочной $(8,2$ ед. $p H)$ в северолесостепных суффозионных.

Содержание катионов неоднородно и существенно зависит от литологии и химического состава почв и почвообразующих пород водосборов, а также особенностей положения водоема в ландшафте. Так доминирование $\mathrm{Ca}^{2+}$ в материковых озерах междуречных пространств (Бол. Карбалык, Кыштово) постепенно замещается $\mathrm{Mg}^{2^{+}}$и $\mathrm{Na}^{+}$и их смешанными группами химизма в долинных озеpax (Данилино) и озерах межгривных понижений северной лесостепи (Бол. Агучак, Угуй, Мал. Агучак). Общая жесткость изменяется в интервале от 1,62 мг-экв/дм ${ }^{3}$ (мягкие воды) до 5,79 (воды средней жесткости).

По классификации О. А. Алекина воды рассматриваемых озер относятся к гидрокарбонатному типу, за исключением озера Угуй, для которого характерно преобладание вод хлоридного типа [7].

Таблица 1.

Основные гидрохимические показатели и макрокомпонентный состав

\begin{tabular}{|c|c|c|c|c|c|c|c|}
\hline \multirow[b]{2}{*}{ Показатель } & \multicolumn{7}{|c|}{ Озера } \\
\hline & Данилино & $\begin{array}{l}\text { Большой } \\
\text { Карбалык }\end{array}$ & Кыштово & Байдово & $\begin{array}{c}\text { Большой } \\
\text { Агучак }\end{array}$ & $\begin{array}{l}\text { Малый } \\
\text { Агучак }\end{array}$ & Угуй \\
\hline$p H$, ед. $p H$ & 7,90 & 7,80 & 7,40 & 7,60 & 8,00 & 8,20 & 7,80 \\
\hline $\mathrm{Ca}^{2^{+}}, \mathrm{M \Gamma} / \mathrm{дM}^{3}$ & 18,00 & 22,53 & 50,06 & 23,30 & 18,00 & 15,90 & 54,10 \\
\hline $\mathrm{Mg}^{2^{+}}, \mathrm{M \Gamma} / \mathrm{дM}^{3}$ & 15,80 & 6,10 & 11,69 & 34,20 & 18,20 & 10,01 & 37,60 \\
\hline $\mathrm{Na}^{+}+\mathrm{K}^{+}, \mathrm{M} \Gamma /$ дм $^{3}$ & 32,20 & 4,45 & 6,13 & 112,30 & 41,40 & 23,42 & 126,40 \\
\hline $\mathrm{HCO}_{3}{ }^{-}, \mathrm{M \Gamma} /$ дм $^{3}$ & 189,10 & 102,66 & 207,75 & 290,20 & 189,10 & 225,03 & 128,10 \\
\hline $\mathrm{SO}_{4}^{2^{-}}, \mathrm{M \Gamma} / \not \mathrm{M}^{3}$ & 12,30 & 4,30 & 8,90 & 39,60 & 12,30 & 8,38 & 164,50 \\
\hline $\mathrm{Cl}^{-}, \mathrm{мг} /$ дм $^{3}$ & 10,60 & 2,77 & 2,88 & 98,80 & 31,90 & 16,13 & 205,60 \\
\hline $\begin{array}{c}\text { Общая жесткость, } \\
\text { мг-экв/дм }\end{array}$ & 2,20 & 1,63 & 3,46 & 3,98 & 2,39 & 1,62 & 5,79 \\
\hline$\sum$ ионов, мг/дм & 278,00 & 142,81 & 287,41 & 598,40 & 310,90 & 298,87 & 716,30 \\
\hline $\begin{array}{c}\text { Индекс химизма } \\
\text { воды }\end{array}$ & $C_{I}^{\mathrm{Na}}$ & $C_{I I}^{C a}$ & $C_{I}^{C a}$ & $C_{I}^{N a}$ & $C_{I}^{\mathrm{NaMg}}$ & $C_{I I I}^{M g}$ & $C l_{I I}^{N a}$ \\
\hline
\end{tabular}

По величине минерализации представленные озера принадлежат к двум категориям: ультрапресные и пресные к $\alpha$ гипогалинным, с относительно повышенной минерализацией к $\beta$-олигогалинным [8].

Наряду с макрокомпонентным составом существенное значение имеет элементный состав вод, как важнейший компонент геохи- мической природы озер (табл. 2). Для характеристики экологического состояния озер по их элементному составу использованы несколько параметров: валовое содержание элемента в воде, степень его геоэкофильности и интенсивность водной миграции по А. И. Перельману. 


\begin{tabular}{|c|c|c|c|c|c|c|c|c|}
\hline \multirow{2}{*}{$\begin{array}{c}\text { Элемент, } \\
\text { мг/дм }{ }^{3}\end{array}$} & \multicolumn{8}{|c|}{ Озера } \\
\hline & Данилино & $\begin{array}{l}\text { Большой } \\
\text { Карбалык }\end{array}$ & Кыштово & Байдово & $\begin{array}{c}\text { Большой } \\
\text { Агучак }\end{array}$ & $\begin{array}{l}\text { Малый } \\
\text { Агучак }\end{array}$ & Угуй & ПДК ${ }_{\text {вр }}^{*}$ \\
\hline$M n$ & 0,05 & 0,018 & 0,019 & 0,003 & 0,003 & 0,03 & н/об & 0,01 \\
\hline $\mathrm{Fe}$ & 3,6 & 0,047 & 0,053 & 0,01 & 0,01 & 0,02 & 0,001 & 0,1 \\
\hline $\mathrm{Cu}$ & 0,004 & 0,0006 & 0,0008 & 0,003 & 0,008 & 0,0012 & 0,0008 & 0,001 \\
\hline $\mathrm{Zn}$ & 0,1 & 0,011 & 0,01 & 0,1 & 0,005 & 0,0024 & н/об & 0,01 \\
\hline$R b$ & 0,03 & 0,28 & 0,55 & 0,03 & 0,03 & 0,27 & 0,01 & 0,1 \\
\hline $\mathrm{Sr}$ & 0,4 & 0,011 & 0,022 & 0,1 & 0,09 & 0,011 & 0,01 & 0,4 \\
\hline Mo & 0,33 & 0,001 & 0,001 & 0,08 & 0,09 & 0,001 & 0,09 & 0,001 \\
\hline $\mathrm{Ni}$ & 0,002 & 0,0044 & 0,0022 & 0,016 & 0,014 & 0,0034 & н/об & 0,01 \\
\hline $\mathrm{Cr}$ & 0,0008 & н/об & н/об & 0,002 & 0,001 & н/об & 0,001 & 0,02 \\
\hline $\mathrm{Pb}$ & 0,0061 & 0,001 & 0,001 & 0,007 & 0,005 & 0,001 & 0,001 & 0,006 \\
\hline$C d$ & 0,0001 & н/об & н/об & 0,0001 & 0,0001 & н/об & н/об & 0,005 \\
\hline$S n$ & 0,002 & 0,01 & 0,062 & 0,002 & 0,002 & 0,013 & н/об & 0,112 \\
\hline $\mathrm{Ag}$ & 0,0005 & н/об & н/об & 0,0005 & 0,0005 & н/об & 0,0005 & 0,05 \\
\hline $\mathrm{Li}$ & 0,003 & 0,0033 & 0,0046 & 0,005 & 0,005 & 0,0049 & 0,002 & 0,08 \\
\hline Co & н/об & $<0,005$ & $<0,005$ & н/об & н/об & $<0,005$ & н/об & 0,01 \\
\hline$S i^{* *}$ & 2,2 & 1,43 & 1,1 & 0,126 & 1,2 & 1,33 & 2,38 & 10 \\
\hline$B$ & 0,31 & 0,045 & 0,089 & 0,42 & 0,09 & 0,033 & 0,29 & 0,5 \\
\hline$P$ & 0,0012 & 0,041 & 0,039 & 0,026 & 0,02 & 0,17 & 0,044 & 0,00001 \\
\hline$A l$ & 0,001 & 0,0046 & 0,01 & н/об & н/об & 0,01 & н/об & 0,04 \\
\hline \multicolumn{9}{|c|}{ 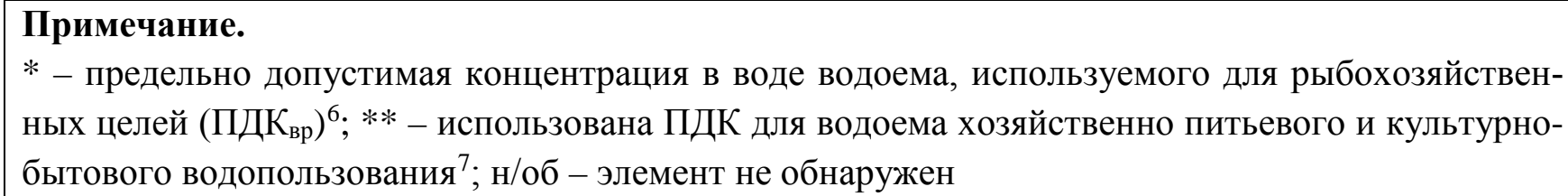 } \\
\hline
\end{tabular}

${ }^{6}$ Об утверждении нормативов качества воды водных объектов рыбохозяйственного значения, в том числе нормативов предельно допустимых концентраций вредных веществ в водах водных объектов рыбохозяйственного значения: приказ Федерального агентства по рыболовству от 18 января 2010 г. № 20 // Рос. газета. - 2010. - 5 марта (№ 5125). - С. 24.

${ }^{7}$ Постановление Главного государственного санитарного врача РФ от 30.04 .2003 № 78 (ред. от 16.09.2013) «О введении в действие ГН 2.1.5.1315-03» (вместе с «ГН 2.1.5.1315-03. Предельно допустимые концентрации (ПДК) химических веществ в воде водных объектов хозяйственнопитьевого и культурно-бытового водопользования. Гигиенические нормативы», утв. гл. гос. санитарным врачом РФ 27.04.2003) (Зарегистрировано в Минюсте России 19.05.2003 № 4550) [Электронный ресурс]: Режим доступа http://www.consultant.ru/document/cons_doc_ LAW_159629.html 
Распределение валовых концентраций элементов в целом отражает черты региональной биогеохимической ситуации [13]. Озера Притарского ландшафта (Данилино, Бол. Карбалык, Кыштово) содержат повышенное количество $\mathrm{Fe}$ (0.047-3.6 мг/дм $\left.{ }^{3}\right), \mathrm{Mn}$ (0.018-0.05 мг/дм $\left.{ }^{3}\right)$, Мо (0.001-0.33 мг/дм $\left.{ }^{3}\right)$. Это связано с повышенной увлажненностью климата территории, развитием процессов выщелачивания и оподзоливания почв, вследствие чего увеличивается вынос и аккумуляция этих металлов. Озеро Байдово, расположенное среди болотных массивов ОмьТартасского ландшафта, отмечается сравнительно повышенным содержанием $\mathrm{Zn}, \mathrm{Mo}, \mathrm{Ni}$ $\left(0.1,0.08,0.016\right.$ мг/дм ${ }^{3}$ соответственно), что вероятно обусловлено накоплением в водной толще большого количества органического вещества, связывающего ионы тяжелых металлов в растворимые металлоорганические комплексы, тем самым, способствуя их накоплению в лимнионе [14].

Для водоемов лесостепи характерно увеличение содержания $\mathrm{Cu} \quad(0.0012-0.008$ мг/дм $\left.{ }^{3}\right), P\left(0.02-0.17\right.$ мг/дм $\left.{ }^{3}\right)$, как следствие более активного и интенсивного использования водосборов (распашка, выпас скота и др.). Всем озерам присуще значимое содержание $\mathrm{Si}, \mathrm{B}, \mathrm{Sr}, \mathrm{Rb}$. Стоит отметить, что согласно полученным данным в водах изученных озер концентрации элементов находятся на уровне значений, приведенных для северных озер Евразии [15].

Следующий параметр - степень геоэкофильности элемента по В. В. Иванову, выражаемая как отношение содержания его в воде к эколого-гигиеническому показателю, т. е. полуколичественная оценка его геоэкологичности (токсичности) [16]. Для оценки использовались нормативы предельно допустимых концентраций вредных веществ для водоемов, пригодных для рыбохозяйственных це- лей. В соответствии с кратностью превышения, исследуемые элементы можно разбить на три группы: с кратностью превышения норматива значительно выше 10 раз - Мо, Р и $\mathrm{Fe}$ (превышение содержания железа отмечено в единичном случае на оз. Байдово); с кратность превышения от 1 до 10 раз $-R b, M n$, $\mathrm{Pb}, \mathrm{Cu}, \mathrm{Zn}, \mathrm{Ni}$; с кратностью превышения менее 1 - все остальные элементы.

Отмеченное выше позволяет вслед за В. Б. Ильиным и А. И. Сысо [17] отнести озера региона к территории относительного геохимического благополучия (богатство озерных вод микроэлементами) и экологического риска (несбалансированность содержания отдельных элементов, с возможным единичными примерами избытка).

Важным параметром является рассчитанный для каждого элемента коэффициент водной миграции по А. И. Перельману [9]. Он отражает интенсивность водной миграции, определяемую свойствами самого элемента, а также степень концентрации или рассеяния в лимногеосистеме (табл. 3).

В характеризуемых озерах наиболее активным водным мигрантом является $M o$, высокой интенсивностью миграции отличаются $B, R b, S n, A g, C d$. К активными агентами водной миграции можно отнести основные макроэлементы (Ca, $\mathrm{Mg}, \mathrm{Na}, \mathrm{K})$. Наименее подвижными участниками миграционногеохимических процессов являются $\mathrm{Al}$, Fe, $M n$. Отдельно стоит отметить особенности парной миграции отдельных элементов (Fe/Mn, $\mathrm{Ca} / \mathrm{Sr}$ ). Как правило, интенсивность миграции этих элементов относительно друг друга находится в диапазоне одного порядка, хотя в рассматриваемых водоемах отмечаются нарушения этой закономерности (поведение $\mathrm{Fe} / \mathrm{Mn}$ в водах оз. Бол. Карбалык, где сказывается влияние суходольной части водосбора, снижающей миграционную подвиж- 
ность $\mathrm{Mn}$; и взаимная миграция $\mathrm{Ca} / \mathrm{Sr}$ в о3. Угуй, где сказывается изменение класса химизма вод, уменьшая интенсивность миграции Sr). В целом параметры водной миграции соответствуют величинам определенным для Западной Сибири [12] и отдельных её регионов [11, 18], а также имеют схожие черты с миграционной обстановкой характерной для подобных регионов Европейской части России [19].

Таблица 3.

Интенсивность и коэффиц̧иент водной миграцчии

\begin{tabular}{|c|c|c|c|c|c|c|c|c|}
\hline \multirow{2}{*}{$\begin{array}{c}\text { Интенсивность } \\
\text { водной } \\
\text { миграции }\end{array}$} & \multirow[b]{2}{*}{$K_{\mathrm{x}}$} & \multicolumn{7}{|c|}{ Озера } \\
\hline & & Данилино & $\begin{array}{c}\text { Большой } \\
\text { Карбалык }\end{array}$ & Кыштово & Байдово & $\begin{array}{c}\text { Большой } \\
\text { Агучак }\end{array}$ & $\begin{array}{l}\text { Малый } \\
\text { Агучак }\end{array}$ & Угуй \\
\hline Очень слабая & $<0,001$ & Al & $A l$ & Al & $\mathrm{Fe}, \mathrm{Si}$ & $\mathrm{Fe}$ & Al & $\mathrm{Fe}$ \\
\hline & $\begin{array}{l}0,001- \\
0,01\end{array}$ & $P$ & $\mathrm{Fe}$ & $\mathrm{Fe}$ & $M n$ & $M n$ & $\mathrm{Fe}$ & - \\
\hline Слабая & $\begin{array}{l}0,01- \\
0,1\end{array}$ & $\mathrm{Si}, \mathrm{Cr}$ & $\mathrm{Si}, \mathrm{Cu}$ & $\begin{array}{l}\mathrm{Si}, \mathrm{Cu}, \mathrm{K} \\
\mathrm{Mn}\end{array}$ & $\mathrm{Cr}, P$ & Si, Cr, P & $\begin{array}{l}\mathrm{Si}, \mathrm{Cu}, \\
\mathrm{Zn}\end{array}$ & $\begin{array}{l}\mathrm{Si}, \mathrm{Cr}, \mathrm{Cu}, \\
\mathrm{Sr}, \mathrm{P}, \mathrm{Pb}, \\
\mathrm{Li}, \mathrm{Rb}\end{array}$ \\
\hline Средняя & $0,1-1$ & $\begin{array}{l}\mathrm{Ni}, \mathrm{Mn}, \mathrm{Fe}, \\
\mathrm{Cu}, \mathrm{Li}, \mathrm{Ca}, \\
\mathrm{Rb}, \mathrm{K}\end{array}$ & $\begin{array}{l}\mathrm{Mn}, \mathrm{Sr}, \quad \mathrm{P}, \\
\mathrm{Pb}, \mathrm{Ni}, \quad \mathrm{K}, \\
\mathrm{Na}, \mathrm{Li}, \mathrm{Zn}\end{array}$ & $\begin{array}{l}\mathrm{Ni}, \mathrm{P}, \mathrm{Pb}, \\
\mathrm{Sr}, \mathrm{Zn}, \mathrm{Li}, \\
\mathrm{Na}, \mathrm{Co}\end{array}$ & $\begin{array}{lr}\mathrm{Cu}, & \mathrm{Li}, \\
\mathrm{Rb}, & \mathrm{Ni}, \\
\mathrm{Sr}, & \mathrm{Mg}, \\
\mathrm{Pb} & \end{array}$ & $\begin{array}{lr}\mathrm{Zn}, \quad \mathrm{Li}, \\
\mathrm{Cu}, \quad \mathrm{Rb}, \\
\mathrm{Mg}, \mathrm{Ni}, \mathrm{Sr}\end{array}$ & $\begin{array}{ll}\mathrm{Mn}, & \mathrm{Sr} \\
\mathrm{Ni}, & \mathrm{Pb}, \\
K, \mathrm{P}, \mathrm{Co}\end{array}$ & $M g, K, N a$ \\
\hline \multirow{2}{*}{ Сильная } & 1-10 & $\begin{array}{l}\mathrm{Pb}, \mathrm{Na}, \mathrm{Sn} \\
\mathrm{Mg}, \mathrm{Sr}, \mathrm{Zn}\end{array}$ & $\begin{array}{l}\mathrm{Co}, \mathrm{Mg}, \mathrm{Ca}, \\
\mathrm{Mo}\end{array}$ & $\begin{array}{l}M g, \quad M o \\
\mathrm{Ca}\end{array}$ & $\begin{array}{lr}\mathrm{Sn}, & \mathrm{Na}, \\
\mathrm{Zn}, & \mathrm{K}, \\
\mathrm{Ca} & \end{array}$ & $\begin{array}{l}\mathrm{Pb}, \quad \mathrm{Sn}, \\
\mathrm{Na}, \mathrm{K}, \mathrm{Ca}\end{array}$ & $\begin{array}{l}\mathrm{Ca}, \quad \mathrm{Mg}, \\
\mathrm{Na}, \mathrm{Mo}, \\
\mathrm{Li}, \mathrm{Rb}, \mathrm{B}\end{array}$ & $\mathrm{Ca}, \mathrm{Ag}$ \\
\hline & 10-100 & $A g, C d, B$ & $R b, B, S n$ & $R b, B, S n$ & $\begin{array}{l}A g, \quad C d, \\
B\end{array}$ & $A g, B, C d$ & Sn & $B$ \\
\hline Очень сильная & $>100$ & Mo & - & - & Mo & Mo & - & $M o$ \\
\hline
\end{tabular}

Таким образом, экологическое состояние отмеченных озерных систем характеризуется наличием зональных черт и присутствием топологических отличий.

При переходе от озер Притарского ландшафта к водоемам Барабинского происходит заметное увеличение минерализации, смена классов химизма вод, изменение в ионном составе - доминирующий Ca замещается
$\mathrm{Mg}$ и $\mathrm{Na}$. Концентрации элементов в озерной воде неоднородны, наибольшая степень геоэкофильности присуща $\mathrm{Mo}, \mathrm{P}, \mathrm{Rb}, \mathrm{Mn}, \mathrm{Pb}, \mathrm{Cu}$, $\mathrm{Zn}, \mathrm{Ni}$, а кроме того встречаются единичные примеры избытка отдельных элементов. В особенностях водной миграции прослеживаются типичные для данного региона черты, под влиянием ландшафтных факторов отмечаются местные различия. 


5(21)2014 www.vestnik.nspu.ru ISSN 2226-3365

\section{СПИСОК ЛИТЕРАТУРЫ}

1. Нечаева Е. Г. Мониторинг вещественно-динамического состояния геосистем в познании физико-географического процесса // География и природные ресурсы. - 2007. - № 3. C. $108-116$.

2. Белецкая Н. П. Генетическая классификация озерных котловин Западно-Сибирской равнины // Геоморфология. - 1987. - № 1. - С. 50-58.

3. Савченко Н. В. Озера южных равнин Западной Сибири - Новосибирск: Изд-во СО РАН, 1997. - 183 c.

4. Богданов В. В. Морфолимнические типы озер и их роль во взаимоотношениях лимнических и терригенных факторов в озёрном круговороте // Проблемы региональной лимнологии. - Иркутск, 1979. - С. 3-20.

5. Богословский Б. Б. Озероведение. - М.: Изд-во Моск. ун-та, 1960. - 335 с.

6. Природные ресурсы Новосибирской области / сост. С. Г. Бейром, И. П. Васильев, И. М. Гаджиев и др. - Новосибирск: Наука, Сиб. отд-ние, 1986. - 215 с.

7. Алёкин О. А. Основы гидрохимии - Л., 1970. - 298 с.

8. Оксиюк О. П., Жукинский В. Н., Брагинский Л. П., Линник П. Н., Кузьменко М. И., Кленус В. Г. Комплексная экологическая классификация качества поверхностных вод суши // Гидробиол. журн. - 1993. - № 29 (4). - С. 62-76.

9. Перельман А. И. Геохимия ландшафта. - М., 1975. - 342 с.

10. Сайдакова Л. А. Закономерности лимногенеза Барабинской низменности на примере сапропелевых озер: автореф. дисс. ... канд. геогр. наук. - Л., 1990. - 19 с.

11. Бакаев В. А., Савченко Н. В. Зональные особенности гидрохимического состояния малых озер Новосибирской области // Мир науки, культуры, образования. - 2013. - № 5. - С. 430-434.

12. Савченко Н. В. Биогеохимический мониторинг лимногеосистем Западной Сибири и его основные итоги // Водные и экологические проблемы Сибири и Центральной Азии: Труды Всероссийской научной конференции $\mathrm{c}$ международным участием, посвященной 25-летнему юбилею Института водных и экологических проблем СО РАН: в 3 т. - Барнаул, 2012. - T. 3 - C. 106-111.

13. Ильин В. Б. Геохимическая ситуация на территории Обь-Иртышского междурелья // Почвоведение. - 2007. - № 12. - С. 1442-1451.

14. Moiseenko T. I., Dinu M. I., Gashkina N. A., Kremleva T. A. Metal speciation in natural waters and metal complexing with humic matter // Doklady Earth Sciences. - 2012. - T. 442. - № 2. - P. 267-271.

15. Reimann C., Caritat P. Chemical elements in the environment. - Springer-Verlag Berlin Heidelberg, 1998. -398 p.

16. Иванов В. В. Экологическая геохимия элементов: Справочник: В 6 кн. - М.: Недра, 1994. Кн.1: s-элементы. -304 с.

17. Ильин В. Б., Сысо А. И. Микроэлементы и тяжелые металлы в почвах и растениях Новосибирской области. - Новосибирск: Изд-во СО РАН, 2001. - 229 с.

18. Бакаев В. А. Современное состояние малых озёр Новосибирской области по данным геохимического и трофического мониторинга [электронный ресурс] // Вестник Новосибирского государственного педагогического университета. - 2013. - № 2. - С. 49-58. - Режим доступа: http://vestnik.nspu.ru/article/304 (дата обращения 01.08.2014).

19. Моисеенко Т. И., Гашкина Н. А. Формирование химического состава вод озер в условиях изменения окружающей среды. - Институт водных проблем РАН. - М., 2010. - 267 с. 
DOI: $10.15293 / 2226-3365.1405 .08$

Bakaev Vladimir Alexandrovich, Graduate of Faculty of Physical Geography and Tourism, Institute of Natural Social and Economic Sciences, Novosibirsk State Pedagogical University, Novosibirsk, Russian Federation.

E-mail: bakaev_dgn@mail.ru

\section{ENVIRONMENTAL STATUS LIMNOSISTEMS NORTH-WEST BARABA LOWLAND}

\section{Abstract}

For the diagnosis of the current state and development forecasts of possible changes in ecosystems are necessary observations to qualitatively assess their ecological status. Integral expression of the ecological state of limnosistems perform the chemical composition of water, knowledge of which is necessary to address the issue of intensive use of lake resources. Composition of water is formed under the combined influence of internal and external processes (physical, chemical and biological) defined landscape factors, reflecting zonal specific conditions of formation and intra-zonal variability. Interrelationship and interdependence of lake watershed, expressed in the composition and number of elements in the water chemistry, their distribution in time, the conditions of migration and transformation. On the example of one of the districts Baraba lowland considered the possibility of using landscape ecological and geosystem-limnological approach to assessing the state of small reservoirs. As an environmental condition parameters of different types of lakes are used macrocomponental characteristics and major hydro-chemical parameters ( $\mathrm{pH}$, total hardness, salinity), the gross value of the concentration of elements in the water of the lakes and their degree of geoenvironmental, especially water migration. The role of the factors causing local differences. In the conclusions of the regional characteristics of the environmental situation in limnosistems.

\section{Keywords}

limnosistems, ecological condition, Baraba lowland, macrocomponents, water migration

\section{REFERENCES}

1. Nechayeva E. G. Monitoring real-dynamic state of geosystems in the knowledge of physicalgeographical process. Geography and natural resources. 2007, no. 3, pp. 108-116. (In Russian)

2. Beletskaya N. P. Genetic classification of lake basins of the West Siberian Plain. Geomorphology. 1987, no. 1, pp. 50-58. (In Russian)

3. Savchenko N. V. Lake southern plains of Western Siberia. Novosibirsk, SB RAS Publ., 1997, 183 p. (In Russian)

4. Bogdanov V. V. Morfolimnology types of lakes and their role in the relationship and terrigenous limnological factors in the Lake cycling. Problems of regional limnology. Irkutsk, 1979, pp. 3-20. (In Russian)

5. Bogoslovsky B. B. Limnology. Moscow, University Press Publ., 1960, 335 p. (In Russian)

6. Natural resources of the Novosibirsk Region. Comp. S. G. Beiryom, I. P. Vasiliev, I. M. Gajiyev and others, Novosibirsk, Nauka Publ., 1986, 215 p. (In Russian)

7. Alyokin O. A. Fundamentals hydrochemistry. Leningrad, 1970, 298 p. (In Russian) 
8. Oksiyuk O. P., Zhukinsky V. N., Braginsky L. P., Linnik P. N., Kuzmenko M. I., Klenus V. G. Complex ecological quality classification of surface waters. Hidrobiol. Journal. 1993, no. 29 (4), pp. 62-76. (In Russian)

9. Perelman A. I. Geochemistry landscape. Moscow, 1975, 342 p. (In Russian)

10. Saydakova L. A. Regularities limnogenez Baraba lowland lakes sapropelic example: author's diss. ... candidate geogr. science. Leningrad, 1990, 19 p. (In Russian)

11. Bakaev V. A., Savchenko N. V. Zone features hydrochemical state of the small lakes of the Novosibirsk Region. World of science, culture and education. 2013, no. 5, pp. 430-434. (In Russian)

12. Savchenko N. V. Biogeochemical monitoring limnogeosistem Western Siberia and its main outcomes. Water and environmental problems of Siberia and Central Asia: Proceedings of the Scientific Conference with international participation, dedicated to the 25th anniversary of the Institute for Water and Environmental Problems: 3 vol. Barnaul, 2012, vol. 3, pp. 106-111. (In Russian)

13. Ilyin V. B. Geochemical situation on the territory of the Ob-Irtysh mezhdurelya. Soil. 2007, no. 12, pp. 1442-1451. (In Russian)

14. Moiseenko T. I., Dinu M. I., Gashkina N. A., Kremleva T. A. Metal speciation in natural waters and metal complexing with humic matter. Doklady Earth Sciences. 2012, vol. 442, no. 2, pp. 267-271.

15. Reimann C., Caritat P. Chemical elements in the environment. Springer-Verlag Berlin Heidelberg, 1998, $398 \mathrm{p}$.

16. Ivanov V. V. Environmental Geochemistry of Elements: Reference: In the book 6. Moscow, Nedra Publ., 1994, Book 1: s-elements, 304 p. (In Russian)

17. Ilyin V. B., Syso A. I. Trace elements and heavy metals in soils and plants of the Novosibirsk Region. Novosibirsk, SB RAS Publ., 2001, 229 p. (In Russian)

18. Bakaev V. A. The current status of small lakes in the Novosibirsk region according to the geochemical and trophic monitoring. Novosibirsk State Pedagogical University Bulletin. 2013, no. 2, pp. 49-58. Available at: http://vestnik.nspu.ru/article/304 (accessed: 01.08.2014). (In Russian)

19. Moiseenko T. I., Gashkina N. A. The chemical composition of lake waters in a changing environment. Moscow, Water Problems Institute of Russian Academy of Sciences Publ., 2010, 267 p. (In Russian) 


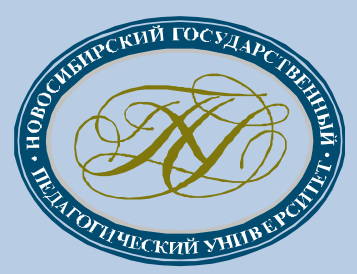

www.vestnik.nspu.ru

СОЦИАЛЬНО-ЭКОНОМИЧЕСКИЕ НАУКИ 


5(21)2014 www.vestnik.nspu.ru ISSN 2226-3365

(C) С. В. Сулима, О. Л. Чернобай

DOI: $10.15293 / 2226-3365.1405$

УДК 339.9

\title{
МЕЖДУНАРОДНЫЕ СВЯЗИ СУБЪЕКТОВ СИБИРСКОГО ФЕДЕРАЛЬНОГО ОКРУГА В ЭКОНОМИЧЕСКОЙ СФЕРЕ (НА ПРИМЕРЕ НОВОСИБИРСКОЙ ОБЛАСТИ И РЕСПУБЛИКИ КАЗАХСТАН)
}

\author{
С. В. Сулима (Актобе, Казахстан), О. Л. Чернобай (Новосибирск, Россия)
}

Международные связи Новосибирской области в торгово-экономической, инвестиционной, научно-технической, культурно-образовательной и иных сферах ежегодно расширяются. Высокий уровень развития внешнеэкономических и международных связей Новосибирской области способствует формированию региональных конкурентных преимуществ, а также созданию положительного имиджа Новосибирской области как региона с благоприятными условиями для проживания, отдыха, ведения бизнеса и инвестирования. Новосибирская область за последние годы приобрела значительный опыт в содействии предприятиям по реализации экспортных возможностей. Промышленная и инвестиционная политика в регионе направлена на формирование инновачионной среды, отличающейся значительным экспортным потенциалом.

Все виды международных связей регионов можно разделить на две крупные группы: приграничное и межтерриториальное сотрудничество. Приграничное сотрудничество осуществляется сопредельными регионами государств; межтерриториальное сотрудничество осуществляется несопредельными регионами государств. Приграничное сотрудничество - это согласованные действия, направленные на укрепление отномений между соседними регионами, находящимися под юрисдикиией разных государств.

Ключевые слова: международные связи регионов, приграничное сотрудничество, межтерриториальное сотрудничество, внешнеэкономическая деятельность, субъекты Сибирского федерального округа.

Новосибирская область входит в состав Сибирского федерального округа, граничит с Алтайским краем, Республикой Казахстан, Омской, Томской и Кемеровской областями. Площадь территории региона - 177,8 тыс. км$^{2}$ (1,1 \% территории России). Административный центр - город Новосибирск - самое крупное муниципальное образование Российской Федерации. Численность населения Новосибирска - свыше 1,523 млн человек,

Сулима Сергей Владимирович- кандидат экономических наук, заведующий кафедрой экономики, менеджмента и сервиса, Казахско-Русский Международный университет.

E-mail: sulima@rambler.ru

Чернобай Ольга Леонидовна - кандидат исторических наук, доцент кафедры общественных дисциплин, Сибирский институт международных отношений и регионоведения.

E-mail: olgachernobaj@yandex.ru 
численность населения области - 2,709 млн человек ${ }^{1}$.

В области интенсивно формируется инфраструктура внешнеэкономической деятельности, создан финансовый межрегиональный рынок, совершенствуется и расширяется выставочно-ярмарочная деятельность, работают зарубежные центры и представительства. В ближайшие годы планируется организовать выпуск новых видов продукции, востребованных на внешних рынках.

Важную роль в развитии торговоэкономических связей играет Новосибирская городская торгово-промышленная палата, объединяющая ведущие предприятия столицы Сибири. Внешнеторговые операции осуществляются с партнёрами из 110 стран дальнего и ближнего зарубежья [4, с. 133], при этом 73,7 \% стоимостного объёма внешнеторгового оборота приходится на торговлю c Германией, Болгарией, США, Китаем, Украиной, Казахстаном ${ }^{2}$. На всех мероприятиях с участием представителей органов исполнительной власти Новосибирской области, будь то выставка или торговоэкономическая миссия, большое внимание уделяется позиционированию нашей области как инвестиционно привлекательной. Как результат: сегодня Новосибирская область - это известный во всём мире регион Российской Федерации [7, с. 12]. Среди зарубежных

${ }^{1} \mathrm{X}$ Форум межрегионального сотрудничества Казахстана и России: Россия - Казахстан. Пути сотрудничества. 2013 год.

${ }^{2}$ Меморандум о сотрудничестве между Правительством Новосибирской области и Акиматом Павлодарской области от 6 июня 2012 года.

Соглашение о сотрудничестве между Министерством здравоохранения Новосибирской области и управлением здравоохранения Павлодарской области от июня 2012 года. партнёров Новосибирской области Казахстан занимает одно из первых мест по товарообороту (с 1999 года товарооборот вырос почти в три раза).

Все виды международных связей регионов можно разделить на две крупные группы: приграничное и межтерриториальное сотрудничество [5, с. 57]. Приграничное сотрудничество осуществляется сопредельными регионами государств; межтерриториальное сотрудничество осуществляется несопредельными регионами государств. Приграничное сотрудничество - это согласованные действия, направленные на укрепление отношений между соседними регионами, находящимися под юрисдикцией разных государств [5, с. 58]. Приграничное сотрудничество включает в себя также заключение международных соглашений. При осуществлении приграничных связей сотрудничество охватывает только те области, которые находятся в компетенции заинтересованных сообществ или властей. Основной целью приграничного сотрудничества является налаживание связей между приграничными территориями, поиск совместных решений схожих проблем [6, с. 16-17].

Приграничное сотрудничество Новосибирской области с Республикой Казахстан служит созданию благоприятных условий для развития сотрудничества в различных сферах деятельности между органами исполнительной власти, органами местного самоуправления приграничных территорий сопредельных областей, способствующих улучшению региональной экономики, ускорению интеграционных процессов и безопасности [3, с. 136].

Новосибирскую область и Республику Казахстан связывают многолетние дружественные отношения. Сотрудничество развивается в самых разных направлениях - в экономике, науке, образовании, культуре. И Казахстан, и Новосибирская область заинтере- 
сованы, в первую очередь, в развитии экономических отношений: расширении торговли, укреплении производственных кооперационных связей между промышленными предприятиями. На решении этих задач сосредоточены основные усилия органов государственной власти, предпринимательские инициативы.

В настоящее время действуют следующие соглашения:

- о торгово-экономическом, научнотехническом, социальном и культурном сотрудничестве - между администрацией Новосибирской области и акиматом Павлодарской области;

- социально-экономическом, научнотехническом и культурном сотрудничестве между Новосибирской и Карагандинской областями;

- экономическом и культурном сотрудничестве - между Новосибирской областью и Северо-Казахстанской областью;

- торгово-экономическом, социальном, научно-техническом и культурном сотрудничестве - между правительством Новосибирской области и акиматом ВосточноКазахстанской области.

Установлению новых контактов с Республикой Казахстан способствует регулярное участие новосибирских предприятий при поддержке правительства области в деловых встречах, презентациях и выставках, проводимых в региональных центрах и крупных городах Казахстана - Астане, Алматы, Павлодаре, Усть-Каменогорске, Семипалатинске, Караганде.

На территории Новосибирской области проживает 10705 казахов. Это шестой по численности этнос в регионе. Основная часть казахов проживает в приграничных с Казахстаном Купинском, Баганском и Карасукском районах.
Отдельно стоит отметить тесное сотрудничество Новосибирской области с приграничной Павлодарской областью Республики Казахстан: они соседствуют в месте прохождения российско-казахстанской государственной границы. На новосибирском участке границы функционируют федеральные пункты пропуска: многосторонний автомобильный «Павловка» (грузопассажирский), многосторонний железнодорожный «Карасук» (грузопассажирский), воздушный «Толмачёво» (грузопассажирский) - и определено шесть мест пересечения государственной границы [4, с. 133].

Руководство Новосибирской области ежегодно принимает участие в работе Форума межрегионального сотрудничества Республики Казахстан и Российской Федерации с участием глав государств [5, с. 57]. 4 октября 2007 года форум проходил в Новосибирске с участием Президента Российской Федерации В. Путина и Президента Республики Казахстан Н. Назарбаева. В рамках мероприятия были подписаны: соглашение о казахстанскороссийском сотрудничестве в области морского транспорта, программа экономического сотрудничества на 2008-2010 годы, программа сотрудничества в гуманитарной сфере на 2007-2010 годы, программа приграничного сотрудничества регионов Казахстана и России на 2008-2011 годы, протокол об основных направлениях сотрудничества таможенных служб на 2008 год, соглашение о сотрудничестве в приграничных регионах между «Внешэкономбанком» России, Банком развития Казахстана, администрацией Новосибирской области и акиматом Восточно- Казахстанской области [3, с. 135].

Новосибирская область принимает участие в мероприятиях по реализации Программы межрегионального и приграничного сотрудничества между Российской Федера- 
цией и Республикой Казахстан на 20122017 гг. В целях обеспечения согласованных действий исполнительных органов государственной власти Новосибирской области и территориальных органов федеральных органов исполнительной власти по развитию приграничного сотрудничества действует комиссия по развитию приграничного сотрудничества при правительстве Новосибирской области [5, с. 58]. Утверждена Концепция приграничного сотрудничества Новосибирской области до 2025 года ${ }^{3}$, целями которой являются развитие всесторонних процессов интеграции, улучшение социально-экономической обстановки, укрепление дружбы, добрососедства в приграничных районах и обеспечение безопасности на новосибирском участке российско-казахстанской границы.

Таким образом, рассмотрев международные связи Новосибирской области и Республики Казахстан в экономической сфере, можно прийти к выводу, что в целом структуру экспорта субъектов СФО определяют топливная промышленность, цветная и чёрная металлургия, химическая и нефтехимическая промышленность, энергетика, лесная и деревообрабатывающая промышленность. Однако здесь возникают серьёзные проблемы: плохое финансовое положение предприятий, утрата технологий и кадров в результате приватизации. Одни предприятия превращены в городские рынки, другие раздроблены, третьи выпускают непрофильную продукцию, даже авиазаводы и предприятия военнопромышленного комплекса и атомной промышленности [2, с. 162].

Несмотря на увеличение объёма импорта и положительное сальдо торгового баланса

\footnotetext{
${ }^{3}$ Утверждена распоряжением Губернатора Новосибирской области от 26 ноября 2009 года № 288-р. Более подробная информация на сайте: msp.nso.ru
}

Новосибирской области во внешнеэкономических операциях с Казахстаном, сегодня существуют проблемы в развитии приграничного сотрудничества [3, с. 134]. Несогласованность национальных законодательств, сохраняющиеся таможенные и налоговые барьеры сдерживают взаимопоставки продукции. Снижение таможенных барьеров во взаимной торговле и выравнивание железнодорожных тарифов позволит увеличить товарооборот и грузооборот между сопредельными областями, сократить время прохождения грузов через границу. Недостаток инвестиций и низкий уровень инвестиционного сотрудничества оказывает негативное действие на экономическое и социальное развитие приграничных районов. В приграничных районах разработаны инвестиционные проекты, созданы условия для инвесторов. Реализация инвестиционных проектов с участием инвесторов сопредельных областей позволит привлечь в экономику районов свободные трудовые, природные ресурсы, недоиспользованные производственные мощности. 


\section{СПИСОК ЛИТЕРАТУРЫ}

1. Имидж России: концепция национального и территориального брендинга / Сост. И. А. Василенко, Е. В. Василенко, В. Н. Ляпоров, А. Н. Люлько; под ред. И. А. Василенко. - М.: Экономика, 2012.

2. Плотникова О. В. Теория, система и практика международных связей регионов. - Новосибирск, 2004. - С. 162.

3. Плотникова О. В., Дубровина О. Ю. Глобализация и регионализация, их влияние на международное сотрудничество регионов государств // Общенациональный научнополитический журнал Власть. - № 2. - 2013. - С. 134.

4. Плотникова О. В. Регионализм: некоторые подходы к определению // Общенациональный научно-политический журнал Власть. - № 3. - 2012. - С. 132.

5. Дубровина О. Ю. Политический механизм регионального измерения внешней политики государств: понятие, структура, регулятивная составляющая политического механизма // Общенациональный научно-политический журнал Власть. - № 8. - 2014. - С. 57.

6. Плотникова О. В., Дубровина О. Ю. Международные связи регионов государств: теория и практика. - Новосибирск: Изд-во НГТУ, 2013. - С. 11.

7. Чернобай О. Л. Исторический опыт международного сотрудничества регионов Российской Федерации со странами ближнего и дальнего зарубежья в 1991-2000 годах (На примере Новосибирской области): автореф. дисс. ... канд. истор. наук. - Новосибирск, 2010.

8. Чернобай О. Л. Состояние и перспективы международного сотрудничества Новосибирской области со странами ближнего и дальнего зарубежья в 1996-2000 гг. // Вестник Новосибирского государственного педагогического университета - 2012. - № 1 (5). - С. 68-73. 
DOI: $10.15293 / 2226-3365.1405$

Sulima Sergey Vladimirovich, Candidate of Economical Sciences, Head of Department of Economy, Management and Service, Kazakh-Russian International University, Aktobe, Republic of Kazakhstan.

E-mail: sulima@rambler.ru

Chernobay Olga Leonidovna, Candidate of Historical Sciences, Associate Professor of the Department of Social Sciences, Siberian Institute of International Relations and Regional Studies, Novosibirsk, Russian Federation. E-mail: olgachernobaj@yandex.ru

\title{
INTERNATIONAL TIES OF THE SUBJECTS OF THE SIBERIAN FEDERAL DISTRICT IN THE ECONOMIC SPHERE
}

\section{(ON THE EXAMPLE OF THE NOVOSIBIRSK REGION AND THE REPUBLIC OF KAZAKHSTAN)}

\begin{abstract}
International relations of the Novosibirsk region in trade and economic, investment, scientific and technical, cultural, educational and other spheres are annually extending. The high level of development of foreign economic and international relations of the Novosibirsk region contributes to the formation of regional competitive advantages and the creation of positive image of the Novosibirsk region with favorable conditions for residence, leisure, business and investment. In recent years, the Novosibirsk region has gained considerable experience in promoting export opportunities of enterprises. Industrial and investment policy in the region is directed at formation of the innovation environment, characterized by strong export potential. All kinds of international relations of the regions can be divided into two major groups: cross-border and inter-territorial cooperation. Cross-border cooperation is implemented by adjacent regions of states; inter-territorial co-operation - by noncontiguous state regions. Cross-border cooperation means coordinated actions aimed at strengthening relations between neighboring regions under the jurisdiction of different states.
\end{abstract}

\section{Keywords}

International relations of the regions, cross-border cooperation, inter-territorial cooperation, foreign economic activity, subjects of the Siberian Federal district

\section{REFERENCES}

1. The image of Russia: concept of national and regional branding. Comp. I. A.Vasilenko, E. V. Vasilenko, V. N. Lyaporov, A. N. Lyulko. Moscow, Economics Publ., 2012. (In Russian)

2. Plotnikova O. V. Theory, system and practice of international relations of the regions. Novosibirsk, 2004, p. 162. (In Russian)

3. Plotnikova O. V., Dubrovina O. Y Globalization and regionalization, their impact on international cooperation of regions States. National scientific and political magazine of Power. no. 2, 2013, p. 134. (In Russian)

4. Plotnikova O. V. Regionalism: some approaches to the definition. National scientific and political magazine of Power. no. 3, 2012, p. 132. (In Russian) 
5. Dubrovina O. Y. Political mechanism for regional dimension of foreign policy: the concept, structure, regulatory component of the political system. National scientific and political magazine of Power. no. 8, 2014, p. 57. (In Russian)

6. Plotnikova O. V., Dubrovina O. Y. International relations of the state regions: theory and practice. Novosibirsk, 2013, p. 11. (In Russian)

7. Chernobay O. L. Historical experience of the international cooperation of regions of the Russian Federation with the countries of near and far abroad in 1991-2000 (On the example of the Novosibirsk region). Novosibirsk, 2010. (In Russian)

8. Chernobay O.L. Status and perspectives of international collaboration of the Novosibirsk region with the neighboring foreign countries in 1996-2000. Novosibirsk State Pedagogical University Bulletin, 2012, no. 1, pp. 68-73. (In Russian) 
УДК $334+332(571)$

\title{
МАЛОЕ ПРЕДПРИНИМАТЕЛЬСТВО В СИБИРСКОМ ФЕДЕРАЛЬНОМ ОКРУГЕ: СОВРЕМЕННОЕ СОСТОЯНИЕ И ТЕНДЕНЦИИ РАЗВИТИЯ
}

\begin{abstract}
Н. В. Ионова (Новосибирск, Россия)
В статье анализируется процесс развития малого предпринимательства в России. Цель статьи - показать территориальные диспропорции в развитии малого предпринимательства на примере субъектов Сибирского федерального округа. Раскрывается роль малого предпринимательства в экономике страны, конкретизируются критерии предприятий малого предпринимательства в России. На основе статистических показателей дан анализ экономической деятельности предприятий среднего и малого предпринимательства в экономике России в период с 2009 по 2011 гг. Раскрывается сущность соџиальных функций малого предпринимательства. Дается характеристика основных тенденций развития и особенностей малого предпринимательства в России. Согласно полученным результатам анализа статистических показателей подтверждается наличие значительной дифференциации российских регионов по уровню развития среднего и малого предпринимательства. Отмечается, что темпы развития малого и среднего бизнеса в России очень низки. Раскрываются основные факторы, обусловившие этот процесс. На основе статистических данных дается сравнительная характеристика темпов и уровня развития малого предпринимательства в субъектах Сибирского федерального округа.
\end{abstract}

Ключевые слова: малое предприятие, малое предпринимательство, мальй бизнес, темпь развития малого предпринимательства, уровень развития малого предпринимательства.

Малый бизнес - важный элемент рыночной экономики, без которого не может гармонично развиваться государство. Малый бизнес во многом определяет темпы экономического роста, структуру и качество валового национального продукта [7, 12].

В России к малым предприятиям относятся юридические лица, индивидуальные предприниматели и крестьянские (фермер- ские) хозяйства, средняя численность работников которых за предшествующий календарный год не должна превышать 100 человек включительно для малых предприятий и до 15 человек для микропредприятий. Выручка от реализации товаров (работ, услуг) за предшествующий календарный год не должна превышать: для малого бизнеса 400 млн рублей, для микропредприятий - 60 млн рублей $[4,7,11]$.

Ионова Наталья Владимировна - кандидат географических наук, доцент кафедры экономической географии и регионоведения Института естественных и социально-экономических наук, Новосибирский государственный педагогический университет.

E-mail: nv_ionova@mail.ru 
Вестник Новосибирского государственного педагогического университета

5(21)2014 www.vestnik.nspu.ru

ISSN 2226-3365

Однако данное требование можно конкретизировать:

в промышленности, строительстве и на транспорте к малым относятся предприятия, численность которых не превышает 100 человек;

в сельском хозяйстве - 60 человек;

в научно-технической сфере - 60 человек;

в оптовой торговле - 50 человек;

- в розничной торговле и бытовом обслуживании населения - 30 человек; в остальных отраслях и при осуществлении других видов деятельности - 50 человек.

Во многих промышленно развитых странах успешной деятельности малого бизнеса способствует государственная поддержка $[3-4,11]$.

Основные показатели экономической деятельности предприятий среднего и малого предпринимательства в экономике России в период с 2009 по 2011 гг. свидетельствуют о положительной динамике его развития (табл. 1).

Таблица 1.

Основные показатели экономической деятельности предприятий среднего и малого предпринимательства в экономике России, на конеи года (составлено по: [8; 10])

\begin{tabular}{|l|c|c|c|c|c|c|}
\hline \multirow{2}{*}{\multicolumn{1}{|c|}{ Показатель }} & \multicolumn{3}{|c|}{ Средние предприятия } & \multicolumn{3}{c|}{ Малые предприятия } \\
\cline { 2 - 8 } & $\mathbf{2 0 0 9}$ & $\mathbf{2 0 1 0}$ & $\mathbf{2 0 1 1}$ & $\mathbf{2 0 0 9}$ & $\mathbf{2 0 1 0}$ & $\mathbf{2 0 1 1}$ \\
\hline Число предприятий & 15547 & 25170 & 15856 & 1578769 & 1644269 & 1836433 \\
\hline $\begin{array}{l}\text { Средняя численность работников, } \\
\text { тыс. чел. }\end{array}$ & 2063,1 & 2582,9 & 2051,5 & 11281,7 & 11149,0 & 11480,5 \\
\hline Оборот предприятий, млрд руб. & 3030,5 & 7338,5 & 5102,9 & 16443,5 & 18301,3 & 22613,1 \\
\hline $\begin{array}{l}\text { Сальдированный финансовый ре- } \\
\text { зультат (прибыль минус убыток), } \\
\text { млрд руб. }\end{array}$ & 93,0 & 139,4 & 162,1 & 424,6 & 536,0 & 474,2 \\
\hline
\end{tabular}

Данные табл. 1 свидетельствуют о том, что за 2009 по 2011 гг. число предприятий и среднего, и малого предпринимательства в стране увеличилось примерно на $2 \%$ и $16 \%$, соответственно. При этом, если количество средних компаний с 2009 по 2010 гг. выросло примерно на $62 \%$, то к 2011 г. их количество снизилось на 63 \%. Оборот предприятий среднего бизнеса за анализируемый период времени увеличился примерно на $68 \%$, а рост прибыли составил почти 74 \%, малых компаний - примерно на 38 и $12 \%$, соответственно. Наибольшее число средних предприятий в 2011 г. приходилось на обрабатывающие производства - 19,6 \%, тогда как малых - на сферу торговли и бытового обслуживания 25,2 \% $[1,4]$. При этом наименьшее количество средних предприятий приходилось на образование (2 ед.) и связь $(0,3 \%)$, а малых компаний - на рыболовство и рыбоводство $(0,2 \%)$ (табл. 2). 
Вестник Новосибирского государственного педагогического университета

5(21)2014 www.vestnik.nspu.ru ISSN 2226-3365

Таблица 2.

Количество предприятий среднего и малого предпринимательства по видам экономической деятельности в России, в 2011 г. (составлено по: [10])

\begin{tabular}{|l|c|c|}
\hline \multicolumn{1}{|c|}{ Вид экономической деятельности } & $\begin{array}{c}\text { Средние } \\
\text { предприя- } \\
\text { тия }\end{array}$ & $\begin{array}{c}\text { Малые } \\
\text { предприя- } \\
\text { тия }\end{array}$ \\
\hline Всего из них: & 15945 & 1836433 \\
\hline сельское хозяйство, охота и лесное хозяйство & 3128 & 59903 \\
\hline рыболовство, рыбоводство & 79 & 3612 \\
\hline добыча полезных ископаемых & 260 & 6218 \\
\hline обрабатывающие производства & 3834 & 171269 \\
\hline производство и распределение электроэнергии, газа и воды & 362 & 11427 \\
\hline строительство & 1969 & 202579 \\
\hline $\begin{array}{l}\text { оптовая и розничная торговля; ремонт автотранспортных средств, мото- } \\
\text { циклов, бытовых изделий и предметов личного пользования }\end{array}$ & 3584 & 727341 \\
\hline гостиницы и рестораны & 197 & 53069 \\
\hline $\begin{array}{l}\text { транспорт и связь } \\
\text { из них связь }\end{array}$ & 721 & 114870 \\
\hline операции с недвижимым имуществом, аренда и предоставление услуг & 55 & 11598 \\
\hline образование & 1516 & 381438 \\
\hline здравоохранение и предоставление социальных услуг & 2 & 5701 \\
\hline предоставление прочих коммунальных, социальных и персональных услуг & 145 & 24906 \\
\hline
\end{tabular}

К числу социальных функций малого предпринимательства, следует отнести содействие вовлечению в производственный процесс дополнительных трудовых ресурсов, которые другими группами работодателей почти не используются (пенсионеры, несовершеннолетние, лица с ограниченной трудоспособностью, многодетные матери). Это тем более важно, учитывая, что доля данных категорий людей в общей численности населения страны увеличивается. Малые предприятия же, использующие наемный труд, гибко приспособлены для использования труда пожилых лиц, учащейся молодежи, надомников [7, 12].

Рост занятости населения и, соответственно, снижение уровня безработицы, повышение уровня жизни населения и сокращение бедных за счет вовлечения в сектор малого предпринимательства способствует реализации и других социальных функций малого бизнеса: противостоянию негативным социальным явлениям через сокращение преступности, алкоголизма, наркомании; возможности для самореализации людей с особой инициативой и предприимчивостью $[1-2,6]$.

Среди экономических преимуществ, способствующих развитию малого предпринимательства, можно выделить меньшую стоимость создания рабочих мест, высокую внутреннюю мобильность при изменении спроса с использованием местных ресурсов, неэффективных для крупного бизнеса, высокую рентабельность работы на «узких» сегментах рынка, ориентированных на ограниченный и специфичный круг потребителей, простоту организации, небольшой капитал при организации производства [2-3].

Тенденции развития малого предпринимательства в России: 
1. По итогам 2012 г. по сравнению с 2011 г. в целом по стране наблюдался рост основных показателей развития малого предпринимательства: количества малых предприятий, среднесписочной численности занятых на малых предприятиях, оборота малых предприятий и инвестиций в основной капитал.

2. На 1 января 2013 г. количество зарегистрированных малых предприятий по России увеличилось по сравнению с 1 января 2012 г. на $8,7 \%$, среднесписочная численность занятых на малых предприятиях выросла на $0,6 \%$, а удельный вес работников малых предприятий в общей среднесписочной численности занятых достиг уровня 22,6 \%. Объем оборота малых предприятий увеличился на $3,8 \%$, рост инвестиций в основной капитал на малых предприятиях составил 20,9\% [6, 12-13].

3. Наибольшее желание создать свой бизнес демонстрируют жители городов с населением от 500 тыс. до 1 млн человек - $6 \%$. Сравнение количества заинтересованных в создании собственного бизнеса в зависимости от типа поселения с аналогичными данными на 2009 г. показало, что в городах-миллионниках и городах с населением от 100 до 500 тыс. жителей количество тех, кто имеет предпринимательские намерения, за рассматриваемый период сократилось практически вдвое.

К основным особенностям российского малого предпринимательства можно отнести следующие его характеристики:

\section{1. Малочисленность малого предпри-} нимательства. С 2002 г. наблюдается положительная динамика роста численности малых предприятий. Происходившее в конце 1990-х гг., ежегодное падение на 2-4 \% численности малых предприятий было остановлено, и за год их прирост составил 4,5 \%. Это было обусловлено общей благоприятной экономической ситуацией в тот период, а также частично мерами, принятыми Правительством
РФ. В целом, за 1999-2005 гг. количество малых предприятий увеличилось на 11,2 \%. На начало 2006 г. было зарегистрировано 979,3 тыс. субъектов малого предпринимательства $[5,11]$.

Следует отметить ухудшение ситуации в развитии малого предпринимательства в период экономического кризиса, но к 2011 г. число малых предприятий превысило 1,6 млн ед. [15]. Однако данные показатели развития малого предпринимательства в России все равно остаются в несколько раз ниже, чем аналогичные показатели в экономически развитых странах. Общее количество предприятий малого предпринимательства в расчете на 1 тыс. жителей в нашей стране в 4-4,5 раза меньше, по сравнению с развитыми странами мира [1]. Лишь Москва и Санкт-Петербург по плотности малого предпринимательства приблизились к уровню Западной Европы. В российской экономике доля малых предприятий в общем числе предприятий составляет порядка $30 \%$, в то время как в странах Европейского сообщества порядка 70-90 \% [3].

\section{2. Незначительный вклад субъектов} малого предпринимательства в ВВП страны. Во всех экономически развитых странах предприятия малого предпринимательства производят более 60 \% ВВП, около $30 \%$ экспортной продукции, являются главным производителем всех товаров и услуг. В России же вклад малого предпринимательства в ВВП составляет менее $20 \%$.

\section{3. Незначительный вклад в обеспече-} ние занятости. К 2011 г. общая численность работников малых предприятий достигла 10,2 млн чел. [1]. Но по уровню занятости в секторе малого предпринимательства Российская Федерация все же отстает от развитых стран: от США и развитых стран Европы - в 3 раза (50-55 \% занято в малом предпринимательстве), от Японии - в 5 раз (80\%). Всего 
Вестник Новосибирского государственного педагогического университета

5(21)2014 www.vestnik.nspu.ru ISSN 2226-3365

$15,2 \%$ от экономически активного населения России занято в малом предпринимательстве $[1,9]$.

\section{4. Структура малых предприятий по} видам экономической деятельности. Структура малого предпринимательства в России характеризуется высокой долей предприятий, занятых в торговле. Это в два раза выше аналогичных показателей большинства развитых стран мира [1]. Доля малых предприятий, работающих в сфере услуг, наоборот, почти в два раза меньше.

Рассмотрим распределение предприятий среднего и малого предпринимательства по федеральным округам России (табл. 3 ).

Таблица 3.

Число предприятий среднего и малого предпринимательства по федеральным округам Российской Федерации в 2011 г., на конеи года (составлено по: [10])

\begin{tabular}{|l|c|c|c|c|}
\hline \multirow{2}{*}{\multicolumn{1}{c|}{ Федеральный округ }} & \multicolumn{2}{|c|}{ Средние предприятия } & \multicolumn{2}{c|}{ Малые предприятия } \\
\cline { 2 - 5 } & $\begin{array}{c}\text { всего, } \\
\text { в ед. }\end{array}$ & $\begin{array}{c}\text { в \% к } \\
\text { итогу }\end{array}$ & $\begin{array}{c}\text { всего, } \\
\text { в ед. }\end{array}$ & $\begin{array}{c}\text { в \% к } \\
\text { итогу }\end{array}$ \\
\hline Российская Федерация & 15945 & 100 & 1836433 & 100 \\
\hline Центральный федеральный округ & 4379 & 27,5 & 545540 & 29,7 \\
\hline Северо-Западный федеральный округ & 1596 & 10,0 & 259920 & 14,2 \\
\hline Южный федеральный округ & 1476 & 9,3 & 147379 & 8,0 \\
\hline Северо-Кавказский федеральный округ & 549 & 3,4 & 47646 & 2,6 \\
\hline Приволжский федеральный округ & 3554 & 22,3 & 336152 & 18,3 \\
\hline Уральский федеральный округ & 1314 & 8,2 & 173452 & 9,5 \\
\hline Сибирский федеральный округ & 2421 & 15,2 & 245064 & 13,3 \\
\hline Дальневосточный федеральный округ & 656 & 4,1 & 81280 & 4,4 \\
\hline
\end{tabular}

Таблица 4.

Система основных показателей уровня развития малых предприятий по федеральным округам Российской Федераџии в 2012 г. (составлено по: [10])

\begin{tabular}{|l|c|c|c|c|}
\hline Федеральный округ & $\begin{array}{c}\text { Количество } \\
\text { МП на 100 } \\
\text { тыс. жителей }\end{array}$ & $\begin{array}{c}\text { Доля занятых на } \\
\text { МП в общей средне- } \\
\text { списочной числен- } \\
\text { ности занятых, \% }\end{array}$ & $\begin{array}{c}\text { Объем оборота } \\
\text { МП на душу } \\
\text { населения, } \\
\text { руб. }\end{array}$ & $\begin{array}{c}\text { Инвестиции в основ- } \\
\text { ной капитал на МП } \\
\text { на душу населения, } \\
\text { руб. }\end{array}$ \\
\hline Центральный ФО & 1449,2 & 23,3 & 226579,0 & 3791,1 \\
\hline Северо-Западный ФО & 2369,8 & 24,6 & 185286,2 & 2018,1 \\
\hline Южный ФО & 1094,7 & 22,4 & 131055,5 & 5499,8 \\
\hline Северо-Кавказский ФО & 530,6 & 17,3 & 61812,0 & 1718,4 \\
\hline Приволжский ФО & 1202,7 & 23,7 & 141850,7 & 4521,0 \\
\hline Уральский ФО & 1511,0 & 20,4 & 177385,9 & 2164,8 \\
\hline Сибирский ФО & 1441,9 & 21,8 & 130082,1 & 4245,6 \\
\hline $\begin{array}{l}\text { Дальневосточный } \\
\text { ФО }\end{array}$ & 1478,7 & 20,2 & 144972,7 & 1973,5 \\
\hline
\end{tabular}


Вестник Новосибирского государственного педагогического университета

5(21)2014 www.vestnik.nspu.ru ISSN 2226-3365

Исходя из данных табл. 3, наибольшее количество и средних, и малых предприятий приходится на Центральный федеральный округ, а наименьшее количество - на СевероКавказский. Коэффициент дифференциации при этом составляет по средним предприятиям - 8 раз, а по малым - 11 раз. Таким образом, среди российских регионов наблюдается значительная дифференциация по уровню раз- вития среднего и малого предпринимательства $[11,15]$.

Существуют разные методы оценки уровня развития малого предпринимательства [14]. На основе имеющихся официальных статистических данных, отражающих уровень развития малых предприятий (табл. 4), нами было осуществлено ранжирование федеральных округов (ФО) (табл. 5).

Таблица 5.

Ранжирование федеральных округов Российской Федерации на основе системы основных показателей уровня развития малых предприятий в 2012 г. (рассчитано по данным табл. 4.)

\begin{tabular}{|l|c|c|c|c|c|}
\hline \multicolumn{1}{|c|}{ Федеральный округ } & Ранг 1 & Ранг 2 & Ранг 3 & Ранг 4 & $\begin{array}{c}\text { Сумма } \\
\text { рангов }\end{array}$ \\
\hline Центральный ФО & $\mathbf{4}$ & $\mathbf{3}$ & $\mathbf{1}$ & $\mathbf{4}$ & $\mathbf{1 2}$ \\
\hline Северо-Западный ФО & 1 & 1 & 2 & 6 & 10 \\
\hline Южный ФО & 7 & 4 & 6 & 1 & 18 \\
\hline Северо-Кавказский ФО & 8 & 8 & 8 & 8 & 32 \\
\hline Приволжский ФО & 6 & 2 & 5 & 2 & 15 \\
\hline Уральский ФО & 2 & 6 & 3 & 5 & 16 \\
\hline Сибирский ФО & 5 & 5 & 7 & 3 & 20 \\
\hline Дальневосточный ФО & 3 & 7 & 4 & 7 & 21 \\
\hline Примечание. Мах - 32; тіn - 12; «шаг»-5,5 \\
\hline
\end{tabular}

Существуют разные методы оценки уровня развития малого предпринимательства [14]. На основе имеющихся официальных статистических данных, отражающих уровень развития малых предприятий (табл. 4), нами было осуществлено ранжирование федеральных округов (ФО) (табл. 5).

По результатам ранжирования нами была осуществлена типология федеральных округов Российской Федерации по уровню развития малых предприятий в 2012 г. (табл. 6).

Таблица 6.

Типология федеральных округов Российской Федераиии по уровню развития малых предприятий в 2012 2. по результатам ранжирования (рассчитано по данным табл. 5)

\begin{tabular}{|c|c|c|l|}
\hline Тип & Интервал & $\begin{array}{c}\text { Уровень развития малых } \\
\text { предприятий }\end{array}$ & \multicolumn{1}{|c|}{ Федеральный округ } \\
\hline I & $12-15,5$ & Высокий & $\begin{array}{l}\text { Центральный, Северо-Западный, } \\
\text { Приволжский }\end{array}$ \\
\hline II & $15,51-20,5$ & Средний & Южный, Уральский, Сибирский \\
\hline III & $20,51-26,0$ & Ниже среднего & Дальневосточный \\
\hline IV & $26,1-32$ & Низкий & Северо-Кавказский \\
\hline
\end{tabular}


Вестник Новосибирского государственного педагогического университета

5(21)2014 www.vestnik.nspu.ru ISSN 2226-3365

В результате было выявлено, что в Сибирском федеральном округе (СФО) в 2012 г. уровень развития малых предприятий был средним. Сдерживающим фактором развития стал низкий объем оборота малых предприятий в СФО.
На основе имеющихся официальных статистических данных, отражающих темпы развития малых предприятий (табл. 7), нами было осуществлено ранжирование федеральных округов по темпам развития малых предприятий (табл. 8).

Таблица 7.

Система основных показателей отражающих темпы развития малых предприятий в федеральных округах Российской Федеращии в 2012 г. (составлено по: [10])

\begin{tabular}{|c|c|c|c|c|c|c|}
\hline $\begin{array}{c}\text { Федеральный } \\
\text { округ }\end{array}$ & $\begin{array}{c}\text { Измене- } \\
\text { ние коли- } \\
\text { чества } \\
\text { МП на } \\
100 \text { тыс. } \\
\text { жителей } \\
\text { в течение } \\
2012 \text { г. }\end{array}$ & $\begin{array}{c}\text { Количество } \\
\text { зарегистри- } \\
\text { рованных МП } \\
\text { в расчете на } \\
100 \text { тыс. чел. } \\
\text { населения, в } \\
\text { \% от среднего } \\
\text { по РФ }\end{array}$ & $\begin{array}{c}\text { Седне- } \\
\text { списоч- } \\
\text { ная чис- } \\
\text { ленность } \\
\text { работни- } \\
\text { ков МП, в } \\
\text { \% к } 2011 \\
\text { г. }\end{array}$ & $\begin{array}{c}\text { Изменение } \\
\text { доли заня- } \\
\text { тых на МП в } \\
\text { общей сред- } \\
\text { несписочной } \\
\text { численности } \\
\text { занятых от- } \\
\text { носительно } \\
2011 \text { г., п. п. }\end{array}$ & $\begin{array}{c}\text { Объем } \\
\text { обо- } \\
\text { рота } \\
\text { МП } \\
\text { в \% к } \\
2011 \text { г. }\end{array}$ & $\begin{array}{c}\text { Инвести- } \\
\text { ции в ос- } \\
\text { новной } \\
\text { капитал } \\
\text { на МП в } \\
\% \text { к } 2011 \\
\text { г. }\end{array}$ \\
\hline Центральный ФО & 30,2 & 103,8 & 97,8 & $-0,46$ & 87,7 & 119,1 \\
\hline $\begin{array}{l}\text { Северо-Западный } \\
\text { ФО }\end{array}$ & 462,3 & 169,8 & 99,7 & $-0,04$ & 99,9 & 113,2 \\
\hline Южный ФО & 30,7 & 78,4 & 100,5 & 0,28 & 105,3 & 107,6 \\
\hline $\begin{array}{l}\text { Северо-Кавказский } \\
\text { ФО }\end{array}$ & 25,8 & 38,0 & 105,9 & 0,97 & 107,2 & 119,0 \\
\hline Приволжский ФО & 77,7 & 86,2 & 103,0 & 0,83 & 109,4 & 115,7 \\
\hline Уральский ФО & 75,9 & 108,2 & 101,0 & 0,18 & 102,6 & 111,2 \\
\hline Сибирский ФО & 169,0 & 103,3 & 101,8 & 0,33 & 103,4 & 107,8 \\
\hline $\begin{array}{l}\text { Дальневосточный } \\
\text { ФО }\end{array}$ & 185,4 & 105,9 & 102,6 & 0,29 & 100,9 & 111,0 \\
\hline
\end{tabular}

Таблица 8.

Ранжсирование федеральных округов Российской Федерации по системе основных показателей отражающих темпы развития малых предприятий в 2012 г. (рассчитано по данным табл. 7)

\begin{tabular}{|l|c|c|c|c|c|c|c|}
\hline & Ранг 1 & Ранг 2 & Ранг 3 & Ранг 4 & Ранг 5 & Ранг 6 & Сумма рангов \\
\hline Центральный ФО & 7 & 4 & 8 & 8 & 8 & 1 & 36 \\
\hline Северо-Западный ФО & 1 & 1 & 7 & 7 & 7 & 4 & 27 \\
\hline Южный ФО & 6 & 7 & 6 & 5 & 3 & 8 & 35 \\
\hline Северо-Кавказский ФО & 8 & 8 & 1 & 1 & 2 & 2 & 22 \\
\hline Приволжский ФО & $\mathbf{4}$ & $\mathbf{6}$ & $\mathbf{2}$ & $\mathbf{2}$ & $\mathbf{1}$ & $\mathbf{3}$ & $\mathbf{1 8}$ \\
\hline Уральский ФО & 5 & 2 & 5 & 6 & 5 & 5 & 28 \\
\hline Сибирский ФО & 3 & 5 & 4 & 3 & 4 & 7 & 26 \\
\hline Дальневосточный ФО & 2 & 3 & 3 & 4 & 6 & 6 & 24 \\
\hline Примечание. Мах - 36; $\ln -18 ;$ «шаг»-4,5
\end{tabular}


Вестник Новосибирского государственного педагогического университета

5(21)2014 www.vestnik.nspu.ru ISSN 2226-3365

По результатам ранжирования нами была осуществлена типология федеральных округов Российской Федерации по темпам развития малых предприятий в 2012 г. (табл. 9).

Таблица 9.

Типология федеральных округов Российской Федераџии по темпам развития малых предприятий в 2012 г. по результатам ранжирования (рассчитано по данным табл. 8)

\begin{tabular}{|c|c|c|l|}
\hline Тип & Интервал & Темпы развития малых предприятий & \multicolumn{1}{|c|}{ Федеральный округ } \\
\hline I & $18-22,5$ & Высокие & Приволжский, Северо-Кавказский \\
\hline II & $22,51-27$ & Средние & Северо-Западный, Сибирский, Дальневосточный \\
\hline III & $27,1-31,5$ & Ниже среднего & Уральский \\
\hline IV & $31,51-36$ & Низкие & Центральный, Южный \\
\hline
\end{tabular}

В результате было выявлено, что в Сибирском федеральном округе в 2012 г. темпы развития малых предприятий были средними. Сдерживающим фактором развития стали низкие темпы роста объема инвестиций в основной капитал на малых предприятиях в СФО.

Для оценки уровня и темпов развития малого предпринимательства в субъектах Си- бирского федерального округа нами были проанализированы основные показатели, отражающие состояние малого предпринимательства в 2012 г. Система статистических показателей была переведена в систему относительных показателей (табл. 10). На основе относительных показателей была выявлена пространственная концентрация малого предпринимательства на территории СФО в 2012 г.

Таблица 10.

Доля субъектов СФО в основных показателях, отражающих состояние малого предпринимательства в 2012 г., в \% (рассчитано по: [10])

\begin{tabular}{|l|c|c|c|}
\hline \multicolumn{1}{|c|}{ Субъект } & $\begin{array}{c}\text { В среднесписочной чис- } \\
\text { ленности работников } \\
\text { MП }\end{array}$ & $\begin{array}{c}\text { В объеме оборота } \\
\text { МП }\end{array}$ & $\begin{array}{c}\text { В инвестициях в ос- } \\
\text { новной капитал на } \\
\text { МП }\end{array}$ \\
\hline Алтайский край & 12,67 & 10,69 & 16,54 \\
\hline Забайкальский край & 2,95 & 2,20 & 0,77 \\
\hline Иркутская область & 12,68 & $\mathbf{1 4 , 7 6}$ & 1,26 \\
\hline Кемеровская область & $\mathbf{1 4 , 2 5}$ & 12,95 & $\mathbf{2 7 , 4 4}$ \\
\hline Красноярский край & $\mathbf{1 6 , 1 3}$ & $\mathbf{1 5 , 5 6}$ & 13,93 \\
\hline Новосибирская область & $\mathbf{1 9 , 7 0}$ & $\mathbf{2 0 , 2 9}$ & 13,98 \\
\hline Омская область & 10,52 & 0,39 & 1,09 \\
\hline Республика Алтай & 0,76 & 2,58 & 0,75 \\
\hline Республика Бурятия & 3,11 & 0,27 & 0,067 \\
\hline Республика Тыва & 0,48 & 1,10 & 0,09 \\
\hline Республика Хакасия & 1,36 & 5,65 & 3,25 \\
\hline Томская область & 5,37 & 100 & 100 \\
\hline СФО & 100 & на 3 субъекта прихо- & на 2 субъекта прихо- \\
\hline & датся $50,61 \%$ & дится $51,42 \%$ \\
\hline
\end{tabular}


Вестник Новосибирского государственного педагогического университета

5(21)2014 www.vestnik.nspu.ru ISSN 2226-3365

В 2012 г. отмечалась пространственная концентрация малого предпринимательства на территории СФО:

1) на три субъекта СФО (Новосибирская область, Красноярский край, Кемеровская область) приходилось $50 \%$ среднесписочной численности работников МП;

2) на три субъекта СФО (Новосибирская область, Красноярский край, Иркутская область) приходилось 50 \% всего оборота МП;

3) на два субъекта СФО (Новосибирская область, Кемеровская область) приходилось $51 \%$ всех инвестиций в основной капитал на МП.

В 2012 г. абсолютным лидером по деятельности малых предприятий на территории
СФО была Новосибирская область, что вполне объяснимо, поскольку Новосибирск является самым крупным муниципальным образованием в Российской Федерации. Так же выделяются Красноярский край и Кемеровская область - субъекты, лидирующие в СФО по основным социально-экономическим показателям.

На основе имеющихся официальных статистических данных, отражающих уровень развития малых предприятий (табл. 11), нами было осуществлено ранжирование субъектов СФО (табл. 12). По результатам ранжирования было выявлено, что лидером по уровню развития малых предприятий на территории СФО в 2012 г. была Новосибирская область, а аутсайдером - Республика Тыва.

Таблица 11.

Система основных показателей уровня развития мальх предприятий в субъектах СФО в 2012 г. (составлено по: [10])

\begin{tabular}{|l|c|c|c|c|}
\hline \multicolumn{1}{|c|}{ Субъект } & $\begin{array}{c}\text { Количество } \\
\text { МП на 100 } \\
\text { тыс. жителей }\end{array}$ & $\begin{array}{c}\text { Доля занятых } \\
\text { на МП в об- } \\
\text { щей средне- } \\
\text { списочной } \\
\text { численности } \\
\text { занятых, \% }\end{array}$ & $\begin{array}{c}\text { Объем оборота } \\
\text { МП на душу } \\
\text { населения в \% } \\
\text { от среднего по } \\
\text { РФ }\end{array}$ & $\begin{array}{c}\text { Инвестиции в ос- } \\
\text { новной капитал на } \\
\text { МП на душу насе- } \\
\text { ления, в \% от сред- } \\
\text { него по РФ }\end{array}$ \\
\hline Алтайский край & 1488,2 & 24,7 & 80,0 & 181,9 \\
\hline Забайкальский край & 491,5 & 12,3 & 33,5 & 17,2 \\
\hline Иркутская область & 1024,0 & 21,6 & 96,7 & 12,1 \\
\hline Кемеровская область & 1219,2 & 20,2 & 85,5 & 266,0 \\
\hline Красноярский край & 1803,5 & 20,6 & 78,9 & 103,7 \\
\hline Новосибирская область & 2240,6 & 28,9 & 114,0 & 197,9 \\
\hline Омская область & 1333,2 & 23,6 & 123,7 & 112,4 \\
\hline Республика Алтай & 1199,5 & 18,4 & 27,2 & 17,1 \\
\hline Республика Бурятия & 1057,1 & 16,9 & 40,0 & 5,1 \\
\hline Республика Тыва & 494,3 & 8,8 & 14,1 & 4,0 \\
\hline Республика Хакасия & 1073,4 & 12,4 & 33,5 & 67,9 \\
\hline Томская область & 1928,8 & 21,9 & 80,4 & \\
\hline
\end{tabular}


Вестник Новосибирского государственного педагогического университета

5(21)2014 www.vestnik.nspu.ru ISSN 2226-3365

Таблица 12.

Ранжсирование субъектов СФО по системе основных показателей, отражаюших уровень развития мальх предприятий в 2012 г. (рассчитано по данным табл. 11)

\begin{tabular}{|l|c|c|c|c|c|}
\hline \multicolumn{1}{|c|}{ Субъект } & Ранг 1 & Ранг 2 & Ранг 3 & Ранг 4 & Сумма рангов \\
\hline Алтайский край & 4 & 2 & 6 & 3 & 15 \\
\hline Забайкальский край & 12 & 11 & 10 & 8 & 41 \\
\hline Иркутская область & 10 & 5 & 3 & 10 & 28 \\
\hline Кемеровская область & 6 & 7 & 4 & 1 & 18 \\
\hline Красноярский край & 3 & 6 & 7 & 6 & 22 \\
\hline Новосибирская область & $\mathbf{1}$ & $\mathbf{1}$ & $\mathbf{2}$ & $\mathbf{2}$ & $\mathbf{6}$ \\
\hline Омская область & 5 & 3 & 1 & 4 & 31 \\
\hline Республика Алтай & 7 & 8 & 11 & 5 & 35 \\
\hline Республика Бурятия & 9 & 9 & 8 & 9 & 46 \\
\hline Республика Тыва & 11 & 12 & 12 & 11 & 39 \\
\hline Республика Хакасия & 8 & 10 & 9 & 12 & 18 \\
\hline Томская область & 2 & 4 & 5 & 7 & \\
\hline Примечание. Мах - 46; $\min -6 ;$ «шаг»-10 & & & & \\
\hline
\end{tabular}

По результатам ранжирования нами была осуществлена типология субъектов СФО
РФ по уровню развития малых предприятий в 2012 г. (табл. 13).

Таблица 13.

Типология субъектов СФО по уровню развития малых предприятий в 2012 г. по результатам ранжирования (рассчитано по данным табл. 12)

\begin{tabular}{|c|c|c|l|}
\hline Тип & Интервал & Уровень развития малых предприятий & \multicolumn{1}{|c|}{ Субъект СФО } \\
\hline I & $6-16$ & Высокий & $\begin{array}{l}\text { Алтайский край, Новосибирская область, } \\
\text { Омская область }\end{array}$ \\
\hline II & $16,1-26$ & Средний & $\begin{array}{l}\text { Томская область, Кемеровская область, } \\
\text { Красноярский край }\end{array}$ \\
\hline III & $26,1-36$ & Ниже среднего & $\begin{array}{l}\text { Иркутская область, Республика Алтай, } \\
\text { Республика Бурятия }\end{array}$ \\
\hline IV & $36,1-46$ & Низкий & $\begin{array}{l}\text { Забайкальский край, Республика Тыва, } \\
\text { Республика Хакасия }\end{array}$ \\
\hline
\end{tabular}

Следовательно, субъекты СФО существенно отличаются по уровню развития малого предпринимательства и вполне закономерно, что высокий и средний уровень развития отмечается в субъектах, на территории которых размещаются города-миллионники или на рассматриваемый период осуществлялась реализация региональных программ по развитию малого и среднего предпринимательства.
На основе имеющихся официальных статистических данных, отражающих темпы развития малых предприятий (табл. 14), нами было осуществлено ранжирование субъектов СФО (табл. 15). По результатам ранжирования было выявлено, что лидером по темпам развития малых предприятий на территории СФО в 2012 г. была Кемеровская область, а аутсайдером - Забайкальский край. 
Вестник Новосибирского государственного педагогического университета

5(21)2014 www.vestnik.nspu.ru ISSN 2226-3365

Таблица 14.

Система основных показателей отражающих темпы развития мальх предприятий в субъектах СФО в 2012 г. (составлено по: [10])

\begin{tabular}{|l|c|c|c|c|}
\hline \multicolumn{1}{|c|}{ Субъект } & $\begin{array}{c}\text { Изменение коли- } \\
\text { чества МП на 100 } \\
\text { тыс. жителей по } \\
\text { сравнению с 2011 } \\
\mathbf{r .}\end{array}$ & $\begin{array}{c}\text { Изменение доли занятых } \\
\text { на МП в общей средне- } \\
\text { списочной численности } \\
\text { занятых относительно } \\
\mathbf{2 0 1 1} \text { г., п. п. }\end{array}$ & $\begin{array}{c}\text { Объем } \\
\text { оборота } \\
\text { МП в \% } \\
\text { к 2011 г. }\end{array}$ & $\begin{array}{c}\text { Инвестиции } \\
\text { в основной } \\
\text { капитал на } \\
\text { МП в \% к } \\
\mathbf{2 0 1 1} \text { г. }\end{array}$ \\
\hline Алтайский край & 183,1 & $-0,12$ & 94,2 & 145,9 \\
\hline Забайкальский край & $-165,2$ & $-3,74$ & 90,2 & 137,6 \\
\hline Иркутская область & 48,4 & 1,49 & 112,5 & 98,9 \\
\hline Кемеровская область & 158,4 & 1,10 & 119,4 & 125,2 \\
\hline Красноярский край & 538,7 & 0,78 & 100,8 & 121,9 \\
\hline Новосибирская область & $-90,3$ & 0,79 & 93,2 & 92,6 \\
\hline Омская область & 138,4 & 0,28 & 108,4 & 91,7 \\
\hline Республика Алтай & 148,3 & $-0,12$ & 99,0 & 42,9 \\
\hline Республика Бурятия & 139,8 & $-1,41$ & 114,1 & 116,9 \\
\hline Республика Тыва & $-4,2$ & 0,21 & 102,0 & 10,4 \\
\hline Республика Хакасия & 375,1 & $-2,09$ & 98,2 & 17,4 \\
\hline Томская область & 461,2 & $-0,48$ & 108,8 & 76,1 \\
\hline
\end{tabular}

Таблица 15.

Ранжирование субъектов СФО по системе основных показателей отражающих темпы развития малых предприятий в 2012 2. (рассчитано по данным табл. 14)

\begin{tabular}{|l|c|c|c|c|c|}
\hline \multicolumn{1}{|c|}{ Субъект } & Ранг 1 & Ранг 2 & Ранг 3 & Ранг 4 & Сумма рангов \\
\hline Алтайский край & 4 & 7 & 10 & 1 & 22 \\
\hline Забайкальский край & 12 & 12 & 12 & 2 & 38 \\
\hline Иркутская область & 9 & 1 & 3 & 6 & 19 \\
\hline Кемеровская область & $\mathbf{5}$ & $\mathbf{2}$ & $\mathbf{1}$ & $\mathbf{3}$ & $\mathbf{1 1}$ \\
\hline Красноярский край & 1 & 4 & 7 & 4 & 16 \\
\hline Новосибирская область & 11 & 3 & 11 & 7 & 32 \\
\hline Омская область & 8 & 5 & 5 & 8 & 26 \\
\hline Республика Алтай & 6 & 8 & 8 & 10 & 32 \\
\hline Республика Бурятия & 7 & 10 & 2 & 5 & 24 \\
\hline Республика Тыва & 10 & 6 & 6 & 12 & 34 \\
\hline Республика Хакасия & 3 & 11 & 9 & 11 & 24 \\
\hline Томская область & 2 & 9 & 4 & 9 & \\
\hline Примечание. Мах - 38; $\min -11 ;$ «шаг»-6,75 \\
\hline
\end{tabular}

По результатам ранжирования нами была осуществлена типология субъектов
СФО Российской Федерации по темпам развития малых предприятий в 2012 г. (табл. 16). 
Типология субъектов СФО по темпам развития мальх предприятий в 2012 г. по результатам ранжирования (рассчитано по данным табл. 15)

\begin{tabular}{|c|c|c|l|}
\hline Тип & Интервал & $\begin{array}{c}\text { Темпы развития ма- } \\
\text { лых предприятий }\end{array}$ & \multicolumn{1}{c|}{ Субъект СФО } \\
\hline I & $11-17,75$ & Высокие & Кемеровская область, Красноярский край \\
\hline II & $17,76-24,5$ & Средние & $\begin{array}{l}\text { Алтайский край, Иркутская область, Респуб- } \\
\text { лика Бурятия, Томская область }\end{array}$ \\
\hline III & $24,51-31,25$ & Ниже среднего & Омская область \\
\hline IV & $31,26-38$ & Низкие & $\begin{array}{l}\text { Забайкальский край, Новосибирская область, } \\
\text { Республика Алтай, Республика Тыва, Рес- } \\
\text { публика Хакасия }\end{array}$ \\
\hline
\end{tabular}

Следовательно, субъекты СФО существенно отличаются и по темпам развития малого предпринимательства, что вполне закономерно, поскольку высокий и средний уровень развития отмечается в субъектах, на территории которых размещаются крупнейшие федерального и международного значения сырьевые базы. Именно эти субъекты и становятся привлекательными для инвесторов и для реализации региональных программ развития. Однако следует отметить, что в шести из 12 субъектов СФО в 2012 г. темпы развития малого предпринимательства были низкими. Это свидетельствует о существовании целого ряда факторов, сдерживающих или даже тормозящих развитие малого предпринимательства в таких субъектах как Новосибирская и Омская области.

\section{СПИСОК ЛИТЕРАТУРЫ}

1. Биктуганова Г. Ф., Еникеева Д. Д. О некоторых особенностях малого бизнеса России // Экономика и социум. - 2013. - № 2 (7). - [Электронный ресурс]. - Режим доступа: http://www.iupr.ru (дата обращения: 14.11.2013).

2. Бухвальд Е., Виленский А. Услуги в системе государственной поддержки малого и среднего предпринимательства // Вестник института экономики РАН. - 2012. - № 4. - С. 36-50.

3. Гишкаева Л. Л. Значение и развитие структур среднего и малого предпринимательства в экономике России // Проблемы современной экономики. - 2013. - № 2 (46). - С. 146-149. [Электронный ресурс]. - Режим доступа: http://www.m-economy.ru/art.php?nArtId=4549 (дата обращения: 14.11.2013).

4. Гурьянов П. А. Критерии определения размеров малого и среднего бизнеса // Экономика, предпринимательство и право. - 2011. - № 10. - С. 3-12.

5. Гурьянов П. А. Малое предпринимательство в России в 2008-2012 гг.: период разочарования // Современные научные исследования и инновации. - 2013. - № 6. - [Электронный ресурс]. Режим доступа: http://web.snauka.ru/issues /2013/06/24896 (дата обращения: 13.01.2014).

6. Крейденко Т. Ф., Миронова М. Н. Малое предпринимательство в России: современные особенности, региональные диспропорции и тенденции развития // Региональная экономика: теория и практика. - 2011. - № 32. - С. 12-20. 
7. Курс экономической теории: учеб. пособие / рук. авт. коллектива и науч. ред. А. В. Сидоровича; МГУ им. М. В. Ломоносова. - 3-е изд., перераб. и доп. - М.: Дело и сервис, 2007. $1040 \mathrm{c}$.

8. Малое и среднее предпринимательство в России - 2010 г.: стат. сборник. - М.: Росстат, 2011. - [Электронный ресурс]. - Режим доступа: http://www.gks.ru/bgd/regl/b12_47/Main.htm (дата обращения: 13.11.2013).

9. Майорова Л. Н. Исследование основных проблем развития малого и среднего предпринимательства // Теория и практика общественного развития. - 2013. - № 3. - С. 219-222.

10. Малое и среднее предпринимательство России. 2012. - М.: Росстат, 2012. - [Электронный pecypc]. - Режим доступа: http://www.gks.ru/wps/wcm/connect/rosstat_main/rosstat/ru/ statistics/ publications/catalog/doc_1139841601359 (дата обращения: 14.11.2013).

11. Сайдуллаев Ф. С. Динамика развития малого предпринимательства в регионах России в 2012 году // Ежеквартальный информационно-аналитический доклад. - М.: НИСИПП, 2013. 35 с. - [Электронный ресурс]. - Режим доступа: http://www.nisse.ru (дата обращения: 14.11.2013).

12. Статистика малого и среднего предпринимательства в России: ключевые показатели, динамика сектора МСП (2008-2011гг.) // Ресурсный центр малого предпринимательства Noncommercial Foundation Russian SME Resource Centre - [Электронный ресурс]. - Режим доступа: http://www.rcsme.ru/ru/library/list/130/id (дата обращения: 14.11.2013).

13. Суглобов А. Е., Бобошко В. И. Основные тенденции развития малого предпринимательства в России // Региональная экономика: теория и практика. - 2008. - № 19. - С. 2-11.

14. Филиппов Д. В. Методика оценки уровня развития предпринимательства в регионе // Государственное управление. Электронный вестник. - 2013. - № 36. - С. 252-262. [Электронный pecypc]. - Режим доступа: http://www.e-journal.spa.msu.ru (дата обращения: 13.11.2013).

15. Царев В. В. Оценка стоимости бизнеса. Теория и методология: учеб. пособие для студентов вузов. - М.: ЮНИТИ-ДАНА, 2007. -478 с. 
Ionova Natalya Vladimirovna, Candidate of Geographic Sciences, Associate Professor of the Department of economic Geography and regional Studies, Institute of Natural and Social-Economic Sciences, Novosibirsk State Pedagogical University, Novosibirsk, Russian Federation.

E-mail:nv_ionova@mail.ru

\section{SMALL BUSINESS IN SIBERIAN FEDERAL DISTRICT: CURRENT STATE AND TENDENCIES OF THE DEVELOPMENT}

\section{Abstract}

This study aimed to analyze a small business in Russia. Paper investigates the territorial disproportions in development of a small business on the example of territorial subjects of Siberian Federal District. The role of small business in national economy reveals and the criteria of enterprises of small business in Russia are concretized.

The analysis of economic activity of average and small business enterprises in economy of Russia during the period from 2009 to 2011 is given on the basis of modern statistics. The essence of social functions of small business is discussing in this paper, including a characteristic of the main tendencies of development and features of small business in the Russian Federation. The average and small business enterprises are studied by the author according to the obtained results of the analysis of statistics data of a considerable differentiation of the regions of Russia. The author notes that the rates of small and medium sized business' development are low. Author shows major factors which have caused this process. The comparative characteristics of rates and a level of development of small business in territorial subjects of Siberian Federal District are given on the basis of statistical data.

\section{Keywords}

small enterprise, small business, rates of development of small business, level of development of small business

\section{REFERENCES}

1. Biktuganova G. F., Enikeeva D. D. Some peculiarities of a small business in Russia. Economics and socium. 2013, no. 2 (7). Available at: http:// http://www.iupr.ru (accessed: 14.11.2013). (In Russian)

2. Bukhvald E. M., Vilensky A. V. Services in a system of small and medium business state support. Russian Academy of Sciences Institute of Economics Bulletin. 2012, no. 4, pp. 36-50. (In Russian)

3. Gishkaeva L. L. An importance and development of medium sized and small business' structure in the economics of Russia. Problems of modern economics. 2013, no. 2 (46), pp. 146-149. Available at: http://www.m-economy.ru/art.php?nArtId=4549 (accessed: 14.11.2013). (In Russian)

4. Guryanov P. A. Criterias of small and medium business sizing. Economics, Entrepreneurship and Law. 2011, no. 10, pp. 3-12. (In Russian)

5. Guryanov P. A. Small business in Russian Federation in 2008-2012: Disappointment period. Modern Scientific Researchers and Innovations. 2013, no. 6. Available at: http://web.snauka.ru/issues/2013/06/24896 (accessed: 13.01.2014). (In Russian)

6. Kreydenko T. F., Mironova M. N. Small business in Russia: modern features, regional disproportions and development tendencies. Regional economics: theory and practice. 2011, no. 32, pp.12-20. (In Russian) 
7. Course of economic theory: manual. Ed. by A. V. Sidorovich, Lomonosov MSU. 3-rd edition, Moscow, Business and service Publ., 2007, 1040 p. (In Russian)

8. Small and middle sized business in Russia - 2010: statistic data. Moscow, Russian State Statistics Service Publ., 2011. Available at: http://www.gks.ru/bgd/regl/b12_47/Main.htm (accessed: 13.11.2013). (In Russian)

9. Mayorova L. N. Research on main problems of development of small and middle sized business development. Theory and Practice of social development. 2013, no. 3, pp. 219-222. (In Russian)

10. Small and medium sized enterprises in the Russian Federation. 2012. Moscow, Rosstat Publ., 2012. Available at: http://www.gks.ru/wps/wcm/connect/rosstat_main/rosstat/ru/statistics/publications/catalog/doc_1139841601359 (accessed: 14.11.2013). (In Russian)

11. Saydullaev F. S. Dynamics of a small business's development in regions of Russia in 2012. Quarterly informational and analytical report. Moscow, NISIPP Publ., 2013, 35 p. Available at: http://www.nisse.ru (accessed: 14.11.2013). (In Russian)

12. Statistics of small and medium business enterprises in the Russian Federation: the key indicators, the dynamics of the SMBE-sector (2008-2011). Resource centre of small and medium business. Non-commercial Foundation. Available at: http://www.rcsme.ru/ru/library/llist/130/id (accessed: 14.11.2013). (In Russian)

13. Suglobov A. E. Boboshko V. I. Main tendencies of small business development in Russia. Regional economics: Theory and Practice. 2008, no. 19, pp. 2-11. (In Russian)

14. Philippov D. V. Methodics of evaluating the level of regional business development. State Management. Electronic bulletin. 2013, no. 36, pp. 252-262. Available at: http://www.e-journal.spa.msu.ru (accessed: 13.11.2013). (In Russian)

15. Tzarev V. V. Assesment of business' evaluation. Theory and methodology: manual for university students. Moscow, UNITY-DATA Publ., 2007, 478 p. (In Russian) 


\title{
УДК 316.3/.4
}

\section{ЭКОНОМИКА ОБЩЕСТВА ЗНАНИЯ: НАУЧНО-ОБРАЗОВАТЕЛЬНЫЕ ПРИОРИТЕТЫ РАЗВИТИЯ (обзор проблемы)}

\author{
О. А. Латуха, Е. А. Пушкарёва (Новосибирск, Россия)
}

В настоящей статье представлен обзор основных научных исследований по проблеме развития экономики общества знания с позиции научно-образовательных приоритетов. Соотносятся не только понятия информационное общество и общество знания, но и экономические факторы их развития.

Подчеркивается необходимость системного исследования указанных проблем: чем выше степень системности в решении проблем, тем эффективнее решение практических задач. Процессы научно-технического изменения привели к формированию информационного общества. Под информачионным обществом понимается такое общество, где информация превратилась в важнейший ресурс, производство и распределение которого является существенной (социально и личностно значимой) экономической, политической и культурной деятельностью. Информационная сфера является системообразующим фактором современного общества. Говоря об обществе знания, в первую очередь, подразумевается значимость научного и научно-технического знания для всех аспектов преобразования социальной жизни. Экономика, основанная на знаниях - это экономика, создающая, распространяющая и использующая знания в разнообразных формах, при этом знания обогащают все отрасли, все секторы и всех участников экономических прочессов. В рамках этой экономики знания создаются в виде научной и высокотехнологичной продукиии, высококвалифичированных услуг, образования.

Ключевые слова: общество знания, информационное общество, экономика общества знания, наука и образование, системность, экономические процессы.

Сегодня научное знание становится основой организации людей, необходимым условием их совместной деятельности. Оно во все большей степени приобретает значение интегрирующего начала в общественной жизни, приходя на смену традиционным формам объединения людей [17-18, 24, 29, 31]. Проанализируем, каким образом знание и информация в современном обществе влияют на развитие и взаимодействие образования и науки.

Латуха Ольга Александровна - кандидат экономических наук, доцент кафедры организации здравоохранения и общественного здоровья ФПКиППВ, Новосибирский государственный медицинский университет.

E-mail: latuha@mail.ru

Пушкарёва Елена Александровна - доктор философских наук, профессор кафедры права и философии, Новосибирский государственный педагогический университет.

E-mail: pushkarev73@mail.ru 
Процессы научно-технического изменения привели к формированию со второй половины XX в. так называемого информационного общества [40-41]. Информационная составляющая накладывает отпечаток на все сферы жизнедеятельности, в том числе и на сферы науки и образования [3, 20, 25, 32]. На каком основании общество называется «информационным»? - спрашивает В. И. Замышляев: «Обмен информацией между людьми осуществлялся всегда. Известны фазы информационного обмена в историческом процессе: устная, письменная, книжная, компьютерная. <..> Тотальность обработки любой информации с помощью технических средств, очевидно, и есть основание информационного общества. И широко распространенные термины “информатизация”, “компьютеризация” подтверждают зависимость содержащихся в них понятий от степени развития технических, материальных носителей информации» [10, с. 90]. Другими словами, возникновение понятия «информационное общество» связано, прежде всего, с воздействием, оказываемым современными информационными технологиями на развитие социальной организации общества. Под информационным обществом, по мнению Б. О. Майера и др. [7, 11, 23, 26, 29, 41, 43], понимается общество, в котором большинство граждан участвует в процессе создания, сбора, хранения, обработки или распределения информации.

Сама концепция информационного общества является достаточно хорошо разработанной, но продолжает наполняться новым содержанием в связи с появлением все новых черт этой цивилизации. Собственно началом формирования информационного общества принято считать статистический отчет, появившийся в конце 1950-х гг. в Департаменте коммерции США, свидетельствующий, что впервые в истории число служащих превысило количество производственных рабочих. Новое состояние общественного развития характеризовалось как «постиндустриальное» (Д. Белл), «технологическое» (Дж. П. Грант), «программируемое» (А. Турен), «постбуржуазное» (Дж. Литхайм), «постпотребительское» (Д. Рисмен), «третьей волны», «супериндустриальное» (О. Тоффлер), «посткапиталистическое» (Р. Дарендорф) и др. В работах таких авторов как Д. Белл, О. Тоффлер, Е. Масуда, М. Кастельс, П. Драккер и др. исследователей оптимистические перспективы развития человечества связывались с признанием усиливающейся роли в современном мире теоретических знаний, информации и услуг (в широком смысле) [6, 16, 30].

Под информационным обществом понимается такое общество, где информация превратилась в важный ресурс, производство и распределение которого является существенной (социально и личностно значимой) экономической, политической и культурной деятельностью. В этом обществе информация осознается как товар, как средство управления личностью и обществом, как инструмент власти, как оружие в экономической и политической борьбе и др. [43]. Если в предшествующих видах общества основной объем капитала был сосредоточен в производстве материальных ресурсов, необходимых для жизнедеятельности человеческого сообщества, то в информационном обществе доля подобного капитала не является доминирующей, - значительная часть капитала сосредотачивается в сфере производства и распределения информации.

Информационная сфера, являясь системообразующим фактором современного общества, активно влияет на состояние политической, экономической, социокультурной сфер [1-2, 8, 18]. Некоторые ученые, по мне- 
нию А. И. Левина [23, с. 5-16], видят в этом процессе стихийную составляющую, не зависящую от деятельности, как отдельных людей, так и общества в целом, поскольку человечество может лишь в малой степени контролировать развитие информационного общества.

Проникновение практически во все сферы социальной жизни информационных технологий тесно связано с процессами глобализации. Глобализация - это проявление современной научно-технической революции, суть которого заключается в образовании органической связи науки с производством, превращении производства в широкомасштабный инновационный процесс, возникновении нового способа производства, основанного на информационных технологиях.

Будущее информационного общества многие теоретики связывают с созданием глобальной информационной системы [7, 19, 27, 35-36]. Скорее всего, ее основой станет сеть Интернет, но выглядеть она будет подругому. Основанная на распределенных принципах, по своей сути она будет логичной, иерархически организованной, централизованной и общедоступной [15]. Именно эта глобальная информационная система становится структурной основой образовательной системы. И чем выше степень системности в решении проблем, тем эффективнее решение любых практических задач [38]. Происходит слияние библиотечных фондов, архивов, научных порталов, баз данных, научно-исследовательских отчетов и другой научно-образовательной информации в единую систему.

Процессы глобализации стимулируются бурным развитием так называемой «новой экономики», основанной на достижениях информационно-технологической революции. Основатель и президент японского Института информационного общества Е. Масуда [30] использовал для характеристики наступающей эпохи термин «информационное общество», исходя из того, что на первый план общественной жизни выступает четвертый, информационный сектор экономики (вслед за сельским хозяйством, промышленностью и экономикой услуг); таким образом, информация и знания революционизируют не только сферу материального производства, но и преобразуют жизнь общества.

Характеризуя знание и информацию в приоритетах экономического развития общества, в современных исследованиях подчеркивается, что знание и информация не только стали организующим началом постиндустриального общества, но и сам характер знаний модифицировался: ключевое положение стало отводиться теоретическим знаниям, которые в виде изобретения или организационного усовершенствования вовлекаются в практическую переработку ресурсов. В практику вошло понятие «экономика знаний» [14].

Экономика, основанная на знаниях - это экономика, позволяющая превращать знания в доход, причем не только в отраслях, связанных с высокими технологиями. Характеристикой экономики, основанной на знаниях, является то, что знания стали самостоятельным мощным фактором производства, который нельзя заменить другими факторами [4, с. 12-13].

Инновации, основанные на знании, не только на новом, но уже имеющемся и не только сугубо научном или техническом, но и навеянном опытом социальной жизни общества, по словам П. Ф. Драккера, представляют собой «сверх-звезды» подлинного предпринимательства. Именно они в случае успеха приносят их инициаторам и создателям большую известность. Конечно далеко не всякая основанная на знании инновация зна- 
чима и важна для общества. Некоторые из таких инноваций на деле оказываются тщетными и бесполезными. Но в их общей массе, как подчеркивает в своем исследовании Б. П. Пряников, «попадаются не только вполне удавшиеся, но и высоко ценимые многими поколениями инновации, творящие историю» [34, с. 66]. Кроме того, основанные на знании инновации весьма специфичны и потому отличаются от других инноваций своими базовыми характеристиками [34]: длительностью периода «появление - воплощение - использование»; высокими степенью риска полного провала и ценой связанных с этим потерь; слабой предсказуемостью результата, а также теми вызовами, которые они бросают реализующим их предпринимателям.

Таким образом, как подчеркивают в своем исследовании А. Л. Гапоненко, Т. М. Орлова, экономика, основанная на знаниях, характеризуется более высоким уровнем рисков, с которыми сталкиваются субъекты этой экономики. Увеличивающийся темп изменений в современной экономике приводит к тому, что появление нового знания не только все быстрее обесценивает материальные элементы и факторы производства, но и делает бесполезными многие нематериальные факторы производства, вложения в которые могут окупиться не полностью или привести к убыткам. Риски, связанные с высоким темпом технологических и управленческих изменений, становятся таким образом выше [4, c. 13].

Согласно современным представлениям, экономику в информационном обществе правильнее называть не «информационной», а «информациональной» (М. Кастельс), т. е. такой, где знания и информация перестают быть самоценностью, а используются как технологическая база для производства зна- ния и информации более высокого уровня. В связи с этим, образование должно быть ориентировано не на трансляцию определенного количества информации, а на их практическое использование. С одной стороны, по мнению В. И. Игнатьева [11], это будет способствовать переходу от обучающей к объясняющей образовательной концепции, делающей упор не на изучение фактов, а на раскрытие причинно-следственных связей явления и нахождение общих закономерностей. С другой, - к вовлечению обучающихся в практическую деятельность на возможно более раннем этапе с применением полученных в учебном процессе знаний.

Если говорить об экономике информационного общества, то многие исследователи считают, что экономическое и политическое управление будет основано на теоретическом анализе и планировании - как в масштабах государства, так и в частных случаях (М. А. Девяткина, Т. А. Мирошникова, Ю. И. Петрова, Р. Н. Федосова и др. [4, 9, 13, $22,33])$. Образовательный процесс с неизбежностью становится более управляемым и научно регулируемым [5, 21, 24, 31, 39]. Это не значит, что государство будет непосредственно вмешиваться в дела образовательной системы. В информационном обществе централизованного государства как такового не будет существовать и общество станет сетевым. Поэтому образовательная система будет более чутко реагировать на происходящие в обществе изменения и гибко изменяться в соответствии с текущими требованиями и теоретическими прогнозами. Следует также ожидать, что традиционные педагогические теории образования будут интегрированы в более сложные теоретические комплексы. Образование станет по-настоящему научным и из практической превратится в теоретиче- 
скую сферу (В. И. Игнатьев, Ф. И. Розанов [11]).

Одной из основных ценностей информационного общества становится время, вследствие убыстрения информационных коммуникаций. Кроме того, мгновенность информационных потоков и глобализация бизнеса приводят к формированию «экономики реального времени» (М. Кастельс [15]). Необходимость мгновенного получения значимой информации и возможность быстрого доступа к тем или иным образовательным услугам способствуют распространению так называемой «системы образования реального времени». Вряд ли все образование станет развиваться по этому сценарию, но многие сферы образовательных услуг - обязательно. Человек в информационном обществе постоянно сталкивается с новой информацией, новыми технологиями, новыми условиями работы и быта. Это формирует необходимость постоянного доступа к актуальным базам данных, консультациям специалистов, возможности развить те или иные навыки и умения, необходимые в данный момент. В таких условиях образование становится не продуктом, а сервисом, т. е. главным является не то, какие знания человек получает, а то, насколько оперативно и доступно они предоставляются (В. И. Игнатьев, Ф. И. Розанов [11]). Причем система образования реального времени актуальна не только для отдельных индивидов, но и для экономики, общественных и государственных организаций и для самих научных и образовательных учреждений.

Однако дальнейшее социальное развитие показало недостаточность концепции информационного общества для описания и анализа всех происходящих в социуме изменений, и в конце 1990-х гг. получила широкое развитие концепция «общество знаний» $[1,4,12,17,28,30]$. Заместитель генерально- го директора ЮНЕСКО по вопросам коммуникации и информации Абдул Вахид Хана писал: «На самом деле эти два понятия являются взаимодополняющими. Информационное общество является функциональным блоком общества знаний. По моему мнению, концепция информационного общества связана с идеей “технологических инноваций”, тогда как понятие “общество знаний” охватывает социальные, культурные, экономические, политические и экономико-правовые аспекты преобразований, а также более плюралистический, связанный с развитием, взгляд на будущее. С моей точки зрения, концепция “общество знаний” предпочтительнее концепции "информационное общество", поскольку она лучше отражает сложность и динамизм происходящих изменений» [43].

Экономика, основанная на знаниях - это экономика, создающая, распространяющая и использующая знания в разнообразных формах, при этом знания обогащают все отрасли, все секторы и всех участников экономических процессов. В рамках этой экономики знания создаются в виде научной и высокотехнологичной продукции, высококвалифицированных услуг, образования [4, с. 12-13].

Несмотря на различия в оценках того, что считать характерным признаком современных изменений в обществе практически все исследователи выделяют тот факт, что будущее общество - это общество, где определяющим фактором развития будут информация и знания. Как пишет, Н. Штерн, «основы вырисовывающегося на горизонте общественного порядка зиждутся на знании <..> Если знание не только является конститутивной особенностью современной экономики, но и становится организующим принципом всего общества, уместно назвать такую форму жизни “обществом знания". Это означает, 
прежде всего, что на основе знания мы обустраиваем всю нашу жизнь» [42].

Говоря об обществе знания, в первую очередь, как правило, подразумевается значимость научного и научно-технического знания для всех аспектов преобразования социальной жизни $[17,38-40]$. Научное и научно-техническое знание в современном обществе (тем более, в обществе ближайшего будущего) имеет и будет иметь особый статус не только «благодаря своей абсолютной истинности, объективности, бесспорности или адекватному отображению реальности» [42], но и потому, что эта форма знания в большей мере, чем какая-либо другая, создает новые возможности действия, усваиваемые и используемые индивидами, фирмами и государствами и в целом всем обществом. Однако «наука не дает людям никаких истин - она может дать им только более или менее обоснованные гипотезы и вероятностные выводы. Вместо того чтобы быть источником достоверных знаний и уверенности, она в первую очередь является источником неуверенности и общественно-политических проблем» [42]. Именно поэтому в период перехода к обществу знания так возрастает роль всего блока гуманитарных наук, которые позволяют проанализировать и осознать социальную специфику происходящих «технотронных» изменений, предвосхитить их последствия и наметить пути нивелировки отрицательных последствий этих изменений.

В тоже время, интеграционные процессы делают необходимым развертывание актуальной институциональности науки и образования, с тем, чтобы в указанных информационных процессах и в соответствующих сферах общественной жизни, институты науки и образования были совместимыми и продуктивными, поскольку не всякое знание, которым располагает современная наука, по многим причинам (по характеру его гипотетичности и дискуссионности, по уровню доказательности на практике, по характеру верификации данных теории и т. д.) может стать достоянием образовательных процессов.

\section{СПИСОК ЛИТЕРАТУРЫ}

1. Александров И. А. Системность знаний как категорический императив научного и учебного познаний // Философия образования. - 2003. - № 2 (7). - С. 45-51.

2. Блауберг И. В., Юдин Э. Г. Становление и сущность системного подхода. - М.: Наука, 1973. - 270 c.

3. Воронина Т. Перспективы образования в информационном обществе [электронный ресурс]. - Режим доступа: http://ncdo.levsha.ru/Pub/036D.htm. (дата обращения: 15.08.14)

4. Гапоненко А. Л., Орлова Т. М. Управление знаниями. Как превратить знания в капитал. М.: Эксмо, 2008. - 400 с.

5. Герасёв А.Д., Барахтенова Л.А. Философия системного управления образованием в кризисный период: основные принципы // Философия образования. - 2009. - № 4. - С. 3-9.

6. Драккер П. Постэкономическое общество. - М., 1993. - 197 с.

7. Евзрезов Д. В., Майер Б. О. Глобализация, информационное общество и отечественное образование // Глобализация, информационное общество и отечественное образование // Философия образования. - 2008. - № 2 (23). - С. 194-201.

8. Егоров Ю. Л. Принцип системности: сущность и функции в познании. - М.: ЗелО, 1997. $175 \mathrm{c}$. 
9. Жук М.В., Наливайко Н.В., Пушкарёва Е.А. Инновационное образование как фактор развития человеческого капитала в условиях общества знаний // Философия образования. 2010. - № 2. - С. 253-271.

10. Замышляев В. И. Гуманитарные смыслы информационного общества // Философия образования. - 2005. - № 1. - С. 85-92.

11. Игнатьев В. И., Розанов Ф. И. Образование в информационную эпоху // Философия образования. - 2008. - № 2 (23). - С. 76-86.

12. Ильинский И. М. Образовательная революция. - М.: Изд-во Московской гуманитарносоциальной академии, 2002. -592 с.

13. Инновационная политика высшего учебного заведения: коллективная монография /

М. А. Девяткина, Т. А. Мирошникова, Ю. И. Петрова и др.; под ред. Р. Н. Федосовой. - М.: Экономика, 2006. - $178 \mathrm{c}$.

14. Иноземцев В. Л. Расколотая цивилизация: наличествующие предпосылки и возможные последствия постэкономической революции. - М., 1999. - С. 39-41.

15. Кастельс М. Галактика Интернет: размышления об Интернете, бизнесе и обществе. - Екатеринбург: У-Фактория, 2004. - 328 с.

16. Кастельс М. Информационная эпоха: экономика, общество и культура. - М.: ГУ ВШЭ, 2000. $-458 \mathrm{c}$.

17. Князев Н. А. Наука, философия и образование в аспекте диалектизации знания // Философия образования. - 2004. - № 9. - С. 258-264.

18. Князев Н. А. Философские проблемы сущности и существования науки: монография. Красноярск: Сиб. гос. аэрокосм Ун-т, 2008. - 270 с.

19. Костюк В. Н. Информация как социальный и экономический ресурс. - М.: Магистр, 1997. $48 \mathrm{c}$.

20. Кузьмин В. П. Системный подход в современном научном познании // Вопросы философии. - 1980. - № 1. - С. 62-68.

21. Латуха О. А., Пушкарёв Ю. В. Роль высших учебных заведений в создании инноваций // Вестник Новосибирского государственного педагогического университета. - 2013. - № 3. C. $66-72$.

22. Латуха О.А., Пушкарёв Ю. В. Экономическое развитие современного общества и проблема подготовки инновационных кадров // Вестник Новосибирского государственного педагогического университета. - 2012. - № 5. - С. 50-56.

23. Левин А. И. Устойчивое развитие и информационное общество: тенденции, проблемы противоречия // Философские науки. - 2004. - № 9. - С. 5-16.

24. Леднев В. С. Научное образование. - М.: МГАУ, 2002. - 120 с.

25. Леонов А. М. Наука о сложности в эпоху постмодерна: монография. - Якутск: Изд-во Якутского ун-та, 2004. - 560 с.

26. Майер Б. О. Когнитивные аспекты современной философии отечественного образования: монография / отв. ред. Н. В. Наливайко. - Новосибирск: Изд-во СО РАН, 2006. - 276 с.

27. Майер Б. О. Технологическая платформа «Образование»: онтологический анализ // Вестник Новосибирского государственного педагогического университета. - 2012. - № 2(6). C. $36-47$.

28. Майер Б.О., Евзрезов Д. В. Изменения в системе современного общества и реформы высшего образования // Вестник Новосибирского государственного педагогического университета. -2012.-№ 6.-С. 37-44. 


5(21)2014 www.vestnik.nspu.ru ISSN 2226-3365

29. Масуда Е. Информационное общество как постиндустриальное общество. - М., 1997. 587 с.

30. Москаленко А. Т. Динамика знаний и образования в условиях научно-технической революции // Философия образования. - 2002. - № 5. - С. 75-79.

31. Наука в России: современное состояние и стратегия возрождения. Серия «Научные доклады» / Отв. ред. Е. В. Семенов, Н. Н. Семенова, А. В. Юревич. - Вып. 2. - М.: Логос, 2004. $384 \mathrm{c}$.

32. Нейматов Я. М. Образование в ХХІ веке: тенденции и прогнозы. - М.: Алгоритм, 2002. $480 \mathrm{c}$.

33. Некипелов А. Экономическая политика: стратегия и тактика. Интеграция высшего образования и науки // Проблемы теории и практики управления. - 2006. - № 6. - С. 8-19.

34. Пряников Б. П. Методология теорий производительности труда и капитала: ретроспектива нового времени и перспектива экономики знания: монография. - Челябинск: Изд-во ЮУрГУ, $2006-224$ с.

35. Пушкарёв Ю. В., Пушкарёва Е. А. Развитие образования в условиях новой системы ценностей глобального общества // Вестник Новосибирского государственного педагогического университета. - 2012. - № 4. - С. 20-25.

36. Садовничий В. А. Знание и мудрость в глобализирующемся мире // Философия образования. - 2005. - № 2 (13). - С. 3-9.

37. Сандакова Л. Б., Бажутина Т. О. Культура понимания в современной философии образования // Философия образования. - 2007. - № 2 (19). - С. 230-237.

38. Сычева Л. С. Современные процессы формирования наук: опыт эмпирического исследования. - Новосибирск, 1984. - 160 с.

39. Титова В. А., Латуха О. А. Современные аспекты управления инновационной деятельностью высшего учебного заведения // Менеджмент в России и за рубежом. - 2007. - № 6. C. 42-52.

40. Урсул А. Д. Проблема информации в современной науке. - М.: Наука, 1975. - 386 с.

41. Уэбстер Ф. Теории информационного общества / пер. с англ. М. В. Арапова, Н. В. Малыхиной; под ред. Е. Л. Вартановой. - М.: Аспект Пресс, 2004. - 400 с.

42. Штерн Н. Мир из знания. 2001 [электронный ресурс]. - Режим доступа: http: //filosof.historic.ru/books/item/f00/s00/z0000958/st000.shtml (дата обращения: 15.08.14)

43. The Information Society / the Knowledge Society [electronic resource] http: //www.vecam.org (available at: 15.08.14)

44. Drucker P. F. Innovation and Entrepreneurship: Practice and Principles. 1-st Harper Business ed. N.Y.: Harper Business Publ. Inc., 1993. 293 p.

45. Drucker P. F. Post-capitalist Society. N.Y.: Harper Business Publ. Inc., 1993.

46. Castells M. The Internet Galaxy. Reflections on the Internet, Business and Society. Oxford UP. 2001. $304 \mathrm{p}$.

47. Castells M. The Rise of the Network Society, With a New Preface: vol. I: The Information Age: Economy, Society, and Culture. Oxford, 1997. 461 p.

48. Castells M. The Power of Identity, vol. II of The Information Age: Economy, Society and Culture. Oxford, 2010. 584 p.

49. Masuda Y. The Information Society: as Post-Industrial Society. World Future Society, Washington, D.C., U.S.A., 1981.

50. Webster F. Theories of the Information Society. Second Edition. L.: Routledge, 2002. 
DOI: $10.15293 / 2226-3365.1405 .11$

Latuha Olga Aleksandrovna, Candidate of Economics Sciences, Associate Professor of Faculty of the Organization of Public Health Services and Public Health, Novosibirsk State Medical University. Novosibirsk, Russian Federation.

E-mail: latucha@mail.ru

Pushkareva Elena Aleksandrovna, Doctor of Philosophical Sciences, Professor of Faculty of Philosophy, Novosibirsk State Pedagogical University, Novosibirsk, Russian Federation.

E-mail: pushkarev73@mail.ru

\title{
BUSINESS KNOWLEDGE SOCIETY: SCIENTIFIC AND EDUCATIONAL DEVELOPMENT PRIORITIES (overview of the problem)
}

\begin{abstract}
This article presents an overview of the basic research on the problem of economic development of the knowledge society from the perspective of research and educational priorities. Relate not only to the concept of the information society and knowledge society, but also economic factors of their development.

Emphasizes the need for systematic study of these problems: the higher the degree of regularity in the solution of problems, the better the solution of practical problems. Processes of scientific and technological changes have resulted in the information society. The Information Society is understood to mean a society where information has become the most important resource, production and distribution of which is essential (socially and personally meaningful) economic, political and cultural activities. Information sphere, being a factor which modern society. Speaking of the knowledge society, first of all, means the significance of scientific and technical knowledge for all aspects of the transformation of social life. Economy based on knowledge - it's the economy, creating, distributing and using knowledge in a variety of forms, with the knowledge enriches all industries, all sectors and all participants in economic processes. As part of the knowledge economy are created in the form of scientific and high-tech products, high-quality services, and education.
\end{abstract}

Keywords

knowledge society, information society, the economy of the knowledge society, science and education, systemic, economic processes

\section{REFERENCES}

1. Alexandrov I. A. System knowledge as a categorical imperative of scientific and educational knowledge. Philosophy of Education. 2003, no. 2 (7), pp. 45-51. (In Russian)

2. Blauberg I. V., Yudin E. G. Formation and the essence of a systematic approach. Moscow, Nauka Publ., 1973, 270 p. (In Russian) 
3. Voronina T. Perspectives on Education in the information society. Accessed: http://ncdo.levsha.ru/Pub/036D.htm. (available at: 15.08.14)

4. Gaponenko A. L., Orlova T. M. Knowledge Management. How to turn knowledge into capital. Moscow, Eksmo Publ., 2008, 400 p. (In Russian)

5. Gerasyov A. D., Barakhtenova L. A. Philosophy of system management of education during the crisis period: main principles. Philosophy of education, 2009, no. 4, pp. 3-9. (In Russian)

6. Drucker P. Posteconomic Society. Moscow, 1993, 197 p. (In Russian)

7. Evzrezov D., Mayer B. O. Globalization, Information Society and domestic education. Philosophy of Education. 2008, no. 2 (23), pp. 194-201. (In Russian)

8. Egorov Yu. L. Systems principle: the nature and function in the knowledge. Moscow, Exceedingly Publ., 1997, 175 p. (In Russian)

9. Ghuk M.V, Nalivaiko N.V., Pushkareva E. A. Innovative education as a factor in the development of human capital in a knowledge society. Philosophy of Education. 2010. no. 2. pp. 253-271.

10. Zamyshlyaev V. I. Humanities meanings Information Society. Philosophy of Education. 2005, no. 1, pp. 85-92 (In Russian)

11. Ignatiev V. I., Rozanov F. Education in the information age. Philosophy education. 2008, no. 2 (23), pp. 76-86. (In Russian)

12. Il'inskii I. M. Educational Revolution. Moscow, Moscow Humanitarian-Social Academy Publ., 2002, 592 p. (In Russian)

13. Innovation policy institution of higher education: a collective monograph. M. A. De Vyatkina, T. A. Miroshnikov, Y. I. Petrova et al .; (ed.) R. N. Fedosova. Moscow, Economy Publ., 2006, 178 p. (In Russian)

14. Inozemtsev V. L. Broken Civilization: Preexisting conditions and opportunities in post-economic consequences of the revolution. Moscow, 1999, pp. 39-41. (In Russian)

15. Castells M. Internet Galaxy: Reflections on the Internet, business and society. Yekaterinburg, U-Factoria Publ., 2004. (In Russian)

16. Castells M. The Information Age: Economy, Society and Culture. Moscow, HSE Publ., 2000, 468 p. (In Russian)

17. Knyazev N. A. Science, philosophy and education in terms of knowledge dialectic. Philosophy of Education. 2004, no. 9, pp. 258-264. (In Russian)

18. Knyazev N. A. Philosophical problems of essence and existence sciences. Monograph. Krasnoyarsk, Siberian State Aerocosmic University Publ., 2008, 270 p. (In Russian)

19. Kostyuk V. N. Information as a social and economic resource. Moscow, Magistr Publ., 1997, 48 p. (In Russian)

20. Kuzmin V. P. System approach in modern scientific knowledge. Problems of philosophy. 1980, no. 1, pp. 62-68. (In Russian)

21. Latuha O.A., PushkarevYu.V. Role of higher educational institutions in creation of innovations. Novosibirsk State Pedagogical University Bulletin, 2013, no. 3 (13), pp. 66-72. (In Russian)

22. Latuha O. A., Pushkarev Y. V. Economic development of modern society and the problem of innovation staff training. Novosibirsk State Pedagogical University Bulletin, 2012, no. 5, pp. 50-56. (In Russian)

23. Levin A. I. Sustainable development and the information society: trends, challenges protoinsufficiencies. Philosophical sciences, 2004, no. 9, pp. 5-16. (In Russian)

24. Lednev B. C. Science education. Moscow, 2002, 120 p.

25. Leonov A. M. Science of complexity in the postmodern era. Monograph. Yakutsk, , Yakutsk University Publ., 2004, 560 p. (In Russian) 
26. Mayer B. O. Cognitive aspects of contemporary philosophy of national education. Monographs. Novosibirsk, Siberian Branch of the Russian Academy of Sciences Publ., 2006, 276 p. (In Russian)

27. Mayer B. O. Technology Platform "Education”: ontological analysis. Novosibirsk State Pedagogical University Bulletin, 2012, no. 2 (6), pp. 36-47 (In Russian)

28. Mayer B.O., Evzrezov D. V. Changes in system of the modern society and reform of higher education. Novosibirsk State Pedagogical University Bulletin, 2012, no. 6 (10), pp. 37-44. (In Russian)

29. Masuda E. Information society as post-industrial society. Moscow, 2006, 587 p. (In Russian)

30. Moskalenko A. T. Dynamics of knowledge and education in the scientific and technological revolution. Philosophy of Education, 2002, no. 5, pp. 75-79. (In Russian)

31. Science in Russia: current status and strategy for recovery. Series "Research reports". (Ed.) E. V. Semenov, N. N. Semenov, A. V. Jurevich. Moscow, Logos Publ., 2004, 384 p. (In Russian)

32. Neimatov Y. M. Education in the XXI Century: Trends and Forecasts. Moscow, Algo-rhythm Publ., 2002, 480 p. (In Russian)

33. Nekipelov A. Economic policy: strategy and tactics. Integration of higher education, and science. Problems of the theory and practice of management. 2006, no. 6, pp. 8-19. (In Russian)

34. Pryanikov B. P. Methodology theories of labor and capital: a retrospective of the new time and the prospect of the knowledge economy. Monograph. Chelyabinsk, SUSU Publ., 2006, 224 p. (In Russian)

35. Pushkarev Y. V., Pushkareva E. A. Development of education in the new system of values of global society. Novosibirsk State Pedagogical University Bulletin, 2012, no. 4, pp. 20-25. (In Russian)

36. Sadovnichiy V. A. Knowledge and Wisdom in a globalizing world. Philosophy of Education, 2005, no. 2 (13), pp. 3-9. (In Russian)

37. Sandakova L. B., Bazhutin T. S. Culture of understanding in contemporary philosophy of education. Philosophy of Education, 2007, no. 2 (19), pp. 230-237.

38. Sycheva L. S. Modern processes of formation of Sciences: the experience of empirical research. Novosibirsk, 1984, 160 p. (In Russian)

39. Titova V. A., Latuha O. A. Modern aspects of innovation governance of higher education institutions. Management in Russia and abroad, 2007, no. 6, pp. 42-52. (In Russian)

40. Ursul A. D. The problem of information in modern science. Moscow, Nauka Publ., 1975, 386 p. (In Russian)

41. Webster F. Theories of the Information Society. (Ed.) M. V. Arapova, N. V. Malykhina, E. L. Vartanova. Moscow, Aspect Press Publ., 2004, 400 p. (In Russian)

42. Stern N. The World of Knowledge. 2001. Accessed: http: //filosof.historic.ru/books/item/f00/s00/z0000958/st000.shtml) (Available at: 15.08.14)

43. The Information Society. The Knowledge Society. Accessed: http: //vecam.org (Available at: 15.08.14)

44. Drucker P. F. Innovation and Entrepreneurship: Practice and Principles. 1-st Harper Business ed., N.Y., Harper Business Publ., 1993. 293 p.

45. Drucker P. F. Post-capitalist Society. N.Y., Harper Business Publ., 1993.

46. Castells M. The Internet Galaxy. Reflections on the Internet, Business and Society. Oxford UP, 2001. 304 p.

47. Castells M. The Rise of the Network Society, With a New Preface. Vol. I: The Information Age: Economy, Society, and Culture. Oxford, 1997. 461 p. 
48. Castells M. The Power of Identity. Vol. II of The Information Age: Economy, Society and Culture. Oxford, 1997. $584 \mathrm{p}$.

49. Masuda Y. The Information Society: as Post-Industrial Society. World Future Society. Washington, D.C., U.S.A., 1981.

50. Webster F. Theories of the Information Society. Second Edition. L., Routledge, 2002. 




www.vestnik.nspu.ru

\section{БИОЛОГИЧЕСКИЕ, ХИМИЧЕСКИЕ, МЕДИЦИНСКИЕ НАУКИ}




\title{
АКТУАЛЬНОСТЬ ПОИСКА НОВЫХ МЕТОДИК ОТБОРА КУРСАНТОВ В СЛУЖЕБНО-ПРИКЛАДНЫЕ ВИДЫ СПОРТА
}

\author{
Р. Р. Халфина, М. Н. Кислицын, А. З. Минуллин (Уфа, Россия)
}

В данной статье представлены результаты предварительного спортивного отбора курсантов второго курса для участия в соревнованиях по преодолению полосы препятствий со стрельбой. На итоговый результат прохождения полосы препятствий имеет большое влияние качество стрельбы, на этом основании курсанты были подразделены на две подгруппы. Определено, что морфофункииональные показатели курсантов соответствуют возрастным нормам и не имеют достоверно значимых межгрупповых различий. Установлено, что результаты, показанные курсантами на на финише полосы препятствий, до стрелкового рубежа не имеют статистически значимых различий. По итогам контрольных тестирований физической подготовленности, установлено, что достоверно значимые различия выявлены только в проявлениях скоростно-силовых качеств, в показателях координачионных качеств достоверно значимых различий нет, хотя согласно ряду авторов именно координация влияет на итоговый результат. Поиск новых методов спортивного отбора в служебно-прикладные виды спорта является нашей первостепенной задачей.

Ключевые слова: курсанты, полоса препятствий, стрельба, физическая подготовленность, спортивный отбор.

На сегодняшний день система подготовки кадров МВД России является одной из крупнейших среди отраслевых министерств. Деятельность по подготовке профессиональных кадров для МВД осуществляется в трех ведомственных университетах, пяти академи- ях, 15 институтах, 19 филиалах вузов и шести суворовских военных училищах. В образовательных учреждениях МВД обучаются свыше 80 тыс. курсантов, слушателей, воспитанников (Барчуков И.С., 2001; Попов А.Г., 2009 $[2,8])$.

Халфина Регина Робертовна - кандидат биологических наук, старший преподаватель кафедры охраны здоровья и безопасности жизнедеятельности, Башкирский государственный педагогический университет им. М. Акмуллы.

E-mail: riga23@mail.ru

Кислицын Максим Николаевич - старший преподаватель кафедры физической подготовки, Уфимский юридический институт МВД России.

E-mail: grr233@yandex.ru

Минуллин Александр Зуфарович - начальник кафедры физической подготовки, Уфимский юридический институт МВД России.

E-mail: aminullin@mail.ru 
Ежегодно проводится спартакиада среди образовательных учреждений. В том числе и по преодолению полосы препятствий со стрельбой. На данный момент в чемпионат России по полосе препятствий со стрельбой принимают участие 15 ВУЗов России и более 70 участников

Согласно Р. А. Зубрилову [5] служебный биатлон и преодоление полосы препятствий со стрельбой являются относительно молодыми и наиболее популярными видами служебно-прикладного спорта среди силовых структур. Их появление и развитие обусловлено необходимостью постоянного совершенствования профессиональных психофизических качеств, умений и навыков, которые необходимы для успешного выполнения оперативно-служебных и служебно-боевых задач.

Таким образом, установлено, что развитие спортивно-прикладных видов спорта приобретает широкие масштабы. Многие из данных видов имеют статус - международных соревнований. И, соответственно, для достижения высоких спортивных результатов необходим более детальный отбор спортсменов.

\section{Методы и организация исследования}

В исследованиях приняли участие курсанты второго курса Уфимского юридического института МВД России $(n=158)$. Курсанты были поделены на две группы - контрольная (КГ) и экспериментальная (ЭГ). Группы комплектовались по итогам контрольного забега полосы препятствий со стрельбой. В экспериментальную группу вошли курсанты, имевшие два и менее промаха при выполнении стрельбы. В контрольную группу вошли курсанты, совершившие более двух промахов при выполнении стрельбы. Для определения силовых качеств использовался тест «подтягивание», засчитывалось максимальное количество раз. Для определения координационных качеств тест - «Бум» - пробег по бревну на время (сек) и поза Ромберга - положение стоя со сдвинутыми ногами, с закрытыми глазами и вытянутыми вперёд руками (сек). Также учитывались рост, вес, жизненная емкость легких (ЖЕЛ).

Таблица 1.

Морфофункииональные показатели курсантов второго курса УЮИ МВД России

\begin{tabular}{|c|c|c|c|c|}
\hline Показатель & $\begin{array}{c}\text { Общегрупповые } \\
\text { значения }\end{array}$ & ЭГ & КГ & $\begin{array}{c}\text { Достоверность } \\
\text { различий }\end{array}$ \\
\hline Возраст, лет & $19,19 \pm 0,46$ & $19,19 \pm 0,11$ & $19,15 \pm 0,08$ & $>0,05$ \\
\hline Рост, см & $178,36 \pm 4,93$ & $179,6 \pm 0,03$ & $177,238 \pm 0,69$ & $>0,05$ \\
\hline Вес, кг & $69,61 \pm 4,54$ & $70,2 \pm 1,12$ & $69,31 \pm 0,77$ & $>0,05$ \\
\hline ЖЕЛ, мЛ & $4580,43 \pm 558,92$ & $4348 \pm 126,01$ & $4430 \pm 76,11$ & $>0,05$ \\
\hline
\end{tabular}

Результаты исследования и их обсуждение

Средний возраст испытуемых 19,19 \pm 0,46 лет (табл. 1), весоростовые показатели соответствуют возрастным нормам и не противоречат данным полученным другими авторами (Р. У. Гуттаров и соавт. [10]). 
Полученные данные свидетельствуют об однородности группы. Соответственно, данное обстоятельство позволяет нам прове- сти сравнительный эксперимент в данной группе исследуемого контингента (рис.).

Рисунок.

Показатели спортивной результативности контрольной и экспериментальной групп

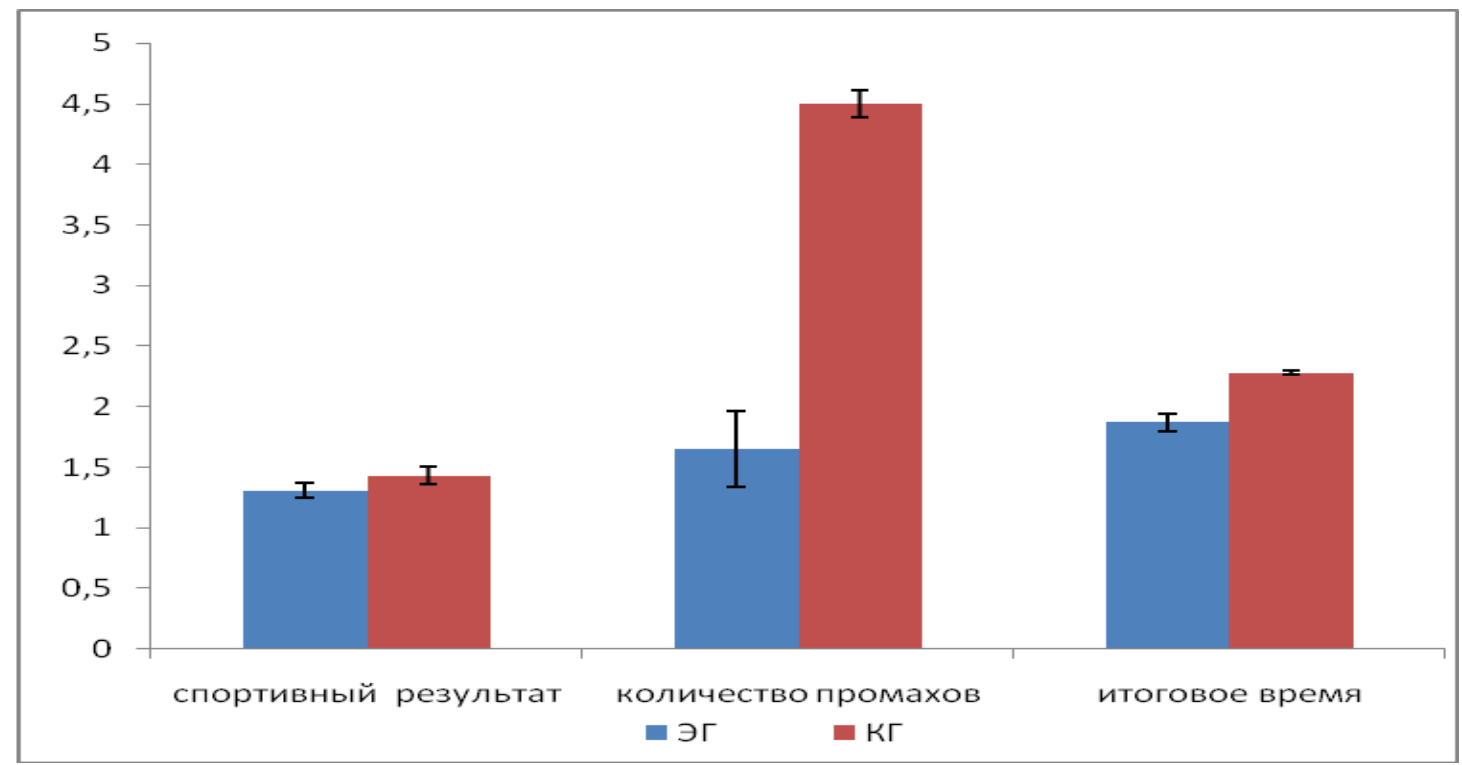

Как видно из рисунка среднее значение количества промахов имеет статистически достоверные различия ( $p<0,01)$, основываясь на данных о количестве промахов, курсанты были поделены на подгруппы. Средние значения спортивного результата (время на выходе с полосы препятствий до стрелкового рубежа) не имеет статистически значимых межгрупповых различий, что подтверждают данные об одинаковом уровне физической подготовленности курсантов контрольной и экспериментальной групп.

В таблице 2 представлены результаты контрольных тестирований, отражающих уровень развития физических качеств. Как видно из полученных результатов наблюдаются статистически значимые различия по скоростно-силовым и силовым показателям. В проявлении координационных качеств достоверных различий не выявлено.
Несмотря на более высокий уровень скоростно-силовых качеств у курсантов экспериментальной группы, данные, зафиксированные на выходе с полосы препятствий, не имеющие статистически значимых различий, показывают, что уровень развития скоростносиловых качеств не влияет на конечный результат.

Специфической особенностью преодоления полосы препятствий со стрельбой является комплексное сочетание в одном соревновании различных по физиологической направленности и воздействию на организм физической и психологической нагрузки кроссового бега или преодоление препятствий, умелого обращения и применения табельного оружия. (Клаус Ницше, 1998; Скорохватова Г.В., $2000[3,9])$ 
Вестник Новосибирского государственного педагогического университета

5(21)2014 www.vestnik.nspu.ru

ISSN 2226-3365

Таблица 2.

Показатели физической подготовленности курсантов второго курса УЮИ МВД России

\begin{tabular}{|c|c|c|c|c|}
\hline $\begin{array}{c}\text { Контрольное } \\
\text { упражнение }\end{array}$ & $\begin{array}{c}\text { Общегрупповые } \\
\text { значения }\end{array}$ & ЭГ & КГ & $\begin{array}{c}\text { Достоверность } \\
\text { различий }\end{array}$ \\
\hline $\begin{array}{c}\text { Прыжок в длину с ме- } \\
\text { ста, см }\end{array}$ & $2,34 \pm 0,15$ & $2,46 \pm 0,03$ & $2,34 \pm 0,02$ & $<0,01$ \\
\hline $\begin{array}{c}\text { Подтягивания, кол-во } \\
\text { раз }\end{array}$ & $15,11 \pm 3,35$ & $17,3 \pm 0,76$ & $14,28 \pm 0,40$ & $<0,05$ \\
\hline «Бум», сек & $1,85 \pm 0,26$ & $1,81 \pm 0,05$ & $1,84 \pm 0,04$ & $>0,5$ \\
\hline Поза Ромберга, сек & $37,09 \pm 29,11$ & $37,65 \pm 5,03$ & $35,09 \pm 4,45$ & $>0,05$ \\
\hline
\end{tabular}

Е. В. Мурашко [7] считает, что прохождение дистанции в биатлоне (режим работы в биатлоне имеет сходство с прохождением полосы препятствий со стрельбой) требует от человека разнообразных комплексов физических качеств: с одной стороны, высочайшей специальной выносливости, а с другой - высоких двигательных координационных способностей, выражающихся в целевой точности движений.

Учитывая, что уровень развития координационных качеств у обследуемых курсантов одинаков, можно предположить, что на итоговый результат влияют другие факторы, исследование которых и стало нашей приоритетной задачей для проведения дальнейшего исследования.

Согласно рассуждениям ряда авторов (Клаус Ницше, 1998; Р. А. Зубрилов, 2010; Е. В. Мурашко, 2013 [3, 5-7]) прохождение дистанции и стрельба предъявляют свои тре- бования к работе кинестетического (мышечно-двигательного) анализатора. Итоговый спортивный результат напрямую зависит как от скорости прохождения дистанции, так и от качества стрельбы

Таким образом, установлено, что курсанты второго курса имеют достаточно высокий уровень физической подготовленности, весоростовые показатели соответствуют возрастным нормам и не противоречат данным других авторов. При разделении испытуемых на подгруппы не выявлено достоверно значимых различий в морфофункциональных показателях. В показателях развития физических качеств установлено, что в экспериментальной группе более высокие значения скоростно-силовых качеств, по другим качествам достоверно значимых различий нет. Учитывая сказанное, мы ставим нашей задачей поиск новых методов спортивного отбора в служебно-прикладные виды спорта.

\section{СПИСОК ЛИТЕРАТУРЫ}

1. Апарин В. Е., Коротков Б. Е., Корчагин Г. К., Фролова Н. В. Методы оценки физической работоспособности человека: учеб. пособие. - Воронеж: ВГТУ, 1998. - 50 с.

2. Барчуков И. С. Физическая подготовка личного состава спецподразделений. - М.: СпортАкадемПресс, 2001. - С. 172. 


5(21)2014 www.vestnik.nspu.ru ISSN 2226-3365

3. Биатлон. Спортивная деятельность - тренировки - соревнования: учебник для тренеров, инструкторов и спортсменов: [переработанная редакция] / под общим руководством К. Ницше в сотрудничестве с А. Бемом [и др.]. - Висбаден: Limpert, 1998. - 355 с.

4. Воробьёв С. А. Совершенствование межмышечной координации для развития силы и скоростно-силовых качеств в физическом воспитании студентов I курса вуза: автореф. дисс. ... канд. пед. наук. - СПб, 1997. - 14 с.

5. Зубрилов Р. А. Стрелковая подготовка биатлониста: монография. - Киев: Олимпийская литература, 2010. - 296 с.

6. Лях В. И. Основные закономерности взаимосвязей показателей, характеризующих координационные способности детей и молодёжи: попытка анализа в свете концепции Н. А. Бернштейна // Теория и практика физической культуры. - 1996. - № 11. - С. 20-25.

7. Мурашко Е. В., Дунаев К. С. Особенности дыхания биатлонистов различной квалификации во время ведения стрельбы // Ученые записки университета имени П. Ф. Лесгафта. 2013. - № 11 (105).

8. Попов А. Г. Профессионально-прикладная физическая подготовка курсантов высших военных учебных заведений на основе моделирования условий боевой деятельности: автореф. дисс. ... канд. пед. наук. Волгоград: ВГАФК, 2009. - 22 с.

9. Скорохватова Г. В. Стрелковая подготовка квалифицированных биатлонисток 16-18 лет в соревновательном периоде: дис. ... канд. пед. наук. - СПб, 2000. - 166 с.

10. Гаттаров Р. У., Исаев А. П., Ляпкало В. И., Мкртумян А. М., Черепов Е. А. Морфофункциональные показатели студентов различных групп здоровья // Вестник ЮрГУ. 2007. - № 16. - C. 54-63. 
DOI: $10.15293 / 2226-3365.1405 .12$

Halfina Regina Robertovna, Candidate of Biological Sciences, Senior Lecturer Department of Health and Safety, M. Akmulla Bashkir State Pedagogical University, Ufa, Russian Federation.

E-mail: riga23@mail.ru

Kislitsyn Maxim Nikolaevich, Senior Lecturer Department of physical Preparation, Ministry of Internal Affairs, Ufa Legal Institute of Russian Federation, Ufa, Russian Federation.

E-mail: grr233@yandex.ru

Minullin Alexandr Zufarovich, Chief of Department of Physical Preparation, Ministry of Internal Affairs, Ufa Legal Institute of Russian Federation, Ufa, Russian Federation.

E-mail: aminullin@mail.ru

\title{
RELEVANCE OF SEARCH OF NEW TECHNIQUES OF SELECTION OF CADETS IN OFFICE AND APPLIED SPORTS
}

\begin{abstract}
Results of preliminary sports selection of cadets of the II course are presented in this article for participation in competitions in obstacle course overcoming with firing. On total result of passing of an obstacle course has a great influence quality of firing, on this basis cadets were subdivided into two subgroups. It is defined that morfofunktsionalny indicators of cadets meet age standards and have no authentically significant intergroup distinctions. It is established that the results shown by cadets on the obstacle course finish, till a shooting boundary have no statistically significant distinctions. Following the results of control testings of physical readiness, it is established that authentically significant distinctions are revealed only in manifestations of high-speed and power qualities, in indicators of coordination qualities of authentically significant distinctions isn't present though according to a number of authors coordination influences total result. Search of new methods of sports selection in office and applied sports is our paramount task.
\end{abstract}

\section{Keywords}

Cadets, obstacle course, firing, physical fitness, sports selection

\section{REFERENCES}

1. Aparin V. E., Korotkov B. E., Korchagin G. K., Frolova N. V. Methods of an assessment of physical efficiency of the person: studies. Voronezh, Voronezh State Technical University Publ., 1998, 50 p. (In Russian)

2. Barchukov I. S. Bodily preparation of staff of special forces. Moscow, Sportakadempress Publ., 2001, p. 172. (In Russian)

3. Biathlon. Sports activity - trainings - competitions: the textbook for trainers, instructors and athletes. The processed edition. The general guide of Claus Nietzsche in cooperation with Axel Bem [etc.]. Wiesbaden, Limpert Publ., 1998, 355 p. (In Russian)

4. Vorobyyov S. A. Improvement of intermuscular coordination for development of force and highspeed and power qualities in physical training of students of the 1 course of higher education institution. Saint Petersburg, 1997, 14 p. (In Russian) 
5. Zubrilov R. A. Shooting training of the biathlonist. Monograph. Kiev, Olympic literature Publ., 2010, 296 p. (In Russian)

6. Pole V. I. The main regularities of interrelations of the indicators characterizing coordination abilities of children and youth: attempt of the analysis in the light of the concept of H. A. Bernstein. Theory and practice of physical culture. 1996, no. 11, pp. 20-25. (In Russian)

7. Murashko E. V., Dunayev K. S. Features of breath of biathlonists of various qualification during conducting firing. Scientific notes of F. Lesgaft university. 2013, no. 11 (105). (In Russian)

8. Popov A. G. Professional and applied physical training of cadets of the highest military educational institutions on the basis of modeling of conditions of fighting activity. Volgograd, Volgograd State Physical Education Academy Publ., 2009, 22 p. (In Russian)

9. Skorokhvatova G. V. Shooting training of the qualified biathlonists of 16-18 years in the competitive period. Saint Petersburg, 2000, 166 p. (In Russian)

10. Gattarov R. U., Isaev A. P., Lyapkalo V. I., Mkrtumyan A. M., Cherepov E. A. Morphological functional indicators of students of various groups of health. Bulletin of the South Ural State University. 2007, no. 16, pp. 54-63. (In Russian) 
УДК 612.1/.8 + 608.3 + 57.043

\title{
ПОВЫШЕНИЕ ПСИХО-ФУНКЦИОНАЛЬНЫХ РЕЗЕРВОВ ОРГАНИЗМА СТУДЕНТОВ ПОД ВЛИЯНИЕМ АУДИОВИЗУАЛЬНОЙ СТИМУЛЯЦИИ
}

\author{
М. С. Головин, Р. И. Айзман (Новосибирск, Россия)
}

\begin{abstract}
Целью настоящего исследования стало изучение влияния аудиовизуальной стимуляции (АВC) на психо-функииональное состояние студентов вуза. Установлено, что после 20-22 сеансов АВС у студентов наблюдалось снижение напряжения в регуляторных системах и психофизиологическом статусе. АВС способствовала повышению парасимпатических влияний, усилению автономного контура регуляции и формированию более экономичной работы сердиа в состоянии покоя и при ортостатической пробе. Курс АВС способствовал усилению адаптационного потенциала, увеличению нейрогуморальных влияний и устранению энергодефицитных состояний. После курса тренингов АВС наблюдали улучшение показателей сочиальнопсихологической адаптачии, психофизиологических параметров (принятие других, механическая память, переключение внимания, простая зрительно-моторная реакция, снижение реактивной и личностной тревожности). Тренинги АВС могут быть рекомендованы для применения в учебном проиессе, а также в сферах, связанных с состоянием повышенного нервнопсихического и физического напряжения (спорт, диспетчерская служба и т. д.), для более быстрого восстановления и улучшения функиионального состояния организма.

Ключевые слова: аудиовизуальная стимуляция, адаптационньй потенциал, вариабельность ритма сердиа, вегетативная нервная система, психофизиологические показатели, социально-психологическая адаптация, студентыл.
\end{abstract}

\section{Введение}

Разработка и внедрение современных способов восстановления и коррекции психо-функциональных состояний при различных видах деятельности, требующих напряжения систем адаптации, является важным звеном в процессе обучения в вузе. В настоящее время существует множество методов воздействия на организм человека, обеспечивающих повышение его адаптации и улучшение

Головин Михаил Сергеевич - аспирант кафедры анатомии, физиологии и безопасности жизнедеятельности, Институт естественных и социально-экономических наук, Новосибирский государственный педагогический университет.

E-mail: golovin593@mail.ru

Айзман Роман Иделевич - доктор биологических наук, профессор, заслуженный деятель науки РФ, заведующий кафедрой анатомии, физиологии и безопасности жизнедеятельности, Новосибирский государственный педагогический университет.

E-mail: aizman.roman@yandex.ru 
функционального состояния [3, 7, 13]. В настоящее время активно развиваются инструментальные методы воздействия на функциональное состояние человека, основанные на биологической обратной связи и т. д. [9, 1415]. Вместе с тем, методика аудиовизуальной стимуляции (АВС), получившая распространение на Западе, в России успешно зарекомендовала себя в основном в сфере комплексной реабилитации [10-11] и коррекции психогенных расстройств [1], в лечении зависимостей и профилактике нарушений у лиц опасного труда [5]. Однако в сфере образования, характеризующейся нервно-психическими нагрузками, исследования влияния АВС отсутствуют.

При экспресс-оценке и динамическом контроле за адаптивными возможностями организма наиболее объективным, информативным и чувствительным методом считается анализ вариабельности сердечного ритма (ВСР) [8]. Метод является современным и общепризнанным индикатором состояния напряжения систем регуляции. Таким образом, целью нашего исследования стало изучение влияния аудиовизуальной стимуляции на психофункциональные резервы организма студентов при обучении в вузе.

\section{Методы и организация исследования}

В исследовании, состоявшем из трех этапов, приняли участие 70 студентовюношей 17-23 лет разных факультетов НГПУ, обучающихся на 3-4 курсах: контрольная группа $(n=30)$ и экспериментальная $(n=40)$. Исследование проводили с января по апрель 2014 года на базе регионального ресурсного центра мониторинга и охраны здоровья участников образовательного процесса кафедры анатомии, физиологии и БЖД НГПУ в межсессионный период, не связанный со сдачей зачетов и экзаменов.
На первом этапе проводили изучение и анализ ВСР с учетом методических рекомендаций, разработанных группой российских экспертов [6]. Регистрацию ЭКГ-сигнала осуществляли с помощью аппаратнопрограммного комплекса ВНС-Микро (Нейрософт, Россия) в положении обследуемого лежа на спине (5 мин) и при переходе в положение стоя - ортостатическая проба (6 мин). Рандомизированную выборку обследуемых составили только студенты с нормотоническим преобладающим типом регуляторных систем. Студенты симпатотоники и ваготоники из анализа исключались.

Диагностику психофизиологического состояния студентов проводили с помощью компьютерной программы Р. И. Айзмана и др. «Методика комплексной оценки здоровья студентов» (2009) [2], а также с использованием компьютерного комплекса для выполнения психофизиологических и психологических тестов с регистрацией вегетативных и эмоциональных реакций НС-Психотест (Нейрософт, Россия).

На втором этапе проводили курс тренингов аудиовизуальной стимуляции (АВC), который состоял из 20-22 сеансов, выполняемых через сутки с использованием портативного аудивизуального стимулятора «NOVO PRO» (США). Использовали две программы: первая - «поддержание работоспособности», с преобладающей частотой воздействия 7-20 Гц и длительностью 30 минут, которая, согласно паспорта прибора, активирует возбудительные процессы; вторая «глубокое расслабление», с преобладающей частотой воздействия 4-12 Гц и длительностью 25 минут, вызывающая доминирование процессов торможения.

На третьем этапе после завершения курса $\mathrm{ABC}$ исследовали качественные и количественные изменения параметров вегетатив- 
Вестник Новосибирского государственного педагогического университета

5(21)2014 www.vestnik.nspu.ru ISSN 2226-3365

ной регуляции, а также оценивали эффективность воздействия $\mathrm{ABC}$ на психофизиологический статус студентов.

Полученные результаты обработаны общепринятыми методами математической статистики с использованием непараметрического критерия Вилкоксона-Манна-Уитни для независимых выборок и считались достоверными при $p \leq 0,05$.

Все участники обследования дали добровольное информированное согласие на проведение курса тренингов, которые проводили в соответствии с Хельсинкской декларацией (1964).

\section{Результаты и их обсуждение}

По результатам временного анализа сердечного ритма можно заключить, что после тренинга АВС у студентов происходило снижение влияния симпатической регуляции и ослабление влияния высших уровней управления сердечным ритмом (табл. 1). Увеличивался вклад парасимпатических влияний в регуляторные процессы и происходило усиление автономного контура регуляции. В группе контроля за аналогичный период времени снизился вклад парасимпатических влияний в процессы формирования ритма, и произошло усиление центрального контура регуляции.

Таблица 1. Вариабельность сердечного ритма студентов контрольной и экспериментальной групп

\begin{tabular}{|c|c|c|c|c|c|}
\hline \multirow[t]{2}{*}{ Запись } & \multirow[b]{2}{*}{ Показатель } & \multicolumn{2}{|c|}{ Контроль } & \multicolumn{2}{|c|}{$\mathbf{A B C}$} \\
\hline & & январь & март & январь & март \\
\hline \multirow{9}{*}{ 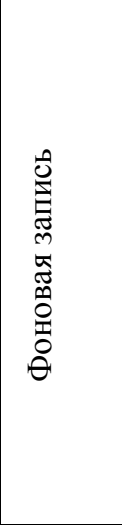 } & ЧСС, уд/мин & $59,6 \pm 1,3$ & $61,3 \pm 1,9$ & $63,2 \pm 2,5$ & $59,7 \pm 1,6$ \\
\hline & Активность автономного контура регуляции, мс & $54,1 \pm 4,4$ & $40,8 \pm 3,1^{*}$ & $53 \pm 4,7$ & $73 \pm 7,4 * \#$ \\
\hline & Мощность симпатической регуляции, мс ${ }^{2}$ & $1377 \pm 165$ & $1142 \pm 202$ & $1601 \pm 289$ & $1774 \pm 308 \#$ \\
\hline & Мощность дыхательных волн, мс ${ }^{2}$ & $1516 \pm 223$ & $967 \pm 182^{*}$ & $1329 \pm 213$ & $2297 \pm 340 * \#$ \\
\hline & Индекс централизации & $2,3 \pm 0,4$ & $3,0 \pm 0,5$ & $2,8 \pm 0,5$ & $1,9 \pm 0,4 * \#$ \\
\hline & Вариационный размах, сек & $0,33 \pm 0,01$ & $0,28 \pm 0,02 *$ & $0,32 \pm 0,02$ & $0,41 \pm 0,02 * \#$ \\
\hline & Индекс вегетативного равновесия, у. е. & $102 \pm 9$ & $152 \pm 21^{*}$ & $102 \pm 11$ & $77 \pm 10 * \#$ \\
\hline & $\begin{array}{l}\text { Показатель адекватности процессов регуля- } \\
\text { ции, у. е. }\end{array}$ & $33,2 \pm 1,7$ & $38,7 \pm 3,3^{*}$ & $34,5 \pm 3,4$ & $29,1 \pm 2,6 \#$ \\
\hline & Индекс напряжения, у. е. & $54,6 \pm 4,7$ & $75,1 \pm 11,8$ & $53,7 \pm 8,8$ & $39,4 \pm 5,8 \#$ \\
\hline \multirow{9}{*}{ 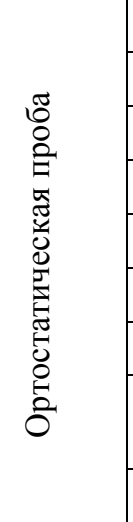 } & ЧСС уд/мин & $72,6 \pm 1,6$ & $75,8 \pm 2,3$ & $77,8 \pm 3,3$ & $73,5 \pm 2,0$ \\
\hline & Активность автономного контура регуляции, мс & $30,6 \pm 3,1$ & $23,7 \pm 2,2^{*}$ & $30 \pm 3,9$ & $41 \pm 5,8 * \#$ \\
\hline & Мощность симпатической регуляции, мс ${ }^{2}$ & $3019 \pm 294$ & $2175 \pm 215^{*}$ & $1785 \pm 182 \#$ & $2454 \pm 403$ \\
\hline & Мощность дыхательных волн, мс $^{2}$ & $516 \pm 96$ & $691 \pm 234$ & $589 \pm 153$ & $725 \pm 225$ \\
\hline & Индекс централизации & $13,1 \pm 2,0$ & $12,7 \pm 2,1$ & $7,3 \pm 1,5 \#$ & $9,1 \pm 1,6$ \\
\hline & Вариационный размах, сек & $0,35 \pm 0,01$ & $0,37 \pm 0,04$ & $0,32 \pm 0,02$ & $0,4 \pm 0,02 *$ \\
\hline & Индекс вегетативного равновесия, у. е. & $99 \pm 6,7$ & $147 \pm 18,6^{*}$ & $118 \pm 13,4$ & $83 \pm 9,3 * \#$ \\
\hline & $\begin{array}{l}\text { Показатель адекватности процессов регуля- } \\
\text { ции, у. е. }\end{array}$ & $40,5 \pm 2,4$ & $51 \pm 4,5^{*}$ & $51 \pm 4,3 \#$ & $43,9 \pm 3,5^{*}$ \\
\hline & Индекс напряжения, у. е. & $61,4 \pm 5,2$ & $89,8 \pm 14,4^{*}$ & $83,6 \pm 10,8 \#$ & $61,2 \pm 9,7^{*} \#$ \\
\hline \multicolumn{6}{|c|}{$\begin{array}{l}\text { Примечание. Достоверность внутригрупповых отличий в динамике изменений: } \\
* \mathrm{p}<0,05 \text { - внутри каждой группы в январе и марте; } \\
\# \mathrm{p}<0,05 \text { - между группами в соответствующие периоды исследования. }\end{array}$} \\
\hline
\end{tabular}


У студентов после курса АВС наблюдали также усиление суммарной активности нейрогуморальных влияний на сердечный ритм, что свидетельствует об увеличении влияния дыхательных волн на ритм сердца и формировании более экономичной его работы.

В контрольной группе существенно снижалась суммарная активность нейрогуморальных влияний и вклад дыхательных волн в формирование вариабельности ритма сердца, что можно объяснить истощением адаптационных резервов. Вместе с тем увеличивались показатели вагосимпатического баланса и индекса централизации, что свидетельствует об увеличении напряжения регуляторных систем в процессе обучения.

Таким образом, после проведения курса АВС у студентов наблюдалось снижение напряжения регуляторных систем, тогда как в группе контроля изменения носили противоположный характер. Это свидетельствует о положительном влиянии применяемой методики на состояние адаптационных процессов.

Для более точного выявления функциональных резервов важное значение имеет оценка вариабельности сердечного ритма (ВСР) при использовании функциональных проб. Ортостатическая проба является важным методом определения скрытых изменений со стороны сердечно-сосудистой системы, в частности, механизмов вегетативной регуляции и оценки состояния регуляторных систем [4].

В обеих группах при ортостатической пробе параметры, характеризующие деятельность сердечно-сосудистой системы имели такие же различия, как в состоянии покоя. В группе АВС происходило увеличение сум- марной активности нейрогуморальных влияний, тогда как в группе контроля наблюдали истощение симпатической регуляции и возникновение энергодефицитных состояний.

Курс АВС вызвал снижение централизации управления сердечным ритмом и уменьшение напряжения механизмов регуляции при ортостатической пробе. В группе контроля изменения были противоположные, характеризующие напряжение механизмов регуляции и увеличение «цены» адаптации сердечно-сосудистой системы к ортостатической нагрузке.

Исследование психофизиологического статуса после прохождения курса АВС выявило существенные изменения некоторых показателей (табл. 2). У студентов наблюдали улучшение параметров социальнопсихологической адаптации, увеличение показателя принятия других и снижение противоположного ему - неприятия других. После тренинга студенты демонстрировали более низкую личностную и реактивную тревожность, улучшение механической памяти и существенное снижение времени переключения внимания, увеличение скорости сенсомоторной реакции, повышение баланса нервных процессов возбуждения и торможения в коре головного мозга. Это может благоприятно сказаться на успеваемости и эффективности освоения учебных программ. Наряду с этим, у экспериментальной группы наблюдали увеличение жизнестойкости, характеризующей личностный потенциал студентов.

В группе контроля психофизиологические показатели оставались на уровне фоновых значений или даже имели тенденцию к снижению. 
Вестник Новосибирского государственного педагогического университета

5(21)2014 www.vestnik.nspu.ru ISSN 2226-3365

Таблица 2.

Изменение психофизиологического статуса студентов контрольной и экспериментальной групп

\begin{tabular}{|c|c|c|c|c|}
\hline \multirow[b]{2}{*}{ Показатель } & \multicolumn{2}{|c|}{ Контроль } & \multicolumn{2}{|c|}{$\mathbf{A B C}$} \\
\hline & январь & мapт & январь & мapт \\
\hline Непринятие других, баллы & $12 \pm 1,3$ & $13 \pm 1,9$ & $17 \pm 2 \#$ & $13 \pm 2 *$ \\
\hline Принятие других, баллы & $26 \pm 0,8$ & $26 \pm 0,8$ & $25 \pm 0,7$ & $29 \pm 0,8^{*} \#$ \\
\hline Личностная тревожность, баллы & $33 \pm 1$ & $34 \pm 1$ & $34 \pm 0,6$ & $31 \pm 0,8^{*} \#$ \\
\hline Реактивная тревожность, баллы & $20 \pm 1,2$ & $19 \pm 1,2$ & $22 \pm 1,5$ & $17 \pm 1,5^{*}$ \\
\hline Механическая память, баллы & $5,6 \pm 0,4$ & $5,9 \pm 0,5$ & $5,8 \pm 0,3$ & $7 \pm 0,3 * \#$ \\
\hline Переключение внимания, сек & $48 \pm 5$ & $46 \pm 5$ & $57 \pm 6$ & $42 \pm 5^{*}$ \\
\hline Простая зрительно-моторная реакция, мс & $182 \pm 4$ & $177 \pm 4,2$ & $183 \pm 3,5$ & $163 \pm 3,5^{*} \#$ \\
\hline $\begin{array}{l}\text { Реакция на движущийся объект (РДО), количество } \\
\text { совпадений }\end{array}$ & $1,3 \pm 1,7$ & $1,3 \pm 3,3$ & $1,5 \pm 0,2$ & $2,7 \pm 0,2 * \#$ \\
\hline РДО - опережения, мс & $182 \pm 13$ & $214 \pm 15^{*}$ & $173 \pm 18$ & $111 \pm 18^{*} \#$ \\
\hline РДО - запаздывания, мс & $169 \pm 26$ & $138 \pm 24$ & $149 \pm 19$ & $62 \pm 19 * \#$ \\
\hline Жизнестойкость, баллы & $131 \pm 4,5$ & $119 \pm 6^{*}$ & $122 \pm 5 \#$ & $134 \pm 5^{* \#}$ \\
\hline \multicolumn{5}{|c|}{$\begin{array}{l}\text { Примечание. Достоверность внутригрупповых отличий в динамике изменений: } \\
* \text { p }<0,05 \text { - внутри каждой группы в январе и марте; } \\
\# \mathrm{p}<0,05 \text { - между группами в соответствующие периоды исследова }\end{array}$} \\
\hline
\end{tabular}

\section{Заключение}

Результаты исследования позволяют сделать выводы:

1. Курс АВС способствовал усилению адаптационного потенциала, увеличению нейрогуморальных влияний и устранению энергодефицитных состояний, формированию более экономной работы сердца в состоянии покоя и при ортостатической пробе.

2. После курса тренингов АВС наблюдали улучшение показателей социальнопсихологической адаптации, улучшение психофизиологических параметров: повышение механической памяти, скорости переключения внимания, увеличение жизнестойкости и снижение уровня тревожности.

3. Тренинги АВС могут быть рекомендованы для применения в учебном процессе, а также в сферах, связанных с состоянием повышенного нервно-психического и физического напряжения, для более быстрого восстановления и улучшения функционального состояния организма.

Таким образом, одной из актуальных задач является разработка и внедрение в практическую деятельность специальных методов и средств, обеспечивающих стимуляцию и коррекцию систем организма. При этом они должны быть физиологически обоснованными, простыми в обращении и не давать побочных эффектов [12]. Управляя функциональными состояниями, можно существенно повысить эффективность профессиональной деятельности.

\section{СПИСОК ЛИТЕРАТУРЫ}

1. Араби Л. С., Сысоев В. Н., Кремнева Т. В. Аудиовизуальная стимуляция в комплексной терапии психогенно-обусловленных расстройств // Вестник психотерапии. - 2011. - № 39. - C. 9-17. 
2. Айзман Р. И., Айзман Н. И., Лебедев А. В., Рубанович В. Б. Методика комплексной оценки здоровья студентов. - Новосибирск, 2009. - 84 с.

3. Айзман Р. И., Айзман Н. И., Рубанович В. Б., Лебедев А. В. Принципы и алгоритмы мониторинга здоровья учащихся и студентов // Сибирское медицинское обозрение. - 2009. T. 57. - № 3. - С. 101-104.

4. Баевский Р. М., Берсенева А. П. Введение в донозологическую диагностику. - М.: Слово, 2008. - 220c.

5. Буторин Г. Г., Щеглова И. И. Преодоление симптомов посттравматического стрессового расстройства у сотрудников органов внутренних дел с применением средств аудиовизуальной стимуляции // Вестник Кемеровского государственного университета. - 2012. № 2. - С. 107-110.

6. Вариабельность сердечного ритма: стандарты измерения, интерпретации, клинического использования: доклад рабочей группы Европейского общества кардиологии и Североамериканского общества кардиостимуляции и электрофизиологии // Вестник аритмологии. 1999. - № 11. - С. 53-78.

7. Водяницкий С. Н., Диверт В. Э., Кривощеков С. Г. Внешнее дыхание и газообмен при прерывистой нормобарической гипоксии у спортсменов с различным типом тренировочного процесса // Бюллетень Сибирского отделения Российской академии медицинских наук. - 2011. - Т. 31. - № 3. - С. 33-39.

8. Кудря О. Н. Оценка функционального состояния и физической подготовленности спортсменов по показателям вариабельности сердечного ритма // Вестник Новосибирского государственного педагогического университета. - 2014. - № 1. - С. 185-195.

9. Мажирина К. Г. [и др.] Следовые эффекты игрового биоуправления: функциональное МРТ-исследование // Бюллетень экспериментальной биологии и медицины. - 2014. Т. 157. - № 3.- С. 312-316.

10. Макаров С. В. Оценка здоровья и его коррекция методами аудиовизуальной стимуляции и нейробиоуправления при наркотически зависимых состояниях. Дисс. ... канд. мед. наук. Томск, 2005. - $100 \mathrm{c}$.

11. Макаров С. В., Шубина О. С. Сравнительный анализ эффективности методов альфастимулирующего тренинга и аудиовизуальной стимуляции в комплексной программе лечения больных с героиновой зависимостью // Бюллетень Сибирского отделения Российской академии медицинских наук. - 2004. - № 3. - С. 38-44.

12. Никулин Д. И. Аудио-визуальная коррекция расстройств реакций адаптации у студентов. Дисс. ... канд. мед. наук. - М., 2011. - 115 с.

13. Сонькин В. Д., Акимов Е. Б. Беговая тренировка помогает организму справиться с анаэробными нагрузками // Теория и практика прикладных и экстремальных видов спорта. 2013. - № 2 (27). - C. 13-18.

14. Тайшин Д. О., Дружинин В. Ю., Сорокин О. В., Суботялов М. А. «Индивидуальнотипологический портрет» личности с эффективным биоуправлением длительностью сердечных сокращений // Медицина и образование в Сибири. - 2012. - № 3. - С. 1.

15. Черапкина Л. П. Изменение показателей вариабельности ритма сердца в течение курса нейробиоуправления у спортсменов разной квалификации // Бюллетень сибирской медицины. - 2013. - Т. 12. - № 2. - С. 234-241. 
DOI: $10.15293 / 2226-3365.1405 .13$

Golovin Mihail Sergeevich, Post-Graduate Student of the Department of Anatomy, Physiology and Safety of Life, Novosibirsk State Pedagogical University, Novosibirsk, Russian Federation.

E-mail: golovin593@mail.ru

Aizman Roman Idelevich, Doctor of Biological Sciences, Professor, Head of the Department of Anatomy, Physiology and Safety of Life, Novosibirsk State Pedagogical University, Novosibirsk, Russian Federation.

E-mail: roman.aizman@mail.ru

\title{
INCREASE OF PSYCHO-FUNCTIONAL RESERVES OF STUDENT'S ORGANISM UNDER INFLUENCE OF AUDIOVISUAL STIMULATION
}

\begin{abstract}
The purpose of this study was to investigate the influence of the audiovisual stimulation (AVS) on the psycho-functional state of university students.

There was found a decrease of stress in regulatory systems and psycho-physiological status of students after 20-22 sessions of AVS. AVS contributed to the increase of influence of the parasympathetic regulation and more economic heart rate, increase of parasympathetic regulation, enhance autonomic contour of regulation and a more efficient functioning of the heart at rest and during orthostatic testing. Course of AVS resulted in increase of the adaptive potential, enhanced neurohormonal influences and eliminate energy deficit states. After the training course of AVS it was observed an improvement of the socio-psychological adaptation, enhancing of psychophysiological parameters (acceptance of others, mechanical memory, speed shifting attention, a simple visual-motor reaction, decrease in reactive and personal anxiety). AVS trainings may be recommended for application in the educational process, as well as in areas related to a state of heightened neuropsychological and physical tension (sports, dispatch service, etc.), for a more rapid recovery and improve the functional state of the organism.
\end{abstract}

\section{Keywords}

audio-visual stimulation, adaptive capacity, heart rate variability, autonomic nervous system, physiological characteristics, socio-psychological adaptation, students

\section{REFERENCES}

1. Arabi L. S., Sysoev V. N., Kremneva T. V. Audio-visual stimulation in the complex therapy of psychogenic-mediated disorders. Bulletin of psychotherapy. 2011, no. 39, pp. 9-17. (In Russian)

2. Ajzman R. I., Ajzman N. I., Lebedev A. V., Rubanovich V. B. Methodology of comprehensive health assessment of students. Novosibirsk, 2009, 84 p. (In Russian)

3. Aizman R.A., Aizman N.I., Rubanovich V.B., Lebedev A.V. Principles and algorithms of students' health monitoring. Siberian medical review, 2009, vol. 57, no. 3, pp. 101-104. (In Russian)

4. Baevsky R. M., Berseneva A. P. Introduction to prenozological diagnosis. Moscow, Word Publ., 2008, 220 p. (In Russian) 
5. Butorin G. G., Shcheglova I. I. Overcoming of PTSD symptoms in police officers using audiovisual stimulation. Bulletin of the Kemerovo State University. 2012, no. 2, pp. 107-110. (In Russian)

6. Heart rate variability: standards of measurement, interpretation and clinical use: report of the working group of the European Society of Cardiology and the North American Society of cardiac pacing and Electrophysiology. Vestnik of arythmology. 1999, no. 11, pp. 53-78. (In Russian)

7. Vodyanitsky S. N., Diewert V. E., Krivoschekov S. G. External respiration and gas exchange during intermittent normobaric hypoxia in athletes with different types of training process. Bulletin of the Siberian Branch of the Russian Academy of Medical Sciences. 2011, vol. 31, no. 3, pp. 3339. (In Russian)

8. Kudrya O. N. Evaluation of functional state and physical fitness of athletes by indicators of heart rate variability. Novosibirsk State Pedagogical University Bulletin. 2014, no. 1, pp. 185-195. (In Russian)

9. Mazhirina K. G, et al. Trace the effects of biofeedback game: a functional MRI study. Bulletin of Experimental Biology and Medicine. 2014, vol. 157, no. 3, pp. 312-316. (In Russian)

10. Makarov S. V. Health assessment and its correction by methods of audiovisual stimulation and neurobiofeedback when drug addicts states. Tomsk, 2005, 100 p. (In Russian)

11. Makarov S. V., Shubina O. S. Comparative analysis of methods for alpha-stimulating training and audiovisual stimulation in the integrated program of treatment of patients with heroin dependence. Bulletin of the Siberian Branch of the Russian Academy of Medical Sciences. 2004, no. 3, pp. 38-44. (In Russian)

12. Nikulin D. I. Audio-visual correction of disorders of adaptive reactions in students. Moscow, 2011, 115 p. (In Russian)

13. Son'kin V. D., Akimov E. B. Treadmill exercise helps the body to cope with anaerobic loads. Theory and Practice of Applied and extreme sports. 2013, no. 2 (27), pp. 13-18. (In Russian)

14. Tayshin D. O., Druzhinyn V. Y., Sorokin O. V., Subotyalov M. A. "Individually-typological portrait" of personality with an effective duration of heart rate biofeedback. Health and Education in Siberia. 2012, no. 3, pp. 1. (In Russian)

15. Cherapkina L. P. Change of heart rate variability during the course of neurobiofeedback in athletes with different skills. Bulletin of Siberian Medicine. 2013, vol. 12, no. 2, pp. 234-241. (In Russian) 


\title{
УДК 616.13-004.6 + 616.153.915
}

\section{ПРОЯВЛЕНИЯ МЕТАБОЛИЧЕСКОГО СИНДРОМА У БОЛЬНЫХ МУЛЬТИФОКАЛЬНЫМ АТЕРОСКЛЕРОЗОМ}

\author{
3. Р. Хайбуллина, И. В. Косникова (Ташкент, Узбекистан)
}

Статья посвящена изучению компонентов метаболического синдрома у больных мультифокальным атеросклерозом (МФА). Анализируются изменения показателей липидного и углеводного обмена, а также маркеров системного воспаления и окислительного стресса у пациентов с МФА при атеросклеротическом проиессе в различных артериальных бассейнах (каротидном, коронарном, в магистральных артериях нижних конечностей) и их сочетаниях. Материальл и методы исследования включали в себя анализ клинико-лабораторных данных у 84 пациентов с периферическим и мультифокальным атеросклерозом. Установлено, что при периферическом атеросклерозе из компонентов метаболического синдрома (MC) наиболее часто встречается гипертриглицеридемия без ожирения; при МФА с вовлечением артерий каротидного бассейна - артериальная гипертензия и гипертриглицеридемия, при МФА со стенозом/окклюзией коронарных и каротидных артерий без поражения магистральных сосудов нижних конечностей - артериальная гипертензия, ожирение и гиперхолестеринемия. У паџиентов МФА с поражением трех артериальных бассейнов имело место наличие полного кластера МС в $60 \%$ случаев, тогда как у больных с атеросклерозом магистральных артерий нижних конечностей (АМНК), т. е. при поражении артерий одного бассейна, полный кластер МС наблюдался в $30 \%$ случаев, что наполовину меньше, чем при МФА. Это указывает на высокую значимость неблагоприятного влияния проявлений МС на развитие МФА. МФА с поражением сонньх и коронарных артерий сопровождается высоким уровнем окислительного стресса, вероятно, за счет повыленной чувствительности мозговых и сердечных тканей к гипоксии, уязвимости от токсических эффектов активных форм кислорода. У больных МФА с поражением коронарньх и сонных артерий окислительный стресс был тесно связан с воспалением: связь СРБ/МДА была прямой сильной (r = 82, $p>0,05)$. Для МФА с поражением коронарных артерий характерным стало превалирование окислительного стресса, а при АМНК было более выражено воспаление. Провоспалительный и прооксидантный статус являются факторами развития и прогрессирования МФА.

Ключевые слова: мультифокальный атеросклероз, атеросклероз магистральных артерий нижних конечностей, метаболический синдром, окислительный стресс, гипертриглицеридемия.

Хайбуллина Зарина Руслановна - доктор медицинских наук, руководитель отделения биохимии с группой микробиологии, Республиканский специализированный центр хирургии им. академика В. Вахидова.

E-mail: zr-khaybullina@rambler.ru

Косникова Ирина Викторовна - кандидат биологических наук, старший научный сотрудник, отделение биохимии с группой микробиологии, Республиканский специализированный центр хирургии им. академика В. Вахидова. 
В основе большинства болезней системы кровообращения лежит атеросклероз, который в течение многих лет протекает бессимптомно и, как правило, достаточно выражен к моменту проявления клинической симптоматики [1]. Одной из основных характеристик атеросклероза выступает мультифокальность поражения с одновременным вовлечением артерий одного или нескольких сосудистых бассейнов. Сочетанные формы атеросклероза с поражением коронарных, сонных и периферических артерий установлены в 30-65 \% случаев [2]. Окклюзии/стенозы аорты и подвздошных артерий по сравнению с другими поражениями артерий нижних конечностей составляет 4,7-12 \% и даже $30 \%$, а по данным секционных наблюдений, они занимают второе место после коронарных [3].

Морфологический субстрат поражения при мультифокальном атеросклерозе (МФА) атеросклеротическая бляшка, степень ее стабильности и эволюция во многом определяются интенсивностью системного воспаления и влиянием таких неблагоприятных факторов риска как артериальная гипертензия, дислипидемия, нарушение толерантности к глюкозе и инсулинорезистентность, абдоминальное ожирение [4].

В связи с этим актуально изучение компонентов метаболического синдрома и маркеров провоспалительного состояния у больных МФА.

\section{Цель данного исследования:}

оценка взаимосвязи между маркерами воспаления и основными составляющими метаболического синдрома у больных периферическим и мультифокальным атеросклерозом.

\section{Материалы и методы исследований.}

В исследовании приняли участие 84 мужчины с атеросклерозом магистральных артерий нижних конечностей (АМНК) и МФА в возрасте 60,2 $\pm 1,4$ лет. Все больные были госпитализированы в клинику Республиканского специализированного центра хирургии им. академика В. Вахидова (далее - РСЦХ им. ак. В. Вахидова).

Тип поражения при АМНК, характеризующийся симптомокомплексом хронической ишемии нижних конечностей, устанавливали на основании клинико-анамнестических данных, результатов допплерографии сосудов и мультисканной компьютерной томографии ангиографии артерий нижних конечностей. Для определения стеноза/окклюзии артерий каротидного бассейна, брюшной аорты пациентам проводилась МСКТ ангиография, по показаниям проводилась коронаровентрикулография.

Все больные были разделены на пять групп. Первую группу составили больные с АМНК, $n=30$; вторую группу - АМНК и атеросклерозом сонных артерий (АМНК + ACCA), $n=24$; третью группу - АМНК и атеросклерозом коронарных артерий (АМНК + АСКА), $n=12$; четвертую группу - с сочетанным поражением сонных и коронарных артерий (ACСА + ACКА), $n=8$; пятую группу больные с поражением трех артериальных бассейнов (АМНК + АССА + АСКА), $n=10$. Липидный спектр крови (общий холестерин $\mathrm{XC}$, триглицериды - ТГ, содержание глюкозы (ГЛЮ), С-реактивного белка (СРБ) определяли на автоматическом биохимическом анализаторе «Vitros 350» фирмы «Ortho Clinical Diagnostics» (Германия). Концентрацию малонового диальдегида (МДА) определяли колориметрическим методом по реакции с тиобарбитуровой кислотой (M. Michara). Диагноз MC (кластер абдоминального ожирения, гипертензии, дислипидемии и инсулинорезистентности) устанавливали на основании критериев JIS (2009) с учетом индекса массы тела (ИМТ) [5]. 


\section{Полученные результаты и их обсужде-} нuе.

На основании клинико-инструментальных методов обследования периферический атеросклероз - АМНК был диагностирован у 30 (36 \%), мультифокальный атеросклероз с поражением сосудов двух артериальных бассейнов - у 44 (52\%), поражение сосудов трех артериальных бассейнов - у 10 (12\%).

При этом сочетание АМНК с поражением артерий каротидного бассейна выявлено у 24 (27\%), сочетание АМНК с поражением коронарных сосудов - у 12 (14 \%) пациентов; сочетание стеноза/окклюзии сонных и коронарных артерий - у 8 (9 \%) пациентов. У 24 больных выявлена 2Б степень хронической ишемии, у 27 - III, у 23 - IY степень ишемии нижних конечностей. Этиологией хронической ишемии нижних конечностей во всех 100 \% случаев был атеросклероз.

Из сопутствующих заболеваний у обследованных нами больных $(n=84)$ были выявлены: ишемическая болезнь сердца (ИБС) 38 (45\%), гипертоническая болезнь (ГБ) 50 (59 \%), сахарный диабет второго типа (СД2) - 14 (17\%), постинфарктный кардиосклероз - 20 (24\%), острые и хронические нарушения мозгового кровообращения в анамнезе - 28 (33\%), курение - 42 (50 \%), ожирение - 13 (15\%) пациентов.

Курение как отдельный фактор риска включен в виду того, что, по результатам большинства исследований, курение повышает риск развития всех болезней системы кровообращения: коронарной болезни сердца, мозгового инсульта, заболеваний периферических артерий [6; 7]. Только фактор «курение» был статистически значим для выявления коронарного атеросклероза, имея увеличение отношения шансов до 7,06, а такие факторы как семейный сердечнососудистый анамнез, СД2, уровни общего холестерина и липопротеинов низкой плотности (ЛПНП) не были статистически значимы [6].

Компоненты метаболического синдрома у больных МФА распределились следующим образом: увеличение артериального давления (АД) до 130/85 мм pm cm имело место у 64 (76\%), причем 50 (59 \%) из них страдали ГБ; гипергликемия более 5,6 ммоль/л и/или СД2 - были у 36 (43\%), гипертриглицеридемия выше 1,7 ммоль/л либо гиполипидемическая терапия - у 61 (73 \%), ожирение - у 13 (15\%) пациентов (рис.).

Рисунок.

Распределение компонентов МС у больных периферическим и мультифокальным атеросклерозом, (\%).

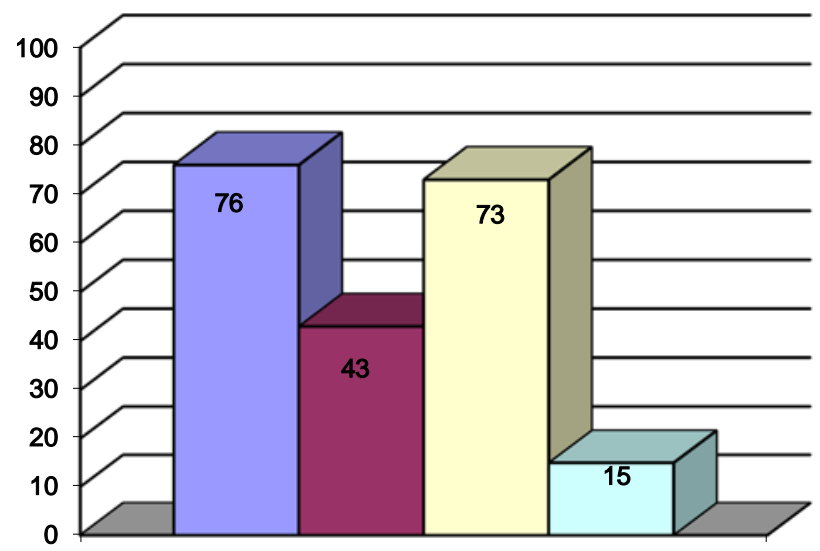

口АД $130 / 85$

чглю > 5,6 ммоль/л

वТГ > 1,7 ммоль/л

口имТ > $30 \mathrm{kr} / \mathrm{M} 2$ 
Как видно из рисунка, ожирение и избыточная масса тела у обследованного контингента больных с МФА встречалось реже, чем артериальная гипертензия и гипертриглицеридемия. Также имелась существенная разница в распределении компонентов МС у больных МФА по сравнению с пациентами с ИБС. Как было установлено нами ранее, у пациентов с ИБС артериальная гипертензия встречалась у 100 \%, избыточная масса тела - у 98 \%, ожирение - у $56 \%$, нарушение толерантности к глюкозе и гипергликемия - у 40 \%, дислипидемия - у $52 \%$ больных [8]. Как видно из этих данных, превалирующими компонентами МС у больных ИБС были увеличение АД и ИМТ, тогда как у пациентов с МФА и поражением магистральных артерий нижних конечностей преобладает гипертриглицеридемия и увеличение АД. Увеличение содержания глюкозы в крови более 5,6 ммоль/л или СД2 встречаются с одинаковой частотой при коронарном и мультифокальном атеросклерозе.

Представляет интерес распределение компонентов метаболического синдрома среди пациентов с АМНК и МФА в зависимости от вида и количества пораженных артериальных бассейнов (табл. 1).

Таблица 1. Компоненты МС у больных МФА

\begin{tabular}{|c|c|c|c|c|}
\hline Группы больных & АД $<130 / 85$ & $\begin{array}{c}\text { ГЛЮ } \\
<\mathbf{5 , 6} \text { ммоль/л } \\
\end{array}$ & $\begin{array}{c}\text { ТГ } \\
<1,7 \text { ммоль/л } \\
\end{array}$ & $\begin{array}{c}\text { ИМТ } \\
<30 \text { кг } / \mathrm{M}^{2} \\
\end{array}$ \\
\hline 1 гр. (АМНК) $n=30,100 \%$ & $13(43 \%)$ & $9(30 \%)$ & $25(83 \%)$ & $0(0 \%)$ \\
\hline $\begin{array}{l}2 \text { гр. }(\text { AMHK }+ \text { ACCA }) n=24, \\
100 \%\end{array}$ & $23(96 \%)$ & $10(42 \%)$ & $15(62 \%)$ & $1(4 \%)$ \\
\hline $\begin{array}{l}3 \text { гр. (AMHK + ACKA) } n=12, \\
100 \%\end{array}$ & $11(92 \%)$ & $4(33 \%)$ & $8(67 \%)$ & $3(25 \%)$ \\
\hline $\begin{array}{l}4 \text { гр. (ACCA + АCКА }) \\
n=8,100 \%\end{array}$ & $7(87 \%)$ & $5(62 \%)$ & $6(75 \%)$ & $4(50 \%)$ \\
\hline $\begin{array}{l}5 \text { гр. (АМНК + ACCA + ACKA) } \\
n=10,100 \%\end{array}$ & $10(100 \%)$ & $8(80 \%)$ & $7(70 \%)$ & $6(60 \%)$ \\
\hline
\end{tabular}

Как видно из табл. 1, увеличение АД более 130/85 мм рm cm наблюдалось менее, чем у половины больных с периферическим атеросклерозом, а при МФА - у подавляющего большинства больных (87-100 \%), причем у больных с атеросклеротическим поражением трех артериальных бассейнов - в 100 \% случаев. Гипертриглицеридемия оказалась наиболее часто встречаемым из компонентов МС, наблюдаясь у $2 / 3$ больных МФА и у $83 \%$ больных с периферическим атеросклерозом, реже у больных МФА наблюдалась гипергликемия.
Отчетливо прослеживается значение гипергликемии у пациентов с поражением сонных и коронарных сосудов, а также при развитии МФА в трех артериальных бассейнах - у $80 \%$ пациентов.

Увеличения ИМТ не отмечено ни в одном случае периферического атеросклероза, оно наблюдалось лишь у 4 \% пациентов с АМНК в сочетании с поражением артерий каротидного бассейна. Количество пациентов с ожирением значительно увеличивалось в третьей группе, имевших поражение коронарных сосудов, а при МФА с поражением трех арте- 
риальных бассейнов оно достигало $60 \%$. У пациентов с МФА с поражением коронарных артерий ожирение с увеличением ИМТ более 30 кг/м² отмечалось у 50-60 \% пациентов. Из этих данных явствует, что значимость ожирения как неблагоприятного фактора развития атеросклероза наиболее велика при поражении коронарных артерий.

Изучение компонентов МС в зависимости от вовлечения в атеросклеротический процесс сосудов различных артериальных бассейнов позволило установить следующее. При периферическом атеросклерозе наиболее часто встречается гипертриглицеридемия без ожирения; при МФА с вовлечением артерий каротидного бассейна - артериальная гипертензия и гипертриглицеридемия, при МФА со стенозом коронарных и каротидных артерий без поражения магистральных сосудов нижних конечностей - артериальная гипертензия, ожирение и гиперхолестеринемия. У пациентов МФА с поражением трех артериальных бассейнов имело место наличие полного кластера MC в $60 \%$ случаев, тогда как у больных с АМНК при поражении артерий одного бассейна - в $30 \%$ случаев, что наполовину меньше, чем при МФА. Это указывает на высокую значимость неблагоприятного влияния проявлений МС на развитие МФА.

Отметим, что по данным литературы, MC - качественно новое патологическое состояние, при котором комплекс сцепленных на патохимическом и патофизиологическом уровне факторов обусловливает чрезвычайно высокий суммарный риск развития заболеваний системы кровообращения, связанных с атеросклерозом. Сочетание инсулинорезистентности, артериальной гипертензии и дислипидемии, оказывает трудно объяснимый, но чрезвычайно сильный атерогенный эффект, увеличивающий повреждающий потенциал каждого компонента МС в конечном итоге в 2-3 раза [9].

Атеросклеротическое поражение одного из сосудистых бассейнов может служить фактором риска развития поражения других бассейнов [10]. Нами было выявлено, что при увеличении количества пораженных артериальных бассейнов возрастает отрицательное влияние гиперхолестеринемии, гипертриглицеридемии и абдоминального ожирения. Именно у больных с коронарным атеросклерозом при МФА имелись сильные прямые связи ИМТ/СРБ $(r=0,76, p>0,05)$, косвенно указывая на вклад адипоцитокинов (PAI-1, апелин, адипоцитный белок, связывающий жирные кислоты) в развитие системного воспаления и метаболических. расстройств при МФА.

Проявления окислительного стресса в виде увеличения концентрации МДА имели место у всех обследованных больных, но выраженность их была неодинакова. Так, у пациентов с АМНК увеличение содержания МДА отмечалось в 1,5 раза относительно контроля, что достоверно ниже, чем у больных МФА (увеличение МДА в два и более раз относительно контроля). Одной из особенностей, выявленных нами, является то, что МФА с поражением сонных и коронарных артерий сопровождается высоким уровнем окислительного стресса, вероятно, за счет повышенной чувствительности мозговых и сердечных тканей к гипоксии, уязвимости от токсических эффектов активных форм кислорода - АФК (табл. 2). 
Вестник Новосибирского государственного педагогического университета

5(21)2014 www.vestnik.nspu.ru ISSN 2226-3365

Таблица 2.

Некоторые показатели липидного обмена, ОС, воспаления, контрактильной способности миокарда у больных периферическим и мультифокальным атеросклерозом

\begin{tabular}{|c|c|c|c|c|c|c|c|c|}
\hline Группы больных & $\begin{array}{l}\text { ИМТ, } \\
\kappa \Gamma / \mathbf{M}^{2} \\
\end{array}$ & $\begin{array}{c}\text { ТГ, } \\
\text { ммоль/л }\end{array}$ & $\begin{array}{c}\text { ХC, } \\
\text { ммоль/л }\end{array}$ & $\begin{array}{l}\text { СРБ, } \\
\text { Мг/л }\end{array}$ & $\begin{array}{c}\text { МДА, } \\
\text { нмоль/л }\end{array}$ & $\begin{array}{l}\text { ОЛ, } \\
10 \% \text { л }\end{array}$ & $\begin{array}{l}\mathrm{CO} Э \\
\text { мм/ч }\end{array}$ & $\Phi B, \%$ \\
\hline Контроль, $n=15$ & $\begin{array}{l}24,0 \pm \\
0,9\end{array}$ & $0,9 \pm 0,1$ & $\begin{array}{l}3,9 \pm \\
0,3\end{array}$ & $\begin{array}{l}4,4 \pm \\
0,8\end{array}$ & $\begin{array}{l}4,66 \pm \\
0,25\end{array}$ & $\begin{array}{l}4,9 \pm \\
0,4\end{array}$ & $\begin{array}{l}9,8 \pm \\
1,9\end{array}$ & $\begin{array}{l}61,0 \pm \\
4,2\end{array}$ \\
\hline 1 гр. (AMHK), $n=30$ & $\begin{array}{l}24,3 \pm \\
0,6\end{array}$ & $\begin{array}{l}2,0 \pm \\
0,1^{*}\end{array}$ & $\begin{array}{l}4,9 \pm \\
0,1^{*}\end{array}$ & $\begin{array}{l}10,3 \pm \\
0,5^{*}\end{array}$ & $\begin{array}{l}7,13 \pm \\
0,15^{*} \\
\end{array}$ & $\begin{array}{l}8,2 \pm \\
0,4^{*}\end{array}$ & $\begin{array}{l}18,5 \pm \\
1,2 *\end{array}$ & $\begin{array}{l}61,4 \pm \\
4,1\end{array}$ \\
\hline $\begin{array}{l}2 \text { гр. (AMHK + ACCA), } n= \\
24\end{array}$ & $\begin{array}{l}25,1 \pm \\
0,9\end{array}$ & $\begin{array}{l}1,9 \pm \\
0,1^{*}\end{array}$ & $\begin{array}{l}4,6 \pm \\
0,3^{*}\end{array}$ & $\begin{array}{l}14,5 \pm \\
1,8^{*}\end{array}$ & $\begin{array}{l}8,77 \pm \\
0,39 *\end{array}$ & $\begin{array}{l}6,7 \pm \\
0,7^{*}\end{array}$ & $\begin{array}{l}12,3 \pm \\
1,9\end{array}$ & $\begin{array}{l}55,6 \pm \\
2,7^{*}\end{array}$ \\
\hline $\begin{array}{l}3 \text { гр. (АМНК + АCКА }), n= \\
12\end{array}$ & $\begin{array}{l}28,8 \pm \\
1,7^{*}\end{array}$ & $\begin{array}{l}2,7 \pm \\
0,3^{*}\end{array}$ & $\begin{array}{l}5,3 \pm \\
0,1^{*}\end{array}$ & $\begin{array}{l}10,2 \pm \\
0,5^{*}\end{array}$ & $\begin{array}{l}10,72 \pm \\
0,26^{*}\end{array}$ & $\begin{array}{l}7,4 \pm \\
0,5^{*}\end{array}$ & $\begin{array}{l}7,8 \pm \\
0,6\end{array}$ & $\begin{array}{l}38,8 \pm \\
2,8^{*}\end{array}$ \\
\hline $\begin{array}{l}4 \text { гр. (ACCA + ACKA), } n= \\
8\end{array}$ & $\begin{array}{l}30,2 \pm \\
1,1^{*}\end{array}$ & $\begin{array}{l}1,7 \pm \\
0,1^{*}\end{array}$ & $\begin{array}{l}5,1 \pm \\
0,2^{*}\end{array}$ & $\begin{array}{l}5,9 \pm \\
0,2^{*}\end{array}$ & $\begin{array}{l}10,91 \pm \\
0,49 *\end{array}$ & $\begin{array}{l}6,6 \pm \\
0,5^{*}\end{array}$ & $\begin{array}{l}7,9 \pm \\
0,5\end{array}$ & $\begin{array}{l}52,6 \pm \\
1,9 *\end{array}$ \\
\hline $\begin{array}{l}5 \text { гр. (AMHК + ACCA + } \\
\text { АCКА }, n=10\end{array}$ & $\begin{array}{c}27,6 \pm \\
1,7\end{array}$ & $\begin{array}{l}1,9 \pm \\
0,2^{*}\end{array}$ & $\begin{array}{l}4,9 \pm \\
0,3^{*}\end{array}$ & $\begin{array}{c}12,1 \pm \\
2,0^{*}\end{array}$ & $\begin{array}{c}10,23 \pm \\
0,54^{*}\end{array}$ & $\begin{array}{c}6,7 \pm \\
0,5^{*}\end{array}$ & $\begin{array}{c}12,1 \pm \\
2,6\end{array}$ & $\begin{array}{c}50,4 \pm \\
2,8^{*}\end{array}$ \\
\hline
\end{tabular}

Кроме того, у больных МФА с поражением коронарных и сонных артерий окислительный стресс был тесно связан с воспалением: связь СРБ/МДА была прямой сильной $(r=82, p>0,05)$.

В целом, для МФА с поражением коронарных артерий характерным стало превалирование окислительного стресса, а при МФА с АМНК (1, 2, 3 группы) - было более выражено воспаление. Это проявилось увеличением СРБ до 10,3 - 14,5 мг/л; общих лейкоцитов до 7,4-8,2 * 10\%/л с гипорегенераторным сдвигом лейкоцитарной формулы влево - индекс сдвига составил 0,11-0,09, что указывает на тяжелую форму воспаления при МФА с поражением артерий нижних конечностей.

Наличие воспаления и ОС у больных МФА негативно отразилось на контрактильной способности миокарда - величине фракции выброса (ФВ) левого желудочка, которая была снижена в 1,3-1,5 раза у больных МФА. Кроме того имелись сильные корреляционные связи ФВ/СРБ $(r=-93, p>0,05)$ и ФВ/МДА $(r=-94, p>0,05)$ у пациентов МФА с поражением артерий трех сосудистых бассейнов, что характеризует взаимовлияние воспаления, окислительного стресса и состояние сократительной способности миокарда.

В литературе широко обсуждается вопрос прогностической значимости наличия MC для определения кардиоваскулярного риска и риска развития СД2. Так, у лиц с МС риск СД2 увеличивается в 3-5 раз, преимущественно за счет вклада гипергликемии и увеличения соотношения объёма талии к объёму бедер [11]; риск развития сердечнососудистых заболеваний (СС3) и инсульта - увеличивается в три раза, смертность от СС3 - шесть раз. Метаанализ, объединивший 87 исследований и 951083 пациента, показал, что наличие МC, определенного по критериям NCEP и AHA/NHLBI, ассоциировалось с увеличением неблагоприятных исходов СС3 в два раза, а общей смертности - в 1,5 раза. В проспективном исследовании с участием 129655 пациентов указано, что МС имеет прогностическое значение у лиц до 65 лет, а у людей старше 65 особую значимость приобретают гипергликемия и гипертензия, нежели вся совокупность кластера МС [12; 13]. Данные о влиянии МС 
на течение окклюзирующих поражений артерий нижних конечностей единичны. Как показало наше исследование, при поражении атеросклеротическим процессом магистральных артерий нижних конечностей имеет место воспаление тяжелой степени, а из кластера МС преобладает гипертриглицеридемия. При МФА с вовлечением коронарных артерий отмечается гиперхолестеринемия, увеличение ИМТ, а при поражении артерий каротидного бассейна - увеличение АД.

\section{Выводы:}

1. Из компонентов МС при АМНК наиболее часто встречается гипертриглицеридемия без ожирения; при МФА с вовлечением артерий каротидного бассейна - артериальная гипертензия и гипертриглицеридемия, при МФА со стенозом/окклюзией коронарных и каротидных артерий без поражения магистральных сосудов нижних конечностей - артериальная гипертензия, ожирение и гиперхолестеринемия.

2. У пациентов МФА с поражением трех артериальных бассейнов в два раза чаще встречается полный кластер МС (60 \% случаев) по сравнению атеросклеротическим поражением магистральных артерий нижних конечностей (30 \% случаев), что указывает на высокую значимость неблагоприятного влияния проявлений МС на развитие МФА.

3. МФА с поражением коронарных артерий характеризуется превалированием окислительного стресса, а при АМНК более выражено воспаление.

4. Провоспалительный и прооксидантный статус являются факторами развития и прогрессирования МФА.

\section{СПИСОК ЛИТЕРАТУРЫ}

1. Митьковская Н. П., Григоренко Е. А., Патекж И. В., Статкевич Т. В., Курак Т. А., Терехов В. И., Швед М. В., Шумская Е. Н. Ранняя диагностика атеросклероза (лекция) // Кардиология в Беларуси.- 2012.- № 6 (25). - С. 134-155.

2. Авилова М. В., Космачева Е. Д. Мультифокальный атеросклероз: проблема сочетанного атеросклеротического поражения коронарного и брахиоцефального бассейнов // Креативная кардиология.- 2013. - № 1. -С. 5-13.

3. Ивченко О. А. Клинико-патогенетическое обоснование методов коррекции синдрома Лериша и атеросклеротических окклюзий артерий нижних конечностей: автореф. дис. ... докт. мед. наук. - М., 1990.- 40 с.

4. Пасечник А. В., Моисеева Е. Г., Фролов В. А., Дроздова Г. А. Воспаление и метаболические нарушения: учебно-метод. пособие. М., 2011. - 34c.

5. Huang P. L. A comprehensive definition for metabolic syndrome. Disease model \& mechanisms. 2009. - № 2. - pp. 231-237.

6. Gaisenok O. V., Deev A. D., Mazaev V. P., et al. The role of the known risk factors as predictors of detection atherosclerotic lesion of coronary and carotid arteries. Preventive medicine. 2012. № 15 (2). - p. 30.

7. WHO Report on the Global Tobacco Epidemic: Warning about the dangers of tobacco. 2012. [Electronic resours]. Accessed: http://whqlibdoc.who.int/hq/2011/WHO_NMH_TFI_11.3_eng. pdf webcite. (available at: 13.04.2014)

8. Хайбуллина 3. Р., Косникова И. В., Собиржанова Ч. К. Метаболические нарушения у больных ишемической болезнью сердца при различных типах нарушения васкуляризации миокарда // Universum: Медицина и фармакология: электрон. научн. журн. 2014. - № 4 (5). 
[электронный ресурс]. - Режим доступа: http://7universum.com/ru/med/archive/item/1226 (дата обращения: 13.04.2014).

9. Рагино Ю. И. Факторы и механизмы коронарного атеросклероза и его осложнений // Атеросклероз. - 2012. - № 1. - С. 61-65.

10. Гаврилова Н. Е., Метельская В. А., Перова Н. В., Яровая Е. Б., Мазаев В. П., Уразалина С. Ж., Бойцов С. А. Взаимосвязь между выраженностью коронарного атеросклероза, факторами риска и маркерами атеросклеротического поражения каротидных и периферических артерий // Кардиоваскулярная терапия и профилактика. - 2013. - № 12(1). - С. 40-45.

11. Stolar M. Metabolic syndrome: Controversial but useful. Cleveland clinic journal of medicine.2007. - № 74 (3). - pp. 199-208.

12. Pohjantahti-Maaroos H., Palomaki A. Comparison of metabolic syndrome subjects with and without erectile dysfunction - levels of circulating oxidised LDL and arterial elasticity. International Journal of Clinical Practise. 2011. - № 65. - pp. 274-280.

13. Thomas N., Phillips A. C., Carroll D. The metabolic syndrome adds utility to prediction of mortality over its components. Atherosclerosis. 2009. - № 210. - pp. 256-261. http://dx.doi.org/10.1016/j.atherosclerosis.2009.10.045. (дата обращения: 13.04.2014). 
DOI: $10.15293 / 2226-3365.1405 .14$

Khaybullina Zarina Ruslanovna, Doctor of Medicine, Chief of Biochemistry and Microbiology Department, Republican Specialized Centre of Surgery named after academician V. Vakhidov, Tashkent, Uzbekistan.

E-mail: zr-khaybullina@rambler.ru

Kosnikova Irina Victorovna, Candidate of Biological Science, Biochemistry and Microbiology Department, Republican Specialized Centre of Surgery named after academician V. Vakhidov, Tashkent, Uzbekistan.

\title{
COMPONENTS OF THE METABOLIC SYNDROME AT PATIENTS WITH THE MULTIFOCAL ATHEROSCLEROSIS
}

\begin{abstract}
The article is devoted to studying of components of a metabolic syndrome at patients with multifocal atherosclerosis (MFA). Changes of lipid's, carbohydrate's metabolism parameters, markers of a system inflammation and oxidizing stress are analyzed at patients with MFA, including atherosclerotic damage in various arterial pools (carotid, coronary, iliac-femoral) and it's combinations. Materials and methods of research included the analysis of the clinic and laboratory data at 84 patients with a peripheral and multifocal atherosclerosis. It is established, that at a peripheral atherosclerosis of the main arteries of a leg (AMAL) from components of metabolic syndrome (MS) most frequently observed hyperthreeglyceridemia without obesity. Arterial hypertension and hyperthreeglyceridemia observed at MFA, including carotid arteries damage; obesity and hypercholesterolemia were at patients with stenosis / occlusion of coronary and carotid arteries without atherosclerosis in iliac-femoral vessels. Presence of full cluster of MS observed in $60 \%$ of cases at patients with damage of 3 arterial pools, whereas at patients with AMAL ( damage of 1 arterial pool) it was only in $30 \%$ of cases, that half is less, than at MFA. It specifies the high importance of adverse influence of MS components to MFA progression. It was established, MFA, including carotid and coronary arteries it is accompanied by a high level of oxidizing stress, probably, due to the high sensitivity of brain and heart tissues to hypoxia and vulnerability from toxic effects of reactive oxygen species. At patients with coronary and carotids atherosclerosis the oxidizing stress was closely connected to an inflammation: correlation between C-reactive protein and malondialdehyde levels has made $(r=82, p>0,05)$. For MFA, including coronary arteries damage the prevalence of oxidizing stress was established, at MFA with AMAL the inflammation was more expressed. Inflammation and oxidizing stress are factors of development and progressing of MFA.

\section{Keywords}

multifocal atherosclerosis, peripheral atherosclerosis of the main arteries of a leg, metabolic syndrome, inflammation, oxidizing stress, hypertrigliceridemia.
\end{abstract}

\section{REFERENCES}

1. Mit'kovskaja N. P., Grigorenko E. A., Patekzh I. V., Statkevich T. V., Kurak T. A., Terehov V. I., Shved M. V., Shumskaya E. N. Early diagnostics of an atherosclerosis (lecture). Cardiology in Belorussia. 2012, n. 6 (25), pp. 134-155. (In Russian) 
2. Avilova M. V., Cosmacheva E. D. Multifocal an atherosclerosis: a problem of complex atherosclerotic defeat of coronary and brachicephalic arterial pools. Creative cardiology. 2013, n. 1, pp. 5-13. (In Russian)

3. Ivchenko O. A. Kliniko-pathogenetic bases of methods of correction of Lerish syndrome and atherosclerotic occlusions of arteries of the legs. bottom finitenesses. Moscow, 1990. (In Russian)

4. Pasechnik A. V., Moiseeva E. G., Frolov V. A., Drozdova G. A. Inflammation and metabolic damage. The manual. Moscow, 2011. (In Russian)

5. Huang P. L. A comprehensive definition for metabolic syndrome. Disease model \& mechanisms. 2009, n. 2, pp. 231-237.

6. Gaisenok O. V., Deev A. D., Mazaev V. P., et al. The role of the known risk factors as predictors of detection atherosclerotic lesion of coronary and carotid arteries. Preventive medicine. 2012, n. 15 (2), pp. 30.

7. WHO Report on the Global Tobacco Epidemic: Warning about the dangers of tobacco. 2012. Accessed: http://whqlibdoc.who.int/hq/2011/WHO_NMH_TFI_11.3_eng.pdf webcite (available at: 13.04.2014)

8. Khaybullina Z. R., Kosnikova I. V. Metabolic disorders at patients with ischemic heart disease at various types of myocardium vascularization disturbances. Universum: Medicine and fharmacology. Electron scientific journal. 2014, n. 4 (5). Accessed: http://7universum.com/ru/med/archive/item/1226 (available at: 13.04.2014) (In Russian)

9. Ragino JU. I. Factor and mechanisms of a coronary atherosclerosis and its complications. Atherosclerosis. 2012, n. 1, pp. 61-65. (In Russian)

10. Gavrilova N. E., Metel'skaja V. A., Perova N. V., Yarovaya E. B., Mazaev V. P., Urazalina S. Z., Boytsov S. A. Interrelation between expressiveness of a coronary atherosclerosis, risk factors and markers of atherosclerotic damage of carotid and peripheral arteries. Cardiovascular therapy and prevention. 2013, n. 12 (1), pp. 40-45. (In Russian)

11. Stolar M. Metabolic syndrome: Controversial but useful. Cleveland clinic journal of medicine. 2007, n. 74 (3), pp. 199-208.

12. Pohjantahti-Maaroos H., Palomaki A. Comparison of metabolic syndrome subjects with and without erectile dysfunction - levels of circulating oxidised LDL and arterial elasticity. International Journal of Clinical Practise. 2011, n. 65, pp. 274-280.

13. Thomas N., Phillips A. C., Carroll D. The metabolic syndrome adds utility to prediction of mortality over its components. Atherosclerosis.2009. n. 210, pp. 256-261. http://dx.doi.org/10.1016/j.atherosclerosis.2009.10.045 (available at: 13.04.2014) 
УДК 616.12-005.4 + 577.158 + 616.153.857.915

\title{
ХАРАКТЕРИСТИКА МЕТАБОЛИЧЕСКИХ НАРУШЕНИЙ У БОЛЬНЫХ С РАЗЛИЧНЫМИ ТИПАМИ ПОРАЖЕНИЯ КОРОНАРНЫХ АРТЕРИЙ ПРИ ИШЕМИЧЕСКОЙ БОЛЕЗНИ СЕРДЦА
}

\author{
3. Р. Хайбуллина, Л. Г. Баженов, И. В. Косникова (Ташкент, Узбекистан)
}

Статья посвящена изучению метаболических нарушений у больных ишемической болезнью сердиа (ИБС). Анализируются изменения показателей липидного, углеводного, пуринового обмена, а также маркеров системного воспаления и окислительного стресса у пациентов с ИБС при различных типах поражения коронарных артерий (макро-, микроваскулярное поражение, отсутствие органического стеноза). Материаль и методы исследования включали в себя анализ данных коронаровентрикулографии и лабораторных тестов у 94 пачиентов с ИБС. Изучение показателей обмена веществ у больных ИБС с макрососудистым поражением коронарного русла выляило преобладание гиперурикемии и дислипидемии при одно- и двусосудистом поражении, гипергликемии - при трехсосудистом поражении венечных артерий, гиперлипидемии - при микроваскулярном поражении дистального русла. Установлена взаимосвязь окислительного стресса с указанными метаболическими сдвигами, а также зависимость интенсивности системного воспаления от типа поражения коронарных артерий. Показано, что гиперфибриногенемия, гиперурикемия, гипертриглицеридемия, дислипидемия и увеличение коэффициента атерогенности при высоком индексе массы тела являются мощными факторами развития ИБС при отсутствии органического поражения сосудов, сопровождаясь эндогенной интоксикацией и усилением липопероксидации, о чем свидетельствует увеличение уровня средних молекул плазмы и малонового диальдегида.

Ключевые слова: ишемическая болезнь сердия, окислительный стресс, гиперлипидемия, гиперурикемия, макрососудистое и микрососудистое поражение коронарных артерий.

Хайбуллина Зарина Руслановна - доктор медицинских наук, руководитель отделения биохимии с группой микробиологии, Республиканский специализированный центр хирургии им. академика В. Вахидова.

E-mail: zr-khaybullina@rambler.ru

Баженов Леонид Григорьевич - доктор медицинских наук, профессор, отделение биохимии с группой микробиологии, Республиканский специализированный центр хирургии им. академика В. Вахидова.

Косникова Ирина Викторовна - кандидат биологических наук, старший научный сотрудник, отделение биохимии с группой микробиологии, Республиканский специализированный центр хирургии им. академика В. Вахидова. 
Вестник Новосибирского государственного педагогического университета

5(21)2014 www.vestnik.nspu.ru

ISSN 2226-3365

Сердечнососудистые заболевания (CС3), по оценкам Всемирной организации здравоохранения, занимают первое место среди причин смертности населения индустриально развитых и развивающихся стран. Каждый год в мире от ишемической болезни сердца (ИБС) умирает 3,8 миллиона мужчин и 3,4 миллиона женщин, т. е. 7,2 млн человек, a к 2020 году эта цифра может достичь 11 млн человек [12]. В патогенезе СС3 все большее значение придают метаболическому синдрому, включая в него нарушения липидного, углеводного метаболизма, объясняя эти нарушения изменением гормональной регуляции со стороны инсулина (инсулинорезистентность) и гормонов жировой ткани: лептин, адипонектин [5]. Хроническое воспаление сосудистой стенки с поражением интимы сосудов и активным вовлечением эндотелия также все чаще называют причиной СС3. Воспалительная реакция признается одним из наиболее вероятных механизмов в развитии обострений ИБС. Эпидемиологические и клинические исследования показали, что величина базового уровня C-реактивного белка (СРБ) непосредственно связана с риском развития тяжелых СС3 и их осложнений острого инфаркта миокарда и мозгового инсульта [4]. Маркеры воспаления сосудистой стенки, повреждения эндотелия и миокарда могут нести полифункциональный характер, отражая единый патогенез различных клинических проявлений СС3, таких как метаболический синдром, гипертоническая болезнь, ИБС, и могут иметь прямое диагностическое и прогностическое значение, как по течению заболевания, так и по эффективности применяемой терапии.

Цель данного исследования: изучение характеристики метаболических нарушений, интенсивности окислительного стресса и системного воспаления у больных с различны- ми типами поражения коронарных артерий при ишемической болезни сердца.

\section{Материалы и методы исследований}

Обследовано 94 пациента с ИБС, госпитализированных в клинику Республиканского специализированного центра хирургии им. академика В. Вахидова (далее - РСЦХ им. ак. В. Вахидова) для проведения рентгенэндоваскулярных вмешательств. Мужчин было 69 (73\%), женщин - 25 (27\%); средний возраст обследованных составил $57,9 \pm 1,5$ лет. Количество и тип поражения коронарных сосудов классифицировали по АСС/АНА. Содержание общего холестерина (ХC), триглицеридов (ТГ), липопротеинов высокой плотности (ЛПВП), липопротеинов низкой плотности (ЛПНП), глюкозы (ГЛЮ), мочевой кислоты (МК), СРБ определяли на автоматическом биохимическом анализаторе «Vitros 350» фирмы «Ortho Clinical Diagnostics» (Германия). Концентрацию МДА (нмоль/мл) определяли колориметрическим методом по реакции с тиобарбитуровой кислотой (M. Michara), активность каталазы (усл. ед.) определяли на полуавтоматическом анализаторе «Screen Master Plus» фирмы «Hospitex Diagnostics» (Италия) по методу И. А. Переслегиной. Уровень средних молекул плазмы исследовали по методу Н. И. Габриелян. Содержание фибриногена (мг/л) определяли унифицированным гравиметрическим методом. Диагноз метаболического синдрома (MC) устанавливали на основании критериев Международной федерации диабета (IDF, 2005 год; пересмотр 2007 и 2009 гг.).

\section{Полученные результаты и их обсуждение}

Из 94 обследованных пациентов по результатам коронаровентрикулографии гемодинамически значимый стеноз коронарных артерий диагностирован у 70 человек (74 \%), 
Вестник Новосибирского государственного педагогического университета

5(21)2014 www.vestnik.nspu.ru ISSN 2226-3365

микроваскулярное поражение дистального сосудистого русла - у 16 (17\%), отсутствие органических изменений в коронарных сосудах - у 8 (9\%). В зависимости от распространенности поражения коронарного русла пациенты распределились следующим образом: однососудистое поражение - 18 человек (19 \%), двухсосудистое - 27 (29 \%), поражение трех эпикардиальных артерий 25 (26 \%). Сложный тип поражения (тип $B$ и $C)$ выявлен у 44 пациентов (47 \%). Сахарный диабет второго типа наблюдался у 19 человек (20 \%), постинфарктный коронарокардиосклероз - у 34 (36 \%).

Изучение показателей системного воспаления (СРБ, фибриногена), параметров окислительного стресса (МДА, каталазы), интенсивности эндогенной интоксикации (СМП) у больных ИБС выявило однонаправленность их изменений у всех пациентов (табл. 1).

Таблица 1

Показатели системного воспаления, окислительного стресса, эндогенной интоксикации у больных ИБС

\begin{tabular}{|c|l|l|l|l|l|}
\hline Показатели & СРБ, мг/л & \multicolumn{1}{|c|}{$\begin{array}{c}\text { МДА, } \\
\text { нмоль/л }\end{array}$} & $\begin{array}{c}\text { Каталаза } \\
\text { (усл. ед.) }\end{array}$ & $\begin{array}{l}\text { Фибрино- } \\
\text { ген, мг/л }\end{array}$ & СМП (УЕ) \\
\hline Контроль, $\mathrm{n}=15$ & $4,4 \pm 0,8$ & $4,66 \pm 0,25$ & $19,2 \pm 1,8$ & $3294 \pm 252$ & $0,011 \pm 0,001$ \\
\hline 1 сосуд, $\mathrm{n}=18$ & $5,2 \pm 0,7^{*}$ & $7,76 \pm 0,62^{*}$ & $40,8 \pm 2,3^{*}$ & $2464 \pm 77^{*}$ & $0,022 \pm 0,003^{*}$ \\
\hline 2 сосуда, $\mathrm{n}=27$ & $5,7 \pm 0,6^{*}$ & $10,40 \pm 0,81^{*}$ & $45,2 \pm 1,1^{*}$ & $2838 \pm 232$ & $0,034 \pm 0,002^{*}$ \\
\hline 3 сосуда, $\mathrm{n}=25$ & $6,6 \pm 0,7^{*}$ & $10,17 \pm 0,62^{*}$ & $35,3 \pm 1,3^{*}$ & $3770 \pm 266^{*}$ & $0,037 \pm 0,003^{*}$ \\
\hline $\begin{array}{c}\text { Микроваскулярное пораже- } \\
\text { ние, } \mathrm{n}=16\end{array}$ & $6,5 \pm 0,8^{*}$ & $10,28 \pm 1,10^{*}$ & $43,0 \pm 1,4^{*}$ & $3440 \pm 213$ & $0,028 \pm 0,003^{*}$ \\
\hline $\begin{array}{c}\text { Без органического стеноза, } \mathrm{n} \\
=8\end{array}$ & $2,5 \pm 0,4^{*}$ & $10,32 \pm 1,10^{*}$ & $44,0 \pm 3,0^{*}$ & $3770 \pm 65^{*}$ & $0,034 \pm 0,002$ \\
\hline \multirow{2}{*}{ * отличия достоверны относительно контроля, $\mathrm{p}<0,05$} & \\
\hline
\end{tabular}

Уровень СРБ был достоверно выше контрольного во всех группах $(\mathrm{p}>0,05)$, за исключением пациентов с отсутствием органических изменений в коронарных сосудах, у которых содержание СРБ было ниже контрольного. Обращает внимание отсутствие достоверных отличий показателей СРБ между подгруппами больных с макрососудистым поражением, что указывает на отсутствие зависимости роста концентрации СРБ от количества стенозированных артерий. Возможно, сам факт наличия атеросклеротического процесса в артериях обусловливает инициацию синтеза белков острой фазы воспаления в печени, независимо от количества вовлеченных сосудов и интенсивности стеноза [9].
У больных с микрососудистым поражением дистального русла уровень маркера системного воспалительного процесса СРБ был в 1,5 раза выше контрольного, что свидетельствует об ином механизме активации системного воспаления, предположительно связанным с реализацией метаболического синдрома. Инициаторами воспаления и окислительного стресса при МС могут быть адипоцитокины, вырабатываемые висцеральной жировой тканью [11], продукты пероксидации глюкозы при гипергликемии - метилглиоксаль, а также продукты липопероксидации ЛПНП - МДА, гидроксиноненаль [10].

Так, содержание конечного продукта липопероксидации МДА в крови было повы- 
шено относительно контроля в 1,7 раза у пациентов с однососудистым поражением и в 2,2 - 2,1 раза у больных с поражением 2 и 3 сосудов, в 2,2 раза - при микрососудистом поражении дистального русла. При отсутствии органических изменений в коронарных сосудах у пациентов с ИБС и МС уровень МДА также превышал контрольные показатели в 1,5 раза.

Увеличение показателя МДА в крови характеризует достаточно высокую интенсивность окислительного стресса (ОС) у пациентов с ИБС, причем независимо от степени стеноза коронарных сосудов, а также при микроваскулярном поражении в интактных сосудах. Это свидетельствует о различных механизмах активации ОС при ИБС, судить о которых возможно после более глубокого исследования параметров углеводного и липидного обмена.

Изучение компонентов метаболического синдрома у больных ИБС выявило, что артериальная гипертензия была у 100 \% больных, нарушение толерантности к глюкозе и гипергликемия - у 40 \%, дислипидемия у $52 \%$, избыточная масса тела - у $98 \%$, ожирение - у $56 \%$.

При этом индекс массы тела (ИМТ) характеризовал предожирение у больных с тяжелым стенозом 3 кардиальных сосудов, ожирение $1 \mathrm{~A}$ степени (ИМТ в пределах 30,0-32,49 кг/м²) - у пациентов с микрососудистым поражением дистального русла и ожирение $1 B$ (ИМТ в пределах 32,534,99 кг/м²) степени у пациентов без видимых стенозов коронарных сосудов. В группе больных со стенозированием 3 эпикардиальных артерий в $85 \%$ случаев имел место постинфарктный коронарокардиосклероз (ПИКС), у $22 \%$ больных - сахарный диабет второго типа средней тяжести в стадии суб- компенсации, а средний возраст составил 58,9 \pm 6,2 года (42-77 лет). У всех больных этой группы клинически диагностирована стенокардия напряжения ФК 3 , хроническая сердечная недостаточность (ХCH) 2А, ФК2, гипертоническая болезнь (ГБ) третьей степени, АГ 2-3, риск 4. Из анамнеза у 70 \% пациентов выявлено снижение массы тела в течение 3-10 месяцев, предшествовавших настоящему обращению в стационар. Возможно, в виду тяжести состояния, обусловленной перечисленными факторами, у данной группы больных наблюдалось некоторое снижение массы тела, следствием чего явилось наличие предожирения на момент обследования.

Наибольшие показатели ИМТ наблюдались у больных ИБС с отсутствием органического стеноза коронарных артерий, причем ожирение у них сочеталось с гипертриглицеридемией, гиперхолестеринемией, дислипидемией и увеличением коэффициента атерогенности, а также с гиперурикемией (табл. 2). Как видно, гипертриглицеридемия, соответствующая критериям МC (ТГ более 1,69 ммоль/л), отмечалась у больных с поражением трех сосудов и пациентов без органических стенозов сосудов (табл. 2). Эти две группы больных имели схожую клиническую картину ИБС и нарушений липидного обмена, однако механизм развития ишемии миокарда и морфологический субстрат поражения у них был различен. В первом случае преобладал органический стеноз венечных артерий, а во втором, возможно, их спазм, а также эндотелиальная дисфункция и другие факторы. 
Вестник Новосибирского государственного педагогического университета

5(21)2014 www.vestnik.nspu.ru ISSN 2226-3365

Таблица 2.

Показатели липидного, углеводного, пуринового обмена у больных ИБС

\begin{tabular}{|c|c|c|c|c|c|c|c|c|}
\hline Показатели & $\begin{array}{l}\text { ИМТ, } \\
\kappa г / \mathbf{M}^{2}\end{array}$ & $\begin{array}{c}\text { ТГ, } \\
\text { ммоль/л }\end{array}$ & $\begin{array}{c}\text { ХС, } \\
\text { ммоль/л }\end{array}$ & $\begin{array}{c}\text { ЛПВП, } \\
\text { ммоль/л }\end{array}$ & $\begin{array}{c}\text { ЛПНП, } \\
\text { ммоль/л }\end{array}$ & KA & $\begin{array}{c}\text { ГЛЮ, } \\
\text { ммоль/л }\end{array}$ & $\begin{array}{c}\text { МК, } \\
\text { мкмоль/ } \\
\text { л }\end{array}$ \\
\hline $\begin{array}{c}\text { Контроль, } \\
\text { n = } 15\end{array}$ & $\begin{array}{c}22,3 \pm \\
1,3\end{array}$ & $\begin{array}{c}0,86 \pm \\
0,12\end{array}$ & $\begin{array}{c}3,90 \pm \\
0,30\end{array}$ & $\begin{array}{c}1,34 \pm \\
0,11\end{array}$ & $\begin{array}{l}2,2 \pm \\
0,23\end{array}$ & $\begin{array}{c}2,08 \pm \\
0,2\end{array}$ & $4,2 \pm 0,4$ & $230 \pm 19 *$ \\
\hline 1 сосуд, $n=18$ & $\begin{array}{c}33,7 \pm \\
0,7 *\end{array}$ & $\begin{array}{l}1,56 \pm \\
0,12^{*}\end{array}$ & $\begin{array}{l}4,78 \pm \\
0,34^{*}\end{array}$ & $\begin{array}{c}1,08 \pm \\
0,06^{*}\end{array}$ & $\begin{array}{l}3,70 \pm \\
0,34^{*}\end{array}$ & $\begin{array}{l}3,51 \pm \\
0,38^{*}\end{array}$ & $5,3 \pm 0,5^{*}$ & $297 \pm 8^{*}$ \\
\hline 2 сосуда, $n=27$ & $\begin{array}{c}30,5 \pm \\
1,0^{*}\end{array}$ & $\begin{array}{c}1,59 \pm \\
0,11^{*}\end{array}$ & $\begin{array}{c}4,45 \pm \\
0,35^{*}\end{array}$ & $\begin{array}{c}1,20 \pm \\
0,11\end{array}$ & $\begin{array}{c}3,27 \pm \\
0,36^{*}\end{array}$ & $\begin{array}{c}2,83 \pm \\
0,30 *\end{array}$ & $6,3 \pm 0,4^{*}$ & $319 \pm 17^{*}$ \\
\hline 3 сосуда, $n=25$ & $\begin{array}{c}27,9 \pm \\
0,7^{*}\end{array}$ & $\begin{array}{l}1,90 \pm \\
0,20^{*}\end{array}$ & $\begin{array}{l}4,80 \pm \\
0,31^{*}\end{array}$ & $\begin{array}{c}1,06 \pm \\
0,07^{*}\end{array}$ & $\begin{array}{c}3,74 \pm \\
0,32^{*}\end{array}$ & $\begin{array}{l}3,74 \pm \\
0,40^{*}\end{array}$ & $6,9 \pm 0,3^{*}$ & $315 \pm 22 *$ \\
\hline $\begin{array}{l}\text { Микроваску- } \\
\text { лярное пора- } \\
\text { жение, n = } 16\end{array}$ & $\begin{array}{c}30,8 \pm \\
0,8^{*}\end{array}$ & $\begin{array}{l}1,53 \pm \\
0,13^{*}\end{array}$ & $\begin{array}{l}4,72 \pm \\
0,40^{*}\end{array}$ & $\begin{array}{l}1,07 \pm \\
0,08^{*}\end{array}$ & $\begin{array}{c}3,65 \pm \\
0,46^{*}\end{array}$ & $\begin{array}{c}3,46 \pm \\
0,37 *\end{array}$ & $5,9 \pm 0,2^{*}$ & $287 \pm 12^{*}$ \\
\hline $\begin{array}{c}\text { Без органиче- } \\
\text { ского стеноза, } \\
\text { n = } 8\end{array}$ & $\begin{array}{c}34,0 \pm \\
0,5^{*}\end{array}$ & $\begin{array}{l}1,73 \pm \\
0,20 *\end{array}$ & $\begin{array}{l}5,45 \pm \\
0,40 *\end{array}$ & $\begin{array}{l}1,05 \pm \\
0,07^{*}\end{array}$ & $\begin{array}{l}4,40 \pm \\
0,30 *\end{array}$ & $\begin{array}{l}4,40 \pm \\
0,38^{*}\end{array}$ & $5,1 \pm 0,2^{*}$ & $380 \pm 9 *$ \\
\hline
\end{tabular}

Согласно полученным результатам, можно предположить, что гипертриглицеридемия, дислипидемия и увеличение коэффициента атерогенности при высоком ИМТ являются мощными факторами риска развития ИБС при отсутствии органического поражения сосудов, сопровождаясь эндогенной интоксикацией и усилением липопероксидации, о чем свидетельствует обозначенное выше увеличение СМП и МДА. Именно в этой группе больных отмечалась наиболее высокая концентрация фибриногена в плазме крови, указывая на предтромботическое состояние. Последнее является очень серьезным предиктором развития тромбоза коронарных артерий и инфаркта миокарда, развития больших коронарных событий. Кроме того, из профессиональной литературы известно о влиянии гипер- и дислипидемии на активность ангиотензинпревращающего фермента, что расценивается как возможный механизм вторично- го гиперальдостеронизма и артериальной гипертензии [2].

Еще один настораживающий аспект нарушений метаболизма у больных с отсутствием органического поражения коронарных артерий, обследованных нами, - гиперурикемия до 380 мкмоль/л. Согласно критериям «EULAR» (2006), гиперурикемией считается увеличение уровня МК более 360 мкмоль/л для мужчин и женщин. Мы полагаем, что гиперурикемия вносит существенный вклад в развитие ИБС у данной группы больных, поскольку известно о влиянии мочевой кислоты на активность эндогенного ренина, на соотношение интима-медия; а поглощение клетками мочевой кислоты через URAT-1, имеющийся не только в почечном тубулярном эпителии, но и в эндотелиоцитах, приводит к накоплению мочевой кислоты в эндотелиоцитах и фибробластах, следствием чего является эндотелиальная дисфункция и ги- 
перпродукция соединительнотканных элементов [7]. Указанные сдвиги наряду с активацией генерации активных форм кислорода способствуют образованию высокотоксичных продуктов пероксидации, активации мембранодеструктивных процессов, запуску апоптоза и некроза в сосудистой стенке, поддерживая хроническое воспаление и прогрессирование атеросклеротических изменений [3].

Примечательно, что гипергликемии в данной группе не наблюдалось, тогда как у больных с атеросклерозом коронарных артерий и микрососудистым поражением дистального русла уровень глюкозы в крови был увеличен, причем пропорционально количеству пораженных сосудов. У пациентов с поражением двух и трёх артерий диагностирован преддиабет, а у больных с микроваскулярным поражением дистального русла (МВП) - нарушение толерантности к глюкозе, рассматриваемое как компонент метаболического синдрома.

Картина периферической крови у больных ИБС характеризовалась лимфоцитозом, наиболее выраженным у пациентов без органического сужения коронарных сосудов и моноцитозом при макро- и микрососудистом поражении коронарного русла. Увеличение содержания лимфоцитов на 11,4 \% относительно контроля наблюдалось в группах больных с микрососудистым поражением и при отсутствии органического сужения в коронарных артериях (на 15,3 \%), что, вероятно, обусловлено снижением сопротивляемости организма, либо реакцией на вирусную инфекцию [12], в том числе и инфицирование цитомегаловирусом [8]. Как показали проведенные нами ранее исследования, у 85 \% пациентов ИБС был увеличен титр антител к ЦМВ [1].

Содержание моноцитов, отражающее состояние макрофагально-моноцитарной си- стемы, активируемой при инфекциях и атеросклерозе, было увеличено относительно контроля в 1,$8 ; 1,7 ; 2,2 ; 1,9 ; 1,5$ раза соответственно у больных с одно-, двух-, трехсосудистым, микрососудистым поражением и отсутствием органического стеноза в коронарных артериях. Возможной причиной моноцитоза при ИБС с макро- и микрососудистым поражением артерий является активация поглощении модифицированных (окисленных) ЛПНП, приобретающих антигенные свойства, как из стенок сосудов, так и из крови посредством моноцитов и макрофагов. Наличие иммунно-воспалительной реакции у пациентов с ИБС как при макро, так и при микрососудистом поражении доказывается резким увеличением СОЭ в их крови. При отсутствии органического поражения коронарных артерий показатели эозинофилов и СОЭ достоверно не отличаются от контрольных, равно как и содержание СРБ, что указывает на отсутствие активации системного воспаления. Напротив, макро- и микрососудистое поражение коронарного русла сопровождается иммунно-воспалительной реакцией, о чем свидетельствует высокие показатели СРБ, СОЭ, моноцитоз, эозинофилез.

\section{Выводы:}

1. У больных ишемической болезнью сердца при поражении одного и двух коронарных сосудов из метаболических нарушений преобладает гиперурикемия и дислипидемия, при трехсосудистом поражении венечных артерий - гипергликемия, при микроваскулярном поражении дистального русла гиперлипидемия.

2. Установлена зависимость интенсивности системного воспаления от типа поражения коронарных артерий и взаимосвязь окислительного стресса с метаболическими сдвигами у больных ИБС. 
3. Гиперфибриногенемия, гиперурикемия, гипертриглицеридемия, дислипидемия и увеличение коэффициента атерогенности при высоком индексе массы тела являются основными факторами развития ИБС при отсутствии органического поражения сосудов, сопровождаясь эндогенной интоксикацией и усилением генерации активных форм кислорода.
4. Макро- и микрососудистое поражение коронарного русла при ИБС сопровождается иммунно-воспалительной реакцией, о чем свидетельствует высокие показатели СРБ, СОЭ, моноцитоз, эозинофилез.

5. Дисметаболический фон, провоспалительный и прооксидантный статус являются факторами развития и прогрессирования ИБС.

\section{СПИСОК ЛИТЕРАТУРЫ}

1. Абдуллаева С. Д., Баженов Л. Г., Джумаева Н. Э., Усманходжаева Г. Х. Цитомегаловирусная инфекция у больных ИБС // Инфекция, иммунитет и фармакология. - 2013. Спецвыпуск.- С. 12-15. (Узб. яз.)

2. Альтшулер Б. Ю., Ройтман А. П., Долгов В. В., Соколов А. В. Влияние гипер- и дислипидемий на активность ангиотензинпревращающего фермента (о биохимических нарушениях при метаболическом синдроме) // Терапевтический архив. - 2005.- № 1.- С. 51-56.

3. Ибрагимов У. К., Хайбуллина 3. Р. Биологические мембраны: моногр. - Ташкент: Изд-во ТашПМИ, 2009.- 134 с. (Узб. яз.)

4. Ройтман А. П. Лабораторные маркеры сердечнососудистых заболеваний. Значение в оценке эффективности терапии: автореф. дис. ... докт. мед. наук. - М., 2006. - 51 с.

5. Федорова М. М., Ройтман А. П. Прогностическое значение адипонектина как маркера метаболического синдрома // Лаборатория. - 2009.- № 1.- С. 9-10.

6. Чернышев А. В. Многоцелевая стратегия профилактики и восстановительного лечения больных ишемической болезнью сердца и группы риска: автореф. дис.... докт. мед. наук. M., 2006.- $42 \mathrm{c}$.

7. Angelo L. Gaffo, Lawrence N. Edward, Kenneth G. Saag. Hyperuricemia and cardiovascular disease: how strong is the evidence for a causal link? Arthritis Research and Therapy. 2009, no. 11, pp. 240 (DOI:10.1186/ar2761).

8. Bentz G. L., Yurochko A. D. Human CMV infection of endothelial cells induces an angiogenic response through viral binding to EGF receptor and beta1 and beta3 integrins. Proc. Natl. Acad. Sci. USA. 2008, no. 105 (14), pp. 5531-5536.

9. Crumpacker C. S. Invited commentary: human cytomegalovirus, inflammation, cardiovascular disease, and mortality. Am. J. Epidemiol. 2010, no. 172 (4), pp. 372-374.

10. Del Rio D., Stewart A. J., Pellegrini N. A review of recent studies on malondialdehyde as toxic molecule and biological marker of oxidative stress. Nutrition, Metabolism and Cardiovascular Diseases. 2005, no. 15, pp. 316-328.

11. Faulhaber-Walter R. Adipokines and central control in adenosine A1 receptor dependent glucose metabolism. Adipocyte. 2012, no. 1 (2), pp. 108-111.

12. Heseler K. Cytomegalovirus impairs the induction of indoleamine 2,3-dioxygenase mediated antimicrobial and immunoregulatory effects in human fibroblasts. Heseler K., Schmidt S. K., Spekker K., Sinzger C., Sorg R. V., Quambusch M., Zimmermann A., Meisel R., Däubener W. PLoS One. 2013, no. 15; 8 (5), p. e64442. 
DOI: $10.15293 / 2226-3365.1405 .15$

Khaybullina Zarina Ruslanovna, Doctor of Medicine, Head of Biochemistry and Microbiology Department, V. Vakhidov Republican Specialized Centre of Surgery, Tashkent, Uzbekistan.

E-mail: zr-khaybullina@rambler.ru

Bajenov Leonid Grigoryevich, Doctor of Medicine, Professor of Biochemistry and Microbiology Department, V. Vakhidov Republican Specialized Centre of Surgery, Tashkent, Uzbekistan.

Kosnikova Irina Victorovna, Doctor of Biology Sciences, Candidate of Biochemistry and Microbiology Department, V. Vakhidov Republican Specialized Centre of Surgery, Tashkent, Uzbekistan.

\title{
CHARACTERISTIC OF METABOLIC DISORDERS AT PATIENTS WITH ISCHEMIC HEART DISEASE WITH VARIOUS TYPES OF CORONARY ARTERIES DAMAGE
}

\begin{abstract}
The article is devoted to the problems of metabolic disorders at ischemic heart disease (IHD). Changes of lipid's, carbohydrate's, purin's metabolism parameters, markers of a system inflammation and oxidizing stress are analyzed at patients with ischemic heart disease with various types of coronary arteries damage (macro-, microvascular damage, absence of an organic stenosis). Materials and methods of research included the coronaroventriculography and laboratory tests data at 94 patients with ischemic heart disease. It is established the prevalence of hyperuricemia and dyslipidemia at patients with ischemic heart disease with macrovascular damage of one or two coronary vessels. Hyperglycemia is established at patients with stenosis of 3 coronary arteries, hyperlipidemia is established at patients with microvascular damage of peripheral coronary vessels. The interrelation of oxidizing stress with the specified metabolic shifts, and also dependence of intensity of a system inflammation on the type of coronary arteries damage is established. It is shown, that hyperfibrinogenemia, hyperuricemia, hypertrigliceridemia, dislipidemia and high body mass index are accompanied with endogenous intoxication, high level of radical oxygen species in the patients without organic stenosis of coronary vessels. This combination of metabolism disorders is powerful factor of IHD development in the patients without organic defeat of coronary vessels.
\end{abstract}

Keywords

ischemic heart disease, oxidizing stress, hyperuricemia, hyperlipidemia, macrovascular and microvascular damage of coronary arteries

\section{REFERENCES}

1. Abdullaeva S. D., Bajenov L. G., Djumaeva N. E., Usmanhodjaeva G. H. Cytomegalovirus infection at the patients of ischemic heart disease. Infection, immunity and pharmacology. 2013. Special issue, pp. 12-15. (In Uzbekistan)

2. Aitshuller B. U., Roytman A. P., Dolgov V. V., Sokolov A. V. Influence hyper- and dyslipidemya on angiotensinconverting enzyme activity (about biochemical disturbances at a metabolic syndrome). Therapeutic archive. 2005, no. 1, pp. 51-56. (In Russian)

3. Ibragimov U. K. Khaybullina Z. R. Biological membranes: monography, Tashkent, Publishing house of TasPMI. (In Uzbekistan) 
4. Roytman A. P. Laboratory markers of heart desease. Maintance in therapy effectiveness: Abst. Diss. Moscow, 2006. (In Russian)

5. Fedorova M. M., Roytmann A. P. Prognastic value of adiponectin as marker of a metabolic syndrome. Laboratory. 2009, no. 1, pp. 9-10. (In Russian)

6. Chernishev A. V. Multi-purpose strategy of preventive maintenance and regenerative treatment of patients by ischemic illness of heart and group of risk: Abst. Diss. Moscow, 2006. (In Russian)

7. Angelo L. Gaffo, Lawrence N. Edward, Kenneth G. Saag. Hyperuricemia and cardiovascular disease: how strong is the evidence for a causal link? Arthritis Research and Therapy. 2009, no. 11, pp. 240 (DOI:10.1186/ar2761).

8. Bentz G. L., Yurochko A. D. Human CMV infection of endothelial cells induces an angiogenic response through viral binding to EGF receptor and beta1 and beta3 integrins. Proc. Natl. Acad. Sci. USA. 2008, no. 105 (14), pp. 5531-5536.

9. Crumpacker C. S. Invited commentary: human cytomegalovirus, inflammation, cardiovascular disease, and mortality. Am. J. Epidemiol. 2010, no. 172 (4), pp. 372-374.

10. Del Rio D., Stewart A. J., Pellegrini N. A review of recent studies on malondialdehyde as toxic molecule and biological marker of oxidative stress. Nutrition, Metabolism and Cardiovascular Diseases. 2005, no. 15, pp. 316-328.

11. Faulhaber-Walter R. Adipokines and central control in adenosine A1 receptor dependent glucose metabolism. Adipocyte. 2012, no. 1 (2), pp. 108-111.

12. Heseler K. Cytomegalovirus impairs the induction of indoleamine 2,3-dioxygenase mediated antimicrobial and immunoregulatory effects in human fibroblasts. Heseler K., Schmidt S. K., Spekker K., Sinzger C., Sorg R. V., Quambusch M., Zimmermann A., Meisel R., Däubener W. PLoS One. 2013, no. 15; 8 (5), p. e64442. 


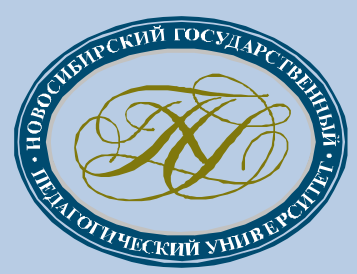

\section{www.vestnik.nspu.ru}

\section{КУЛЬТУРОЛОГИЯ И ИСКУССТВОВЕДЕНИЕ}


Вестник Новосибирского государственного педагогического университета

5(21) $2014 \quad$ www.vestnik.nspu.ru ISSN 2226-3365

(C) Цюй Чуньлэй, E. В. Тихомирова

DOI: $10.15293 / 2226-3365.1405 .16$

УДК 372.016

\title{
ЯЗЫКОВЫЕ РЕПРЕЗЕНТАЦИИ УНИВЕРСАЛИИ СРЕДИННЫЙ ПУТЬ В РУССКОЙ И КИТАЙСКОЙ КУЛЬТУРЕ
}

\begin{abstract}
Цюй Чуньлэй (Шаньдун, Китай), Е. Е. Тихомирова, (Новосибирск, Россия)
В статье авторы обращаются к анализу языковых реализаџий культурной универсалии «срединный путь». Делается попьтка показать, что она является культурной нормой, имеет ключевое значение для понимания базовых ценностей культуры. Применяя когнитивный, семиотический и аксиологический подходы к изучению знаковых явлений в языке и культуре, авторы выявляют глубинные универсальные и начиональные смысль представлений о срединном пути. При этом срединный путь интерпретируется не как усредненность, а как этапь процессов понимания, обеспечивающие синкретичность культуры. Обширный языковой материал русского и китайского языков позволяют авторам сделать выводы, полезные как для теории культуры, так и для лингвокультурологии.
\end{abstract}

Ключевые слова: культура, культурная универсалия, бинарнье оппозиции, культурная норма, концепт, русский язык, китайский язык, этика, модели поведения, срединный путь.

Изучение культурных универсалий позволяет на современном этапе развития межкультурной коммуникации находить те реперы, которые позволяют обеспечить взаимопонимание и взаимопереводимость культур. Культурные универсалии рассматриваются как основы, инварианты различных культур [4-5; 9; 11], то неизменное, что присутствует в каждой из них: человек, его адекватное действие во времени и пространстве и окружающий мир. Инвариантом является тождество между человеком и миром. Культура есть способ отождествления человека и мира, их согласованный порядок, делающий возможным воспроизводить человека как биологическое, социальное и культурное существо. Культура в то же время есть смыслы человеческой деятельности. Система универсалий культуры образует словарь со своими парадигматическими и синтагматическими правилами, дает варианты национальных образных репрезентаций. Одной из важнейших универсалий этого словаря является универсалия nуmь [12-13].

Цюй Чуньлэй - студентка, Шаньдунский педагогический университет, КНР.

E-mail: 1169128487@qq.com

Тихомирова Елена Евгеньевна - кандидат культурологии, доцент кафедры теории, истории культуры и музеологии, Новосибирский государственный педагогический университет; докторант, Российский государственный гуманитарный университет.

E-mail: imktikhomirova@mail.ru 
Вестник Новосибирского государственного педагогического университета

5(21)2014 www.vestnik.nspu.ru

ISSN 2226-3365

Своеобразие срединного пути, с одной стороны, заключается в своеобразии русского и китайского национального характера и особенностях воплощения в нем представлений о срединном пути и связанных с ним моделей поведения, с другой стороны, в особенностях геополитического и культурного положения России и Китая и формировании на их основе серединных культур.

Д. С. Лихачев отмечает национальное своеобразие действий русского человека: «...во всем доходить до крайностей, до пределов возможного, и при этом в кратчайшие сроки. Не только в пресловутых русских внезапных отказах от всех земных благ, но и в русской философии и искусстве» [7, с. 16]. Вспоминаются в связи с этим слова Иисуса Христа: «...Знаю твои дела; ты ни холоден, ни горяч; о, если бы ты был холоден, или горяч! Но, как ты тепл, а не горяч и не холоден, то извергну тебя из уст Моих» [Откр. 3:1418]. Христианская культура требовала активной жизненной позиции. В традициях Древней Руси было уважение к другому человеку, особенно к старшему, более опытному, более пережившему, уважение и бережное отношение ко всему живому; умение стойко переносить тягости и превратности судьбы; терпимость, доброжелательность, бескорыстие. В. И. Даль в тематическом делении пословицы русского народа очень точно использует бинарные оппозиции. Бинарная оппозиция - это универсальное средство членения мира, способ подачи информации о мире человеческим сознанием. Маркирование границ бинарной оппозиции - это, возможно, обозначение границ мира, причем в разных плоскостях. Универсальная структура мифологического мира представлена пространствами: мир богов мир живых - мир мертвых, воплощенная в мировом древе, языковой и культурной универсалии верх - середина - низ по вертикали и право - середина - лево по горизонтали. В этой традиции человек является центром системы координат. Середина - это промежуток, промежуточное положение. Бинарная оппозиция представляет собой границы культурной нормы можно - нельзя, в том числе, границы нормы поведения: Не все должно, что можно. Он выделяет разделы пословичного фонда: строгость - кротость; прямота - лукавство; воля - неволя; друг - недруг; умеренность - жадность; простор - теснота; гульба - пьянство. При этом он видит, что бинарная оппозиция не только противопоставляет, но и объединяет, выстраивает границы явления, например, осторожность - смирение. Смирение является одной из важнейших христианских добродетелей. Но и здесь В. И. Даль фиксирует бинаризм не как противопоставление, а как крайние члены, отрицательно маркированные: Живи тихо, не увидишь лиха. - Новгородизы такали, да Новгород протакали. - Кто живет тихо, тому лихо. - Тихомирныий под спудом жсивет. - Тиха вода, да от нее потоп живет. - С краю не ложатся, а все в середину [2, с. 207-208]. Здесь представляется важным провести параллель, касающуюся этического статуса средины в европейской культуре. Так, Аристотель помещает все человеческие добродетели между крайностями, пороками. У него середина присутствует везде: «Среднее есть начало и конец - начало последующего и конец первого» («Физика»VIII 8, 262 а 20-25). Интересно, что и у В. И. Даля находим такие ряды: богатство - достаток - убожество; пора - мера - спех; кара - милость - потачка; кара - признание - покорность; задор гульба - беспутство; мир - ссора - спор; смелость - отвага - трусость, правда - неправда - ложь.

Своеобразие срединного пути, с одной стороны, заключается в своеобразии русского 
и китайского национального характера и особенностях воплощения в нем представлений о срединном пути и связанных с ним моделей поведения, с другой стороны, в особенностях геополитического и культурного положения России и Китая и формировании на их основе серединных культур [10-11, 14-17].

С западноцентристской точки зрения А. Вежбицкая пытается интерпретировать подобные оценочные ряды как «склонность к отрицательным оценкам» [1, с. 95], с точки зрения русского человека сниженную эмоциональность англичанина в купе с его толерантностью можно рассматривать как безразличие.

Одной из известных черт русского человека всегда является особое отношение, любовь к своей земле, Родине, дому. Дом представляется центром мира, дом как граница своего далее раздвигается: двор - улица село - край - бельий свет. Всегда русский человек осознавал свою связь с миром людей и с окружающим миром, с природой. В русском фольклоре воплощен идеал жизни, мечты о всеобщем счастье, о жизни «по правде». Нравственно маркированное представление о пути, жизненном пути, крестном пути как представление о правильности в противоположность кривде, лукавости, т. е. пре-стуnлению, локализуется у русского человека в сердие. Оно «...нравственно, оно есть представитель любви, воли, страсти, нравственного, духовного начала, противоположно умственному, разуму, мозгу» [3, с. 174].

Толкование срединного пути в русских моделях поведения достаточно часто сводятся к разговору о посредственности, которая толкуется у В. И. Даля «ни мал, ни велик, или ни худ, ни хорош» [3, с. 174]. Этот семантический ряд с явно отрицательными коннотациями дополняют и дериваты с оценочными семами: середнячок, серединка, серёдка, усреднение, средненький, усреднённый, усреднять, средне, среди, в среднем. Русское слово посредственный может восприниматься как нечто находящееся посредине, ни то, ни се; но уже в современном русском языке возникает слово посреднический, т. е. содействующий в переговорах конфликтуюшим сторонам в решении спорных вопросов кто в состоянии вступать в обоюдное взаимодействие. Эта ценность в русской культуре кодируется представлением о ладе, улажсивании, прилажсивании и т. д. Положительными оценочными коннотациями маркировано и слово сердиевина, в переносном значении важнейшая часть чего-либо; основа, сущность чего-либо.

Таким образом, в середине обнаруживается ее принадлежность к зоне перехода, границе. Поэтому пограничность оказывается тем состоянием, которое маркирует Россию как срединное государство, для которого важным является представление о меже границе - рубеже - заставе между Европой и Азией. Ю. М. Лотман предлагает рассматривать идею «срединной культуры» предлагая концепцию бинарности-тернарности культур: «Усиление интенсивности семиотических процессов в пограничной полосе семиосферы связано с тем, что именно здесь происходят постоянные вторжения в нее извне. Граница, как мы уже сказали, двусторонняя, и одна сторона ее всегда обращена во внешнее пространство. Более того, граница - это область конституированной билингвиальности. Это получает, как правило, и прямое выражение в языковой практике населения на границе культурных ареалов. Поскольку граница необходимая часть семиосферы и никакое “мы” не может существовать, если отсутствуют “они”, культура создает не только свой тип внутренней организации, но и свой тип внешней “дезорганизации”. В этом смыс- 
ле можно сказать, что “варвар” создан цивилизацией и так же нуждается в ней, как и она в нем. Внешнее запредельное пространство семиосферы - место непрерывающегося диалога. Безразлично, видит ли данная культура в “варваре" спасителя или врага, носителя здоровых моральных качеств или развращенного каннибала, она имеет дело с конструктом, построенным как ее собственное перевернутое отражение» [8, с. 267]. Далее Ю. М. Лотман приводит пример волн понимания, синкретичности в культуре во времени и пространстве бинарной оппозиции свой - чужой: язычники, погани (чужие)- свои погани (язычники, живущие на границе с русской стороны) - свой (христианин). Так появляется идея евразийства.

И. В. Кондаков отмечает: «За каждым бинарным фреймом в истории русской культуры встает в явной или имплицитной форме изначальная культурная дихотомия Запада и Востока, символизирующая причастность России и русской культуры как тому, так и другому, т. е. всему человечеству, мировой культуре и цивилизации, притязания на принципиальную “всемирность”, “всеохватность”, вселенский масштаб» [5, с. 98].

Представление же о серединном пути кодирует практически все культуры, а в китайской культуре является стержневой. Тексты даются в переводе одного из соавторов этой статьи, т. е. отражают современные ассоциативные ряды и интерпретации традиционных классических текстов, что дает возможность, с одной стороны, выявить глубинные смыслы, транслирующиеся до сих пор, а, с другой, их деформацию и приращение новыми смыслами.

В китайской культуре термин срединный nуть (中庸之道) имеет синоним [6] - 不 偏不倚 - не отклоняться ни в ту, ни в другую сторону, и антонимы - 厚此薄彼 - одно ие- нить, а другим пренебрегать; 偏听偏信 прислушиваться $\kappa$ мнению только одной стороны и принимать его на веру.

Идея срединного пути является одним из основных элементов общей культурной и общественной психологии и ключевым понятием в учении конфуцианства. Неоценимую роль в развитии национальной культуры играет конфуцианский философский трактат «Учение о срединном и неизменном пути», «Срединное и неизменное», «Учение о середине» (中庸 - Чжун Юн), приписываемый традицией внуку Конфуция Цзы Сы (ок. 483402 до н. э.), который пытался решить социальные проблемы для достижения гармонии в обществе. В книге «Китайское духовное наставление» (中华 心 法) первое значение: « 中不偏, 庸不易》, именно такой: у каждого должна быть праведная жизнь и устойчивые цели и идеи, для того, чтобы добиться успеха. Конфуций сказал: «中庸之为德也, 其至矣乎! 民鲜久矣》. (Как и моральная этика, срединный путь должен быть наиболее высокий, и этого людям не хватает уже долго). Второе значение: надо жить справедливо и спокойно. Если не получается - значит, человек слишком эмоционален. Третье значение: «中 (zhōng)»-хороший, «庸 (yōng)»-nолезный. « 中庸(zhōng yōng)» значит толковый и стоящий. Человек должен уметь делать чтонибудь хорошо. Еще есть такое значение: надо идти к своей цели и нести ответственность за свои поступки. Конфуций впервые выдвинул учение о срединном пути, которое, дополнившись мыслями китайских мудрецов, стало важным моральным учением. Чжу Си (1130-1200) - мыслитель и философ, главный представитель неоконфуцианства - писал, что 中庸者,不偏不倚,无过不及,看似平常之理, 实则精妙至极. (Идея срединного пути заключается в следующих словах: «совершенный, 
тонкий; искусный и мастерский»). Идеология срединного пути изменяется постоянно. Изменение и есть жизнь идеи. Срединный путь не несет в себе идеи простого нейтралитета или недеяния, и тем более, безучастного отношения к другим, а уделяет большое внимание человеческой инициативе. Она акцентирует внимание на том, что не нужно слишком показывать себя, но надо действовать, исходя из своих возможностей. Не нужно быть слишком принципиальным, но надо соответствовать изменяющимся условиям окружающей среды, надо учитывать место, время, обстоятельства и личностный фактор. Надо приспосабливаться к обстоятельствам и действовать в соответствии со сложившейся ситуацией. Нужно уметь проявлять личную инициативу, чтобы анализировать и разрешать реально существующие проблемы. Необходимо анализировать ситуацию, держать ее под контролем, или в нужное время пользоваться ей для того, чтобы делать добро.

В современном словаре «Синьхуа» написано, что срединный путь - это не эклектика. Эклектика беспринципно приравняет две стороны конфликта, не отличает правду ото лжи. Её духовная сущность: в то время, когда управляешь отношениями между людьми и решаешь социальные проблемы, нужно думать над вопросом полностью и не впадать в крайности. Нужно быть благодушным, чтобы сохранять стабильность отношений между людьми и жить в дружбе и согласии. Рассматривать её как эклектику - не адекватно понимать смысл срединного пути [18]. В книге «Лунь Юй» Конфуций поощряет 和而不同, т. е. следует ладить со средой, но не отождествляться с ней, выступает против 同而不, т. е. не следует отожествляться со средой, но не соответствовать ей. Срединный путь играет необычайно важную роль в китайской истории философии. Конфуций под- разумевает 中(zhōng) - срединный как 无过无 不; это предполагает, что следует уметь вести себя в обществе и хорошо обходиться с людьми и делать как раз то, что нужно. Срединный путь представляет собой единство нравственности и добродетели. Для современного воспитания культуры и нравственности он имеет огромное значение.

С точки зрения человека и природы, срединный путь требует гармонии между человеком и природой. Чжуан Цзы (4-3 вв. до н. э.) - один из основоположников даосизма, впервые выдвинул учение о единстве природы и человека (天人合), которое говорит о гармонии между людьми и природой. Срединный путь составляет единство природы и человека.

Срединный путь - это равновесие. Конфуций даёт определение срединного пути как «执两用中», что можно перевести как поддерживать обе сторонь, держаться середины и «过犹不及》-кто-то перестарается, a кто-то недоделает. Это означает: не нужно переусердствовать. Все в мире противоречиво. В идеале нужно найти центр противоречия и попытаться его урегулировать. И это - срединный путь. Из-за пристрастного отношения будет обостряться противоречие, и дело будет значительно сложнее держать под контролем.

Срединный путь уравновешенный и положительный. В книге «Срединный путь» написано, что требуется любить других так же, как любишь себя, а обвинять других так же, как винишь себя. Наставлять и вдохновлять человека с искренностью и снисходительностью, чтобы сохранять мирное сосуществование. Основные принципы состоят в следующем.

Нужно быть осторожным и в словах, и в поступках, и заниматься самообразованием. В процессе самосовершенствования надо 
настаивать на самообразовании и самоограничении, учиться самоконтролю. В книге Цзы Сы говорится: надо строго и сознательно заниматься самообразованием, особенно индивидуально. Нужно быть великодушным и благодушным. Необходимо ставить себя на место другого, понимать, заботиться, быть преданным и великодушным. Необходимо быть искренним настолько, насколько это возможно. Должно отстаивать принцип, чтобы выявить свое сердечное естество и потом выявить чужое сердечное естество и после этого выявить сердечное естество всего сущего, и, наконец, достичь степени совершенного и самого гуманного. Так человек может найти свое настоящее положение в мире.

Кроме этого существует еще ряд принципов, например, доверять друг другу, быть честным и добрым и т. д.

Содержание срединного пути заключает в себя такие основные смыслы, как 五达道 (wǔ dá dào), 三达德 (sān dá dé), 九经 (jiǔ jīng).

五达道 - использование срединного пути для регулирования пяти видов отношений между людьми. Это отношения типа: гуманный государь и преданный слуга, любящий отец и послушный сын, муж и жена, братья и друзья. Они являются переходными отношениями в мире. Если правильно поддерживать эти отношения, можно достичь высшей степени добродетели.

三达德 - разум, человеколюбие и справедливость, смелость. Эти качества могут использоваться в отношении между людьми с помощью честности и доброты.

九经 - девять правил (законов), обеспечивающих порядок в государстве. Это самообразование, уважение к человеку высокой морали, любовь к родственникам, уважение к министрам, умение входить в положение министров, умение беречь народные массы, поощрять ремесленников, хорошо обходиться с гостями и успокаивать феодалов. Если соблюдать эти правила, то порядок в государстве будет обеспечен. Как говорится в книге 《尚书» («Шан Шу», «Книга преданий») - одном из наиболее почитаемых древнекитайских памятников, входящих в конфуцианский свод классической литературы «Тринадцать канонов», приписываемый Конфуцию: «克明俊德, 以亲九族,九族既睦,平章百姓, 百姓昭明,协和 万邦》。

Конфуцианская культура считает, что 水止于平而止; 道至于中庸中而止.所以君子尊 德性而道问学;致广大而尽精微, 极高明而道中 庸 - вода должна стать спокойной, когда она не течет, путь должен прекратиться, когда он доходит до срединного пути, поэтому благородный человек уважает нравственную натуру, через вопрошание совета, он сам учится, чтобы знания были не только широкими, но и утонченными, чтобы нравственность могла следовать срединному пути [7]. Срединный путь - наивысшая китайская духовная идея и верховный кодекс поведения. Если вещь хочет стать идеальной и сохранять индивидуальное, то ей надо двигаться в подходящее время и место и с подходящим пределом, именно держать умеренно, чтобы стремиться к наилучшему положению, это единство природы и человека (天人合).

В конфуцианском учении у срединного пути есть разные степени, и наивысшая степень - единство природы и человека. Чтобы реализовать цель срединного пути, надо учиться, усваивать знания и соблюдать принцип срединного пути, а не роптать на небо, питать злобу к людям, и винить других (怨天 尤人), ясность и мудрость обладающего разумом ограждает его от зла.

Проявление единства природы и человека в срединном пути в следующих областях: единство пути бога и человека, един- 
ство характера бога и человека, единство разума и чувств, сверхъестественные силы и святого человека, единство внешнего и внутреннего.

Путь бога - чистосердечие, путь человека - стремиться к чистосердечию. Стараться именно совместить эти два пути. Любой человек может достичь наилучшего и совершенного, если будет продолжительно учиться.

Характер бога - высшая доброта, искренность, гуманность, человеколюбие. Характер человека должен быть вышей добротой, искренностью, гуманностью, человеколюбием. Поэтому нужно хорошо знать закон. Радость, гнев, грусть и веселье - выражение чувств, надо сдерживать и ограничивать чувства и следовать срединному пути, чтобы реализовать единство природы и человека. В книге Цзы Сы можно прочитать: «喜怒哀乐之 未发谓之中, 发而皆中节谓之和》。
Сверхъестественные силы - общее название мира и предков, святой человек высоконравственный человек, надо стать чистосердечным и с уважением относиться к природе. Можно считать, что единство поступка и морали, или знания и действия.

В целом, надо начать изучать тонкости дела и потом внимательно взвешивать, искать оптимальный результат, отличный от крайностей.

Размышления над культурной универсалией срединный путь демонстрирует, что в таких отдаленных территориально и ментально культурах как русская и китайская вычленяются необходимость адекватных действий человека во времени и пространстве: во-первых, по отношению к своей биологической природе; во-вторых, социальном и культурном плане, в отношениях между людьми, между человеком и природой.

\section{СПИСОК ЛИТЕРАТУРЫ}

1. Вежбицкая А. Язык. Культура. Познание. - М.: Русские словари, 1996. - 416 с.

2. Даль В. И. Пословицы русского народа. - М.: Русский язык, 2009. - 814 с.

3. Даль В. И. Толковый словарь живого великорусского языка: в 4 тт. - Т. ІІІ. - СПб.: Диамант, 1996. - 664 с.

4. Евзрезов Д. В., Майер Б. О. Проблемы образования и когнитивная философия: анализ категорий «паттерн» и «метапаттерн» // Философия образования. - 2006. - № 3. - С. 63-70.

5. Кондаков И. В. Русская культура: краткий очерк истории и теории. - М.,1998. - 582 с.

6. Конфуцианский трактат «Чжун Юн»: переводы и исследования / Сост. А. Е. Лукьянов; отв. ред. М. Л. Титаренко. - М., 2003.

7. Лихачёв Д. С. Книга беспокойств: Статьи, беседы, воспоминания. - М.: Новости, 1991. - 528 с.

8. Лотман Ю. М. Семиосфера. - СПб.: Искусство-СПБ, 2000. - 703 с.

9. Майер Б.О. О паттерне «double bind» в современном обществе и образовании // Вестник Новосибирского государственного педагогического университета - 2012. - № 3. - С. 44-55.

10. Мартыненко Н. П. Специфика семиотического изучения древнекитайских текстов. - М. : Изд-во МГУ, 2007. - 372 с.

11. Неретина С. С., Огурцов А. П. Пути к универсалиям. - С-Пб.: РХГА, 2006. - 999 с.

12. Тихомирова Е. Е., Абенова Г. Э., Линь Хай. Языковые реализации культурной универсалии «путь» в русском и китайском языках // Вестник Новосибирского государственного педагогического университета. - 2012. - № 6. - С. 51-62. 
13. Тихомирова Е. Е., Линь Хай. Этические коннотации культурной универсалии «путь» в русском и китайском языках // Вестник Новосибирского государственного педагогического университета. - 2013. - № 3 - С. 100-105.

14. Тихомирова Е.Е., Чжао Цзиннань Когда жилище становится домом: универсальные культурные смыслы китайской традиции // Вестник Новосибирского государственного педагогического университета. - 2012. - № 3. - С. 98-103.

15. Универсалии восточных культур. Отв. ред. Степанянц М. Т. - М.: Издательская фирма "Восточная литература" РАН, 2001. - 431 с.

16. Hajime Nakamura. Ways of Thinking of Eastern Peoples: India-China-Tibet-Japan. Revised English translation edited by Philip P. Wiener. - Honolulu, 1964. - $712 \mathrm{p}$.

17. The Chinese Mind. Essentials of Chinese Philosophy and Culture; The Indian Mind. Essentials of Indian Philosophy and Culture; The Japanese Mind. Essentials of Japanese Philosophy and Culture. (Ed.) by Charles A.Moore. - Honolulu, 1967. - 652 p.

18. Xinhua zidian. Толковый словарь китайского языка (На китайском). - Beijing, 2004. - 908 р. 
DOI: $10.15293 / 2226-3365.1405 .16$

Qu Chunlei, Student, Shandong Pedagogical University, Shandong, People's Republic of China.

E-mail: 1169128487@qq.com

Tikhomirova Elena Evgenyevna, Candidate of Cultural Sciences, Associate Professor of the Department of the Theory, Cultural History and Museology, Novosibirsk State Pedagogical University, Novosibirsk, Russian Federation.; Doctoral Candidate, Russian State Humanitarian University, St. Petersburg, Russian Federation.

E-mail: imktikhomirova@mail.ru

\title{
LANGUAGE REPRESENTATION OF THE UNIVERSAL MIDDLE PATH IN THE RUSSIAN AND CHINESE CULTURE
}

\begin{abstract}
In the article authors address to the analysis of language realization of a cultural universal "median way". Attempt to show becomes that it is cultural norm, has key value for understanding of basic values of culture. Applying cognitive, semiotics and axiological approaches to studying of the sign phenomena in language and culture, authors reveal deep universal and national meanings of ideas of a median way. Thus, the median way is interpreted not as averaging, and as stages of processes of the understanding, cultures providing a syncretism. Extensive language material of the Russian and Chinese languages allow authors to draw the conclusions useful both to the theory of culture, and for cultural linguistics.
\end{abstract}

\section{Keywords}

culture, cultural universal, binary oppositions, cultural norm, concept, Russian, Chinese, ethics, behavior models, middle path

\section{REFERENCES}

1. Verbitskaya A. Language. Culture. Cognition. Moscow: Russian dictionaries Publ., 1996. 416 p. (In Russian)

2. Dahl C. I. Proverbs of the Russian people. Moscow: Russian language Publ., 2009. 814 p. (In Russian)

3. Dahl C. I. Explanatory dictionary of the live great Russian language: 4 vol., St. Petersburg: Diamond Publ., 1996. Vol. 3, 664 p. (In Russian)

4. Evzrezov D.V., Mayer B. O. Problems of education and cognitive philosophy: an analysis of the categories of "pattern" and "metapattern". Philosophy of Education, 2006, no. 3, pp. 63-70. (In Russian)

5. Kondakov I. Century Russian culture: a brief sketch of the history and theory. Moscow, 1998. 582 p. (In Russian)

6. Confucian treatise "Zhong Yong”: Translations and studies. (eds.) A. E. Lukyanov, M. L. Titarenko. Moscow, 2003. (In Russian)

7. Likhachev D. C. Book concerns: Articles, conversations, memories. Moscow: News Publ., 1991. 528 p. (In Russian) 
8. Lotman Y. M. Semi. St. Petersburg: Art-SPB Publ., 2000. 703 p. (In Russian)

9. Mayer B.O. About the pattern «double bind» in modern society and education. Novosibirsk State Pedagogical University Bulletin, 2012, no. 3, pp. 44-55. (In Russian)

10. Martynenko N. P. Specificity semiotic study of ancient Chinese texts. Moscow: Publishing house of Moscow State University, 2007. 372 p. (In Russian)

11. Neretina, S. C., Ogurtscov A.P. The way to universals. SPb.: RHGA Publ., 2006. 999 p. (In Russian)

12. Tikhomirova E. E., Abenova, E., Lin Hai. Language implementation of cultural universals "path” in Russian and Chinese languages. Novosibirsk State Pedagogical University Bulletin, 2012, no. 6, pp. 51-62. (In Russian)

13. Tikhomirova E. E., Lin Hai. Ethical connotations of cultural universals "path" in Russian and Chinese languages. Novosibirsk State Pedagogical University Bulletin, 2013, no. 3, pp. 100105. (In Russian)

14. Tikhomirova E. E., Zhao Jingnan When the housing becomes the house: universal cultural senses of the Chinese tradition. Novosibirsk State Pedagogical University Bulletin, 2012, no. 3, pp. 98-103. (In Russian)

15. Universal Eastern cultures. (ed.) Stepanyants M. T. Moscow: Publishing house Vostochnaya Literatura RAS, 2001. 431 p. (In Russian)

16. Hajime Nakamura. Ways of Thinking of Eastern Peoples: India-China-Tibet-Japan. Revised English translation edited by Philip P. Wiener. Honolulu, 1964. 712 p.

17. The Chinese Mind. Essentials of Chinese Philosophy and Culture; The Indian Mind. Essentials of Indian Philosophy and Culture; The Japanese Mind. Essentials of Japanese Philosophy and Culture. (Ed.) Charles A.Moore. Honolulu, 1967. 652 p.

18. Xinhua Zidian. Explanatory dictionary of the Chinese language (Chinese). Beijing, 2004. 908 p. (In Chinese) 


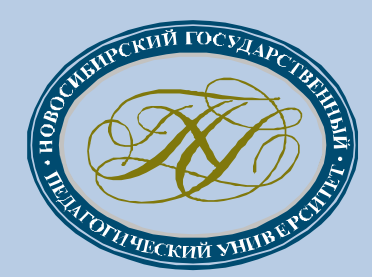

\section{www.vestnik.nspu.ru}




\title{
УДК 801.161.10
}

\section{АНАЛИЗ ОСНОВНЫХ КОММУНИКАТИВНЫХ МОДЕЛЕЙ РОССИЙСКОГО И КИТАЙСКОГО БИЗНЕС-ДИСКУРСОВ}

\author{
О. В. Бычихина (Новосибирск, Россия)
}

В статье автор делает попытку проанализировать языковые и экстралингвистические особенности ведения бизнес-коммуникации представителями китайской и российской сторон. Цель статьи - выделить и охарактеризовать основные коммуникативные модели российского и китайского бизнес-дискурсов. Говорится, что одним из проявлений активных динамических прочессов, произошедших в языке за последнее время, является изменение стратегий ведения коммуникации, в том числе и бизнес-коммуникации. Актуальность темы обусловлена тем, что экономические успехи Китая в последнее время стали наиболее очевидны. Бизнесмены из многих стран мира, в том числе из России, стремятся наладить доверительнье деловые отношения с китайцами, следовательно, знание смысловых особенностей построения китайской и российской бизнес-коммуникации позволяет избежать многих ошибок, предотвращает напряженность и недопонимание в отношениях между деловыми партнерами. Особое внимание уделяется сравнительному анализу использования традиционных китайских и российских коммуникациионых моделей.

Китайский и российский подходы к ведению бизнес-переговоров сравниваются по различным критериям, таким как: интонация, цуель коммуникации, доминанты коммуникации, основной источник информации, стратегии ведения бизнеса, особенности коммуникации и язьковые средства. Отдельно вылеляются основные языковые средства выражения прямых и косвенных речевых жанров с семантикой отказа.

Ключевые слова: теория речевых жанров, прямой/косвенный речевой жанр, способы выражения отказа, модусные показатели, персуазивность, активные процессы в русском языке, бизнес-переговоры, деловая культура, коммуникационные модели.

В настоящей статье предпринята попытка проанализировать языковые и экстралингвистические особенности ведения бизнеса китайскими и российскими партнерами. Эта тема была вызвана двухгодичным пребыванием автора в Китае в качестве преподавателя русского языка как иностранного сту- дентам, в том числе, факультета бизнеса и туризма и наблюдением за основными речевыми стратегиями при ведении переговоров с российскими партнёрами. Особое внимание уделяется сравнительному анализу использования традиционных китайских и российских коммуникационных моделей.

Бычихина Ольга Владимировна - кандидат филологических наук, доцент кафедры русского языка и восточных языков Сибирского государственного университета путей сообщения.

E-mail: bychikhina.olga@yandex.ru 
По мнению Л. Грузбер и И.Б. Новика, свойство языка вступать со средой во многосторонние и разнообразные (взаимокоррелирующие) отношения - одно из основных его особенностей как сложной динамической системы $[7,11]$. Бесспорно, язык вообще и русский язык, в частности, служит отображением все того, что происходит в среде, обществе. Многие процессы (развитие систем телекоммуникации, политические события в России, её отношения со странами ЕС и Востока и др.) за последнее время оказали огромное влияние на революционное преобразование русского языка, на появление в нем активных процессов. На данный момент выделяют такие активные процессы в русском языке, как изменения в условиях функционирования языка, в построении текста, в системе языка [1-3, 12, 14-15.]. Наиболее явными среди активных процессов, происходящих в языке, являются условия функционирования языка ${ }^{1}$. Изменение условий функционирования языка, его активное «вторжение» в сферу бизнес-коммуникации (особенно деловых отношений между Китаем и Россией) не могло не сказаться на особенностях построения вербальной и невербальной коммуникации.

Актуальность темы обусловлена тем, что экономические успехи Китая за последние 30 лет стали очевидны всему мировому сообществу. Многие авторитетные исследователи (Игорь Панарин, профессор Дипломатической академии МИДа России; Гидеон Рахман, Financial Times ${ }^{2}$, Збигнев Бжезин-

${ }^{1}$ Активные процессы в русском языке на современном этапе [Электронный ресурс]. - URL: - $\quad$ http://www.nado5.ru/e-book/aktivnyeprocessy-v-russkom-yazyke (дата обращения: 11.10.2013).

${ }^{2}$ США и Китай: какие преимущества и недостатки двух мощных держав нашего времени? [Электронный pecypc]. - URL: - ский, руководитель Центра стратегических и международных исследований (CSIS) ${ }^{3}$ и др.) считают, что в XXI веке нас ждет наступление «века Азии», и прежде всего, поднимающегося гиганта - Китая. Все эксперты признает его мощь и называет будущим преемником Америки, а многие даже считают, что Китай сможет стать новой сверхдержавой, подмяв под себя США. По сообщениям многих источников, за последние пять лет в году экономика Китая вышла на первое место и опередила экономику США ${ }^{4}$. Все это еще более повышает интерес к выстраиванию деловых отношений с китайскими бизнеспартнерами.

В этих условиях для того, чтобы стать полноправным партнёром Китая, необходимо знать особенности бизнес-коммуникации покитайски, учитывать особый подход китайцев к ведению бизнеса. Это поможет избежать многих ошибок и предотвратить напряженность и недопонимание, которые могут угрожать деловым отношениям между китайцами и россиянами (沟通的主体 : 关系). Цель данной работы - проанализировать особенности построения китайского способа ведения бизнес-переговоров. Для этого необходимо решить следующие задачи: а) определить понятие слова «переговоры»; б) описать лингви-

http:/www.liveinternet.ru/users/ hercy/ post210230506/ (дата обращения: 11.10.2013).

3 Бжезинский 3. Без США миру грозит хаос. [Электронный pecypc]. - URL: http://www.profi-forex. org/ novostimira/novosti_ameriki/usa/entry 1008107089. html (дата обращения: 11.10.2013).

${ }^{4}$ Курцев А. Китай вышел на первое место по темпам роста экономики [Электронный ресурс]. - URL: http://www.sravni.ru/novost/2010/10/5/ kitay-vyshel-na-pervoe-mesto-v-mire-potempam-rosta-ekonomiki/ (дата обращения: 11.10.2013). 
стические и экстралингвистические особенности построения деловой коммуникации в Китае; в) проанализировать языковые способы выражения отказа в китайской бизнескоммуникации - 语言的沟通: 办法。分析 ( 没有）建议是为了研究对语言的理解。

Для начала определим понятие слова «переговоры» (谈判). Концепция, структура построения и ведения переговоров была привнесена в китайскую культуру из-за рубежа. Фактически в традиционном китайском языке отсутствует само слово «переговоры». Термин 谈判 (tánpàn), который используется для этого, представляет собой западное понятие. Это сочетание двух иероглифов - 谈(tán) «обсуждение»（讨论, 硅商）, и 判 (pàn) «суждение» (讨论, 观点). Основная смысловая нагрузка при этом приходится на первый иероглиф 谈(tán) «обсуждение».

Во-первых, стоит отметить, что смысловое наполнение слова 谈判 (tánpàn) в китайском языке кардинально отличается от русского слова «переговоры».

В Китае в понятии «переговоры» актуализируется компонент «толковать», «»разговаривать», тогда как в русском языке на первый план выходят семы «деловая цеель», «обмен мнениями», «соглашение», «договор». Сp.:

ПЕРЕГОВОРЫ - обмен мнениями для выяснения условий какого-нибудь соглашения ${ }^{5}$.

ПЕРЕГОВОРЫ - 1. Обмен МнеНИями с деловой целью ${ }^{6}$.

5 Переговоры: Толковый словарь русского языка / Под ред. Д.Н. Ушакова [Электронный ресурс]. URL: http://www.onlinedics.ru/slovar/ushakov/p/ peregovory.html (дата обращения: 11.10.2013).

${ }^{6}$ Переговоры: С.И. Ожегов, Н.Ю. Шведова. Толковый словарь современного русского языка [Электронный ресурс]. - URL: http://slovarozhegova.ru/
ПЕРЕГОВОРЫ - 1. Офиน. Обсуждение каких-л. вопросов между официальными сторонами с целью выяснения позиций сторон и заключения возможного договора. 2. Обмен мнениями с целью договориться о чём-л.; разговор. Разг. Разговор по телефону с абонентом другого города или страны ${ }^{7}$.

Во-вторых, следует сказать, что смысловое наполнение слова «обсуждать», 谈(tán), в китайском языке также кардинально отличается от этого слова в русском.

В русском контексте «обсуждать» имеет логический, оценочный смысл, а также сему «беседовать». Ср.: ОБСУДИТь - разобрать, оценить, высказывая свои соображения по поводу чего-н. или чьего-н. поведения, проступка ${ }^{8}$. В китайском же «обсужсать» подразумевает скорее «вести продолжающийся диалог».

Таким образом, если двое китайцев захотят провести переговоры, то они скажут: «Давай потолкуем». По замечанию МингЧжер Чена, этнического китайца, долгое время прожившего на Западе и знакомого с особенностями обоих способов ведения коммуникации [10, с. 162], европейская деловая культура воспринимает коммуникацию лишь как обмен информацией, заканчивающейся после завершения сделки, тогда в Китае это неотъемлемая часть выстраивания деловых отношений.

word.php?wordid=20306 (дата обращения: 11.10.2013).

${ }^{7}$ Переговоры: Большой толковый словарь русского языка / Сост. и гл. ред. С.А. Кузнецов. - URL: http://www.gramota.ru/slovari/dic/?word=\%EF\%E5 \%F0\%E5\%E3\%EE\%E2\%EE\%F0\%FB\&all=x (дата обращения: 11.10.2013).

${ }^{8}$ Обсудить: Толковый словарь русского языка / Под ред. Д.Н. Ушакова [Электронный ресурс]. - URL: http://www.slovopedia.com/3/206/807112.html (дата обращения: 11.10.2013). 


5(21)2014 www.vestnik.nspu.ru ISSN 2226-3365

Кроме этого хотелось бы заметить, что у китайцев существует особый подход к понятию «конкуренция», выражающийся в том, что конкуренция и сотрудничество являются двумя сторонами одной медали, что для европейского бизнесмена просто несовместимо.

Тем не менее, несмотря на кажущийся упрощенный и неформальный подход к веде- нию бизнес-переговоров, китайцы являются очень жесткими «переговорщиками» В чем же отличие китайского способа ведения бизнес-беседы от российского? Мы выделили несколько критериев для сравнения китайского и российского подходов к бизнескоммуникации.

\begin{tabular}{|c|c|c|}
\hline Критерии & $\begin{array}{c}\text { Китайский подход } \\
\text { 中方的意见(zhong fang de yi jian) }\end{array}$ & $\begin{array}{c}\text { Российский подход } \\
\text { 西方的意见(xi fang de yi jian) }\end{array}$ \\
\hline Интонация & Тихая 平淡的语气 (ping dan de yu qi) & Громкая 激动的语气 (ji dong de yu qi) \\
\hline Цель & Пошаговый выигрыш & $\begin{array}{l}\text { Перфекционисткая - «все или ничего» (побе- } \\
\text { дитель забирает все) }\end{array}$ \\
\hline $\begin{array}{l}\text { Доминанты ком- } \\
\text { муникации }\end{array}$ & $\begin{array}{l}\text { Опосредованная, сослагательная,侧面表 } \\
\text { 达 (ce mian biao da) }\end{array}$ & $\begin{array}{l}\text { Прямая, императивная 直接回应 (zhi jie hui } \\
\text { ying) }\end{array}$ \\
\hline $\begin{array}{l}\text { Основной источ- } \\
\text { ник информации }\end{array}$ & $\begin{array}{l}\text { Невербальные средства 动作表达(dong } \\
\text { zuo biao da) }\end{array}$ & $\begin{array}{l}\text { Вербальные средства Вербальные средства 语 } \\
\text { 言表达 (yu yan biao da) }\end{array}$ \\
\hline \multirow{5}{*}{ 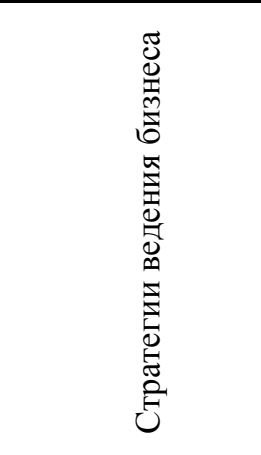 } & $\begin{array}{l}\text { 1. Сохранение лица 对对方有所尊重 (dui } \\
\text { dui fang you suo zun zhong) }\end{array}$ & 1. Искренность, честность \\
\hline & 2. Неопределенность & 2. Определенность \\
\hline & 3. Гибкость и компромисс & $\begin{array}{l}\text { 3. Побеждает сильнейший 对对方不留情面 } \\
\text { (dui dui fang bu liu qing mian) }\end{array}$ \\
\hline & 4. Терпение & 4. Экономия времени (ср.: «Время - деньги») \\
\hline & 5. Социальный статус партнеров & $\begin{array}{l}\text { 5. Непосредственная задача, стоящая перед } \\
\text { партнерами }\end{array}$ \\
\hline \multirow{5}{*}{ 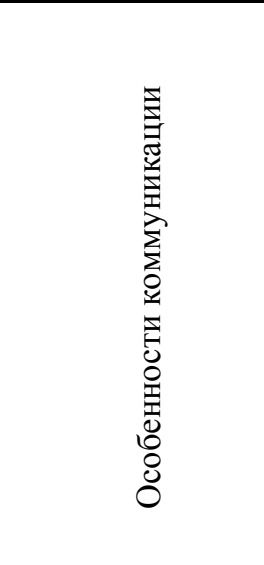 } & $\begin{array}{l}\text { 1. Косвенная, (косвенные высказывания) } \\
\text { - 间接传的达信息/委婉的表达 (wei wan } \\
\text { de biao da) }\end{array}$ & $\begin{array}{l}\text { 1. Прямая коммуникация (прямые высказыва- } \\
\text { ния) - 直接的传达信息/直接的表达 (zhi jie de } \\
\text { biao da) }\end{array}$ \\
\hline & 2. Интровертность, сдержанность & 2. Экстравертность, импульсивность \\
\hline & 3. Личностность & $\begin{array}{l}\text { 3. Обезличенность (командность, корпоратив- } \\
\text { ность) }\end{array}$ \\
\hline & 4. Отсутствие физического контакта & $\begin{array}{l}\text { 4. Наличие, приемлемость физического кон- } \\
\text { такта }\end{array}$ \\
\hline & $\begin{array}{l}\text { 5. Жесты не указывают ни на что, мало } \\
\text { используются }\end{array}$ & 5. Жесты значимы, используются активно \\
\hline \multirow{2}{*}{ 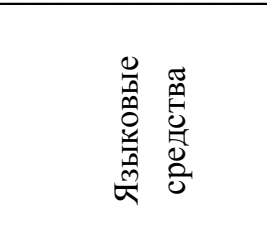 } & $\begin{array}{l}\text { 1. Ясно (понятно) ли я выражаюсь? 我表 } \\
\text { 述的您明白吗 (wo biao shu de nin ming bai } \\
\text { та)? }\end{array}$ & $\begin{array}{l}\text { 1. Bbi меня понимаете? 你明白我的意思吗 (ni } \\
\text { ming bai wo de yi si ma)? }\end{array}$ \\
\hline & $\begin{array}{l}\text { 2. Не затруднит ли вас (не могли бы вы) } \\
\text { сделать это позже? }\end{array}$ & $\begin{array}{l}\text { 2. Не делайте этого (прекратите это де- } \\
\text { лать) }\end{array}$ \\
\hline
\end{tabular}


Вестник Новосибирского государственного педагогического университета

5(21)2014 www.vestnik.nspu.ru ISSN 2226-3365

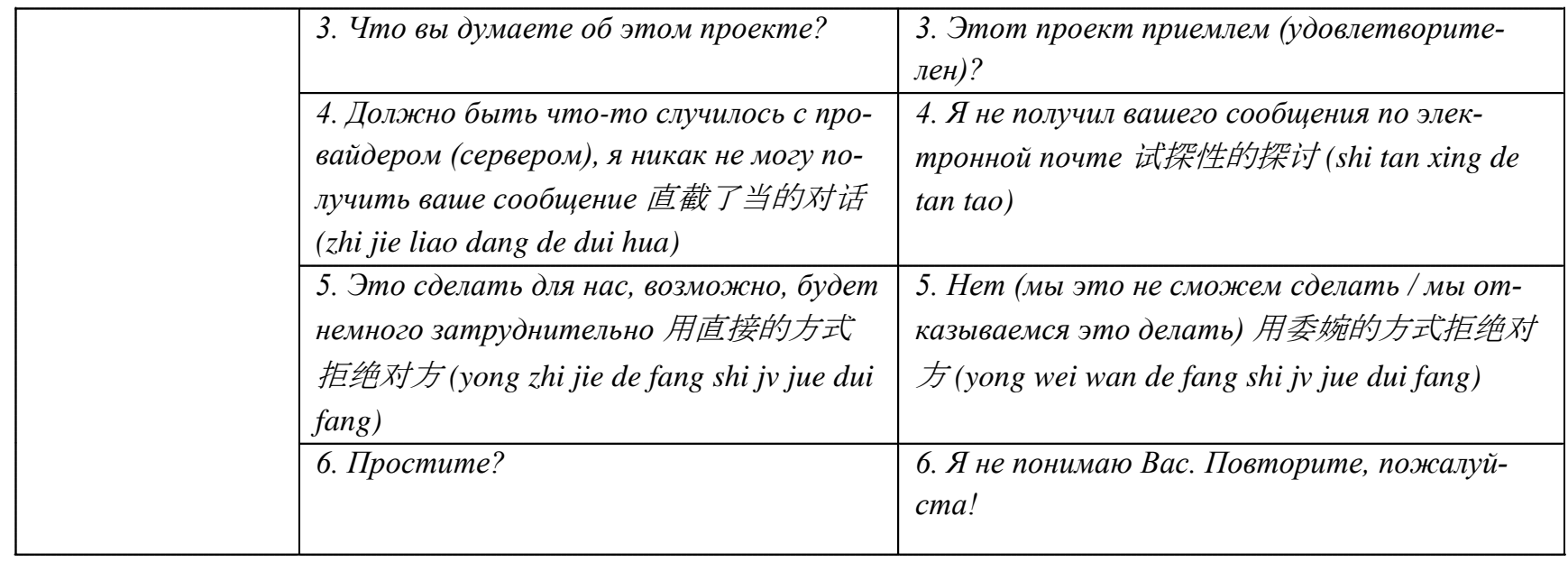

В доминантах коммуникации мы выделили для китайской стороны понятие опосредованной коммуникации. Что же такое опосредованная коммуникация для китайцев? Опосредованность китайской коммуникации заключается в том, что принцип защиты достоинства, лица и уважения социальных ролей вынуждает китайцев выбирать вводные конструкции неопределенной модальности «может быть», «наверное», «скорее всего» и т.д. Они предполагают, что в силу условий коммуникации собеседник верно проинтерпретирует основной смысл информации. При этом правдивость и откровенность коммуникации ничего не значат по сравнению с сохранением коммуникативного баланса. Поэтому очень часто можно услышать «да», а наблюдать поступки, будто было произнесено «нет».

Если говорить о грамматике китайского языка, то она, напротив, является более «непосредственной», чем русская, поскольку в ней отсутствует грамматическая структура сослагательного наклонения. Иными словами, модальность, противоречащая фактам. Здесь нет форм типа «если бы Вы смогли снизить закупочную иену на 1000 юаней, мы бы заключили контракт». Следовательно, для того, чтобы коммуникация прошла без помех, следует избегать предложений с условной модальностью, высказывание должно отражать реальное положение дел. Нужно просто в деталях рассказать, что необходимо делать: «Снизьте закупочную иену на 1000 юаней, после этого мы заключим контракт».

Особым является и отношение китайцев к способам выражения отказа. В уже упоминавшейся книге Ченг Минг-Джера в главе «Никогда не говори «нет». Коммуникация с китайцами» приведена интересная притча: «B традиционном написании иероглифы располагаются на странице сверху вниз, в то время как в западной системе слова пишутся слева направо... Когда китайцы читают свои традиционные тексты, они кивают головой, как бы говоря: «Да-да». Когда европейць читают, они поводят головой, как бы говоря «Hет-нет»» [10, с. 162].

Согласно китайской традиции при ведении переговоров партнерам никогда нельзя говорить «нет». Исторически китайцам всегда были присущи в большой степени выраженные ощущение самодостаточности и забота о сохранении лица. Китайская философия также вносит вклад в уникальность подхода к ведению бизнес-коммуникации.

Китайская коммуникация привязана к конкретному контексту, высоко контекстна. «Да» или «нет» в ней имеют множество различных значений. Существует мнение, что 
Вестник Новосибирского государственного педагогического университета

5(21)2014 www.vestnik.nspu.ru

ISSN 2226-3365

китайцы никогда не говорят «нет». Ченг Минг-Джер формулирует философский взгляд на способы сказать «нет»: «Было бbl, конечно, преувеличением утверждение, что китайцы никогда не говорят «нет», но это близко к истине. Для китайца сказать «нет» - значит пойти против течения, сплачивающегго других людей вокруг нас и укрепляющего сочииальную сеть, к которой они примыкают. Однако для людей с Запада идея никогда не говорить «нет» кажется чуждой. Их взгляд на мир начинается с права человека на самоутверждение - это обусловлено западной философией. Картезианская практика «радикального сомнения» предполагает отрицание всей Вселенной и принятие принциипа достоверности, основанного на индивидуальном сознании. Франиузский философ Жан Поль Сартр (1905-1980) даже доказывал, что человеческое достоинство и человеческая свобода порождены способностью сказать «нет»» [10, с. 175].

Таким образом, сказать прямое «нет» для китайца - значит поплыть против течения. Если же они имплицитно, прямо откажут в просьбе, то партнер в их глазах потеряет лицо, сохранение которого весьма важно для китайской культуры. Но, с другой стороны, если человек не понимает, чего от него хотят или что у него просят, он должен будет сказать «нет», а это ущемит интересы собеседника. Поэтому в ответ на предложение чаще всего можно услышать «да». Смыслы, содержащиеся в нем, диаметрально противоположны и могут содержать в себе как «нет», так и «да».

«Да» может быть косвенным отказом, эквивалентом «нет»- уклонением от прямого ответа, представленным как сигнал о получении информации («я слышу вас», «я понимаю вас» - 有可能意味着回避（我听说你）或（ 我理解你). С другой стороны, это может быть эксплицированным, полным согласием и синонимично китайскому выражению «даю слово» (我答应). 但该系列的另一端 (是) 这 是相当于中国的（我的话）.

В рамках теории речевых жанров [8] нами было выделено несколько способов выражения косвенного речевого жанра отказа.

1. Использованием модусных показателей персуазивности (неуверенности говорящего в сообщаемой им информации [4-7; 13 , с. 683],): «может быть», «возможно», «вероятно», «наверное». Например, «возможно (мне сложно сказать вам), (что) меня устраивают эти условия».

2. Смена предмета обсуждения. Например, «мы рассмотрим это (позже), а теперь...», «позвольте посмотреть на это глубже, а сейчас...»- 另一种方式, 中方为了 避免直接说否, 就是说笑话。

3. Замена субъективного нежелания/невозможности совершения действия объективной путем ссылки на отказ третьей стороны. Например, «мой руководитель очень консервативен, я не знаю, как он может отнестись к вашему предложению».

Итак, в настоящей работе нами было определено содержание понятия «переговоры», рассмотрены его лингвистические и экстралингвистические особенности, а также проанализированы способы выражения отказа.

Учитывая особенности китайского способа ведения бизнес-переговоров, следует избегать так называемых «закрытых» вопросов, требующих однозначных ответов «да»/ «нет». В любом случае основой для соединения различных культур всегда является надежный способ - выстраивать и поддерживать настоящие длительные доверительные партнерские отношения.

«Кстати, сегодня китайцы чаще всего пишут не сверху вниз, а слева направо» [10, c. 182]. 


\section{СПИСОК ЛИТЕРАТУРЫ}

1. Баранчеева Е. И. Особенности вербализации процессов памяти: лексикографические рамки и дискурсивная репрезентация // Вестник Новосибирского государственного педагогического университета. - 2014. - № 4. - C. 114-67. DOI: http://dx.doi.org/10.15293/22263365.1404.11

2. Басалаева Е. Г. О некоторых особенностях становления одоративной метафорической микросистемы русского языка // Сибирский филологический журнал. - 2011. - № 4. - С. 192-199.

3. Басалаева Е. Г., Бокарева Ю. М. Языковые средства манипулирования в дискурсе представителей сетевого маркетинга // Дискурс лжи и ложь как дискурс: Межвузовский сборник научных трудов / Под ред. Т. А. Трипольской. - Новосибирск: Изд. НГПУ, 2012. C. $154-164$.

4. Бычихина О. В. Высказывания со значением отказа: семантико-прагматический и когнитивный аспекты: Автореф. дисс. ... канд. филол. наук. - Барнаул, 2004. - 22 с.

5. Бычихина О. В. Модальные глаголы в высказываниях с семантикой отказа // Проблемы интерпретационной лингвистики: автор-текст-адресат. Межвузовский сборник научных трудов. - Новосибирск: Изд-во НГПУ, 2000. - С. 155-164.

6. Бычихина О. В. Семантические различия и особенности функционирования лексеммаркеров высказываний с семантикой отказа // International Higher Education Research. Vol. IX / Edited by Masanao Takeda. - Hokkaido University Sapporo, Japan, September 2008. C. $137-145$.

7. Грузберг Л. Язык как система сложного динамизма // Филолог. - Вып. № 14 [Электронный peсурс]. - Режим доступа: - http://philolog.pspu.ru/module/magazine/do/mpub_14_277 (дата обращения: 11.10.2013).

8. Дементьев В. В. Теория речевых жанров. - М.: Знак. - 2010. - 600 с. (Коммуникативные стратегии культуры).

9. Латфулина 3. Р. Модусные показатели диалектного высказывания: авторизация и персуазивность // Вестник Томского государственного университета. - 2014.- № 380. - С. 29-33.

10. Минг-Джер Ченг. Китайский бизнес изнутри: практическое пособие по выстраиванию деловых отношений с китайскими партнерами. - М.: Эксмо, 2009. - 288 с.

11. Новик И. Б. Сложные динамические системы // Наука и техника. - 2010, 4 июля. DOI: http://naitex.ru/content/view/110/30/

12. Ружа О. А. Есть ли дом у бездомного? (Представление о бездомном в русской языковой картине мира) // Вестник Новосибирского государственного педагогического университета. - 2014. - № 3. - C. 75-83. DOI: http://dx.doi.org/10.15293/2226-3365.1403.08

13. Современный русский язык / Под ред. В. А. Белошапковой. - М.: Высшая школа, 1989. $800 \mathrm{c}$.

14. Трипольская Т. А., Гончарова Е. А. Динамические процессы в лексиконе языковой личности // Вестник Новосибирского государственного педагогического университета. - 2014. - № 3. - C. 57-67. DOI: http://dx.doi.org/10.15293/2226-3365.1403.06

15. Шпильман М. В. Динамический аспект оценочной интерпретации действительности языковой личностью (на материале прозы А. и Б. Стругацких) // Проблемы интерпретационной лингвистики. Межвузовский сборник научных трудов. - Новосибирск, 2004. - С. $62-$ 75. 
Bychikhina Olga Vladimirovna, Candidate of Philological Sciences, Associate Professor of Department of Russian and Eastern Languages, Siberian Transport University, Novosibirsk, Russian Federation.

E-mail: bychikhina.olga@yandex.ru

\title{
ANALYSIS OF THE MAIN COMMUNICATIVE MODELS OF RUSSIAN AND CHINESE BUSINESS DISCOURSES
}

\begin{abstract}
In this article the author does attempt to analyse language and extralinguistic features of business by Chinese and Russian partners. The purpose of article - to allocate and characterize the main communicative models of the Russian and Chinese business discourses. It is said that one of manifestations of the active dynamic processes which have happened in language lately, change of strategy of conducting communication, including business communications is. Relevance of a subject is caused by that economic progress of China became most obvious recently, businessmen of their many countries of the world, including from Russia, seek to improve confidential business relations with Chinese, therefore, the knowledge of semantic features of creation of the Chinese and Russian business communication allows to avoid many mistakes, prevents intensity and misunderstanding in the relations between business partners. Special attention is paid to the comparative analysis of the use of traditional

Chinese and Russian communication models. The Chinese and Russian approaches to conducting business negotiations are compared by various criteria, such as: intonation, purpose of communication, communication dominant, main source of information, strategy of business, feature of communication and language means. The fixed language assets of expression of straight lines and indirect speech genres with semantics of refusal are separately allocated.

\section{Keywords}

theory of speech genres, direct / indirect speech genre, ways of expressing refusal Modus indicators, persuasiveness, active processes in the Russian language, business negotiations, business culture, communications model
\end{abstract}

\section{REFERENCES}

1. Barancheeva E. I. Verbalization features of memory processes: lexicographical limits and discourse representation. Novosibirsk State Pedagogical University Bulletin. 2014, no. 4, pp. 118-132. DOI: http://dx.doi.org/10.15293/2226-3365.1404.11

2. Basalaeva E. G. On some peculiarities of formation odorativnoy metaphorical microsystems Russian language. Siberian Journal of Philology. 2011, no. 4, pp. 192-199. (In Russian)

3. Basalaeva E. G., Bokareva Y. M. Linguistic manipulation of the discourse of representatives of network marketing. Discourse lies and lies as a discourse: Interuniversity collection of scientific papers. (ed.) T. A. Tripolskaia. Novosibirsk, Novosibirsk State Pedagogical University Publ., 2012, pp. 154-164. (In Russian)

4. Bychikhina O. V. Statements with value of refusal: semantiko-pragmatical and cognitive aspects: Abstract cand. philol. sciences. Barnaul, 2004, 22 p. (In Russian) 
5. Bychikhina O. V. Modal verbs in statements with semantics of refusal. Problems of interpretative linguistics: author-text-addressee. Interuniversity collection of scientific works. Novosibirsk, Novosibirsk State Pedagogical University Publ., 2000, pp. 155-164. (In Russian)

6. Bychikhina O. V. Semantic distinctions and features of functioning of lexemes markers of statements with semantics of refusal. International Higher Education Research. Vol. IX. Ed. by Masanao Takeda. Hokkaido University Sapporo, Japan, September 2008, pp. 137-145. (In Russian)

7. Gruzberg L. Language as a system of complex dynamism. Philologist. No. 14 Available at: http://philolog.pspu.ru/module/magazine/do/mpub_14_277 (accessed: 11.10.2013). (In Russian)

8. Dement'ev V. V. Theory of speech genres. Communicative Strategies of Culture. Moscow, Zodiac Publ., 2010, 600 p. (In Russian)

9. Latfulina Z. R. Modus indicators dialect sayings: authorization and persuasiveness. Bulletin of Tomsk State University. 2014, no. 380, pp. 29-33. (In Russian)

10. Ming-Dzher Cheng. Chinese business from within: practical grant on forming of business relations with the Chinese partners. Moscow, Eksmo Publ., 2009, 288 p. (In Russian)

11. Modern Russian. Ed. V. A. Beloshapkova. Moscow, The higher school Publ., 1989, 800 p. (In Russian)

12. Novik I. B. Complex dynamic systems. Science and Technology. 2010, July 4. DOI: http://naitex.ru/content/view/110/30/ (In Russian)

13. Rouge O. A. Do house the homeless? (Submission of a homeless in Russian language picture of the world). Novosibirsk State Pedagogical University Bulletin. 2014, no. 3, pp. 75-83. DOI: http://dx.doi.org/10.15293/2226-3365.1403.08 (In Russian)

14. Tripolskaya T. A., Goncharova E. A. Dynamic processes in the lexicon of a language personality. Novosibirsk State Pedagogical University Bulletin. 2014, no. 3, pp. 57-67. DOI: http://dx.doi.org/10.15293/2226-3365.1403.06 (In Russian)

15. Spielman M. V. The dynamic aspect of the evaluation of interpreting reality language personality (based on the prose of A. and B. Strugatsky). Interpretive problems of linguistics. Interuniversity collection of scientific papers. Novosibirsk, 2004, pp. 62-75. (In Russian) 


\title{
УДК 811.161.1'373
}

\section{ЛЕКСИКОГРАФИЧЕСКОЕ ПОРТРЕТИРОВАНИЕ СЛУЖЕБНЫХ СЛОВ (НА ПРИМЕРЕ ЧАСТИЦЫ-СОЮЗА ТОЛЬКО)}

\author{
T. Н. Пермякова (Новосибирск, Россия)
}

\begin{abstract}
В статье анализируются лексикографические интерпретации частищы-союза только в словарях разных типов, обосновывается необходимость предъявления такой информачии о данной языковой единице, которая бы отражала современное ее употребление в устной и письменной речи. Цель статьи - на примере частищы-союза только попытаться представить лексикографический «портрет» служебного слова. Отмечается, что в распоряжении читателя лексикографических изданий находится разнообразная информаџия о слове, однако эта информачия либо рассеяна по различным словарям, либо не в полной мере отражсает современное состояние языка, что создает определенные трудности и неудобства для читателя. $B$ статье также поднимаются важные вопросы описания лексического значения частицы-союза, представления семантической структуры многозначной служебной единищы, что связано и с проблемой разграничения полисемии и омонимии. Подчеркивается, что лексикографическое описание каждого служебного слова должно быть полипараметральным и включать ряд зон, которые должны быть отражены в словарной статье, описывающей частииу-союз в рамках интегративного подхода. В заключение делаются выводы о тех зонах и параметрах, которые необходимы 8 словарной статье, описывающей служебное слово в соответствии с интегральным подходом и современным состоянием русистики.
\end{abstract}

Ключевые слова: лексикография, лексикографическое портретирование, служебное слово, частица-союз, словарная статья.

Понятие «лексикографического портрета» появилось благодаря необходимости систематизировать словарное описание языковой единицы, сделать его максимально адекватным языковой системе [1, с. 55].

В распоряжении читателя лексикографических изданий находится богатейшая разнообразная информация о слове. Но сложность заключается в том, что эта информация либо рассеяна по различным словарям, либо не в полной мере отражает состояние языка на определенном этапе его развития.

Одной из актуальных проблем современной лексикографии является интерпретация служебного слова. Проблема лексического значения служебных слов активно обсуждалась в последней трети XX в. Долгое время подвергался сомнению сам факт существования

Пермякова Татьяна Николаевна - кандидат филологических наук, доцент кафедры филологии, Новосибирский государственный технический университет.

E-mail: uchi70@mail.ru 
лексического значения у служебных слов как русскими, так и зарубежными лингвистами (П. А. Лекант, А. Н. Тихонов, Н. М. Шанский, Б. Рассел, Г. Глиссон и др.). Мы будем придерживаться точки зрения тех ученых (М. И. Черемисина, Т. А. Колосова,Р. П. Рогожникова, М. В. Ляпон), которые считают, что союзы не только выполняют функцию связи предикативных единиц, но и выражают смысловые отношения между ними. По нашему мнению, частицы, выполняющие союзные функции, также способны передавать семантику отношений между предикативными единицами.

Слово только не раз становилось объектом пристального изучения и описания в отечественной лингвистической литературе и лексикографии. Однако информация, представленная в толковых словарях, свидетельствует о непоследовательности в лексикографической интерпретации незнаменательных единиц.

Так, например, в словаре под редакцией Д. Н. Ушакова [12] слово только подается в следующих функциях и значениях: 1) наречие ограничительное; 2) наречие в значении «исключительно, единственно»; 3) наречие в значении «еще, пока ещзе»; 4) союз условный; 5) союз временной; 6) союз противительный; 7) частица. Данная словарная статья слова только демонстрирует отсутствие инвариантного значения, частеречный принцип разграничения значений; отсутствие имплицитного указания на возможность семантических связей между отдельными значениями.

С. И. Ожегов [6] на первое место у слова только выдвигает функцию частицы, кроме того, выделяется функция союза (временной или условно-временной и противительный); функция наречия указана только для разговорной речи.

Обращает на себя внимание тот факт, что значения лексемы только в функции ча- стицы у С. И. Ожегова дублируют наречные значения (заметим, весьма спорные) у Д. Н. Ушакова. Подобных расхождений грамматической квалификации того или иного слова (или значения слова) между словарями немало. Безусловно, эти расхождения, а также уязвимость словарной интерпретации предопределяются существенными особенностями класса частиц, не имеющего четких грамматических границ и включающего единицы, значения которых имеют свои особенности.

В Малом академическом словаре русского языка (MAC) на первое место выносится значение ограничительной частицы («не более, как; всего лишь»), а также выделительно-ограничительной («единственно, исключительно») или усилительной. Среди союзных значений выделяются следующие: противительный союз (соответствует по значению союзам: но, однако); в сочетании с другими противительными союзами: $\boldsymbol{a}, \boldsymbol{\mu o , ~} \boldsymbol{\alpha} \boldsymbol{a}(\boldsymbol{a}$ только, но только, да только); в составе уступительного союза разве только (что); в сочетании с союзом и (и только); в составе противительного союза не только..., но (u); временной союз, употребляющийся для присоединения придаточных временных предложений (и только..., как) что свидетельствует о непоследовательности в разграничении слова только и его союзных сочетаний; в составе сложных союзов: едва только, как только, лишь только, чуть только, только чmo.

Одно из значений слова только МАС связывает с функцией наречия (едва, едва лишь), передающего его информацию, связанную с совершением какого-либо действия, с настроением какого-либо состояния.

Следует отметить, что наиболее полная характеристика лексемы только представлена в Большом академическом словаре (БАС). 
Вестник Новосибирского государственного педагогического университета

5(21)2014 www.vestnik.nspu.ru ISSN 2226-3365

Как и в MACе, на первом месте дано описание частичной функции слова только, вносящего в предложение элементы выделительно-ограничительной, ограничительновыделительной, ограничительной, усилительной семантики или выступающего в роли модальной частицы. Другие значения связаны с функцией наречия. Среди союзных значений лексемы только ведущим является временное (едва, едва лишь), затем разъясняется его функция противительного союза, указаны случаи употребления только в составе сложных соединительных и условных союзов (не только..., но и; не только.., но далее; не только..., но ещце; как только; если только; если бы только).

В словарной статье «Словаря служебных слов русского языка» [9], посвященной слову только, ведущей определяется функция частицы; 5 модификаций основного значения лексемы только даны с учетом семантических, синтагматических, синтаксических и стилистических особенностей данного слова; отмечены случаи фразеологизированных сочетаний с названной частицей (только и всего; и только; только бы; да и только; только что не).

В нашей статье мы рассматриваем слово только как единицу полифункциональную. Нам близка позиция Е. А. Стародумовой, которая отмечает, что «полифункциональность можно определить как употребление одной и той же единицы в разных синтаксических функциях - при сохранении единого семантического инварианта - и отнести к широкому понятию «синтаксической деривации» [11, с. 12]. Под деривацией понимаем термин, связанный и с фактом образования нового слова с целью передачи синтаксической функции, и с фактом выполнения одним словом различных (вторичных) синтаксических функций [5].
Однако анализ лексикографических источников показал, что метаязык описания служебных единиц в словарях несовершенен, что эксплицируется в грамматических пометах, содержащихся в словарной статье. Все анализируемые словари содержат общепринятую грамматическую (метаязыковую) помету - «союз» (или «сз.»). Однако составители словарей, как справедливо отмечает С. Г. Ильенко, «проявляют при этом не всегда оправданный консерватизм и некритическое слепое подражание существующим издавна лексикографическим образцам, совсем (или почти совсем) не заботясь о введении тех новых подходов к классификации частей речи, которые существуют в специальной грамматической литературе» [4, с. 586]. И действительно, уже более двадцати лет существуют термины, предложенные Т. А. Колосовой и М. И. Черемисиной (союзный функтив, союзная скрепа) или М. В. Ляпон (аналог союза), и ни один из них, к сожалению, пока по каким-то причинам не «прижился» в лексикографической литературе.

Кроме этого, в анализируемых словарях при описании служебной лексики часто не дифференцируется омонимия и полисемия. Например, в словарных статьях лексема только, как уже отмечалось, сопровождается грамматической пометой «наречие, частица и союз». А далее в одной словарной статье характеристики этой лексемы как наречия, частицы и союза представлены в виде лексикосемантических вариантов; причем не ясно, каким критерием обусловлен порядок следования этих лексико-семантических вариантов. Каждый ЛСВ, представляющий только как союз, содержит информацию о его синтаксической и отчасти семантической функции. Причем значение противительного союза и условно-временного представлены как лексико-семантические варианты. Общеиз- 
вестно, что семантическая природа этих значений не одинакова, следовательно, представление в словарной статье данной информации в качестве семантических вариантов одного слова оказывается, на наш взгляд, не мотивированным.

Создавшаяся ситуация свидетельствует о непоследовательности в лексикографической интерпретации незнаменательных единиц, что связано со слабой теоретической разработанностью вопроса о семантической интерпретации частиц и союзов в словарях, о дифференциации омонимии и полисемии незнаменательных слов.

Поскольку наше внимание сосредоточено на только в союзной функции, мы считаем возможным использовать термин частица-союз, предложенный В. В. Виноградовым [3]. Ведь если рассматривать множество показателей союзной связи как полевую структуру, ядро которой представляют однословные скрепы, или собственно союзы (например: $\boldsymbol{a}, \boldsymbol{u}, \boldsymbol{н о}, \boldsymbol{ч m o ~ и ~ т . п . ) , ~ о к о л о я д е р - ~}$ ную зону - единицы, которые в школьной и традиционной грамматике называют составными союзами; и, наконец, зону отдаленной периферии, которая является областью пересечения с другими полями, занимают языковые единицы, способные в ряде случаев выполнять союзную функцию: местоимения, частицы, вводно-модальные слова и т.п. Именно в этой зоне и находится лексема только.

Повторим, что одной из самых важных является проблема описания лексического значения частицы-союза, а также представления семантической структуры многозначной единицы, что связано и с вопросом разграничения многозначного слова и омонима. Все эти проблемы неизбежно важны и чрезвычайно затруднительны для составителей любого словаря.
Как уже было сказано, нуждается в обновлении также иллюстративный материал, который не отражает современной языковой ситуации. Роль иллюстративного материала как важного элемента словарной статьи, как показано в теоретических работах по лексикографии, во вступительных статьях к толковым словарям, заключается в следующем: 1) оправдать включение слова в словарь; 2) показать принадлежность словарной единицы к лексической системе современного русского языка; 3) убедить в наличии определенного лексического и грамматического значения; 4) стремиться к точной семантической интерпретации лексического значения словарной единицы; 5) показать область употребления; 6) показать наиболее типичное контекстное окружение словарной единицы. Анализ иллюстративного материала, как совершенно справедливо отмечают Е. Ю. Булыгина и Т. А. Трипольская [2], играет важную роль в отражении и формировании языковой картины мира адресата. Кроме того, цитатный материал при отражении в словаре прагматического содержания оказывается в ряде случаев более значимым, чем толкование и пометы, причем цитатный материал, или иллюстрации, на наш взгляд, не всегда целесообразно сосредоточивать в одной зоне, он может быть «рассыпан» по словарной статье в зависимости от типа лексики, описываемой в словаре.

Опираясь на опыт составителей «Словаря служебных слов русского языка», а также на работы Н. П. Перфильевой [7], посвященные проблемам параметризации лексических служебных единиц, мы полагаем, что лексикографическое описание каждого служебного слова должно быть полипараметральным и включать ряд зон.

Проведем «инвентаризацию» тех лексикографических параметров, которые должны 
быть отражены в словарной статье, описывающей частицу-союз в рамках интегративного подхода и исходя из современного «состояния» теоретической лингвистики.

\section{1. Заголовочная единица, или вокабу-} ла, включает два обязательных лексикографических параметра: орфографический, содержащий графическую информацию о словарной единице, и орфоэпический с информацией о произносительных и акцентологических нормах, которая может быть представлена транскрипцией описываемой единицы.

2. Семантическая зона включает обязательные лексикографические параметры толкование, синонимический ряд, имплицитную информацию о лексеме как однозначной / многозначной единице. Описание многозначной частицы-союза должно удовлетворять следующим требованиям: 1) мотивированный порядок следования ЛСВ в словарной статье; 2) представленность интегрального компонента / макрокомпонента, объединяющего ЛСВ, и дифференциальных сем.

Поскольку прагматическая информация в содержательной структуре частицы-союза или союзной скрепы тесно переплетена с семантической, то отдельно прагматический параметр в словарной статье не выделяется, а эта информация должна быть максимально эксплицирована при описании семантики данной единицы.

В частности, в семантической зоне словарной статьи представлен функциональностилистический параметр эксплицитно, если частица-союз является стилистически маркированной. Если слово стилистически нейтрально, то обычно помета о функционально-стилистической принадлежности в словаре отсутствует, что также является информацией для читателя. В обоих случаях на основе этой информации пользователь делает выводы о сфере употребления частицы-союза и о возможности использовать эту единицу в плане антропоцентрической характеристики говорящего (например, образованная/необразованная языковая личность).

Семантическая зона сопровождается иллюстративным материалом - контекстами различной стилистической принадлежности. Эта часть семантической зоны, как уже было сказано, может выполнять функцию презентации новой информации о слове, которая не отражается ни в толковании значения, ни в пометах.

3. Грамматическая зона содержит обязательные параметры: а) информацию о частеречной принадлежности словарной единицы или о соотнесенности с определенной частью речи; б) грамматическое значение - частица выполняет функцию сочинительного или подчинительного союза. Данный параметр может содержать информацию о радиусе действия описываемой единицы в зависимости от того, универсальной или специализированной она является.

4. Дистрибутивный анализ частицысоюза помогает определить ее формальные функции, поэтому вполне логичен переход к следующему обязательному параметру «Формальные функции». Частица-союз может выполнять конструктивную и иногда текстообразующую функции. Напомним, под конструктивной функцией мы понимаем способность скрепы соединять части простого или сложного предложения, образуя некую конструкцию; под текстообразующей - соединять части текста, обеспечивая тем самым его связность и целостность. На базе данного параметра определяется статус лексемы как универсальной или специализированной.

Данная зона может включать и факультативный параметр - информация о грамматических условиях реализации данной единицы или одного из ее ЛСВ - о сочетаемости 
модальных и временных планов предикативных единиц, которые она связывает. Данная информация имплицитна, если нет особых ограничений в плане такой сочетаемости, и эксплицируется, если есть какие-либо ограничения. Рассматриваемая зона сопровождается иллюстративным материалом.

Таким образом, в словарной статье отражаются следующие зоны и параметры, не- обходимые в соответствии с интегральным подходом и современным состоянием русистики: толкование, синонимический ряд, информация о лексеме как моно- или полисеманте, функционально-стилистический параметр, которые в совокупности составляют зону «Семантика»; грамматическое значение, радиус действия, формальные функции лексемы, входящие в зону «Грамматика», а также факультативная зона «Дериваты».

\section{СПИСОК ЛИТЕРАТУРЫ}

1. Апресян Ю. Д. Основные принципы и понятия системной лексикографии // Языковая картина мира и системная лекскография. - М.: Языки славянской культуры, 2006. - С. 33-74.

2. Булыгина Е. Ю., Трипольская Т. А. Отражение картины мира в словаре: иллюстративный материал в структуре словарной статьи // II Межд. конф. «Русский язык и литература в международном образовательном пространстве: современное состояние и перспективы» к 55-летию преподавания русского языка в Испании. - Гранада, 2010. - Т. II. - С. 2131-2136.

3. Виноградов В. В. Русский язык (Грамматическое учение о слове) / под ред. Г. А. Золотовой. - М.: Русский язык, $2001-$ С. 577-592.

4. Ильенко С. Г. Русистика: избр. труды. - СПб.: РГПУ, 2003. - 586 с.

5. Курилович Е. Очерки по лингвистике: сборник статей. - М.: Издательство литературы на иностранном языке, 1962. -490 с.

6. Ожегов С. И., Шведова Н. Ю. Толковый словарь русского языка. - М.: АЗ, 1995. - 928 с.

7. Перфильева Н. П. Метатекст: текстоцентрический и лексикографический аспекты: автореф. дис. ... докт. филол. наук. - Новосибирск, 2006. - 25 с.

8. Словарь служебных слов русского языка / А. Ф. Прияткина, Е. А. Стародумова, Г. Н. Сергеева и др. - Владивосток: ДвФУ, 2001. - 363 с.

9. Стародумова Е. А. Частицы русского языка (разноаспектное описание). - Владивосток: ДвФУ, 2002. - 292 с.

10. Щур М. Г. Частицы в толковых словарях // Словарные категории. - М.: Наука, 1988. C. 83-87. 
DOI: $10.15293 / 2226-3365.1405 .18$

Permyakova Tatyana Nikolaevna, Candidate of Philology Sciences, Associate Professor of the Department of Philology, Novosibirsk State Technical University, Novosibirsk, Russian Federation. E-mail: uchi70@mail.ru

\title{
LEXICOGRAPHICAL PORTRAYING FUNCTIONAL WORDS (BY THE EXAMPLE OF THE PARTICLE-CONJUNCTION TOL'KO)
}

\begin{abstract}
The article analyzes lexicographical interpretation of the conjunction brace только in dictionaries of different types, and describes the rationale to submit such information on this linguistic unit that would reflect modern usage of the particle-conjunction только in oral and written speech.

The purpose of the article is by the example of the particle-conjunction только to attempt to represent a lexicographical "portrait" of the functional word. It is noted that the information about the functional word, which the reader of lexicographic editions has at the disposal, is either distributed among various dictionaries, or do not fully reflect the current state of the language, therefore, it causes some difficulties and inconveniences for the reader. The article also raises important questions of the description of the lexical meaning of the particle-conjunction, representation of the semantic structure of the polysemantic functional unit, which is referred to the problem of polysemy and homonymy differentiation. It emphasizes that lexicographic description of each functional word should consider several parameters and include a number of areas reflected in the dictionary entry describing the particle-conjunction within the integrative approach. The article describes those areas and parameters of a dictionary entry which determines a functional word in accordance with the integrative approach and the current state of Russian Studies.
\end{abstract}

Keywords

lexicography, lexicographical portraying, functional word, particle - conjunction, dictionary entry

\section{REFERENCES}

1. Apresyan Yu. D. Basic principles and concepts of systematic lexicography. Language picture of the world and system lexicography. Moscow. Language Slavic Cultures Publ., 2006. pp. 33-74. (In Russian)

2. Bulygina E. Yu., Tripolskaya T. A. Reflection of the picture of the world in the dictionary: illustrative material in the structure of the entry. II Int. conf. "Russian language and literature in the international educational space: Current Status and Prospects" to the $55^{\text {th }}$ anniversary of Russian language teaching in Spain. Granada, 2010, Vol. II, pp. 2131-2136. (In Russian)

3. Vinogradov V. V. Russian language (grammatical teaching of the word). (Ed.) G. A. Zolotova. Moscow, Russian language Publ, 2001. pp. 577-592. (In Russian)

4. Ilienko S. G. Russian studies: selected works. St. Petersburg, Herzen State Pedagogical University of Russia Publ., 2003. 586 p. (In Russian)

5. Kurilovich J. Essays on linguistics: a collection of articles. Moscow, Publishing House of Foreign Lit., 1962. 490 p. (In Russian)

6. Ozhegov S. I., Shvedova N. Y. Dictionary of the Russian language. Moscow, 1995. 928 c. (In Russian) 
7. Perfilieva N. P. Meta text: textocentric and lexicographical aspects. Abstract. diss. ... Doctor of Philological Sciences. Novosibirsk, 2006. 25 p. (In Russian)

8. Dictionary of function Russian words. A. F. Priyatkina, E. A. Starodumova, G. N. Sergeeva, etc. - Vladivostok, Publishing House of the Far Eastern university Publ., 2001. 363 p. (In Russian)

9. Starodumova E. A. Particles of the Russian language (multiaspect description). Vladivostok, Publishing House of the Far Eastern university Publ., 2002. 292 p. (In Russian)

10. Shchur M. G. Particles in the dictionaries. Glossary category. Moscow: Nauka Publ., 1988. pp. 83-87. (In Russian) 


\title{
УДК 811.161.1'38 + 821.161.1(092) + Гумилёв Л. Н.
}

\section{СТИЛИСТИЧЕСКОЕ ВАРЬИРОВАНИЕ ДИСКУРСА Л. Н. ГУМИЛЕВА ПРИ ИСПОЛЬЗОВАНИИ ИМ КОМПАРАТИВНЫХ ТРОПОВ}

\author{
Е. Б. Бачурина (Новосибирск, Россия)
}

\begin{abstract}
В статье сопоставлены особенности использования компаративных тропов (как единич ФСП компаративности) в академических и научно-популярных работах известного ученого Л. Н. Гумилёва и тем самым определены отдельные черты языковой личности автора. Отмечается, что Л. Н. Гумилёв, выбирая нетрадииионный стиль изложения в более поздних рабоmax, сознательно предпочел принятому академическому канону живой язык повествования. Подчеркивается, что в ранних работах преобладают синтаксические компаративы: сравнения-сопоставления, сопоставительные структуры, а в более поздних количество лексикосемантических компаративов, то есть метафор, заметно возрастает.

В заключении делается вывод о том, что в трудах Л. Н. Гумилёва проявилась одна из заметных черт его языковой личности - стремление к экспрессивизации академического изложения, проявляющаяся в использовании книжных и разговорных фразеологических единии, основаниями которых являются сравнения, метафоры и литературные реминисценции.

Ключевые слова: компаративные тропы (сравнение-сопоставление, образное сравнение; метафора: стертая, образная, индивидуально-авторская), академический и учебноописательный подстили научного изложения.
\end{abstract}

Цель данной статьи - сравнить особенности использования компаративных тропов в разновременных текстах Л. Н. Гумилёва и тем самым выявить стилистические сдвиги в дискурсе автора.

Л. Н. Гумилёв начал активно публиковаться в 1959 г. В своей работе «Древняя Русь и Великая степь» (2006) он заметил следующее: «Самые мелкие детали, необходимые для уточнения хода событий, описаны в статьях традиционными приемами исторического исследования... (выделено нами. - Е.Б.) Та- ких статей - исторических, географических и археологических - пришлось написать более ста» (Гумилёв, 2006, с. 12). Обобщение собранного материала дало жизнь специальным монографиям («Хунну», 1960; «Хунну в Китае», 1974; «Древние тюрки», 1967), которые были выполнены не только «традиционными приемами», а, как писал сам автор, используя слова Г. Р. Державина, «забавным русским слогом» (Гумилёв, 2006, с. 12). Выбирая нетрадиционный стиль изложения, Л. Н. Гумилёв сознательно предпочел принятому акаде-

Бачурина Елена Борисовна - аспирант кафедры современного русского языка, Новосибирский государственный педагогический университет.

E-mail: bachur08@mail.ru 
Вестник Новосибирского государственного педагогического университета

5(21)2014 www.vestnik.nspu.ru

ISSN 2226-3365

мическому канону живой язык повествования, который не снижает научной достоверности, но повышает степень доходчивости и легкости восприятия. Примечательно, что автор просит принимать «забавный русский слог» в научном исследовании как эксперимент, стилистический и композиционный, тем самым эксплицируя себя не только как историка и этнолога, но и, частично, как стилиста.

В текстах Л. Н. Гумилёва мы анализируем компаративные тропы, а именно: генетически связанные сравнения и метафоры. Метафоры, как известно, соотносятся с лексико-семантическим уровнем, а сравнения прежде всего с синтаксическим. «Сравнение - это один из главных способов осмысления действительности, - пишет Н. Д. Арутюнова, - что сделало его предметом логики. Одновременно сравнение - одна из форм художественного мышления, что сделало его предметом поэтики и стилистики» [1, с. 353].

По наличию/отсутствию компонента образности (яркого эмоционального представления) сравнения делятся на образные (сравнения-уподобления) и сравнениясопоставления - стандартные, безобразные (В. М. Огольцов, Е. В. Скворецкая, М. И. Черемисина и др.). Сущность сравнения состоит в сопоставлении двух или нескольких предметов, явлений, действий, качеств, имеющих близкие или одинаковые признаки (и тогда мы имеем дело с безобразным сравнением) или неблизкие, разнородные по семантике (в этом случае речь уже идет об образных сравнениях).

Вслед за Н. Д. Арутюновой, метафору мы понимаем как «троп или фигуру речи, употребление слова, обозначающего некоторый класс объектов, явлений, действий или признаков для характеризации или номинации другого, сходного с данным классом объ- екта или индивида» [1, с. 233]. Подчеркнем, что метафора соотносится только со сравнением-уподоблением.

В ранних работах исследователя, ориентированных на академическое изложение, часто используются не образные сравнения, а сравнения-сопоставления, например: Озера мелеют, рыба в них гибнет, и в тундру, как и в степь, приходит голод.

Сравнения-сопоставления часто маркируются составными союзами, актуализирующими уточнение: подобно тому как, как и, так же как, например: Но в монгольской религии, как и в шаманизме, нет понятий рая и ада, а есть понятия «верхнего» и «нижнего» миров, идентичных нашему «среднему» миру; Усыхание степи сверх привычного им предела подорвало их скотоводческое хозяйство, подобно тому, как раньше оно разрушило хозяйство хазар.

Маркерами сравнения-сопоставления могут также быть специализированные предлоги: подобно, наподобие (Подобно китайским историкам...), сопоставительная интонация, например: Летучие отряды хуннов производили грабежси в разных областях $\mathrm{Ce}$ верного Китая, китайщьы ограничивались обороной.

Сопоставления не по сходству, а по различию могут выражаться при помощи частицы не вместе с союзами но или $a$, например: Но не андроновцы играли первую роль в Южной Сибири во втором тысячелетии до нашей эры.

Указанные средства сопоставления в пределах одного предложения смогут соединяться с образными сравнениями, выраженными, например, словообразовательно, что несколько нарушает академический слог, сообщая высказыванию экспрессивность, например: Игорь Ольгович был зверски убит 
Вестник Новосибирского государственного педагогического университета

5(21)2014 www.vestnik.nspu.ru ISSN 2226-3365

не своим победителем Изяславом Вольнским, а толпой киевлян.

В ранних работах значительно больше форм сравнений-различий, выраженных сравнительной степенью прилагательных и наречий. В основном такие формы выражают не образное, а логическое сравнение, но сопутствующие оценочные значения, поддержанные обильными перечислениями и наречиями меры и степени (гораздо), экспрессивизируют изложение событий: Но есть вещуи хужсе войны: обращуение в рабство, оскорбление чтимых святынь, разграбление имущзества и, наконец, оскорбительное пренебрежение; Гораздо страшнее сложилась коллизия в «мусульманском мире».

В поздних работах использование форм сравнительной степени соответствует образному сравнению, например: Страшнее сабель и стрел дейлемитов оказалась вспьхнувиая в лагере руссов дизентерия. Соотношение неоднородных предметов: дизентерия и сабли, стрель - делает сравнение образным. Сабли и стрель используются в дискурсе Л. Н. Гумилёва и в прямом, и в переносном употреблении. Такое явление Н. А. Кожевникова рассматривает как мотивацию тропов предметным миром произведения (то есть «реалиями») [8]. В таких случаях текст становится более суггестивным, и подобные примеры свидетельствуют о том, что дискурс Л. Н. Гумилёва соединяет научнопопулярный стиль с художественным.

Следует заметить, что в работах Л. Н. Гумилёва начального периода, выдержанных в духе «традиционных приемов», встречаются и образные союзные сравнения (степь как море), и образные метафоры: «таежное море» (кавычки авторские - Е.Б.), летучие отряды Однако их в ранних работах их в 2,4 раза меньше, чем в поздних.
В ранних работах Л.Н.Гумилёва встречается немало устойчивых выражений разного типа, в формировании которых участвуют или метафора, или сравнение, а именно:

- наличие книжных, в том числе и художественных реминисценций: Некоторый свет на этот запутанный вопрос проливают античные историки, в частности Птоломей; В монголах укоренилось представление о родовом коллективе как основе социальной жизни, о родовой (коллективной) ответственности за судьбу любого рода и об обязательной взаимовыручке. А ещзе позднее - легенду стали воспринимать как сказку, потому что фольклористика и биофизика ещуе более несовместимы, чем гений и злодейство (Пушкинское гений и злодейство в качестве образа сравнения по различию, несомненно, увеличивает степень эмоционального воздействия текста);

- наличие разговорных фразеологизмов, несмотря на академический характер более ранних работ: Однако привлечение широкого материала из истории окрестных стран позволило А.Ю. Якубовскому отнестись критически к банальному пониманию истории Руси и половецкой степи как к вечной войне не на жсизнь, а на смерть; Дыма без огня не бываem, и причиной слуха был разгром войск сельджукского хана.

Использование понятий, связанных с определенным историческим периодом, выраженных архаическими устойчивыми выражениями, в рамках сопоставительных конструкций, маркированных союзами $а$, чем, сохраняет академический характер изложения в ранних сочинениях автора, соответствующих определенной эпохе: ... смерть полагалась лишь за ослушание на войне, а при воровстве и убийстве разрешалось откупаться скотом. Кочевое пастушеское хозяйство хуннов в первом тысячелетии до 
Вестник Новосибирского государственного педагогического университета

5(21)2014 www.vestnik.nspu.ru ISSN 2226-3365

нашей эры было значительно более высокоорганизованно, чем хозяйство их оседльх соседей.

Принадлежность ранних работ Л. Н. Гумилёва академическому подстилю научного изложения в области истории и этнологии подтверждается использованием:

- названий народов: Чжсурчжэньские «Алтан-хань»» (титул, обозначавший «золото» и эквивалентный китайскому Кинь, совр. Цзинь. - Е.Б.) не любили татар, но использовали их против кераитов и монголов; Известно, что монголы предпочитали использовать контингенты покоренных народов вдали от родины, и естественно, что часть войска Батыл была укомплектована ижсрчэсэнями, тогда как в войсках его кузена Хубилая, владевшего Китаем, служили кыпчаки (половцы), аланы и русские);

- собственных имен: Давидовичи (дети Давыда Святославича) предали Ольговичей, но те удержались потому, что, видимо, черниговцы так жсе не хотели Мономашичей, как киевляне - Ольговичей;

- топонимов: В эпоху Цюй Юаня восточные юэ еще держались в Цзян-нани и доставляли китайцам больше неприятностей, чем освоенное для плавания море.

В поздних работах, например, в книгах «Древняя Русь и Великая степь», «От Руси до России» и др. в 2,3 раза реже встречаются перечисленные компоненты, в 2 раза меньше примеров использования абстрактной лексики.

Мы кратко осветили особенности использования компаративных тропов в ранних академических трудах Л. Н. Гумилёва. Далее обратим внимание на то, как применяются сравнения и метафоры в более поздних работах историка и этнолога. Сразу заметим, что если в ранних работах преобладают синтаксические компаративы: сравнения- сопоставления, сопоставительные структуры, - то в более поздних количество лексикосемантических компаративов, то есть метафор, заметно возрастает.

Историографический источник (текст), по мнению Н. А. Мишанкиной, создается с целью передачи информации о прошлом, его автор претендует на непредвзятое изложение событий, научную позицию по отношению к описываемому. Однако, несмотря на жесткий фактографический каркас, исторический научный текст, также как и другие виды гуманитарных текстов, представляет метафорическую систему, репрезентирующую модель объекта [10, с. 52-61].

В работах Л. Н. Гумилёва (особенно созданных в последние десятилетия) можно наблюдать насыщенность многих фраз элементами художественности, разговорности, что соотносится с образным сравнением и метафорой: Накопление богатства ради богатства каждому родовичу показалось бы бессмысленным и грязным занятием, но если бы кто-либо стал «обжимать» (кавычки автора. - Е.Б.) соплеменников, то те бы его либо выгнали, либо убили как выродка.

Образные сравнения нередко очень распространенные и актуализируют экспрессивно значимую семантику интенсивности в представлении бытовой картинки: Система деформируется, как автомобиль, несущийся с такой скоростью, что от него отлетают колеса, ломаются оси.

Иногда в одном предложении можно встретить и малоизвестный термин, компаративный образ в рамках разговорного стиля: Существует мнение, что этносфера создалась при появлении человека, причем именно этот момент именуется этногенезом, а потом этносы лишь меняются местами, как карты в пасьянсе. 
Вестник Новосибирского государственного педагогического университета

5(21)2014 www.vestnik.nspu.ru

ISSN 2226-3365

Если в работах, созданных с 1960 по 1970 гг., преобладают стертые метафоры ( $A p$ хеологическая культура (данного народа), представляющая собой кристаллический след его исторической судьбы...; Китайские пограничные войска были разбиты и отступили, обнажнив границу), то в трудах последних двух десятилетий чаще появляются и образные метафоры. Отметим из них:

- деструктивные: Но гораздо более сильной была травма 1223 г. - битва на Калке и 1224 2.- падение Юрьева, где ливонские рыцари пощуадили пленных эстов, но не оставили в живых ни одного русского; При Святославе надлом был преодолен, и русский этнос вступил в фазу постепенного угасания страстей, забвения идеалов и торжества себялюбия как социального императива поведения;

- когнитивные метафоры, например: Первая [офищиальная история] поливала образ Тэмуджина лестью, пока не превратила его в лакированную куклу, а вторая [«тайная»] собирала сплетни и сдабривала ими повествование. По Н. Д. Арутюновой, когнитивная метафора представляет собой сопоставление «субъекту метафоры признаков, свойств и действий, характерных для другого класса объектов или относящихся к другому аспекту данного класса...» [1].

Метафоры в более поздних работах активно участвуют в экспликации ключевого понятия исследователя - пассионарность. Понятие «пассионарность» и сопровождающие метафорические ряды являются своеобразным стержнем, который держит весь текст и является сквозным образом. Понятие «пассионарность» представлено следующим градационным метафорическим рядом: энергия / напряжение / рождение / пассионарный толчок / надлом / взрыв:
- Видимо, наиболее правильно объяснить ее [кривую проявления пассионарности] как инерционную, возникающую время от времени вследствие «толчков», которыми могут быть только мутации, вернее микромутации, отражающиеся на стереотипе поведения, но не влияющие на фенотип;

- Зато идеологическая система при набухающей пассионарности этноса всегда агрессивна, вследствие чего для соседей опасна;

- Но «белье кровяные шарики» (лейкоциты. - Е.Б.) - местные пассионарии ликвидировали инфекцию, следом которой осталось только название князей-воинов Рюриковичи.

Начало же этому метафорическому ряду было положено в одной из ранних работ: $И$, наконец, пассионарный толчок описан как облучение плода в утробе (Монголы и меркиты, 1977).

Сквозные для работ Л. Н. Гумилёва образы, связанные с различными науками: биологией, физиологией, медициной, строительством, театром присутствуют и в ранних, и более масштабно в поздних работах: Это зародыш государственной власти оказывается более древним, чем институт государства, основанный на насилии одного класса над другим; Эта [пропаганда любых неканонических идей] "раковая опухоль» разъела тело халифата; $K$ середине $X V$ века на месте древнерусского этноса возникли три новых, непохожих на своего одряхлевщего предка.

Одной из специфических черт языковой личности Л. Н. Гумилёва можно назвать использование на протяжении всего творчества ярких, образных выражений, созданных на основе разговорных, религиозных, литературных текстов, что свидетельствует и о его высокой степени компетенции, и о широте 
ассоциаций, и о яркости его эмоционального восприятия.

Сопоставив особенности использования компаративных тропов в сочинениях Л. Н. Гумилёва разных временных периодов, мы увидели следующее.

В ранних работах ученого-этнолога больше использовано сравнений, чем метафорических образов, и прежде всего сравнений-сопоставлений и смежных с ними сопоставительных структур, маркированных союзами $a$, чем, отрицательной частицей, сопоставительной интонацией. Уже в этих трудах Л. Н. Гумилёв проявилась одна из заметных черт его языковой личности - стремление экспрессивизировать академическое изложение, что проявляется в использовании книжных и разговорных фразеологических единиц, основаниями которых являются сравнения и метафоры, литературных реминисценций и так далее. Эта черта языковой личности ученого ярче проявилась в более поздних его монографиях, в которых уже гораздо чаще используются метафоры и образные сравнения (и нередко индивидуально-авторские). Цепочки компаративных образов участвуют в экспликации ключевой идеи работ Л. Н. Гумилёва - пассионарность.

\section{СПИСОК ЛИТЕРАТУРЫ}

1. Арутюнова Н. Д. Метафора и дискурс // Теория метафоры. - М.: Прогресс, 1990. - 512 с.

2. Гумилёв Л. Н. Великая распря в первом тюркском каганате в свете византийских источников // Византийский временник. - М.: Издательство Академии наук СССР, 1961. T. XX. - C. 75-89.

3. Гумилёв Л. Н. Древние тюрки. VI-VIII вв. Автореф. дис. ... докт. ист. наук. - Л.: ЛГУ, 1961. -28 c.

4. Гумилёв Л. Н. Памятники хазарской культуры в дельте Волги. - М.: Сообщение государственного Эрмитажа, 1965. - T. XXVI. - 512 с.

5. Гумилёв Л. Н. От Руси до России. - М.: Астрель, 2005. - 416 с.

6. Гумилёв Л. Н. Древняя Русь и Великая степь. - М.: Астрель, 2006. - 656 с.

7. Гусев С. С. Наука и метафора. - Л.: Ленинградский университет, 1984. - 192 с.

8. Кожевникова Н. А. О соотношении тропа и реалии в художественном тексте // Поэтика и стилистика. - М., 1991. - С. 37-63.

9. Кожина М. Н., Дускаева Л. Р., Салимовский В. А. Стилистика русского языка. - М.: Флинта, 2008. - 464 с.

10. Можаева Г. В., Мишанкина Н. А. Контент-анализ историографического источника (к вопросу о междисциплинарности лингвистических методов) // Вестник Томского ун-та. Томск: ТГУ, 2007. - № 294. - С. 52-61.

11. Огольцев В. М. Устойчивые сравнения в системе фразеологии. - Л.: ЛГУ, 1987. - 192 с.

12. Русский язык: энциклопедия / под ред. Ю. Н. Караулова. - М.: Большая Российская энциклопедия, 1997. - 721 с. 
Bachurina Elena Borisovna, Post-Graduate Student of the Department of the Modern Russian Language, Novosibirsk State Pedagogical University, Novosibirsk, Russian Federation.

E-mail: bachur08@mail.ru

\section{STYLISTIC VARIATION OF L. N. GUMILYOV'S DISCOURSE BY COMPARATIVE TROPES}

\footnotetext{
Abstract

In article gives the features of the usage of comparative tropes (ascomparative units of Functional Semantic Field) in the academic and popular scientific works of the famous scientist L. N. Gumilev and determines the individual features of language personality of the author. It is noted that L. N. Gumilev, choosing the unconventional style in later works, consciously chose adopted by the academic Canon living language of the narrative. It is emphasized that in early works prevail syntactic comparative: comparison - comparison, comparative patterns, and later the number of lexical and semantic comparatives, metaphors increased markedly.

To sum up, it is revealed one of the most noticeable features of L. N. Gumilev personality language - aspiration to an expressivization of the academic statement being shown in use of the book and colloquial phraseological units which bases are similes, metaphors, literary allusions.

Keywords

comparative tropes (simile, metaphor), academic and educational narrative styles of scientific statements

\section{REFERENCES}

1. Arutyunova N. D. Metaphor and discourse. Theory of metaphor. Moscow, Progress Publ., 1990, 512 p. (In Russian)

2. Gumilev L. N. Great feuds in the first Turkish Kaganate, in the light of the Byzantine sources. Byzantine annals. Moscow, Academy of Sciences of the USSR Publ., 1961. V. XX. pp. 75-89. (In Russian)

3. Gumilev L. N. The ancient Turks. VI-VIII centuries. Author's abstract, Leningrad: Leningrad State University Publ., 1961. 28 p. (In Russian)

4. Gumilev L. N. Monuments Khazar culture in the Volga Delta. Moscow, the Message of the state Hermitage. V. XXVI. 1965. pp. 49-51. (In Russian)

5. Gumilev L. N. From Rus to Russia. Moscow, 2005. 416 p. (In Russian)

6. Gumilev L. N. Ancient Rus and the Great steppe. Moscow, 2006. 656 p. (In Russian)

7. Gusev S. S Science and metaphor. Leningrad: Leningrad State University Publ., 1984. 192 p. (In Russian)

8. Kozhevnikova N. A. Selected Works on the Language of Fictional Literature. Poetics and Stylistics. Moscow, 1991. pp. 37-63. (In Russian)

9. Kozhina M. P., Duskaeva L. R., Salimovskiy W. A. Stylistics of Russian Language. Moscow, Flint Publ., 2008. 464 p. (In Russian)
} 
10. Mozhayeva G. V., Mishankin N. A. Content Analysis of Historiographic Source (on the interdisciplinarity of linguistic methods). Tomsk State University Review, no. 294, pp. 52-61. (In Russian)

11. Ogoltsev V. M. Sustainable Comparison in the System of Phraseology. Leningrad, Leningrad University Publ., 1987. 192 p. (In Russian)

12. Russian language: encyclopaedia. (Ed.) Y. U. Karaulova. Moscow, Big Russian Encyclopedia Publ.. 1997. 721 p. (In Russian) 


\title{
УДК 81.371
}

\section{СПОСОБЫ САМОПРЕЗЕНТАЦИИ В ПУБЛИЦИСТИЧЕСКИХ ТЕКСТАХ ДМИТРИЯ БЫКОВА (НА МАТЕРИАЛЕ «НОВОЙ ГАЗЕТЫ»)}

\author{
И. Г. Катенева (Новосибирск, Россия)
}

\begin{abstract}
Одной из тенденций развития современной журналистики является реанимация жанров художественно-публицистической группы, которые позволяют корреспондентам использовать разнообразные средства воздействия на иелевую аудиторию. В данной статье рассматриваются способы самопрезентачии, которые используются журналистами в текстах такого типа. Объектом исследования являются фельетоны Дмитрия Быкова, опубликованные в «Новой газете» за 2012 и 2013 годы. На странииах этого издания Дмитрий Быков выступает только в роли фельетониста. Его материаль позиционируются редакиией и воспринимаются иелевой аудиторией как своеобразный бренд газеты, что обусловливает выбор стратегии самопрезентации в качестве доминантой коммуникативной стратегии. $B$ статье описываются тактики, приемы и языковые средства, используемые данным автором для ее реализачии. В заключение сообщается, что сочетание в тексте различных способов самопрезентации позволяет журналисту не только повысить собственный статус и стать своеобразным брендом издания, но и оказывать эффрективное воздействие на сознание и восприятие окружающей действительности различными категориями читателей.
\end{abstract}

Ключевые слова: способы самопрезентации, коммуникативные тактики и приемы, фельетон, оппозиционное издание.

Одной из важных характеристик массмедийного дискурса конца XX - начала XXI вв. является усиление авторского начала и превалирование в текстах разных жанров авторской оценки над фактом [2-3, 5-6]. В связи с этим парадоксальной выглядит следующая тенденция: в данный период функционирования российской прессы невостребованным оказался жанр «фельетон», для которого указанные выше признаки являются жанрообразующими [4].
В середине 2000-х гг. отмечается реанимация группы художественнопублицистических жанров, в том числе и фельетона, который стал использоваться редакциями независимых и оппозиционных изданий. Корреспонденты газет и журналов такого типа рассматривали фельетон как эффективное средство выражения протестной информационной политики.

С этой точки зрения тексты Дмитрия Быкова, публикуемые на страницах «Новой

Катенева Ирина Геннадьевна - кандидат филологических наук, доцент кафедры журналистики, Новосибирский государственный педагогический университет.

E-mail: irina-kateneva@yandex.ru 
Вестник Новосибирского государственного педагогического университета

5(21)2014 www.vestnik.nspu.ru

ISSN 2226-3365

газеты», представляют особый интерес для исследования, так как данный автор намеренно выступает только в жанре фельетона. При этом редакции журналов «Собеседник», «Огонек», «Профиль» регулярно публикуют материалы Дмитрия Быкова, написанные в других жанрах (комментарии, статьи и т. д.). В качестве объекта исследования были выбраны фельетоны данного автора, напечатанные в «Новой газете» в 2012 и 2013 гг. Как показали результаты анализа статистических данных, художественно-публицистические тексты Дмитрия Быкова востребованы на страницах рассматриваемого издания. Так, в 2012 г. в каждом третьем номере газеты вышел фельетон Дмитрия Быкова (71 публикация). В 2013 г. творчество публициста было представлено в каждом четвертом номере (53 материала). Большая востребованность фельетонов в 2012 г. объясняется активизацией политической жизни страны (выборы депутатов Госдумы, президента, митинги на Болотной площади и т. п.).

О том, что фельетоны Дмитрия Быкова позиционируются редакцией и воспринимаются целевой аудиторией как своеобразный бренд «Новой газеты», также свидетельствует выбор места разверстки публикаций в пространстве номера: первая, вторая и последняя полосы, то есть зоны максимального читательского внимания.

В качестве главного оружия борьбы с правительством, чиновниками, полицейским режимом Дмитрий Быков выбирает такой вид фельетона, как памфлет. Его задача заключается в том, чтобы при помощи жесткой критики и осмеяния уничтожать «враждебную» идеологию, политический строй в целом или его отдельные негативные проявления.

Объектом беспощадной критики становится президент страны, депутаты, члены правительства и общественные деятели, ко- торые активно поддерживают курс правительства. Например, отрывок памфлета, в котором высмеиваются поведение депутатов Государственной Думы и Владимира Путина:

Дума окаянная все не перебесится,

Говорят ее разгон - вопрос буквально месяча. О тебе, страдалица, я пишу-корябаю.

Кто бы с кем сравнил, а я сравнил бы с бабою.

С бабой ненасытною, как твои начальники Из таких, какие здесь сажаются на чайники. Взор твой затуманился, разум твой заклинился,

То ли климакс у тебя, а то ли хуже климакса. То с тобой символика, то с тобой истерика, То «МК» твой злейший враг, а то опять Америка,

То распад Миронова, то отель Исаева Чисто ичирк для всей страны, где Путин импресарио (НГ, 2013, № 29).

В данном тексте доминантными воздействующими приемами, работающими на дискредитацию, являются «принижение иронией» и «наклеивание ярлыков», что обусловлено особенностью языковой организации памфлета. Суть приема «принижение иронией» заключается в уничтожении положительного образа объекта описания за счет высмеивания его деятельности или личных качеств, а не приведения конкретных фактов и аргументов.

Комический эффект создается за счет сочетания различных стилевых элементов (сниженный стиль - разговорная и просторечная лексика окаянная, перебесится, корябаю, баба; высокий стиль - страдалииа, взор затуманился, символика, импресарио), а также «травестирования», то есть комической стилизации, которая позволяет журналисту реализовать дискредитацию объекта описа- 
ния, нивелировав серьезность обсуждаемого вопроса.

Травестирование является текстообразующим приемом в фельетонах Дмитрия Быкова, публикующихся в «Новой газете». Практически каждый памфлет оформлен как стилистическое подражание известному для читателей произведению. В ряде случаев Дмитрий Быков специально обозначает прецедентный текст. Так, памфлет с заголовком «Под Кима» начинается с авторской ремарки: На мотив «Губы окаянные», то есть читателю предлагается прямая отсылка к соответствующей песне Юлия Кима.

Имплицитный характер и двуплановость иронии делают ее привлекательной для журналистов. Иронический модус позволяет корреспондентам, во-первых, осмеять противника без выстраивания четкой доказательной базы, во-вторых, обеспечить свою юридическую безопасность (в суде довольно сложно доказать, что ирония используется автором материала с целью умаления авторитета или оскорбления личности).

В основе памфлета лежит открытое и экспрессивное выражение авторских эмоций и оценок. Специфику текстов подобного рода составляет не просто передача информации определенного типа, а стремление повлиять на сознание аудитории таким образом, чтобы оказать воздействие на систему ценностей адресата, скорректировать его мировоззрение. В связи с этим в качестве одной из главных стратегий коммуникации с целевой аудиторией выбирается стратегия самопрезентации.

\section{Стратегия самопрезентации (саморе-} клама) - стратегия, в основе которой лежит интенция, направленная на формирование благосклонности со стороны адресата коммуникации, повышения авторитета конкретного журналиста, статуса редакции издания. Мо- тив стратегии - привлечь внимание читательской аудитории и повысить ее уровень доверия к изданию (редакции) за счет демонстрации лояльности, осведомленности и оригинальности подачи информации.

В качестве одного из средств реализации претензий, связанных с оригинальностью подачи информации, Дмитрий Быков выбрал стихотворную форму фельетонов: «Сочинять политические фельетоны в стихах я начал, когда мне надоело делать это в прозе, вероятно, это было как-то связано с отсутствием ротации в русской политике, или с дефицитом живых и ярких персонажей в ней, или с повторяемостью ее событий: как справедливо писал Слуцкий, поэзия делает интересным даже то, что в прозе уже категорически не звучит» [1, с. 5].

Как показал анализ фельетонов Дмитрия Быкова, стратегия самопрезентации чаще всего реализуется при помощи тактик «акцентирование уникальности», «позиционирование журналиста и/или издания в качестве эксперта», «совместное рассуждение с читателем», «соответствие адресату», «создание общности», «актуализация важности и значимости затрагиваемых тем», «перечисление заслуг». Рассмотрим принципы реализации некоторых из них.

Тактика «акцентирование уникальности» - повышение авторитета объекта описания за счет демонстрации его уникальности, проявляющейся в приобретенных качествах, принятых решениях, осуществляемых действиях. Базовым для данной тактики являются приемы «ссылка на уникальный опыт, уникальные знания» и «повышение статуса адресата».

Пример: Ньнче повод непростой и высокий. Тут вот Дугин, например, погрозился, что не будет никаких философий, а останется одно евразийство. Я в восторге от по- 
Вестник Новосибирского государственного педагогического университета

5(21)2014 www.vestnik.nspu.ru ISSN 2226-3365

добных эдиктов и других его мыслительных взбрыков. Все мертвы, он говорит: Венедиктов, Шендерович, Березовский и Быков... Березовский, разумеется, помер. Но ведь Дугин вообще не рождался! Чтоб на трупе он моем не резвился, предаваясь непристойному лаю, - я хотел бы объяснить евразийство, потому что я его понимаю. Дугин, кстати, вообще конспиролог, любит термины, читает Эволу (или Эволу, такой изотерик, часто с Юнгером его поминают)... Главный враг наш, разумеется, Запад (да кого ж они придумают кроме?): он нас хочет разделить и захапать. "Он не дремлет, мать его, он на стреме» ${ }^{1}$ (ссылки даются в тексте фельетона. - И. К.)... Как до вошки низвести человека с понтом мистика и статью эксперта - объяснил еще догадливый Эко, из Италии, который Умберто ${ }^{2} \ldots$

А соратникам, друзьям и подругам $\boldsymbol{я}$ отвечу с легкомыслием юным: если начал хоронить меня Дугин - жить мне, видимо, не меньше, чем Юнгер ${ }^{3}$. (НГ, 2013, № 24)

На первый взгляд, в адресных фельетонах Дмитрия Быкова оценка превалирует над фактами, а в качестве основного объекта описания выступает сам автор или лирический герой (своеобразный лингвистический аватар, представленный не только в тексте, но и визуально как аватарка, разверстанная в материале вместо фотографии автора). При этом лирический герой (преобладает повествование от первого лица) занимает собой все пространство текста и постоянно подчеркивает свою уникальность: наличие богатого жизненного опыта (я хотел бы объяснить евразийство, потому что я его понимаю),

\footnotetext{
${ }^{1}$ Галич, если кто не узнал.

2 «Вечный фашизм» - см., например, http:// www.nationalism.org/library/science/idelogy/ eco/eco-ur.html

3 Эрнст Юнгер прожил 103 года.
}

эрудированность (или Эволу, такой изотерик, часто с Юнгером его поминают; объяснил ещуе догадливый Эко, из Италии, который

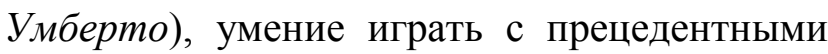
текстами (Oн не дремлет, мать его, он на стреме - отрывок из песни Александра Галича), стилизовать свой фельетон под поэтические произведения других авторов и т. д.

Эксплуатация гипертрофированного авторского «Я» (Я в восторге; на трупе он моем не резвился; я хотел бы объяснить евразийство, потому что я его понимаю; я отвечу) позволяет создать текст, способствующий аттракции. Следовательно, журналист осознанно идет на нарушение постулата скромности и принципа объективности подачи информации, так как преследует цель повысить уровень своего авторитета и представить свою точку зрения как правильную и верную, при этом доказательная база в материале, как правило, отсутствует.

В процессе создания текстов Дмитрий Быков ориентируется на двойную целевую аудиторию. К первой относятся люди, входящие в «страту уличной оппозиции», то есть не обладающие соответствующим уровнем информированности о событиях, происходящих в политической, экономической и социальной сфере. Данная категория читателей воспринимает буквальный пласт сообщаемого, а также авторские эмоции и прямые оценки (остроумные замечания, сатирические ремарки, языковую игру на грани фола) например: Целование начальника в Опу - это истинная суть евразийства. А в прочессе целования в Onы впору вырваться такому экстазу, что мельчающие Штаты-Европь не почувствуют такого ни разу. Облизать ее, верховнылм в угоду, в соответствии с древнейшим заветом, и пожертвовать побольше народу, изнасиловав попутно при этом (НГ, 2013, № 24). 
Языковая игра реализована за счет замены грубого элемента устойчивого выражения со значением «прогибаться перед кем-то, заискивать» фонетическим эвфемизмом «Опа». Значение бранного слова восстанавливается из контекста (целование начальника в, облизать ее, изнасиловав попутно). Воздействующим потенциалом обладает не только подбор соответствующих лингвистических средств, но и особенность графического оформления текста (поэзия представлена как проза), которая позволяет создать эффект неожиданности и переключить внимание читателя с содержания материала на его форму.

Ко второй категории читателей, которые составляют ядро целевой аудитории «Новой газеты», относятся зрелые интеллигентные люди с широким кругозором и сформированной жизненной позицией. Высокий уровень информированности и эрудированности позволяет им обнаружить в тексте ссылки на конкретные факты и события, прецедентные тексты, а также правильно их интерпретировать.

Дмитрий Быков эффективно устанавливает контакт с обоими типами адресатов и включает их в состав «своей референтной группы» при помощи приема «игра на повышение статуса адресата». Его суть заключается в апелляции к положительному образу читателя, который связан с разделением определенной точки зрения или обладанием более высоким уровнем информированности (расшифровка исторических и литературных аллюзий). При этом для первого типа читателей автор фельетонов предлагает систему ссылок и сносок, что также работает на повышение его авторитета и статуса.

Широту своих знаний, незаурядные литературные способности, умение экспериментировать Дмитрий Быков демонстрирует и за счет включения эпиграфов к своим тек- стам. Так, фельетон «Метемпсихическое» предваряется первым и последним четверостишием из произведения Николая Гумилева «Персидская миниатюра». При этом автор «Новой газеты» графически трансформирует стихотворение Гумилева, превращая его в прозу: Когда я кончу наконеи игру в сасhесасhе со смертью хмурой, то сделает меня творец персидскою миниатюрой. И вот когда я утолю, без упоенья, без страданья, старинную мечту мою будить повсюду обожанье (НГ, 2013, № 32).

В тексте самого фельетона также представлена языковая и контекстуальная игра, объектом которой становится эпиграф (в роли объекта обожания выступает доллар, в качестве которого хотел бы реинкарнироваться лирический герой): В России я хотел бы быть деньгами... При первой же опасности меня немедленно б отсюда уводили. Я б побывал во всех концах земли, мои купюры всюду бы налипли - в Швейцарии я был бы, на Бали, но большей частью был бы я на Кипре! Прекрасный остров, теплая вода, ни скучных зим, ни пролетариата... Меня бы не вернули никогда: замучаетесь пыль глотать, ребята. Сам Путин помогать родной стране считает лишним: все глупь и серы... Но если чтото угрожает мне - он принимает экстренные меры!! (НГ, 2013, № 32).

В основе тактики «позиционирование журналиста и/или издания в качестве эксперта» лежит презентация газеты как безусловного авторитета, а корреспондентов как профессионалов и специалистов высокого класса. Дмитрий Быков позиционируется как эксперт в разных сферах: политики, философии, литературы.

Так, на обложке 101-го номера за 2013 г., посвященного подведению итогов выборов мэра Москвы, Быков выступает в 
Вестник Новосибирского государственного педагогического университета

5(21)2014 www.vestnik.nspu.ru ISSN 2226-3365

качестве политолога, который в поэтической форме оценивает результаты голосования:

Второй,

Особо себя не мучая,

Считает все это игрой

Случая.

Банальныий случай

простой авось:

Он явно лучший,

но не склалось (НГ, 2013, № 101).

В ряде публикаций в качестве информационного повода для написания материала выступает момент консультирования у Дмитрия Быкова как литературоведа. Например, адресный фельетон, героем которого стал писатель Михаил Шишкин, трижды лауреат премии «Большая книга»: Коллеги спросили, восторг затая и эхо скандала заслыша: чего, мол, о Шишкине думаю я? Все правильно делает Миша. Он классный писатель, и все его пять романов - ажурное чудо; он вправе, я думаю, сам выбирать, куда приезжать и откуда. Теперь он у всех на устах и в ушах, на Западе час его пробил, он к Нобелю сделал решительный шаг, и это заслуженный Нобель. Теперь для потомства, чей близится суд, он будет безгрешнее Папы, а мы, кто остался при Путине тут, выходит, конечно, caтрапь. Историки, нас извлекая из тьмы, решат в замешательстве тихом, что Шишкин с режимом боролся - а мы глотали икру по Барвихам (НГ, 2013, № 101).

Тактика «совместное рассуждение» заключается в том, что журналист создает у читателя иллюзию паритетного общения и предлагает совместно искать ответы на поставленные им же вопросы. В основе данной тактики лежат такие приемы, как «амальгирование», «интимизация», «намек».

Прием «амальгирование» базируется на создании эффекта единения адресанта и адресата коммуникации за счет формирования «мы-дискурса». В качестве языковых средств реализации данного приема выступают инклюзивные местоимения «мы», «наш», которые являются знаками интеграции, позволяющими создать эффект коллективного отправителя сообщения, в качестве которого выступает журналист и целевая аудитория издания.

Также прием «амальгирование», базирующийся на употреблении местоимения «мы» или других номинаций, в семантике которых содержится значение коллективности и общности (народ, граждане, братья), позволяет журналистам автоматически превращать читателей в своих единомышленников. Пример: Все обсуждают выбор Нобеля - он наградил Евросоюз. Кому бы, впрочем ни дано было - мы б не одобрили, боюсь. Что вы от ярости икаете? Поймите, выбор не богат. Могли б и вовсе дать «Аль-Каиде», ведь получал же Арафат! < ... > Вопрос: не наградить Кадырова ли? Но как-то премия мелка. Она для либералов долбаных, кого давно пора давить; вы, что ли, миллионом долларов его хотите удивить? Так я уже, признаться, думаю, что на чеченском рубеже входить к нему с такою суммою - неуважение уже. $\mathbf{M b l}$ лучше наградим Навального: он был для жителей Кремля предметом ужаса повального еще с начала февраля <...> А в общем, братья бледнолицые, годимся мы по всем мастям. Вручайте приз хоть оппозичии, хоть оседлавшим всех властям... (НГ, 2012, № 39).

В тексте намеренно сталкивается несколько значений местоимения мы: 1) актуальное «мы», под которым подразумевается корреспондент и редакция материала, а также корреспондент и целевая аудитория издания (функция солидаризирования); 2) общенациональное «мы» (граждане Российской Федерации, народ). Это позволяет не только установить контакт с адресатом коммуникации, 
но и представить авторскую точку зрения как поддерживаемую редакционным коллективом и разделяемую всеми, кто относит себя к категории «российские граждане», то есть большинством.

Прием «интимизация» - создание иллюзии дружеского общения (субъектсубъектных отношений), обсуждения «на равных» проблем различной тематической направленности. Журналист формирует образ читателя, якобы обладающего не меньшим житейским опытом и уровнем информированности о происходящих событиях.

Часто Дмитрий Быков создает иллюзию дружеского разговора или исповеди читателю. Таким образом снимается категоричность заявлений, относящихся к саморекламе и самопохвале, например:

Я и сам из этой породьл.

Подобен я крылатому змею.

Некому из ныне живущих

Оченивать, что я умею.

Живу, как сверкающий осколок

Чьего-то грядущего единства,

Какому бы мой дар бесполезный

Когда-нибудь потом пригодился:

Способность притягивать немилость,

Искусство отыскивать подобных,

Талант озадачивать безмозгльх,

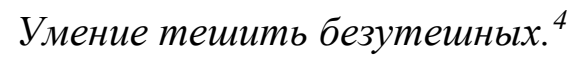

4 Эти неполитические стихи сочинены от нечего делать в Следственном комитете в ожидании жены, которую вызвали на дорос по делу об оскорблении Мизулиной. Я решил, что отпускать жену на допрос одну как-то неправильно. В Следственном комитете пошли мне навстречу, разрешили войти и подождать в коридоре. Выражаю искреннюю благодарность, в том числе и за стихи, которые без этого, конечно, не были бы написаны.
Для снижения категоричности авторского повествования, а также создания эффекта объективного и непредвзятого исследования действительности Дмитрий Быков использует прием «намек» - способ выражения авторской мысли, которая зашифрована в подтексте. Чтобы понять суть высказывания, читатель должен обратиться к своему жизненному опыту. Главным средством создания намека является приватизация знаний (создание иллюзии, что смысл высказывания читатель понимает сам, тогда как автор подводит его к определенной мысли).

Пример: Ещче одна черта - смотри, любуйся, - наглядна, как пятно на простынях: есть буйство с разрешения на буйство, как это называет Пастернак. Им близко чувство локтя, свары, своры, им нравится, конечно, бить под дых - но лучше б инвалида. Бузотеры, но только с разрешенья всех святых, как молвил Мандельштам в «Четвертой прозе». Они и сами сыты и крепки, но при любой помстившейся угрозе бегут под сень спасительной руки (НГ, 2012, № 8).

В данной публикации «намек» основан на подаче имплицитной информации за счет создания импликатуры. Импликатуры смысловые лакуны, при которых адресат, стремящийся к осмыслению воспринимаемого текста как связанного, оказывается вынужденным неосознанно восполнять его суждениями, соответствующими невысказанной (поскольку она якобы очевидна) точке зрения говорящего [7].

Автор памфлета актуализирует в сознании читателя негативные явления, связанные с вседозволенностью, и ангажированность сотрудников полиции (разгон марша несогласных, избиение участников митинга на Болотной), тоталитарностью власти. При помощи приема «визуализация» (материал разверстан на фотографии Владимира Путина с 
поднятой рукой) обозначается главный виновник репрессивных мер (бегут под сень спасительной руки), хотя в самом тексте данный политик вообще не упоминается.

Прием «намек» имеет двойную направленность. Во-первых, адресант коммуникации остается в зоне этической и юридической безопасности, так как использует форму скрытой критики. Во-вторых, намек позволяет создать у читателя иллюзию самостоятель- ности в понимании и интерпретации смысла отдельного высказывания и текста в целом.

Таким образом, сочетание в тексте различных способов самопрезентации позволяет журналисту не только повысить собственный статус и стать своеобразным брендом издания, но и оказывать эффективное воздействие на сознание и восприятие окружающей действительности различными категориями читателей.

\section{СПИСОК ЛИТЕРАТУРЫ}

1. Быков Д. Л. Новые и новейшие письма счастья. - М.: Время, 2012. - 512 с.

2. Желтухина М. Р. Тропологическая суггестивность масс-медиального дискурса: о проблеме речевого воздействия тропов в языке СМИ. - М.: Институт языкознания РАН, 2003. - 654 с.

3. Костомаров В. Г. Языковой вкус эпохи. Из наблюдений за языковой практикой масс-медиа. СПб.: Златоуст, 1994. - 319 с.

4. Соков А. И. От заметки до фельетона. - Новосибирск: Новосибирский полиграфкомбинат, 2005. - 141 c.

5. Солганик Г. Я. О закономерностях развития языка газеты в XX веке // Вестник Московского университета. Сер. 10. Журналистика. - 2002. - № 2. - С. 39-53.

6. Тепляшина А. Н. Жанры и формы комического в современной российской периодике. СПб.: СПбГУ, 2006. -286 с.

7. Федосюк М. Ю. Выявление приемов «демагогической риторики» как компонент полемического искусства // Риторика в развитии человека и общества. - Пермь: ЗУУНЦ, 1992. C. 94-99. 
DOI: $10.15293 / 2226-3365.1405 .20$

Kateneva Irina Gennadjevna, Candidate of Philology Sciences, associate Professor of the Department of Journalism, Novosibirsk State Pedagogical University, Novosibirsk, Russian Federation.

E-mail: irina-kateneva@yandex.ru

\title{
METHODS OF SELF-PRESENTATION IN MASS MEDIA TEXTS BY DMITRY BYKOV (ON MATERIALS OF THE “NEW NEWSPAPER")
}

\begin{abstract}
The revival of interest in artistic and journalistic genres is one of the tendencies of development of modern journalism. Thus newsmen can use variety resources of influence on target audience. This article is devoted to the investigation of some methods of self-presentation in Mass-media texts. The object of the study is the satirical articles by Dmitry Bykov, which are the materials of the social and political newspaper "New newspaper" for the years 2012 and 2013. Dmitry Bykov writes only satirical articles for this newspaper. These publications are brand for the editorial staff and readers. In this regard, the self-presentation is the main communication strategy. The communication tactics, techniques and language resources providing the self-presentation are analyzed in detail. In conclusion, it is reported that a combination of text in different ways of self allows the journalist not only elevate their status and become a kind of brand publications, but also an effective impact on the consciousness and perception of reality different categories of readers.
\end{abstract}

\section{Keywords}

methods of self-presentation, communication tactics and techniques, satirical article, oppositional newspaper

\section{REFERENCES}

1. Bykov D. L. New and newest letters of happiness. Moscow, Time Publ., 2012. 512 p. (In Russian)

2. Zheltuhina M. R. Exposure potential means of expression in mass media texts: the problem of speech influence of the means of expression in language of mass media. Moscow, Institute of Linguistic Russian Academy of Sciences Publ., 2003. 654 p. (In Russian)

3. Kostomarov V. G. Language taste of epoch. From the observation of linguistic practice of mass-media. Saint-Petersburg, Zlatoust Publ., 1994. 319 p. (In Russian)

4. Sokov A. I. From the notes to the feuilleton. Novosibirsk, Novosibisk Polygrafkombinat Publ., 2005. 141 p. (In Russian)

5. Solganik G. Y. On regularities of the development of the language newspaper in the twentieth century. Bulletin of Moscow state University. Series 10. Journalism, 2002, no. 2, pp. 39-53. (In Russian)

6. Teplyashina A. N. Comic genres and forms in the text of modern Russian newspapers and magazines. Saint-Petersburg, Saint-Petersburg University Publ., 2006. 286 p. (In Russian)

7. Fedosyuk M. Y. The techniques of «demagogical rhetoric» as a component of polemical art. The rhetoric in the development of man and society. Perm, West Ural Training and Research Centre Publ., 1992. pp. 94-99. (In Russian) 


\section{К СВЕДЕНИЮ АВТОРОВ ЖУРНАЛА}

Научный журнал «Вестник Новосибирского государственного педагогического университета» - электронное периодическое издание, учрежденное ФГБОУ ВПО «Новосибирский государственный педагогический университет», в котором публикуются ранее не опубликованные статьи, содержащие основные результаты исследований в ведущих областях научного знания.

Материалы статей, подготовленные автором в соответствии с правилами оформления регистрируются, лицензируются, проходят научную экспертизу, литературное редактирование и корректуру.

Решение о публикации принимается редакционной коллегией и редакционным советом электронного журнала.

Регистрация статьи осуществляется в on-line режиме на основе заполнения электронных форм. По электронной почте статьи не регистрируются.

Редакционная коллегия электронного журнала оставляет за собой право отбора присылаемых материалов. Все статьи, не соответствующие тематике электронного журнала, правилам оформления, не прошедшие научную экспертизу, отклоняются. Корректура статей авторам не высылается.

Тексты статей необходимо оформлять в соответствии с профессиональными требованиями к научной статье, объемом в пределах половины печатного листа (20000 знаков).

Публикуемые сведения к статье на русском и английском языках:

$>$ заглавие - содержит название статьи, инициалы и фамилию автора/ авторов, город, страна, а также УДК;

$>$ адресные сведения об авторе - указывается основное место работы, занимаемая должность, ученая степень, адрес электронной почты для связи;

$>$ аннотация статьи (от 1000 знаков) - отражает ее основное содержание, обобщающие результаты и ключевые слова;

$>$ пристатейный список литературы - оформляется в соответствии с требованиями ГОСТ Р 7.0.5-2008; формируется в соответствии с порядком упоминания в тексте статьи; регистрируется ссылкой (ссылки в тексте оформляются в квадратных скобках, содержат порядковый номер в списке литературы и страницы цитируемой работы).

Одновременно с направлением в редакцию журнала текста статьи, подготовленного для публикации, автору необходимо выслать сопроводительные документы к статье, оформленные в соответствии с требованиями.

Сопроводительные документы к статье:

$>$ оригинал развернутой рецензии направляющей организации / научного руководителя / специалиста по теме публикации (с подписью и печатью);

$>$ авторский лицензионный договор.

Подробно с правилами публикации можно ознакомиться на сайте журнала:

http://vestnik.nspu.ru/avtoram 


\section{FOR AUTHORS. THE INFORMATION ABOUT THE ORDER OF PUBLICATION OF ARTICLE}

The scientific journal «Novosibirsk State Pedagogical University Bulletin» is electronic periodical founded by Novosibirsk State Pedagogical University. Journal articles containing the basic results of researches in leading areas of knowledge were not published earlier.

The materials of articles, carefully prepared by the author, are registered, are licensed, materials are scientific expertise, literary editing and proof-reading.

The decision about the publication is accepted by an editorial board and editorial advice of electronic journal.

Also it is displayed in personal "cabinet" of the author.

Registration of article is carried out in on-line a mode on the basis of filling electronic forms e-mail articles are not registered.

The Editorial Board of the electronic journal reserves the right to itself selection of sent materials. All articles are not relevant to the content of electronic magazine, to rules of the registrations rules that have not undergone scientific expertise, are rejected. The proof-reading of articles is not sent to authors. Manuscripts are not returned.

Texts of articles are necessary for making out according to professional requirements to the scientific article, volume within the limits of 0,5 printed page (20000 signs).

Published data to article in Russian and English languages:

the title - contains article name, the initials and a surname of authors / authors, the city, the country, and also UDC;

address data on the author - the basic place of work, a post, a scientific degree, an e-mail address for communication is underlined;

the abstract (100-250 words) - reflects its basic maintenance, generalizing results and keywords;

the references - is made out according to requirements of GOST P 7.0.5-2008; it is formed according to order of a mention in the text of paper; it is registered by the reference (references in the text are made out in square brackets, contain a serial number in the References and page of quoted work).

Simultaneously with a direction in edition of electronic journal of the text of articles prepared for the publication, it is necessary for author to send accompanying documents to articles, issued according to requirements.

Accompanying documents to article:

the original of the developed review of the directing organization / the research supervisor / expert in a publication subject (with the signature and the press);

author's license contract.

In detail the rules of the publication on the site of journal:

http://en.vestnik.nspu.ru/avtoram 